LUCIA MIDORI NAKAZONE

\title{
IMPLANTAÇÃO DE RESERVATÓRIOS DE DETENÇÃO EM CONJUNTOS HABITACIONAIS: A EXPERIÊNCIA DA CDHU
}

Dissertação apresentada à Escola

Politécnica da Universidade de São

Paulo para obtenção do Título de

Mestre em Engenharia.

v. 1

São Paulo

2005 
LUCIA MIDORI NAKAZONE

\title{
IMPLANTAÇÃO DE RESERVATÓRIOS DE DETENÇÃO EM CONJUNTOS HABITACIONAIS: A EXPERIÊNCIA DA CDHU
}

\author{
Dissertação apresentada à Escola \\ Politécnica da Universidade de São Paulo \\ para obtenção do Título de Mestre em \\ Engenharia. \\ Área de concentração: \\ Engenharia Hidráulica \\ Orientador: \\ Prof ${ }^{\circ}$ Dr. Rubem La Laina Porto
}

São Paulo 
Este exemplar foi revisado e alterado em relação à versão original, sob responsabilidade única do autor e com a anuência de seu orientador.

São Paulo, 13 de fevereiro de 2006.

Assinatura do autor

Assinatura do orientador

\section{FICHA CATALOGRÁFICA}

Nakazone, Lucia Midori

Implantação de reservatórios de detenção em conjuntos

habitacionais: a experiência da CDHU / L.M.Nakazone. - São

Paulo, 2005.

305p.

Dissertação (Mestrado) - Escola Politécnica da Universidade de São Paulo. Departamento de Engenharia Hidráulica e Sanitária.

1.Drenagem urbana 2.Inundações(Controle) 3.Água Pluvial 4.Reservatórios I.Universidade de São Paulo. Escola Politécnica. Departamento de Engenharia Hidráulica e Sanitária II.t. 
"A água é uma fonte de vida, energia, conforto e prazer, um símbolo universal de purificação e renovação. Como um imã primordial, atrai uma parte primitiva e bastante profunda da natureza humana. Mais do que qualquer outro elemento, além das árvores e dos jardins, tem o potencial de forjar um elo emocional entre o homem e a natureza na cidade. Pura, no lugar certo e no tempo certo, a água é um recurso essencial; contaminada e no lugar e tempo errados, é uma ameaça à vida." 


\section{AGRADECIMENTOS}

Ao meu orientador $\operatorname{Prof}^{\circ}$ Dr. Rubem La Laina Porto pela extrema paciência, sensibilidade e incentivos na busca de novos caminhos.

A CDHU pela oportunidade e inspiração.

Ao eng ${ }^{\circ}$ Vinicius Camargo Barbeiro e ao Prof ${ }^{\circ}$ Dr. Luiz Antonio Pereira de Oliveira por acreditarem na minha capacidade.

Aos meus professores pela generosidade de seus conhecimentos, e em especial, aos professores Mônica Ferreira do Amaral Porto, Kamel Zahed Filho e Kokei Uehara pelos incentivos.

A arqt $^{\mathrm{a}}$ Ana Maria Antunes Coelho, a eng ${ }^{\mathrm{a}}$ Heloísa Assumpção e a eng ${ }^{\mathrm{a}}$ Mirléia Carvalho por compartilharem suas experiências e opiniões.

A Iara Bueno, Iara Silva Serafim e Satie Ishikawa pelo constante apoio e colaboração.

Aos meus pais e irmãos por colaborarem na minha formação e ao meu pequeno sobrinho César.

A todos os meus amigos, presentes ou a distância, pelo imenso carinho, compreensão e apoio. 


\section{RESUMO}

O aumento das inundações é ainda um desafio a ser superado, principalmente em áreas densamente urbanizadas. O convívio com os eventos de cheias tem se tornado ao longo do tempo, cada vez mais freqüente e intolerável, trazendo constantes riscos de perdas humanas e a ampliação dos prejuízos econômicos. Novas medidas de controle das vazões excedentes surgiram nos últimos anos e buscam contornar as mudanças nos ciclos hidrológicos, imitando e mantendo as condições naturais existentes antes dos processos de urbanização. Uma dessas alternativas, conhecida genericamente pelo nome de reservatório de armazenamento, procura reter parte do escoamento superficial gerado durante as precipitações, para depois fazer sua devolução de forma lenta e gradual aos leitos dos córregos e rios, atenuando o pico dos hidrogramas e redistribuindo as vazões ao longo do tempo. Uma das variáveis desse reservatório de armazenamento, que permanece seco entre eventos chuvosos, é denominado de reservatório de detenção e constitui-se o objeto deste trabalho. Sua implantação e utilização são discutidas por meio das experiências da CDHU, através de estudos de casos reais, onde prova-se que a incorporação desse novo dispositivo de drenagem urbana é ainda um assunto polêmico, para o qual técnicos, governantes e população estão despreparados. É legítimo o anseio da sociedade por medidas sustentáveis e ambientalmente corretas, na qual os reservatórios de detenção se enquadram, porém sua implementação por força de medidas legais, muitas vezes, tem sido realizada de forma pouco consequiente, sem planejamento e ponderação quanto às dificuldades e implicações dessa atitude. Denota-se também, a necessidade de avaliação da eficiência destes dispositivos e de normatização das formas de aplicação, dimensionamento, operação e manutenção. Além disso, é necessário a sensibilização, a conscientização e a educação em todos os níveis, pois existem paradigmas a serem quebrados e obstáculos a serem vencidos. Ao final do trabalho, sugere-se um pequeno roteiro com diretrizes gerais para incorporação dos reservatórios de detenção em novos empreendimentos, com o intuito de orientar e facilitar a utilização desses dispositivos, melhorando sua aceitação pela sociedade. 


\begin{abstract}
The increasing of floods magnitude and frequency is a challenge to overcome, specially in densely urbanized areas. Along the time, living with this kind of event has become much more intense and intolerable, due to the constant risks of human losses and the amplification of economic damages. New stormwater control techniques have emerged during last years, trying to mimic and keep the natural conditions of hydrologic cycle. One of these measures, known as storage facility, detains part of the rainfall runoff to release it at controlled rates downstream, attenuating the hydrograph peak and redistributing the volume over a certain period of time. The focus of this report is the detention basin, a storage facility designed to empty out between runoff occurrences. Its insertion and use are discussed through CDHU experiences, based on real cases, where the results show that this new urban drainage control system is still a polemic issue, for what technicians, governments and population are unprepared. Society's concerns about sustainable and environmentally correct measures, inside which detention pond is placed, are rightful, however its implementation in the course of legal procedures has been made carelessly, unplanned and without considerations of difficulties and impacts. In addition, evaluation of its performance along with regulation of using forms, dimensioning, operation and maintenance are also required. Moreover, sensitiveness, consciousness and education related to detention basin should be improved, since there are paradigms to be broken and obstacles to win. At the end of this report, it is suggested some guidelines to incorporate detention basins in new land development, not only to facilitate and instruct the use of this structure, but also to improve society's acceptance.
\end{abstract}




\section{SUMÁRIO}

\section{LISTA DE FIGURAS}

LISTA DE TABELAS

LISTA DE ABREVIATURAS E SIGLAS

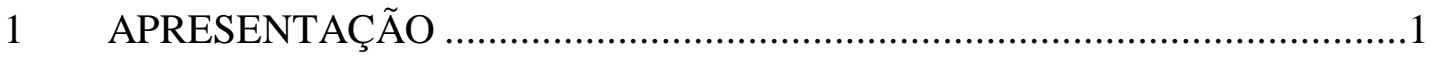

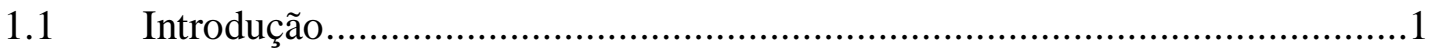

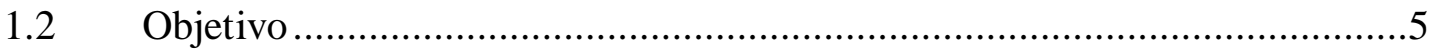

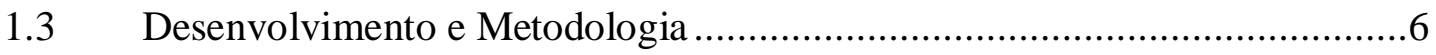

2 INUNDAÇÕES URBANAS ...........................................................

2.1 Classificação das Inundações e a Influência da Urbanização ......................11

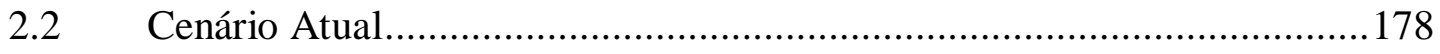

2.3 Medidas de Controle de Cheias Urbanas ................................................23

2.3.1 Classificação das medidas de controle ...................................................25

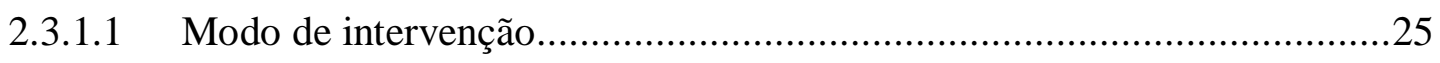

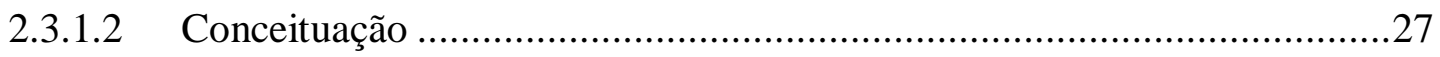

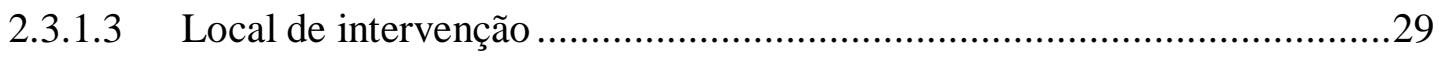

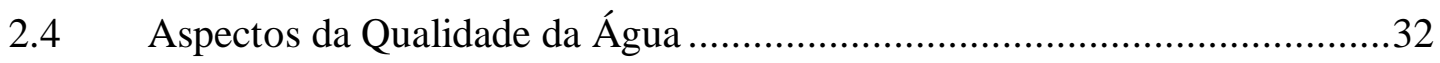

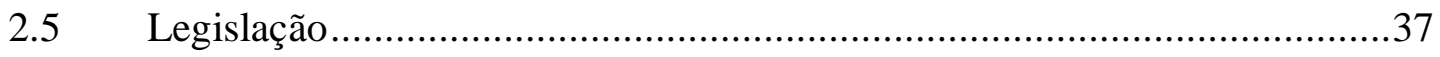

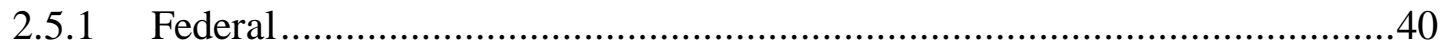

2.5.1.1 Constituição da República Federativa do Brasil.....................................40

2.5.1.2 Política Nacional de Recursos Hídricos e Sistema Nacional de

Gerenciamento de Recursos Hídricos ................................................................42

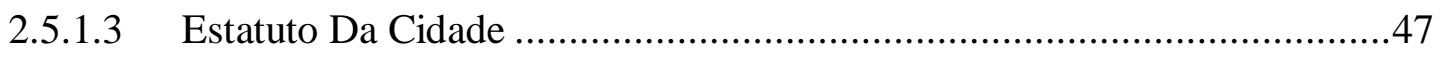

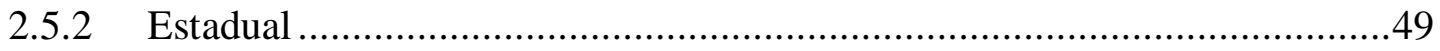

2.5.2.1 Constituição do Estado de São Paulo......................................................49

2.5.2.2 Política Estadual de Recursos Hídricos e Sistema Integrado de

Gerenciamento de Recursos Hídricos do Estado de São Paulo................................52

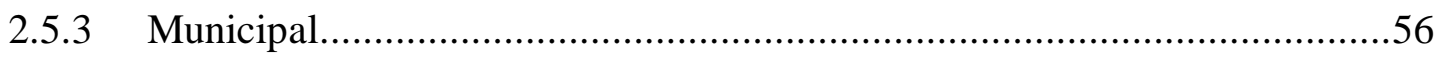




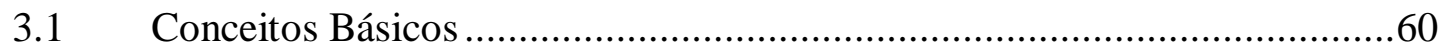

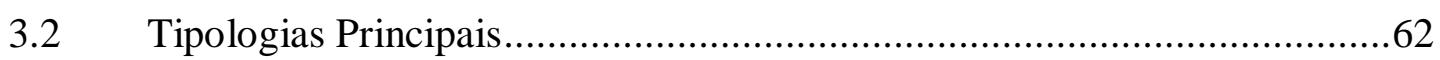

3.2.1 Reservatórios de armazenamento e controle de cheias ..............................63

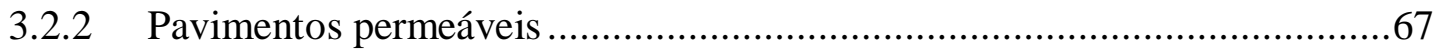

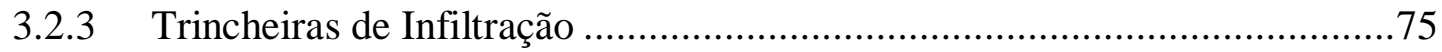

3.3 Ferramentas de Avaliação e Seleção.......................................................79

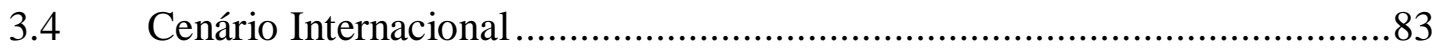

3.4.1 Evolução das medidas de controle de cheias.............................................83

3.4.1.1 Melhores Práticas de Gerenciamento - BMP ..........................................84

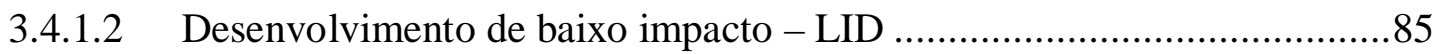

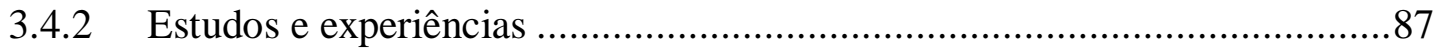

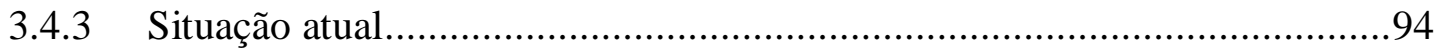

4 RESERVATÓRIOS DE DETENÇÃO .................................................97

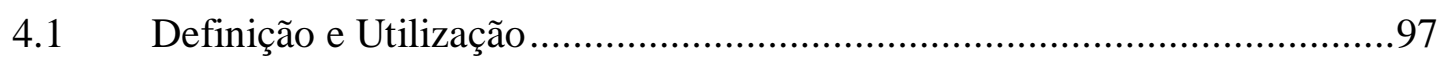

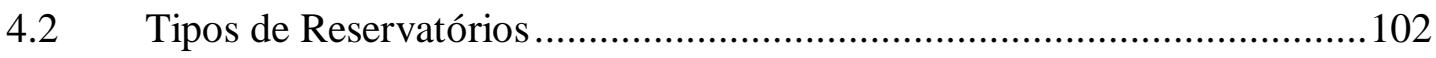

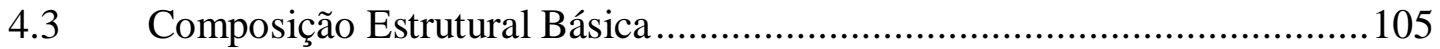

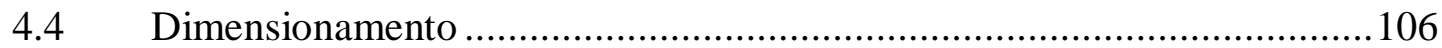

4.5 Vantagens e Desvantagens do Sistema ................................................110

4.6 Estudos e Experiências........................................................................ 112

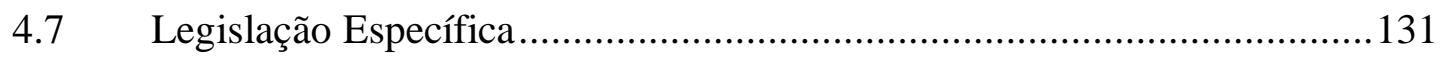

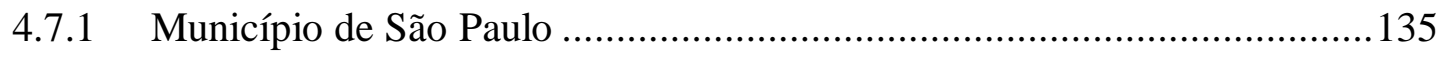

4.7.2 Município de Porto Alegre ...............................................................138

5 COMPANHIA DE DESENVOLVIMENTO HABITACIONAL E URBANO

DO ESTADO DE SÃO PAULO - CDHU ......................................................... 141

5.1 Características da População Beneficiária ................................................ 144

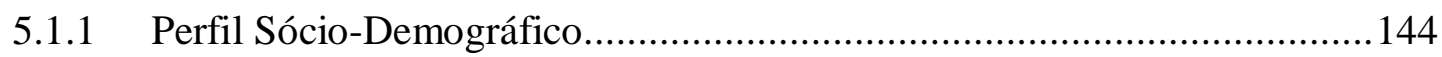

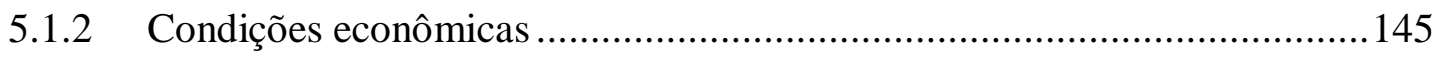

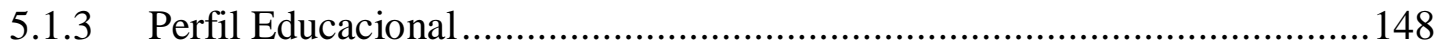

5.2 Filosofia dos Sistemas de Drenagem da CDHU ......................................149 


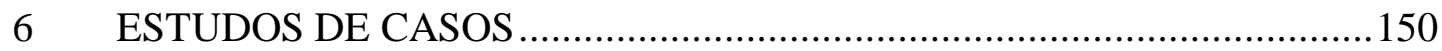

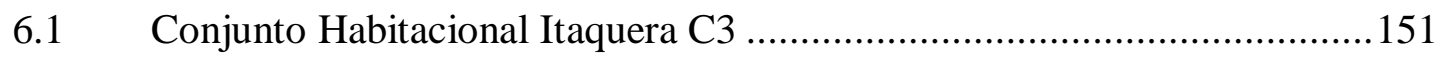

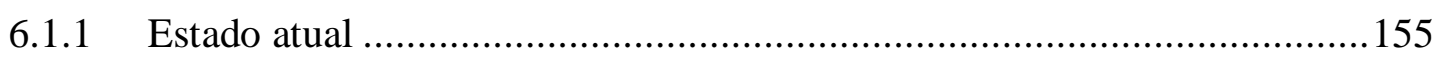

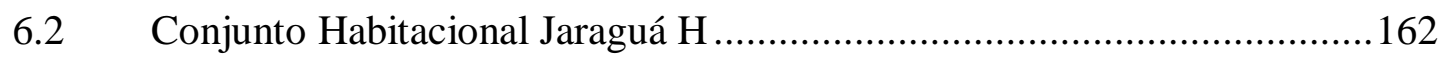

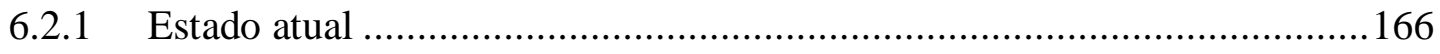

6.3 Conjunto Habitacional Vila Jacuí B1 ....................................................172

6.4 Conjunto Habitacional A.................................................................... 177

6.5 Conjunto Habitacional Herculândia C ......................................................182

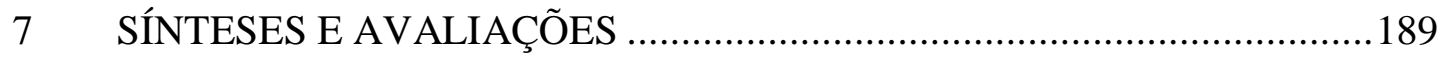

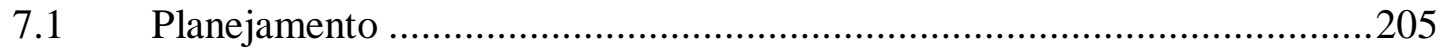

7.1.1 Comitês de bacias hidrográficas .........................................................208

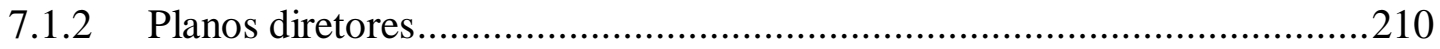

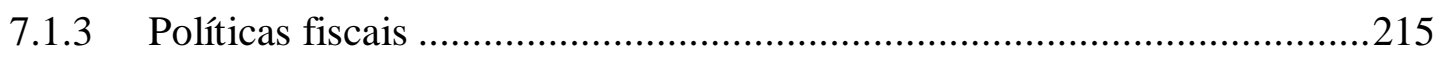

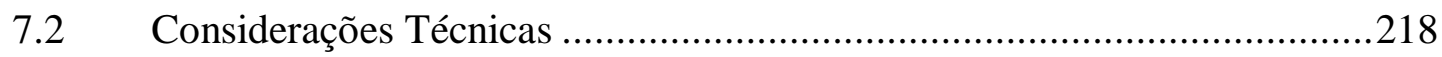

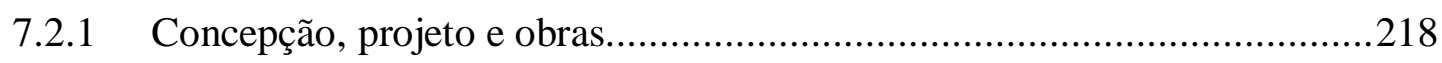

7.2.2 Operação, inspeção e manutenção ......................................................222

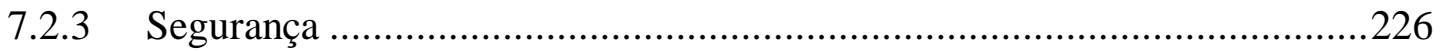

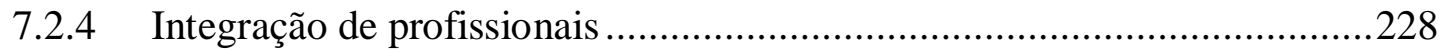

7.2.5 Formação e capacitação do corpo técnico .............................................229

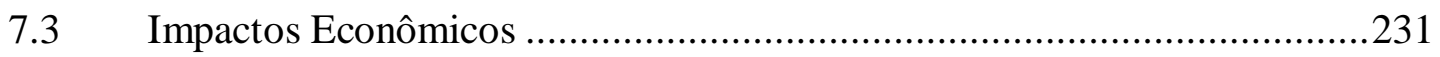

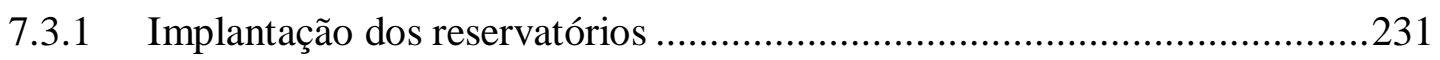

7.3.2 Inspeção, operação e manutenção .......................................................232

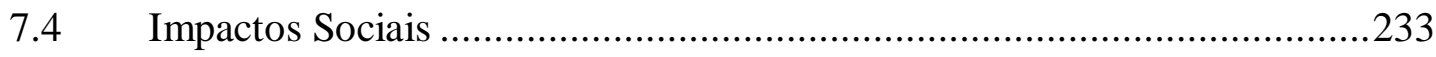

7.4.1 Sensibilização e conscientização .........................................................234

7.4.2 Aproveitamentos múltiplos .............................................................238

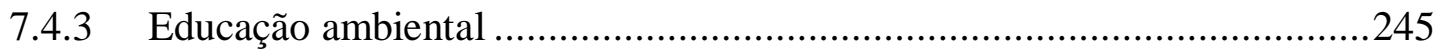

8 DIRETRIZES GERAIS PARA INCORPORAÇÃO DE RESERVATÓRIOS

DE DETENÇÃO EM NOVOS EMPREENDIMENTOS .....................................248

9 CONCLUSÕES E RECOMENDAÇÕES ............................................25 


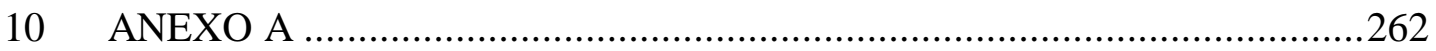

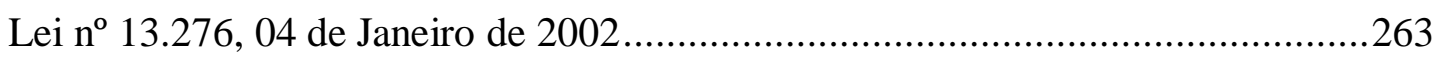

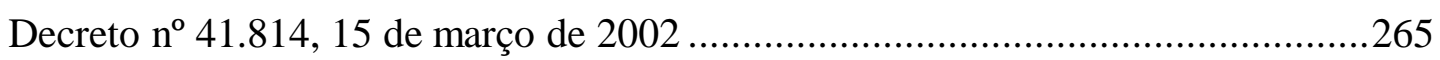

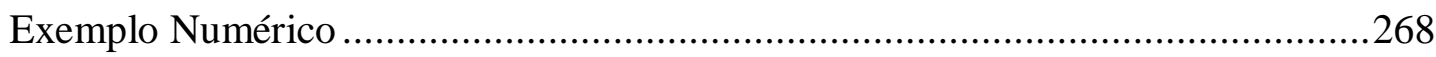

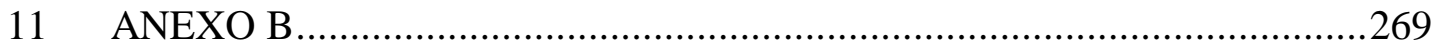

Decreto de Regulamentação Municipal para Controle da Drenagem Urbana Proposto

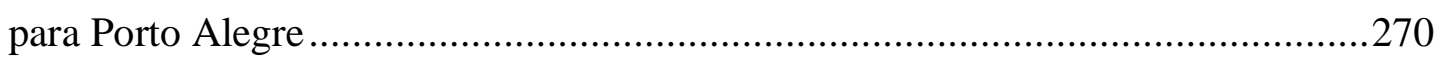

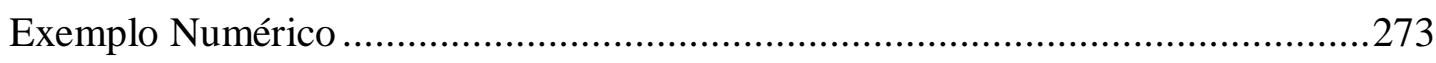

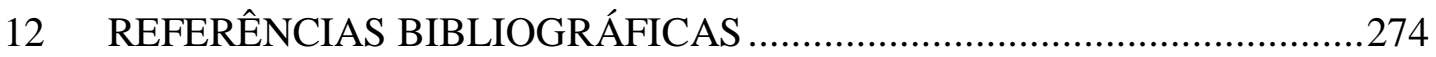




\section{LISTA DE FIGURAS}

Figura 1 - Enchentes na região metropolitana de São Paulo ................................... 10

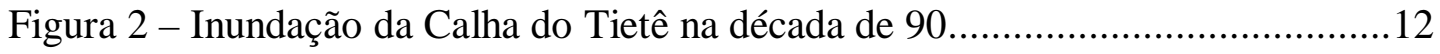

Figura 3 - Ocupação das várzeas pelas cheias e sua recorrência .............................12

Figura 4 - Efeito da urbanização sobre o hidrograma pré-existente.........................13

Figura 5 - Efeito da evolução da urbanização sobre o hidrograma pré-existente ......13

Figura 6 - Efeito da urbanização sobre a vazão máxima de rios urbanos ...................14

Figura 7 - Efeito da urbanização sobre o tempo de concentração ............................14

Figura 8 - Efeito da densidade populacional sobre a área impermeável....................15

Figura 9 - Efeito da área impermeável sobre a variação da temperatura...................15

Figura 10 - Processos que envolvem o desenvolvimento de uma área urbana ..........16

Figura 11 - Rio Vils em Amberg em 1990 e após renaturalização............................20

Figura 12 - Classificação dos dispositivos de armazenamento ................................. 31

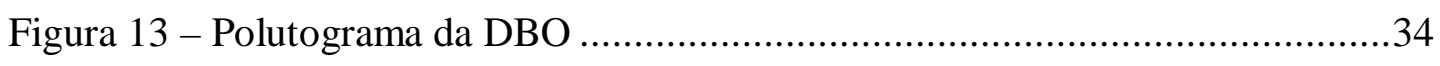

Figura 14 - Reservatório de retenção, Santa Terezinha, 2002 ...............................64

Figura 15 - Extended detention basin (planta) .....................................................65

Figura 16 - Extended detention basin (perfil) .................................................65

Figura 17 - Extended detention basin ..........................................................66

Figura 18 - Tipos de pavimentos permeáveis......................................................68

Figura 19 - Diferença entre pavimento convencional e pavimento poroso ...............69

Figura 20 - Resultado dos escoamentos no solo compactado e nos blocos vazados..70

Figura 21 - Tipos de pavimentos avaliados....................................................... 72

Figura 22 - Escoamento superficial observado por tipo de pavimento......................73

Figura 23 - Esquema típico de uma trincheira de infiltração ....................................75

Figura 24 - Construção de trincheira de infiltração ...................................................77

Figura 25 - Comparação entre concepção convencional e concepção com técnicas de

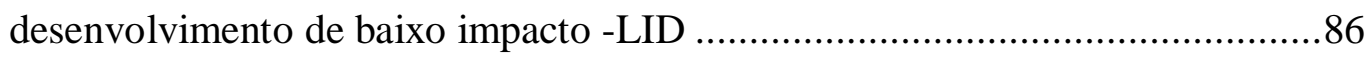

Figura 26 - Sistema valeta - trincheira de infiltração (seção transversal) ..................89

Figura 27 - Sistema valeta - trincheira de infiltração (seção longitudinal) ................89

Figura 28 - Sistema de drenagem de Woodland...................................................92

Figura 29 - Utilização de material reciclado em estruturas alternativas ..................93 
Figura 30 - Evolução do uso dos reservatórios de detenção/retenção .96

Figura 31 - Hidrogramas típicos de bacias de detenção........................................97

Figura 32 - Interação adversa nos hidrogramas de cheias ...................................101

Figura 33 - Hidrograma de reservatório in-line................................................102

Figura 34 - Princípios básicos de funcionamento do reservatório off-line .............103

Figura 35 - Hidrograma de reservatório off-line ............................................... 103

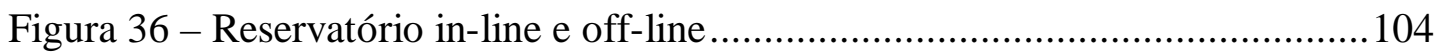

Figura 37 - Volume a ser armazenado pelo reservatório de detenção

Figura 38 - Comparação entre volumes determinados por metodologias diferentes 109

Figura 39 - Aumento da vazão de pico em função da impermeabilização

Figura 40 - Aumento do volume escoado em função da impermeabilização

Figura 41 - Esquema construtivos dos reservatórios

Figura 42 - Esquema construtivos dos reservatórios 1

Figura 43 - Volumes de detenção necessários para lotes em Porto Alegre, com

diferentes taxas de impermeabilização e TR de 5 anos

Figura 44 - Custos de implantação de dispositivos de detenção em lotes 120

Figura 45 - Planta do Conjunto Habitacional Itaquera C3

Figura 46 - Corte e detalhe genérico do reservatório de detenção 154

Figura 47 - Reservatório completamente cheio 155

Figura 48 - Reservatório parcialmente cheio 156

Figura 49 - Motivo da obstrução dos dispositivos 156

Figura 50 - Extravasor com caimento invertido 157

Figura 51 - Execução dos reservatórios de detenção e das caixas coletoras nos estacionamentos 158

Figura 52 - Remoção e recolocação das cercas do empreendimento 158

Figura 53 - Impacto visual dos reservatórios no contexto ambiental interno 160

Figura 54 - Impacto visual dos reservatórios no contexto ambiental externo 161

Figura 55 - Reservatórios ocultos pelos taludes 161

Figura 56 Reservatórios envolvidos pela vegetação............................................162

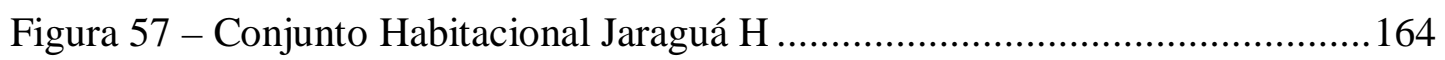

Figura 58 - Posicionamento e detalhamento dos reservatórios..............................165

Figura 59 - Sistemas de drenagem conservados ............................................... 166 
Figura 60 - Infiltrações nas paredes dos apartamentos e dos reservatórios .......

Figura 61 - Registros de gaveta abertos ou parcialmente abertos dos sistemas de descarga dos reservatórios de detenção

Figura 62 - Sistema viário que recebe a água armazenada nos reservatórios

Figura 63 - Tampa de acesso para inspeção existente

Figura 64 - Estacionamento com piso de concreto ao lado dos reservatórios de detenção

Figura 65 - Impacto visual de estacionamentos com piso permeável e impermeável

Figura 66 - Integração dos reservatórios no contexto ambiental...........................171

Figura 67 - Inserção do Conjunto Habitacional Vila Jacui B1 .............................173

Figura 68 - Conjunto Habitacional Vila Jacuí B1 _............................................ 174

Figura 69 - Detalhes das "caixas de retardo" do Conjunto Habitacional Vila Jacuí

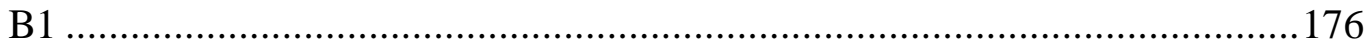

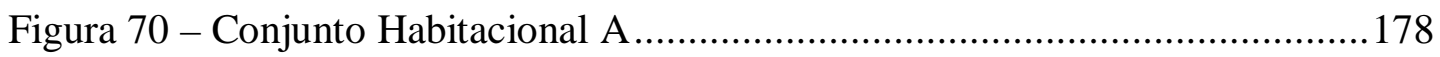

Figura 71 - Vista da área no início da urbanização .............................................179

Figura 72 - Vista da área durante a execução do empreendimento ........................ 179

Figura 73 - Corte transversal de um dos reservatórios .........................................181

Figura 74 - Conjunto Habitacional Herculândia C ................................................183

Figura 75 - Vista geral do Conjunto Habitacional Herculândia C ...........................184

Figura 76 - Vistas parciais das bacias de contribuição..........................................185

Figura 77 - Vista do sistema de lazer e do futuro reservatório ...............................186

Figura 78 - Utilização indevida de ponto de acúmulo de águas pluviais ................227

Figura 79 - Reservatório de detenção criado no recuo frontal...............................240

Figura 80 - Reservatório de detenção em recuo frontal e o dispositivo de saída ....241

Figura 81 - Reservatório de detenção em área de recreação .................................241

Figura 82 - Espaço livre aproveitado para armazenamento de água.......................242

Figura 83 - Armazenamento criado em recuo lateral............................................242 


\section{LISTA DE TABELAS}

Tabela 1 - Causas e efeitos da urbanização sobre as inundações .............................17

Tabela 2 - Municípios atingidos pelas inundações entre 1998 e 1999 ......................18

Tabela 3- Fatores agravantes das inundações.......................................................19

Tabela 4 - Canalização x Armazenamento ........................................................28

Tabela 5 - Matriz de avaliação da eficiência das BMPs ..........................................36

Tabela 6 - Simulações de chuva no solo compactado e nos blocos vazados .............71

Tabela 7 - Resultado das simulações de chuva em diferentes tipos de pavimentos...73

Tabela 8 - Preço de implantação dos pavimentos...................................................74

Tabela 9 - Pesos para aplicação de diferentes medidas de controle ........................79

Tabela 10 - Categorização das características da bacia hidrográfica para análise de aplicabilidade de medidas de controle na fonte ............................................80

Tabela 11 - Ordem de eficiência das BMPs ......................................................81

Tabela 12 - Matriz de avaliação da eficiência das BMPs ....................................82

Tabela 13 - Média superior de volume de um método com relação aos demais......108

Tabela 14 - Reservatório lacrado com 1 m de profundidade ...............................117

Tabela 15 - Reservatório de $1 \mathrm{~m}$ de profundidade com infiltração em solo batido..117

Tabela 16 - Custo de implantação dos reservatórios de 2,0 e 2,5 m ....................118

Tabela 17 - Critérios de projeto para armazenamento de cheias urbanas ................122

Tabela 18 - Resposta ao questionário sobre práticas usuais, opiniões e observações

Tabela 19 - Volume de detenção para controle de cheias em lotes de cidades brasileiras

Tabela 20 - Características e cenários de verificação ..........................................128

Tabela 21 - Dimensões ótimas dos reservatórios.............................................129

Tabela 22 - Déficit e necessidades habitacionais no estado de São Paulo................142

Tabela 23 - Perfil etário da população atendida pela CDHU .................................144

Tabela 24 - Número de indivíduos das famílias atendidas pela CDHU..................145

Tabela 25 - Faixa de renda das famílias cadastradas ............................................146

Tabela 26 - Tipo de ocupação do chefe de família ...............................................146 
Tabela 27 - Percentual de pagantes pelos serviços públicos

Tabela 28 - Comprometimento de renda com custos habitacionais.......................147

Tabela 29 - Perfil educacional da população atendida pela CDHU .......................148

Tabela 30- Síntese da apresentação dos estudos de casos......................................193

Tabela 31 - Características urbanísticas dos empreendimentos.............................194

Tabela 32 - Características físicas dos reservatórios de detenção .........................195

Tabela 33 - Parâmetro e critérios de dimensionamento ........................................196

Tabela 34 - Custos e outras informações.........................................................197

Tabela 35- Situação dos reservatórios de detenção implantados ...........................198

Tabela 36- Questionamentos principais quanto aos reservatórios de detenção:

Planejamento

Tabela 37- Questionamentos principais quanto aos reservatórios de detenção: Projeto e Execução

Tabela 38- Questionamentos principais quanto aos reservatórios de detenção: Falhas Físicas

Tabela 39 - Questionamentos principais quanto aos reservatórios de detenção:

Operação e Manutenção 203

Tabela 40 - Questionamentos principais quanto aos reservatórios de detenção: Meio

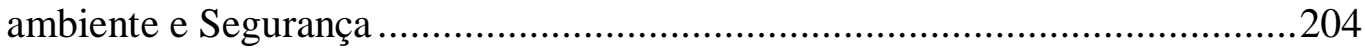

Tabela 41 - Problemas de estrutura organizacional e institucional .......................207

Tabela 42 - Valores médios de áreas livres dos planos diretores .........................212

Tabela 43 - Modalidades de financiamento ........................................................216

Tabela 44 - Avaliação da manutenção, monitoramento e vigilância dos reservatórios

Tabela 45 - Municípios com sistemas de drenagem e tipo de atividade de manutenção 


\section{LISTA DE ABREVIATURAS E SIGLAS}

\begin{tabular}{|c|c|}
\hline ANA & Agencia Nacional das Águas \\
\hline APA & Área de preservação ambiental \\
\hline ASCE & American Society of Civil Engineering \\
\hline BID & Banco Interamericano de Desenvolvimento \\
\hline BMP & Best Management Project - Melhores Práticas de Gerenciamento \\
\hline CAESB & Companhia de Água e Esgoto de Brasília \\
\hline CASQA & Califórnia Stormwater Quality Association \\
\hline CBH-AT & Comitê da Bacia Hidrográfica do Alto Tietê \\
\hline \multirow[t]{2}{*}{$\mathrm{CDHU}$} & Companhia de Desenvolvimento Habitacional e Urbano do \\
\hline & Estado de São Paulo \\
\hline $\mathrm{CDP}$ & Consistência de dimensionamento de projetos \\
\hline \multirow[t]{2}{*}{ CETESB } & Companhia de Tecnologia de Saneamento Ambiental do Estado \\
\hline & de São Paulo \\
\hline CNRH & Conselho Nacional de Recursos Hídricos \\
\hline CORHI & Comitê Coordenador do Plano Estadual de Recursos Hídricos \\
\hline $\mathrm{CRH}$ & Conselho Nacional de Recursos Hídricos \\
\hline DAEE & Departamento de Águas e Energia Elétrica \\
\hline DBO & Demanda Bioquímica de Oxigênio \\
\hline DER & Departamento de Estrada e Rodagem \\
\hline EPA & Environment Protection Agency \\
\hline FCTH & Fundação Centro Tecnológico de Hidráulica \\
\hline FIA & Fundação Instituto de Adminstração \\
\hline HUD & Housing and Urban Development Corporation \\
\hline HYDROAID & Water for Development Management Institute \\
\hline IBGE & Instituto Brasileiro de Geografia e Estatítica \\
\hline ICMS & Imposto sobre circulação de mercadorias e serviços \\
\hline IDF & Intensidade, Duração e Freqüência \\
\hline ITESP & Instituto de Terras do Estado de São Paulo \\
\hline
\end{tabular}


JICA

LID

MCIDADES

MMA

MUC

OMS

OSD

PERH

PNRH

PMSP

RMSP

SABESP

SCS

SEADE

SEMASA

$\mathrm{SH}$

SIG

SIGRH

SM

USP

ZEIS
Japan International Cooperation Agency

Low Impact Development - Desenvolvimento de Baixo Impacto Ministério das Cidades

Ministério do Meio Ambiente

Minessota Urban Concil

Organização Mundial da Saúde

On Site Detention

Plano Estadual de Recursos Hídricos

Plano Nacional de Recursos Hídricos

Prefeitura Municipal de São Paulo

Região metropolitana de São Paulo

Companhia de Saneamento Básico do Estado de São Paulo

Soil Conservation Service

Fundação Sistema Estadual de Análise de Dados

Serviço de Saneamento Ambiental de Santo André

Secretaria da Habitação

Sistema de Informações Geográficas

Sistema Integrado de Gerenciamento de Recursos Hídricos

Salários mínimos

Universidade de São Paulo

Zona especial de interesse social 


\section{APRESENTAÇÃO}

\subsection{Introdução}

Cheias são fenômenos naturais que ocorreram e ocorrem com certa regularidade e diferentes magnitudes, provocando o extravasamento de córregos e rios e justificando a existência de várzeas nas regiões de relevos mais amenos.

Desde a antigüidade, as cidades se desenvolveram próximas a essas fontes de água que representavam meios de sobrevivência (água e alimentação), transporte, comunicação e desenvolvimento, de modo que as cheias sempre se constituíram em motivos de fartura ou de preocupações.

Ações antrópicas, como a impermeabilização do solo através da crescente urbanização ou o aproveitamento das áreas de várzeas para outros fins diferentes da sua finalidade original de permitir o extravasamento dos córregos e rios, fizeram com que os eventos de cheias multiplicassem seu poder de atuação, causando prejuízos tangíveis e intangíveis dos mais diversos graus e tornando-se um dos maiores problemas contemporâneos, atingindo principalmente as cidades mais desenvolvidas, sem deixar de ser também motivo de apreensão por parte dos municípios de menor porte ${ }^{1}$.

O engenheiro Saturnino de Brito em 1925, já "lembrava que a inundação é um fenômeno da natureza e se o homem a considera uma calamidade é porque habita ou cultiva terras inundáveis que constituem elementos reguladores das águas correntes, cuja função é simples e conhecida: reter uma parte da água das chuvas ou das enchentes para fazer lentamente a entrega ao curso de água" (SANTOS, 2002) e afirmava que “ o problema das inundações é, portanto, um problema estabelecido pelos caprichos da atividade do homem" (BRITO, 1944 apud SANTOS, 2002).

\footnotetext{
${ }^{1}$ Segundo o IBGE (1998), a tendência de crescimento da população urbana tem sido recentemente caracterizada por uma pequena taxa de crescimento no núcleo das regiões metropolitanas e aumento do crescimento nas periferias e nas cidades que são pólos regionais de crescimento. A cidade de São Paulo entre 91 e 96, por exemplo, teve um aumento no núcleo de apenas $2 \%$ e na periferia de $16,3 \%$ (TUCCI e MARQUES, 2001). Cidades com mais de 1 milhão de habitantes têm crescido a uma taxa média anual de $0,9 \%$, enquanto núcleos regionais com população entre 100 e 500 mil, crescem 4,8\% (NETTO, 2003).
} 
Há certo tempo atrás, o único princípio a nortear a drenagem urbana era o conceito convencional do rápido afastamento/transporte da causa dos problemas, ou seja a vazão excedente, da sua origem. Esse princípio de rápido escoamento, apesar de eficiente por um lado, fez com que as inundações se agigantassem nas áreas de jusante, transferindo o problema de um ponto para outro, sem realmente combater sua origem que está focada na própria ação humana sobre a bacia hidrográfica (McCUEN, WALESH e RAWIS, 1983); (TUCCI, PORTO e BARROS, 1995) e (PARKINSON et al, 2003).

Entretanto, o crescimento dos custos e as limitações impostas pelas barreiras físicas e arquitetônicas existentes direcionam a adequação dos sistemas convencionais à inviabilidade técnica e econômica e, desta forma, os problemas permanecem sem solução ou com soluções pouco duradouras (TASSI, 2002) e (GRACIOSA, 2004).

Com o passar do tempo, instrumentados pelos resultados colhidos com as experiências anteriores e com uma visão mais holística e multidisciplinar da realidade, percebeu-se que era necessário modificar as formas de atuação e pensamento, abrandando os efeitos causados pela transferência dos problemas de cheias para jusante, até mesmo devido ao ponto de saturação alcançado, onde a convivência com esses eventos passou a ser mais freqüente e intensa, tornando-se insuportável tanto para a população como para seus dirigentes.

Surgiu então, um segundo princípio para a drenagem urbana, desta vez com uma abordagem mais moderna, mais ambiental do problema, considerando o conceito de armazenamento/retardamento para prevenir e mitigar os efeitos da urbanização e melhor distribuir as vazões ao longo do tempo, imitando e mantendo as características hidrológicas naturais da bacia hidrográfica .

Uma dessas alternativas, embora de conceitos simples e usados há muito tempo, com aplicações voltadas principalmente para irrigação e abastecimento de água, sem esquecer os aproveitamentos hidrelétricos, consiste na utilização de reservatórios com a finalidade específica de controle de cheias urbanas.

Esses reservatórios que procuram regularizar o escoamento superficial, armazenando o pico das cheias e restituindo-o gradualmente após o período crítico, em suas diversas formas, são dispositivos capazes de se adequarem às áreas 
consolidadas, densamente urbanizadas e com poucos espaços livres, que caracterizam a maioria das bacias hidrográficas dos grandes centros urbanos, principal alvo dos eventos de cheias.

Primeiramente conhecidos como "piscinões", popularizaram-se após o êxito na prevenção de inundações do reservatório de detenção implantado em frente ao Estádio do Pacaembú, na cidade de São Paulo, “o primeiro a ser inaugurado em 1995" (FIORAVANTI, 2004).

Inquestionáveis portanto, quanto à sua eficácia no combate às cheias urbanas desde que corretamente projetados, implantados e operados (WANIELISTA, 1990) e (PORTO, 1998), os reservatórios ou bacias de detenção se espalham pelas grandes cidades como uma das principais alternativas para atenuar as crescentes vazões das áreas urbanizadas ou em franco processo de urbanização (TUCCI e MARQUES, 2001).

Embalados pelo sucesso dos reservatórios de detenção públicos de grande porte, pela crescente conscientização da população e das autoridades quanto à necessidade de conservação das características naturais das bacias hidrográficas, pela elaboração dos planos diretores e pelas restrições existentes à implantação dos "piscinões", crescem também os municípios que criam exigências quanto à implantação de pequenos reservatórios de detenção, as "piscininhas" ou microreservatórios, em lotes ou loteamentos urbanos particulares.

Esses dispositivos embasados no princípio da manutenção das vazões existentes antes da urbanização, buscam contornar a falta de espaços públicos disponíveis e distribuir o ônus de novas intervenções com aqueles que as demandam (LOUCKS, 1998); (WANIELISTA, 1990) e (URBONAS, 1999).

Porém, por tratar-se de um elemento novo que despende espaço, gastos e novas responsabilidades, traz consigo um cenário de desconforto, incertezas e resistência por parte de técnicos e proprietários (TUCCI e MARQUES, 2001).

Ao mesmo tempo, eles aproximam o público do privado na medida em que solicitam a utilização do "quintal" de cada habitante para solucionar problemas de desenvolvimento urbano e pressupõem não somente mudanças nos critérios de projeto e na forma de atuação profissional, mas também uma mudança fundamental 
de comportamento da sociedade, através da melhor compreensão dos fenômenos correlatos e do efetivo exercício da cidadania.

A CDHU - Companhia de Desenvolvimento Habitacional e Urbano do Estado de São Paulo - como promotora de construção de habitação popular no estado de São Paulo, embora de maneira ainda incipiente e principalmente em respeito às legislações municipais, tem projetado e implantado reservatórios de detenção em alguns dos seus empreendimentos, enfrentando diferentes questões de todas as ordens.

Considerando a população a qual se destina seus conjuntos habitacionais, a implantação de reservatórios de detenção levanta questões difíceis de serem equacionadas, em face às prioridades dos moradores, sua situação econômica e sua capacidade de absorção da importância ambiental dessas soluções, pautada principalmente no fato de que grande parte dos benefícios alcançados são indiretos.

Assim, perante a crescente demanda pela implantação de reservatórios de detenção e as peculiaridades do público alvo, observou-se a necessidade de melhor estudar o tratamento dispensado a este novo tipo de dispositivo de infraestrutura urbana e as decorrências práticas de sua viabilização.

Este trabalho então, na medida em que apresenta as preocupações, enumera os problemas e analisa os acontecimentos desencadeados pela necessidade de implantação de reservatórios de detenção nos conjuntos habitacionais da CDHU, cria subsídios aos interessados em geral nesse assunto para reflexões acerca desta "nova" ferramenta de drenagem urbana, através do estudo de casos reais, e propõe um roteiro com diretrizes gerais para melhor incorporar estes dispositivos nos processos produtivos e atender as peculiaridades locais e sociais de cada empreendimento. 


\subsection{Objetivo}

Em função da relevância dos reservatórios de detenção em lotes e loteamentos urbanos como dispositivos de planejamento e controle da drenagem urbana, da importância adquirida pelos mesmos nos últimos anos e alavancada pela necessidade de implantação também em conjuntos habitacionais para população de baixa renda, propõe-se:

- levantar o panorama técnico, econômico e social que envolveram alguns dos conjuntos habitacionais da CDHU onde este tipo de estrutura se fez necessário e seus desdobramentos, desde a averiguação da demanda, passando por concepção, projeto, construção, operação e manutenção, sempre que houverem dados disponíveis;

- apresentar o panorama existente, as soluções e dificuldades encontradas, os questionamentos, as dúvidas e os dilemas criados na implantação e utilização destes dispositivos;

- analisar as questões levantadas, sugerir alternativas e recomendações para o aprimoramento do trabalho dos agentes envolvidos no processo;

- elaborar um roteiro com diretrizes gerais para facilitar a incorporação destes dispositivos em novos empreendimentos, respeitando as características e particularidades locais.

Desta forma, baseado nas experiências da CDHU com a implantação de reservatórios de detenção, espera-se consolidar dados e informações que venham a colaborar e subsidiar trabalhos futuros para que estes sejam cada vez mais acurados e possam realmente interceder de forma crescentemente positiva no desenvolvimento e harmonia da relação entre a população e as cidades. 


\subsection{Desenvolvimento e Metodologia}

A elaboração e estruturação desta dissertação observará os seguintes tópicos:

- Conceituação resumida das inundações urbanas, das medidas de controle de cheias, de aspectos da qualidade da água das chuvas e da legislação em vigor;

- Conceituação das estruturas alternativas ou compensatórias, apresentação das tipologias principais e do panorama internacional;

- Caracterização e detalhamento dos reservatórios de detenção, apresentação de estudos e experiências, além de considerações sobre legislações específicas;

- Apresentação da CDHU, da população beneficiária e da filosofia utilizada na concepção dos sistemas de drenagem;

- Seleção dos conjuntos habitacionais da CDHU com reservatórios de detenção, levantamento e organização dos dados e informações disponíveis e averiguação do estado atual dos reservatórios em operação;

- Apresentação, avaliação e síntese dos resultados obtidos, incluindo descrição de itens considerados primordiais e críticos para evolução dos dificuldades e impasses encontrados nos processos de implantação dos reservatórios;

- Proposição de roteiro com diretrizes gerais para facilitar a incorporação dos reservatórios de detenção nos processos produtivos;

- Conclusões e recomendações. 


\section{INUNDAÇÕES URBANAS}

O termo drenagem urbana, segundo TUCCI (1997) e PORTO e FILHO (2004), pode ser entendido como o conjunto de obras e medidas relativas ao escoamento gerado pelas águas pluviais que tenham por objetivo minimizar os riscos a que as populações estão sujeitas, diminuir os prejuízos causados por inundações e possibilitar o desenvolvimento urbano de forma harmônica, articulada e sustentável.

Em relação aos outros melhoramentos urbanos (água, energia, pavimentação, etc.), o sistema de drenagem apresenta uma particularidade que é a ocorrência das águas pluviais, independentemente da existência ou não de sistemas adequados, sendo a quantidade e qualidade dos mesmos, fatores determinantes dos benefícios e prejuízos causados à população (CETESB, 1986). Outra característica distinta é sua solicitação não permanente, contrastando com o uso contínuo dos demais elementos da infraestrutura urbana (PMSP/FCTH, 1999).

O desenvolvimento da bacia hidrográfica muda as características de uso e ocupação do solo, propiciando a remoção da camada vegetal, a terraplenagem das áreas e a impermeabilização das superfícies.

A remoção da camada vegetal influi na capacidade de interceptação da água pelo solo e na sua resposta aos processos erosivos. A terraplenagem, além de favorecer a produção de sedimentos, reduz a infiltração devido à compactação do solo e o armazenamento pela eliminação das depressões naturais existentes. Analogamente, o armazenamento nas depressões em superfícies impermeáveis são menores do que nas superfícies permeáveis, assim como a utilização de pisos impermeáveis elimina a infiltração e reduz a rugosidade das superfícies (McCUEN, WALESH e RAWIS, 1983) e (TUCCI, 1995).

Todas as alterações citadas modificam os processos naturais da bacia hidrográfica, inclusive a recarga dos aqüíferos, e aumentam as vazões e os volumes de escoamento superficial, sendo assim, responsáveis pelo aumento dos problemas de inundações e por modificações no ciclo hidrológico ${ }^{2}$.

\footnotetext{
${ }^{2}$ Trabalho apresentado por TUCCI e MARQUES (2001), que analisa o impacto quantitativo de ações antrópicas sobre uma bacia hidrográfica, indica que um habitante introduz cerca de $49 \mathrm{~m}^{2}$ de área impermeável e que para cada $10 \%$ de aumento de área impermeável, ocorre cerca de $100 \%$ de
} 
Durante muito tempo, por mais de 100 anos nos países desenvolvidos, o objetivo principal da drenagem urbana foi remover as águas pluviais em excesso da forma mais eficiente possível (TUCCI, 1997) e (SCOTT, SANTOS e ARGUE, 1999).

Esta forma de pensamento condicionou o sistema de drenagem urbana existente em todas as cidades brasileiras, e foi caracterizada pela implantação de galerias de águas pluviais e seus acessórios e por retificação e canalização de corpos d'água, que reduziram drasticamente o tempo de percurso do escoamento superficial e o tempo de pico dos hidrogramas, trazendo graves conseqüências principalmente para áreas à jusante (TUCCI, PORTO e BARROS, 1995).

A procura por soluções que amenizassem esses prejuízos através do aumento da eficiência hidráulica, levou a outras modificações nos cursos naturais das águas, a implantação de novos canais e galerias e agravaram ainda mais a situação existente (TASSI, 2002), criando a necessidade de novas intervenções e repetindo os padrões anteriores.

A inviabilidade dessas ações de adequação dos sistemas de drenagem foi admitida por LEOPOLD (1968) apud TUCCI (2001), uma vez que o impacto da urbanização sobre a vazão média de cheias pode chegar a ser até sete vezes maior do que a vazão natural das enchentes.

TUCCI (2003) observou que o aumento relativo da vazão máxima devido à impermeabilização do solo e à ocupação da bacia hidrográfica, pode ser superior a seis vezes a situação pré-desenvolvimento ${ }^{3}$, confirmando tanto os valores encontrados por LEOPOLD, quanto a gravidade do impacto causado pela urbanização.

Outra característica, a inerente particularidade de ocupação das bacias que habitualmente ocorre de jusante para montante como forma de aproveitamento das característica do relevo, também concorre para a intensificação deste problema (TUCCI, PORTO e BARROS, 1995) e (TUCCI,1997).

SPIRN (1995) recorda que soluções para as questões relacionadas com a água na cidade são freqüentemente encontradas a montante de onde os problemas são

\footnotetext{
aumento no volume de escoamento superficial comparado com a condição rural.

${ }^{3}$ Embasado no estudo da bacia do Rio Belém $\left(42 \mathrm{~km}^{2}\right)$, responsável pela drenagem da área central da cidade de Curitiba.
} 
sentidos com maior impacto e que "a prática tradicional da drenagem protege ruas locais, subterrâneos e estacionamentos contra as enchentes, enquanto contribuem para um dano maior de inundação mais abaixo".

Canholi (2000) ressalta ainda que o problema das inundações foi particularmente agravado nos países emergentes, pela velocidade do processo de adensamento populacional e pela precariedade da infra-estrutura, aliada à falta de planejamento e à carência de recursos.

Entretanto, a gravidade e a freqüência com que as inundações atingem cidades e regiões metropolitanas como São Paulo (figura 1), Campinas, Rio de Janeiro, Belo Horizonte e Recife, demonstram a necessidade de procurar novas alternativas, através da compreensão mais integrada do ambiente urbano e das relações entre os sistemas que o compõem, além de conhecer melhor a fenomenologia climatológica, hidráulica, hidrológica e ambiental do problema, associada à análise de questões relativas à saúde e saneamento, bem como dos demais aspectos, inclusive político-institucionais (CANHOLI, 1995) e (TUCCI, 1997).

Segundo SPIRN (1995), “a chave para alcançar soluções eficientes, efetivas e econômicas é a compreensão das várias maneiras como as águas se movem através da cidade", e então procurar melhorar o convívio do homem com as imposições da natureza e com as conseqüências de suas ações. 

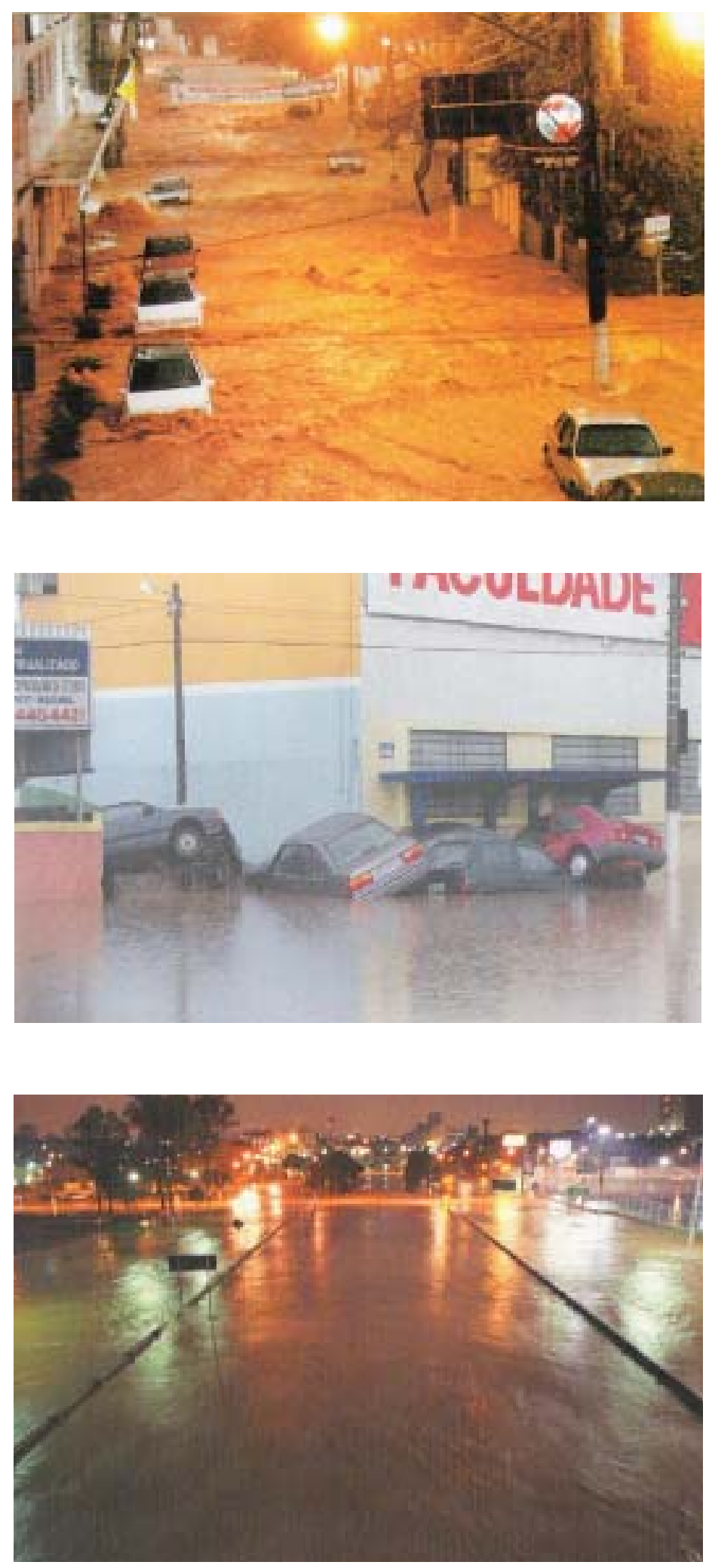

Figura 1 - Enchentes na região metropolitana de São Paulo Fonte : DG ABC apud Santos (2002) 


\subsection{Classificação das Inundações e a Influência da Urbanização}

As inundações são decorrentes de processos de urbanização e de ocupação natural das várzeas ribeirinhas pelos córregos e riachos, podendo ocorrer isoladamente ou de forma integrada. Essas inundações podem ser classificadas como (TUCCI, PORTO e BARROS, 1995):

- inundações em áreas ribeirinhas: provocada por processo natural em decorrência de chuvas de maior magnitude, onde o rio ocupa seu leito maior, e é ocasionada principalmente pela ocupação inadequada do espaço urbano, como por exemplo, as marginais do Rio Tietê em São Paulo (figura 2). Esse evento costuma acontecer pelo menos uma vez a cada dois anos em bacias grandes com mais de $500 \mathrm{~km}^{2}$ (NETTO, 2003) e (TUCCI e MARQUES, 2001). LUNA e LEOPOLD (1974) apud SPIRN (1995) informam que a forma e o tamanho do leito natural de um rio refletem o tamanho e a freqüência das inundações aos quais ele está sujeito. A figura 3 ilustra a ocupação das várzeas pelas cheias e a recorrência previsível com que isso acontece;

- inundações devido à urbanização: decorrente da impermeabilização do solo e da implantação de redes de condutos que passam a não permitir processos de infiltração e/ou interceptação, aumentando o volume do escoamento superficial e a vazão máxima, antecipando o tempo de pico dos hidrogramas de cheias e interferindo na frequiência e magnitude das enchentes (figura 4, 5, 6, 7 e 8). A produção de ilhas de calor na parte central dos centros urbanos onde predomina $\mathrm{o}$ concreto e o asfalto, também contribuem para o aumento de precipitações mais intensas com baixa duração, agravando as enchentes urbanas (TUCCI e MARQUES, 2001). Sua relação com a urbanização pode ser visualizadas na figura 9;

- inundações localizadas: ocasionada por estrangulamento de seções, por remanso, por obstruções, por assoreamento ou por erros de execução ou dimensionamento, criam condições inadequadas de drenagem urbana. 


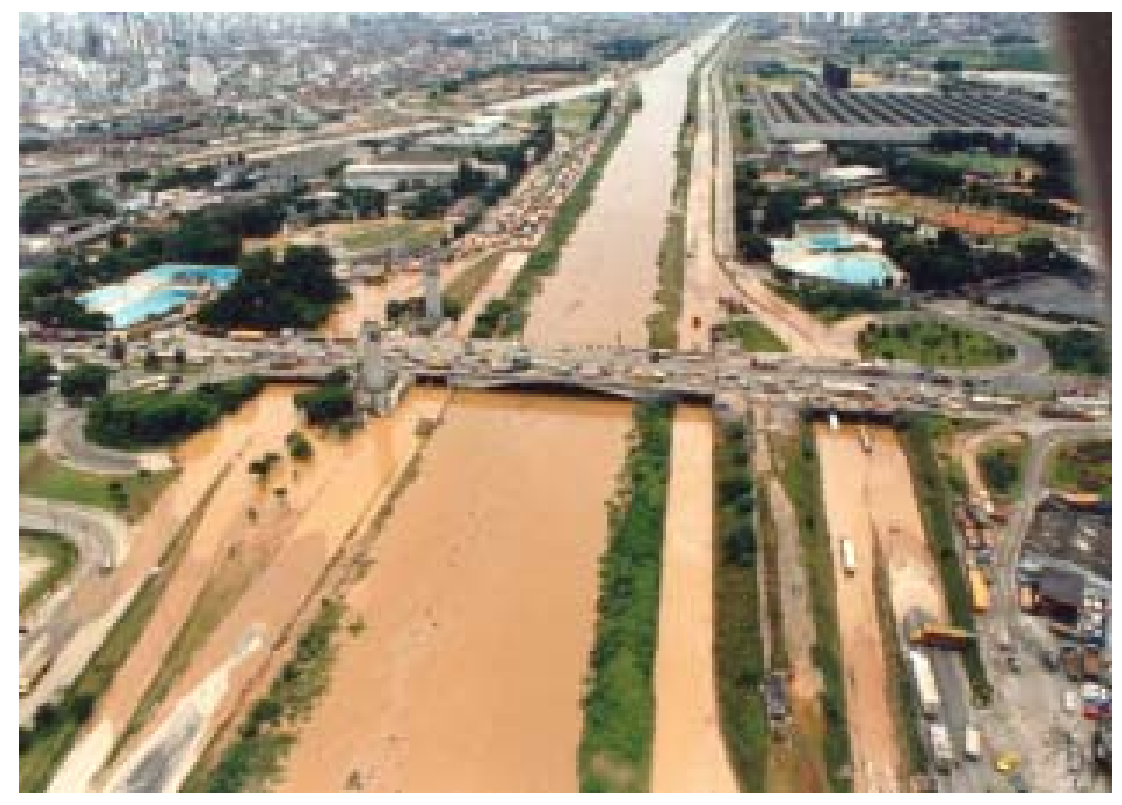

Figura 2 - Inundação da Calha do Tietê na década de 90

Fonte : DAEE apud Santos (2002)
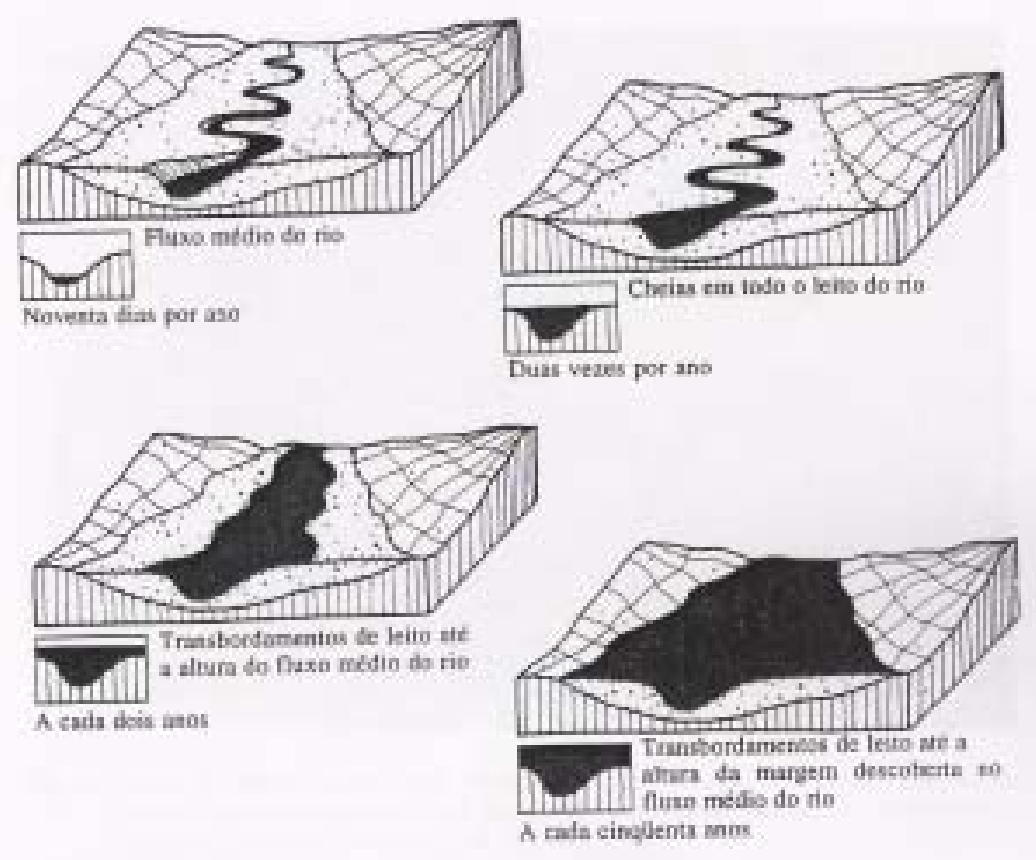

Figura 3 - Ocupação das várzeas pelas cheias e sua recorrência Fonte : Luna e Leopold apud Spirn (1995) 


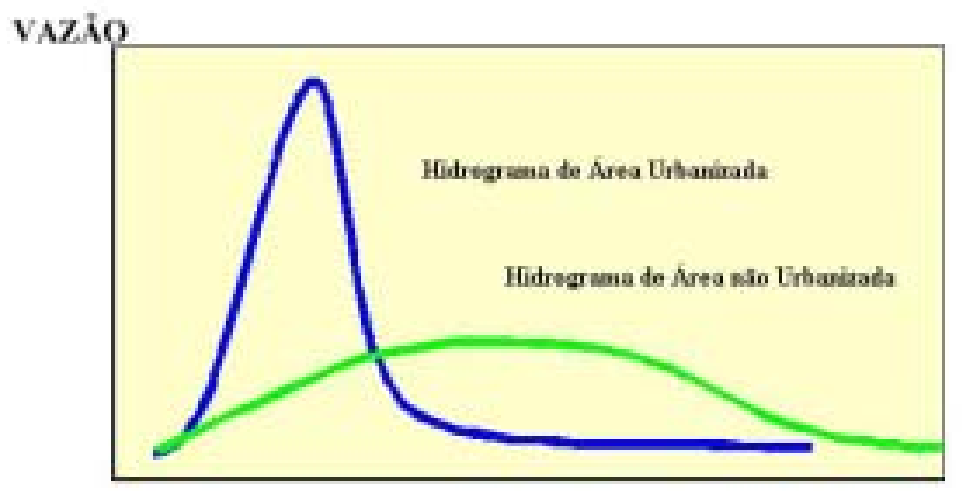

TEMPO

Figura 4 - Efeito da urbanização sobre o hidrograma pré-existente

Fonte : Mota e Tucci (1984) apud Tucci, Porto e Barros (1995)

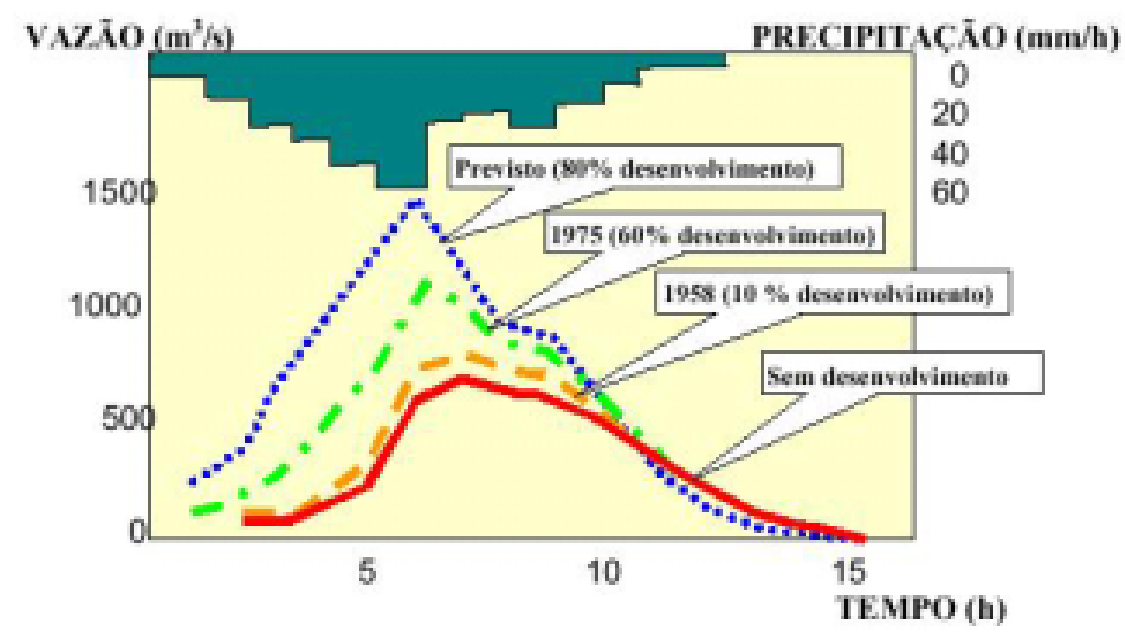

Figura 5 - Efeito da evolução da urbanização sobre o hidrograma pré-existente Fonte : Yoshimoto e Suetsugi (1990) apud Tucci, Porto e Barros (1995) 


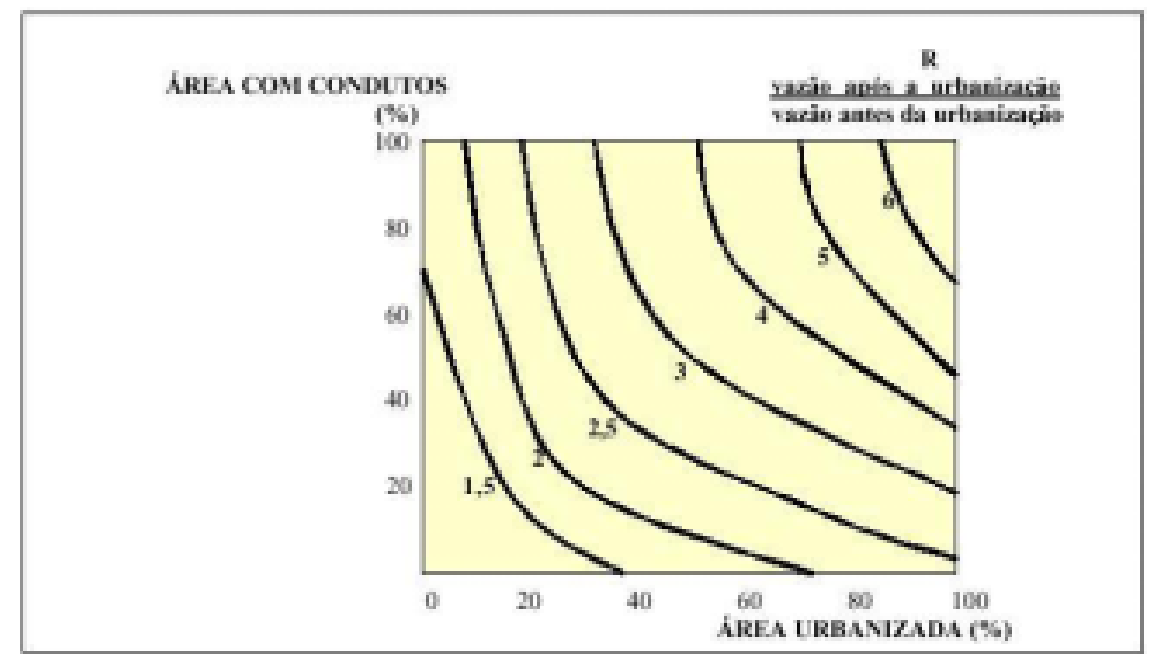

Figura 6 - Efeito da urbanização sobre a vazão máxima de rios urbanos Fonte : Leopold (1968) apud Tucci, Porto e Barros (1995)

- TEMPO dE CONCENTRAÇÃo (h)

- ÁREA URBanizada (\%)

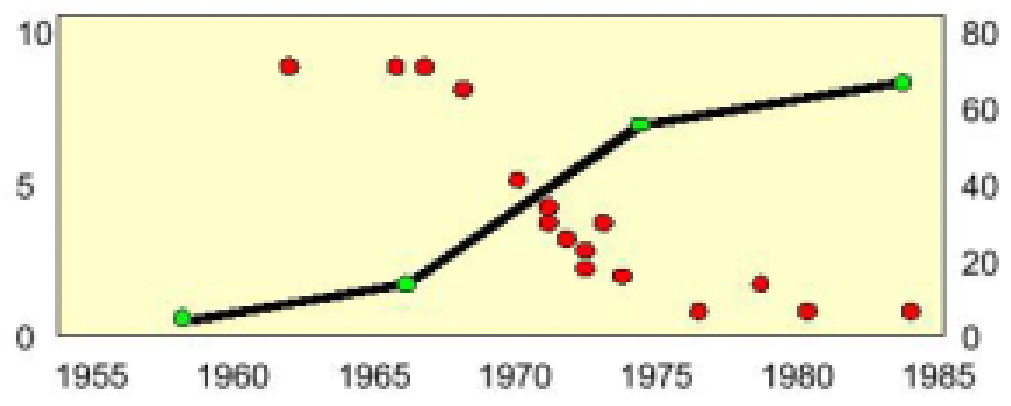

Figura 7 - Efeito da urbanização sobre o tempo de concentração Fonte : Yoshimoto e Suetsugi (1990) apud Tucci, Porto e Barros (1995) 


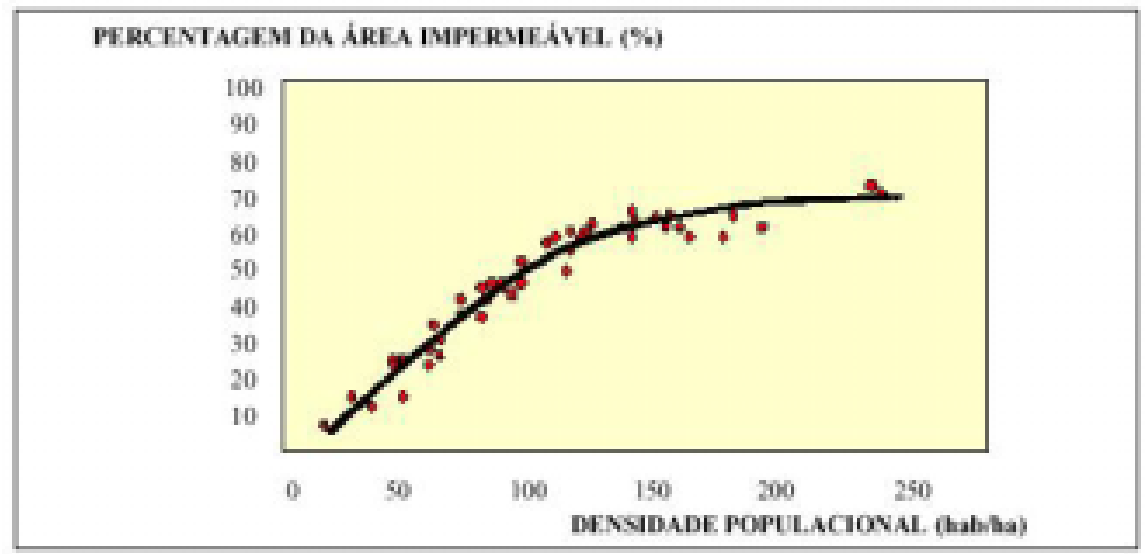

Figura 8 - Efeito da densidade populacional sobre a área impermeável Fonte : Campana e Tucci (1994)

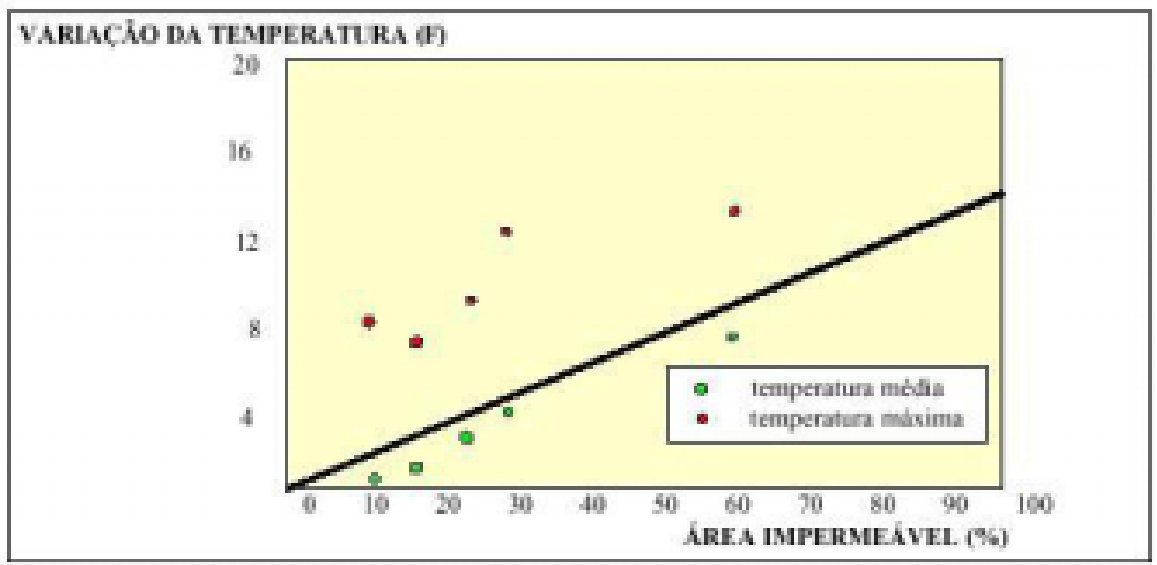

Figura 9 - Efeito da área impermeável sobre a variação da temperatura Fonte : Galli (1990) apud Tucci e Marques (2001)

As inter-relações entre os diversos processos que envolvem o desenvolvimento de uma área urbana são ilustradas por HALL (1984) apud TUCCI (1997) na figura 10, e suas relações causa-efeito demonstradas pela tabela 1. 


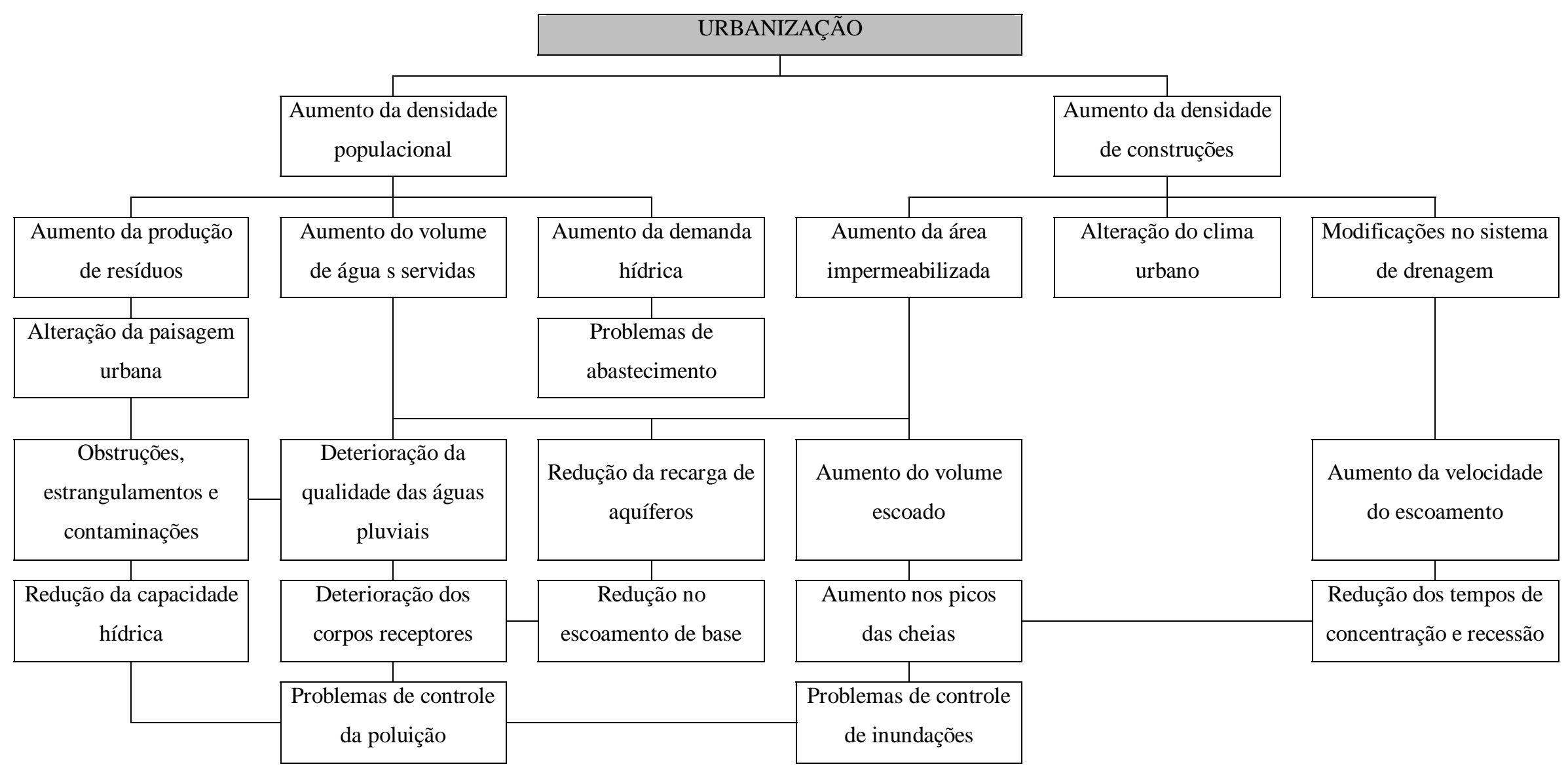

Figura 10 - Processos que envolvem o desenvolvimento de uma área urbana

Fonte : Hall (1984) apud Tucci (1997) - modificado 
Ainda segundo TUCCI (1997), o equacionamento eficiente e sustentável dos principais problemas apontados é obtido atuando-se sobre as causas e considerando todas as inter-relações existentes, nos intricados sistemas que são as cidades.

"Não menos importante são as ações de monitoramento para acompanhamento da evolução dos complexos processos que ocorrem na bacia, já que a base de dados é ferramenta fundamental para a correta tomada de decisão" (TUCCI e MARQUES, 2001).

Tabela 1 - Causas e efeitos da urbanização sobre as inundações

\begin{tabular}{|c|c|}
\hline Causas & Efeitos \\
\hline impermeabilização & $\begin{array}{l}\text { - maiores picos e vazões; } \\
\text { - redução do tempo de concentração } \\
\text { - redução das interceptações e da evapotranspiração; } \\
\text { - redução do coeficiente de rugosidade. }\end{array}$ \\
\hline $\begin{array}{l}\text { sistema de drenagem } \\
\text { convencional }\end{array}$ & $\begin{array}{l}\text { - maiores picos a jusante; } \\
\text { - redução do tempo de concentração. }\end{array}$ \\
\hline resíduos sólidos & $\begin{array}{l}\text { - degradação da qualidade da água; } \\
\text { - obstrução, estrangulamento e assoreamento; } \\
\text { - redução da capacidade hidráulica dos sistemas; } \\
\text { - alteração da paisagem urbana. }\end{array}$ \\
\hline redes de esgotos insuficientes & $\begin{array}{l}\text { - degradação da qualidade da água; } \\
\text { - moléstias de veiculação hídrica; } \\
\text { - consequiências mais sérias em inundações }\end{array}$ \\
\hline $\begin{array}{l}\text { desmatamento e ocupação } \\
\text { irregular de encostas }\end{array}$ & $\begin{array}{l}\text { - maiores picos e volumes; } \\
\text { - redução do tempo de concentração; } \\
\text { - produção de sedimentos por processos erosivos; } \\
\text { - assoreamento de canais e galerias }\end{array}$ \\
\hline ocupação irregular das várzeas & $\begin{array}{l}\text { - maiores prejuízos; } \\
\text { - maiores picos e velocidades; } \\
\text { - maiores custos de utilidade públicas }\end{array}$ \\
\hline
\end{tabular}

(Fonte: Tucci,1997 - modificado) 


\subsection{Cenário Atual}

No início de 2004, 338 municípios de 15 estados viram-se em situação de emergência, 84 pessoas morreram e 104 mil perderam suas casas por causa das chuvas fortes (FIORAVANTI, 2004).

Atualmente durante a estação chuvosa existem mais de cinco grandes eventos que causam transtornos e prejuízos às cidades (TUCCI e MARQUES, 2000).

Pesquisa feita pelo IBGE, demonstra que aproximadamente $1 / 4$ dos municípios brasileiros foram vítimas de inundações entre 1998 e 1999 (tabela 2), e aponta os principais fatores de agravamento (tabela 3), onde observa-se que as duas primeiras posições (obstruções de bueiros e bocas de lobo e adensamento populacional) são ocupadas por itens decorrentes ou agravados pela urbanização.

Tabela 2 - Municípios atingidos pelas inundações entre 1998 e 1999

\begin{tabular}{|l|c|c|c|c|c|c|}
\hline Região & Brasil & Norte & Nordeste & Sudeste & Sul & $\begin{array}{c}\text { Centro- } \\
\text { Oeste }\end{array}$ \\
\hline Total de municípios & 5507 & 449 & 1787 & 1666 & 1159 & 446 \\
\hline Sofreram inundações & 1235 & 57 & 238 & 539 & 356 & 45 \\
\hline porcentagem & 22,4 & 12,7 & 13,3 & 32,4 & 30,7 & 10,1 \\
\hline
\end{tabular}

(Fonte: IBGE, 2002)

GRACIOSA (2004) observa que recentemente, os órgãos tomadores de decisão em recursos hídricos têm-se empenhado na busca de soluções que focalizem as razões fundamentais dos problemas de drenagem urbana e que venham de encontro ao conceito de desenvolvimento sustentável ${ }^{4}$.

\footnotetext{
${ }^{4}$ Conceituado pela ONU como um modelo que visa suprir as necessidades atuais da humanidade sem colocar em risco a capacidade das gerações futuras também o fazerem, ou seja, um mecanismo que permite o crescimento econômico dos países com maior justiça social e em harmonia com a natureza.
} 
Tabela 3- Fatores agravantes das inundações

\begin{tabular}{|l|c|c|c|c|c|c|}
\hline Região & Brasil & Norte & Nordeste & Sudeste & Sul & $\begin{array}{c}\text { Centro- } \\
\text { Oeste }\end{array}$ \\
\hline $\begin{array}{l}\text { Dimensionamento } \\
\text { inadequado de projeto }\end{array}$ & 339 & 8 & 63 & 166 & 92 & 10 \\
\hline $\begin{array}{l}\text { Obstrução de bueiros e } \\
\text { bocas de lobo }\end{array}$ & 631 & 38 & 123 & 260 & 192 & 18 \\
\hline Obras inadequadas & 345 & 16 & 67 & 145 & 104 & 13 \\
\hline Adensamento populacional & 391 & 16 & 75 & 192 & 95 & 13 \\
\hline Lençol freático alto & 205 & 13 & 54 & 69 & 58 & 11 \\
\hline $\begin{array}{l}\text { Existência de interferência } \\
\text { física }\end{array}$ & 298 & 8 & 57 & 130 & 91 & 12 \\
\hline Outros & 237 & 13 & 26 & 110 & 78 & 10 \\
\hline Sem declaração & 3 & 1 & 1 & 1 & - & - \\
\hline Área inundada (ha) & 48.809 & 1.629 & 6.606 & 10.171 & 28.176 & 2.227 \\
\hline
\end{tabular}

(Fonte: IBGE, 2002)

Esses conceitos mais modernos de drenagem urbana buscam além da eficiência hidráulica dos sistemas, gestão eficiente, melhoria da qualidade da água, integração ao meio ambiente e respaldo público, tendo como princípios básicos (CANHOLI, 1995); (LOUCKS, 1998); (TUCCI e MARQUES, 2000 e 2001) e (BINDER, 1998):

- manter as condições de pré-urbanização da bacia;

- promover o retardamento dos escoamentos, aumentando os tempos de concentração e reduzindo as vazões máximas;

- amortecer os picos de enchentes e redistribuir as vazões ao longo do tempo, através de estruturas de armazenamento;

- conter os escoamentos na origem ou nas suas proximidades;

- melhorar e promover as condições de infiltração através de dispositivos auxiliares; 
- aperfeiçoar a concepção dos projetos através da imitação do ciclo hidrológico/hidráulico natural, prevendo a manutenção das taxas de infiltração e interceptação, dos tempos de escoamento, das vazões e dos volumes;

- "renaturalizar" os sistemas de drenagem existentes, procurando recriar condições naturais, como por exemplo com a criação de meandros ilustrados na figura 11 .
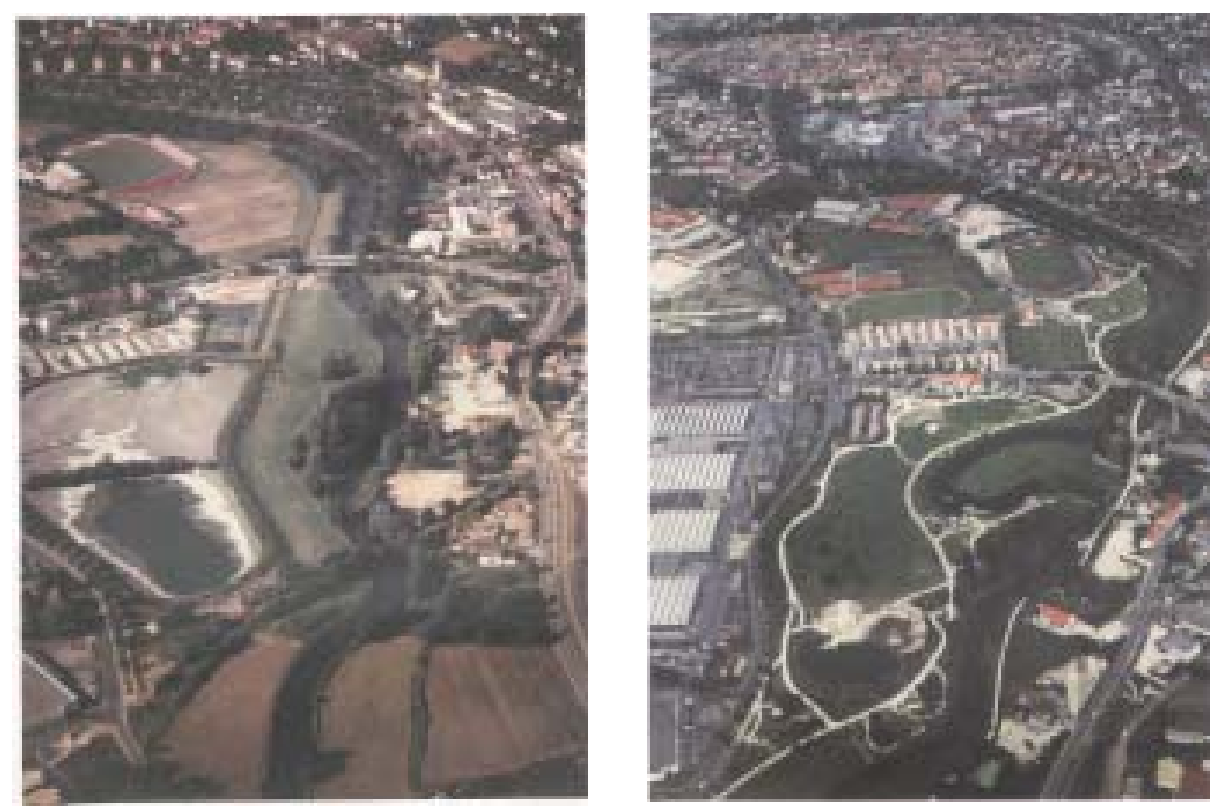

Figura 11 - Rio Vils em Amberg em 1990 e após renaturalização Fonte : Binder (1998)

Segundo BARROS (2003), estes princípios, em muitas situações, correspondem a atuações opostas às que num passado próximo, eram ainda apontadas como desejáveis sob o ponto de vista de melhoramento das condições hidráulicas de escoamento.

BINDER (1998) em seu estudo sobre alternativas de recomposição de rios impactados cujas condições naturais foram alteradas por obras realizadas em seu leito, observa que os custos para manter a evolução natural do rio são pequenos se comparados com os custos de obras hidráulicas tradicionais e sua manutenção, e com os custos de obras de engenharia ambiental para renaturalização dos rios. Para o 
autor a renaturalização de rios não significa a volta a uma paisagem original não influenciada pelo homem, mas ao desenvolvimento sustentável dos rios e da paisagem em conformidade com as necessidades e conhecimentos contemporâneos.

FIORAVANTI (2004) considera que com a participação popular, ou por meio de novas leis, procura-se agora reduzir a impermeabilização, que é um dos agravantes das enchentes, e em paralelo ao esforço de oferecer espaços para a água se infiltrar, a freqüência dos alagamentos levou a uma revisão conceitual e já não se pensa mais que somente a construção de grandes reservatórios de detenção temporária de água, os piscinões, e a canalização de rios, vão acabar com o suplício dos finais e começos de ano.

Entretanto, para SILVEIRA (2000) citado por TASSI (2002), a grande maioria das obras de drenagem no Brasil, com raras exceções, segue até os dias atuais, o conceito higienista do século XIX de eliminação sistemática das águas e aponta como razão para manutenção desta postura o fato do conceito "ambiental" ser mais difícil e, em geral, mais caro de aplicar por exigir ações integradas sobre grandes áreas com utilização de conhecimentos técnicos multidisciplinares, contrapondo as ações higienistas enfocadas em soluções locais e concebidas unicamente por engenheiros.

Para TUCCI citado por FIORAVANTI (2004) e TUCCI e MARQUES (2001), "não há incentivos à prevenção contra enchentes no Brasil, porque há um ganho político quando os municípios entram em estado de calamidade pública por causa das enchentes, e os prefeitos recebem dinheiro a fundo perdido que podem usar sem licitação".

TUCCI, PORTO e BARROS (1995) consideram que o poder público deve zelar pelo controle da urbanização e monitorar a capacidade dos sistemas de drenagem, de forma a evitar o aumento da ocorrência de enchentes com perdas sociais e econômicas .

São considerados fatores preponderantes (boas técnicas) para definição de soluções eficazes em drenagem urbana e controle de cheias (TUCCI, 1997) e (NETO, 2004), desde que acompanhadas de um bom planejamento, porém ainda distantes da realidade brasileira: 
- criação de política para o setor com a definição de objetivos e os meios para alcançá-los (legais, técnicos, institucionais e financeiros);

- definição do uso e ocupação do solo urbano, de forma articulada com a política de drenagem urbana, principalmente com relação à ocupação das áreas passíveis de inundações e a conservação das condições existentes;

- planejamento integrado da bacia com medidas de curto, médio e longo prazos, devidamente integrado com o complexo maior do meio ambiente urbano;

- domínio da tecnologia e alternativas existentes tanto para planejamento, projeto e construção, quanto para operação e manutenção;

- existência de entidade que exerça a liderança no setor, articulando o uso das tecnologias necessárias, a efetivação das medidas planejadas, o envolvimento e participação públicas, a obediência às legislações vigentes, etc.;

- desenvolvimento de campanhas para educação ambiental e para esclarecimento da opinião pública.

E segundo TUCCI (1997), no Brasil não há programas sistemáticos de gerenciamento e controle da ocupação de áreas de risco de inundações pelas seguintes razões:

- falta de conhecimento por parte dos planejadores urbanos sobre os métodos de prevenção de enchentes;

- desorganização dos órgãos federais, estaduais e municipais para gerenciamento efetivo do problema;

- informação técnica incipiente sobre o tema nos cursos de graduação na engenharia;

- desgaste político devido à frustração da população perante medidas preventivas que não geram obras de engenharia;

- falta de educação da população sobre controle de enchentes. 


\subsection{Medidas de Controle de Cheias Urbanas}

O termo controle de cheias advém da necessidade de identificação das técnicas utilizadas na tentativa de mitigar o potencial de estragos proporcionados pelas chuvas em decorrência do desenvolvimento urbano e de quebrar a sequiência de novas intervenções.

CUNDOM E GUTIÉRREZ (2001) observam que a adoção de medidas de controle dependem do reconhecimento do estado atual da bacia hidrográfica e da identificação das oportunidades de implantação, sendo função direta do momento de intervenção local.

Desta forma, o desempenho das medidas de controle "estará sempre associado à quantidade e à qualidade dos informações e dados básicos disponíveis e ao conhecimento e experiência dos técnicos encarregados da elaboração do projeto" (PMSP/FCTH, 1999).

Esse controle é realizado não somente através da utilização dos conhecimentos adquiridos ao longo do tempo sobre os fenômenos físicos envolvidos e o aproveitamento destes na criação e aprimoramento de tecnologias alternativas, como também pela observação do comportamento humano e sua maneira e capacidade de interferir nos processos ambientais.

Para minimizar os efeitos negativos do desenvolvimento de uma bacia hidrográfica e evitar o redimensionamento dos sistemas de drenagem, os efeitos da urbanização sobre o ciclo hidrológico devem ser conhecidos e reparados. Assim, as medidas de controle de inundações devem ser delineadas para minimizar os efeitos hidrológicos adversos, repor o armazenamento natural perdido e neutralizar as mudanças nos tempos dos processos naturais da bacia (McCUEN, WALESH e RAWIS, 1983).

Os principais benefícios das medidas de controle da drenagem urbana são (PORTO e FILHO, 2004 - modificado):

- redução de perdas humanas e de doenças de veiculação hídrica;

- redução de prejuízos, de paralisações e de transtornos decorrentes;

- redução dos custos para recomposição das áreas atingidas;

- maiores oportunidades de recreação; 
- aumento das áreas verdes e espaços urbanos;

- melhoramento da proteção das margens;

- menor assoreamento.

Entretanto, há que se considerar que "as inundações catastróficas são risco permanente, não eliminadas por quaisquer obras. Os próprios processos de avaliação das vazões de projetos são geralmente empíricos e quando empregados fora das condições para as quais foram elaborados, torna-se difícil a exata determinação dos parâmetros intervenientes" (EMPLASA, 1985) e "é ingenuidade do homem imaginar que poderá controlar totalmente as inundações". Segundo BERNARDES apud FIORAVANTI (2004), “em algum momento, qualquer barreira será superada porque as chuvas sempre podem ser mais intensas do que as consideradas nos projetos de engenharia".

Conscientes destes fatos, as medidas de controle das cheias urbanas sempre visam a minimização das suas conseqüências e a convivência harmônica com seus infortúnios (TUCCI, 1997). A escolha conveniente entre as alternativas possíveis faz-se pela adoção de "uma política ou partido de atuação que determine as decisões presentes e futuras" (CANHOLI, 1995), de acordo com a especificidade de cada bacia hidrográfica.

É improvável que medidas de controle sejam capazes de eliminar todos os efeitos adversos sobre os sistemas existentes, causados pelo crescimento populacional, especialmente nos grandes centros urbanos, porque esse crescimento tem sido caracterizado pela expansão irregular da periferia, sem observância das normas e legislações em vigor, além da ocupação irregular das áreas públicas pela população de baixa renda (URBONAS, 1999) e (TUCCI e MARQUES, 2001).

Nenhuma medida de controle do escoamento superficial e prevenção de enchentes, isolada ou conjuntamente, propicia uma proteção completa e pode ainda criar uma falsa sensação de segurança que permitirá a ampliação da ocupação das áreas inundáveis, causando futuramente, danos maiores e mais significativos (TUCCI, 1997).

Convém lembrar que a drenagem urbana não está restrita a aspectos puramente técnicos impostos pelos limites da engenharia e compreende a totalidade 
de medidas passíveis de serem implantadas para prevenção e atenuação de riscos e prejuízos decorrentes das inundações (NETO, 2004).

\subsubsection{Classificação das medidas de controle}

As medidas de controle de cheias podem ser classificadas de maneiras diversas: quanto ao modo de intervenção, quanto à conceituação envolvida e quanto ao local de intervenção.

\subsubsection{Modo de intervenção}

Considerando o modo de intervenção, as medidas de controle são classificadas como (EMPLASA, 1985); (TUCCI, PORTO e BARROS, 1995) e (CANHOLI, 1995):

- medidas estruturais: são todas e quaisquer obras de engenharia (afastamento, armazenamento, prevenção, controle, etc.) relacionadas com o gerenciamento das águas pluviais, podendo ser extensivas quando interferem em toda a bacia modificando as relações entre precipitação e vazão (melhoria da cobertura vegetal, por exemplo) ou intensivas quando agem diretamente no curso d'água, acelerando o escoamento (galerias e canais), aumentando a capacidade de descarga (diques e polders), retardando o escoamento (reservatórios de amortecimento e infiltração) ou desviando o escoamento (canais de derivação);

- medidas não-estruturais: são aquelas de natureza institucional, administrativa ou financeira, de caráter preventivo e corretivo, normalmente aplicadas de forma difusa sobre a bacia, onde os prejuízos são reduzidos pela melhor convivência da população com as enchentes, podendo ser adotadas individualmente ou em grupo, espontaneamente ou por força de legislação e apóiam-se em aspectos sócio-políticos (exemplos: disciplinamento do uso e ocupação do solo, seguros, 
sistemas de alerta, incentivos fiscais, educação ambiental, participação pública, etc.)

A associação de medidas estruturais e não-estruturais certamente alcançará os melhores resultados (TUCCI, 1997) e (TUCCI, PORTO e BARROS, 1995). Rotineiramente, a abordagem da drenagem urbana já requer a adoção conjunta de medidas estruturais e não-estruturais por se tratarem de práticas complementares e interdependentes.

O custo de proteção através de medidas não-estruturais, normalmente, é inferior ao de medidas estruturais, mas nem por isso de mais fácil aplicação (PORTO e FILHO, 2004).

A solução ideal deve ser definida para cada caso distintamente, em função das características locais, dos benefícios alcançados, dos aspectos sociais e institucionais e dos impactos causados.

Segundo TUCCI e MARQUES (2001), “a maioria das soluções sustentáveis passam por medidas não-estruturais que envolvem restrições à população, e por isso, dificilmente um prefeito buscará este tipo de solução, que ao mesmo tempo frustra a população que espera por uma obra, uma medida estrutural, e interfere em interesses de proprietários, o que é politicamente complexo".

GRACIOSA (2004) reitera que há um certo desgaste do poder público ao implantar medidas não-estruturais em drenagem urbana porque a população habitualmente tende a reclamar da falta de obras hidráulicas para contenção de cheias.

A ANA (site) observa que a adoção destas medidas implica na necessidade de articulação crescente com outros sistemas de gestão urbana, que apesar de pertencerem à esfera de competência dos municípios, não facilitam essa tarefa. 


\subsubsection{Conceituação}

As medidas de controle de acordo com a conceituação envolvida são classificadas em (CANHOLI, 1995) e (TUCCI e MARQUES, 2000 e 2001) :

- soluções convencionais ou tradicionais: são aquelas relativas ao conceito clássico e tradicional de "canalização", com implantação de galerias e canais, retificação de córregos, etc., que proporcionam o rápido afastamento dos escoamentos, sendo amplamente utilizados até a presente data em todo o país;

- soluções não convencionais, alternativas ou compensatórias: são aquelas que utilizando principalmente os conceitos de armazenamento e infiltração, procuram equacionar os problemas de drenagem através da adequação e otimização dos sistemas, sem enfoque no rápido afastamento dos escoamentos, criando condições para aumentar o tempo de concentração, não agravar a situação de jusante e manter as condições pré-existentes.

Uma comparação entre as características dos conceitos de "canalização" e “armazenamento" foi desenvolvida por CANHOLI (1995) e é apresentada na tabela 4.

Segundo TUCCI, "a canalização custa de três a dez vezes mais do que a construção de reservatórios (contenção na origem) para resolver o mesmo problema" e "enquanto os países ricos verificaram que os custos de canalização e de condutos eram muito altos e abandonaram esse tipo de solução há mais de 30 anos, países pobres adotam sistematicamente essas medidas, perdendo duas vezes, com os custos maiores e com o aumento dos prejuízos" (FIORAVANTI, 2004). 
Tabela 4 - Canalização x Armazenamento

\begin{tabular}{|c|c|c|}
\hline Cara & Canalização & 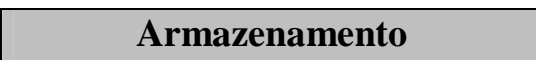 \\
\hline Função & $\begin{array}{ll}\text { - } & \text { remoção rápida dos } \\
& \text { escoamentos }\end{array}$ & $\begin{array}{ll}\text { - } & \text { contenção temporária para } \\
& \text { subseqüente liberação }\end{array}$ \\
\hline Componentes principais & - canais & $\begin{array}{ll}\text { - } & \text { reservatórios de superfície } \\
& \text { livres ou subterrâneos } \\
\text { - } & \text { retenção subsuperficial }\end{array}$ \\
\hline Aplicabilidade & 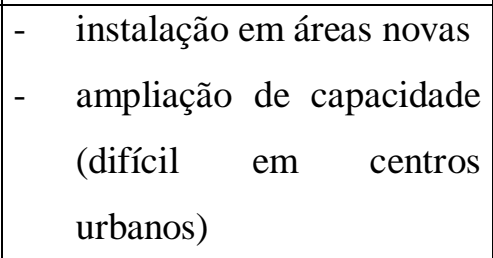 & $\begin{array}{lll}\text { - } & \text { áreas novas (em } \\
& \text { implantação) } \\
\text { - } & \text { áreas existentes (se houver } \\
& \text { áreas disponíveis) }\end{array}$ \\
\hline $\begin{array}{l}\text { Impacto à } \\
\text { (quantidade) }\end{array}$ & 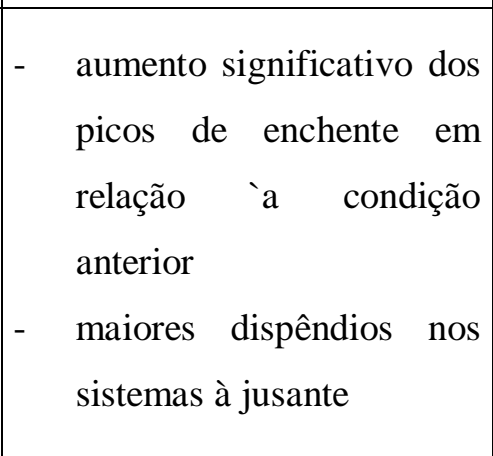 & $\begin{array}{l}\text { - } \text { áreas novas: pode ser } \\
\text { dimensionado para impacto } \\
\text { zero (legislação U.S.A. e } \\
\text { Reino Unido) } \\
\text { - } \text { reabilitação de sistemas: } \\
\text { vazões à jusante compatíveis } \\
\text { com a capacidade disponível }\end{array}$ \\
\hline $\begin{array}{lll}\text { Impacto à jusante } \\
\text { (qualidade) }\end{array}$ & 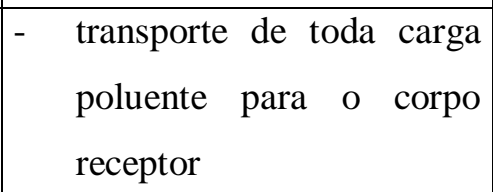 & $\begin{array}{ll}\text { - } & \text { facilita remoção de material } \\
& \text { flutuante e de sólidos } \\
& \text { suspensos (sedimentação) }\end{array}$ \\
\hline o/operação & $\begin{array}{ll}\text { - } & \text { manutenção na ocorrência } \\
\text { de assoreamento e } & \\
\text { deposição de lixo } \\
\text { - } & \text { difícil acessibilidade }\end{array}$ & $\begin{array}{ll}\text { - } & \text { necessita de limpeza e } \\
& \text { fiscalização periódicas } \\
\text { - } & \text { sistema de bombeamento } \\
& \text { eventual (operação) } \\
\text { - } & \text { desinfecção eventual } \\
& \text { (insetos) }\end{array}$ \\
\hline $\begin{array}{l}\text { Estudos } \\
\text { hidráulicos/hidrológi }\end{array}$ & $\begin{array}{ll}- & \text { definição dos picos de } \\
& \text { enchentes }\end{array}$ & $\begin{array}{ll}\text { - } & \text { definição dos hidrogramas e } \\
& \text { volumes das enchentes }\end{array}$ \\
\hline
\end{tabular}

(Fonte: Canholi,1995) 


\subsubsection{Local de intervenção}

As medidas de controle podem ainda ser classificadas conforme o local de atuação na bacia hidrográfica em (URBONAS e STAHRE, 1993) e (PORTO e FILHO, 2004):

- na fonte ou distribuídas: envolvem o controle no lote ou em qualquer área primária de desenvolvimento, atuando próximo à formação do escoamento superficial direto;

- a jusante: agem sobre os principais cursos d'água urbanos, nas bacias ou subbacias de contribuição, tratando de vazões de maior porte.

URBONAS e STAHRE (1993), TUCCI e MARQUES (2001) e PARKINSON et al (2003) observam que nos últimos anos, as medidas de controle na fonte, geralmente compostas por várias unidades de pequenas dimensões, vêm sendo consideravelmente reconhecidas e aceitas, e fazem as seguintes observações com relação a elas:

- proporcionam grande flexibilidade na escolha de locais para implantação das medidas de controle devido à dimensão das unidades;

- permitem a padronização de unidades de armazenamento;

- permitem a utilização mais eficiente dos sistemas de drenagem de jusante;

- dificultam o monitoramento dos projetos, das instalações e da conservação pelo grande número de pequenas unidades;

- podem ser altos os custos de manutenção e operação pela quantidade de unidades implantadas;

- a avaliação do desempenho global do conjunto de pequenas estruturas para fins de dimensionamento e projeto pode se tornar difícil e trabalhosa, sendo muitas vezes desconhecida ${ }^{5}$;

- distribuem o ônus da manutenção e operação com os usuários;

\footnotetext{
${ }^{5}$ Por esta razão, os americanos não as consideram no planejamento de macrodrenagem, segundo informações do Dr. Rubens Terra Barth.
} 
- permitem a redução de material sólido nos sistemas principais;

- reduzem a necessidade e as dimensões da rede de drenagem;

- são vistas como componentes viáveis do desenvolvimento urbano sustentável;

- multiplicam as alternativas possíveis de controle de cheias.

URBONAS (1999) relata que a impossibilidade de prever o grau de melhoramento causado pelo efeito cumulativo de numerosas estruturas de controle na fonte, se deve ao fato de serem projetados por profissionais diferentes, executados por outras empresas com níveis distintos de controle de qualidade e depois de instalados, serem operados e mantidos por diversos indivíduos de formas variadas.

MAKROPOULOS, BUTLER e MAKSIMOVIC (1999) esclarecem que apesar dos consideráveis esforços para quantificar os fenômenos envolvidos e para produzir diretrizes de aplicação, ainda há uma falta de metodologias fidedignas para sua implementação que levem em consideração as características específicas de cada local (localidades distintas podem ser beneficiadas de formas diferenciadas por uma ou outra medida de controle na fonte).

Normalmente, o uso de reservatórios de detenção na fonte ocorre em áreas já loteadas, enquanto que o reservatório na saída do loteamento é usado para futuros desenvolvimentos (TUCCI e MARQUES, 2001).

Relativamente as medidas de controle a jusante, que são constituídas por poucas unidades de grande porte, URBONAS e STAHRE (1993) fazem as seguintes considerações gerais:

- tem a vantagem da escala, reduzem os custos de construção, operação e manutenção se comparadas com o grande número de unidades de pequenas dimensões das medidas de controle na fonte;

- são mais fáceis de conservar e administrar, devido ao reduzido número de unidades;

- encontrar lugares apropriados para instalação pode ser trabalhoso;

- os custos de aquisição das terras são maiores; 
- a instalação de grandes barragens ou reservatórios podem encontrar oposição pública.

Segundo URBONAS e STAHRE (1993) não há um limite claro entre medidas de controle na fonte e a jusante, pois dependem do referencial adotado, havendo dispositivos que podem ser classificados das duas maneira, e assim apresentam a figura 12 para melhor elucidar esses limites.

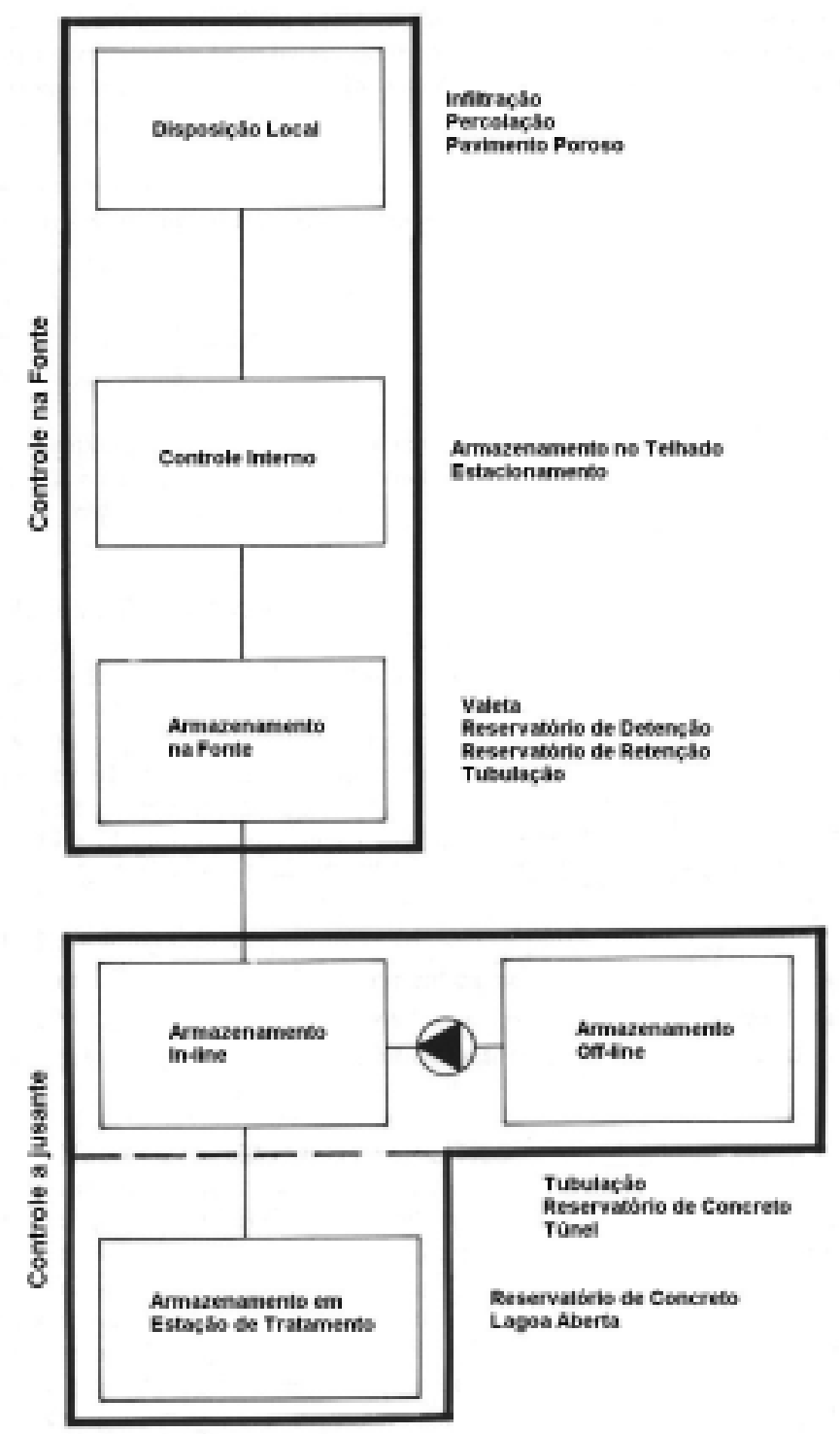

Figura 12 - Classificação dos dispositivos de armazenamento Fonte : Urbonas e Stahre (1993) 


\subsection{Aspectos da Qualidade da Água}

Por muito tempo acreditou-se que a poluição dos corpos d'água era decorrente de lançamentos de esgotos domésticos e industriais não tratados, visto que apenas 20,2\% dos municípios brasileiros coletam e tratam seus esgotos (IBGE, 2002). Hoje, sabe-se que parte dessa poluição tem origem no escoamento superficial gerado nos eventos de chuvas, sendo agravado pelos processos de urbanização.

A poluição gerada pelo escoamento superficial é conhecida como poluição difusa, uma vez que provém de atividades de diferentes agentes que depositam poluentes de forma esparsa sobre a área de contribuição da bacia hidrográfica, e seu controle é ponto crucial para a concepção e funcionamento dos sistemas de drenagem urbana, em especial estruturas alternativas.

“A poluição por cargas difusas se origina no ciclo hidrológico, com o arraste dos poluentes pelas precipitações e posterior transporte pelo escoamento superficial e, por esta razão, é um fenômeno de natureza aleatória como o próprio evento hidrológico que lhe dá origem" (PMSP/FCTH, 1999).

Esta poluição, que contém diversos poluentes como sólidos suspensos ou dissolvidos, metais pesados, óleos e graxas, bactérias, coliformes fecais, nutrientes em geral, etc, foi considerada nos Estados Unidos como a maior causa de poluição dos corpos d'água superficiais, a quarta maior causa de degradação da qualidade dos rios e a terceira maior fonte de degradação de lagos (NOVOTNY, 1993 apud OLIVEIRA, 2004).

A poluição difusa apresenta como características: seu caráter intermitente (relacionado à ocorrência de precipitação), a diversidade de sua composição (depende das atividades desenvolvidas na bacia de contribuição) e a impossibilidade de localização exata de suas origens.

As principais fontes geradoras das cargas difusas são (TUCCI, PORTO e BARROS, 1995) e (PMSP/FCTH, 1999):

- Deposição atmosférica: através da deposição seca (provenientes dos poluentes do ar que se depositam sobre telhados, ruas e demais superfícies urbanas e são posteriormente transportados pelo escoamento superficial) e da 
deposição úmida (gases e partículas presentes na atmosfera que se dissolvem ou são arrastados pelas águas e trazidas ao solo). "A noção da pureza da água da chuva é incorreta e, ao contrário, a chuva é um dos meios mais eficientes de remoção de poluentes atmosféricos" (PMSP/FCTH, 1999);

- Desgastes da pavimentação: partículas ou pedaços de asfalto, cimento ou outro material utilizado na pavimentação que se desprendem com o uso;

- Veículos: junto com as indústrias são as principais fontes de poluição do ar, além de contribuírem com derrame de combustível, óleo lubrificante, partículas que se soltam com o desgaste dos pneus, etc. e apesar de não serem responsáveis por grandes quantidades, são os mais tóxicos;

- Restos de vegetação, lixo, poeira, restos e dejetos de animais: aparecem em grandes quantidades e são a principal fonte de obstrução dos sistemas de drenagem;

- Derramamentos: provenientes de eventos aleatórios, produzem grandes quantidades de cargas tóxicas passíveis de transporte pelas águas de chuva;

- Erosão: gerador da maior parte dos sedimentos presentes nos corpos hídricos, carregam também uma variedade de poluentes adsorvida à superfície de suas partículas, particularmente os orgânicos derivados do petróleo, metais pesados e fosfatos não dissolvidos.

As consequiências trazidas por essas cargas difusas aos corpos hídricos são (TUCCI, PORTO e BARROS, 1995) (PMSP/FCTH, 1999):

- Alterações estéticas;

- Deposição de sedimentos;

- Depleção da concentração de oxigênio dissolvido;

- Contaminação por organismos patogênicos;

- Eutrofização;

- Danos devido à presença de tóxicos. 
"O uso e ocupação do solo na bacia são fatores determinantes na geração da carga difusa, tanto no que se refere às concentrações dos diversos poluentes, como na forma com que a carga aflui ao corpo d'água" (BARROS, 2004).

A concentração de poluentes presentes no escoamento superficial varia ao longo do tempo, assim como variam as vazões, e é representada pela figura 13 , denominada de polutograma.

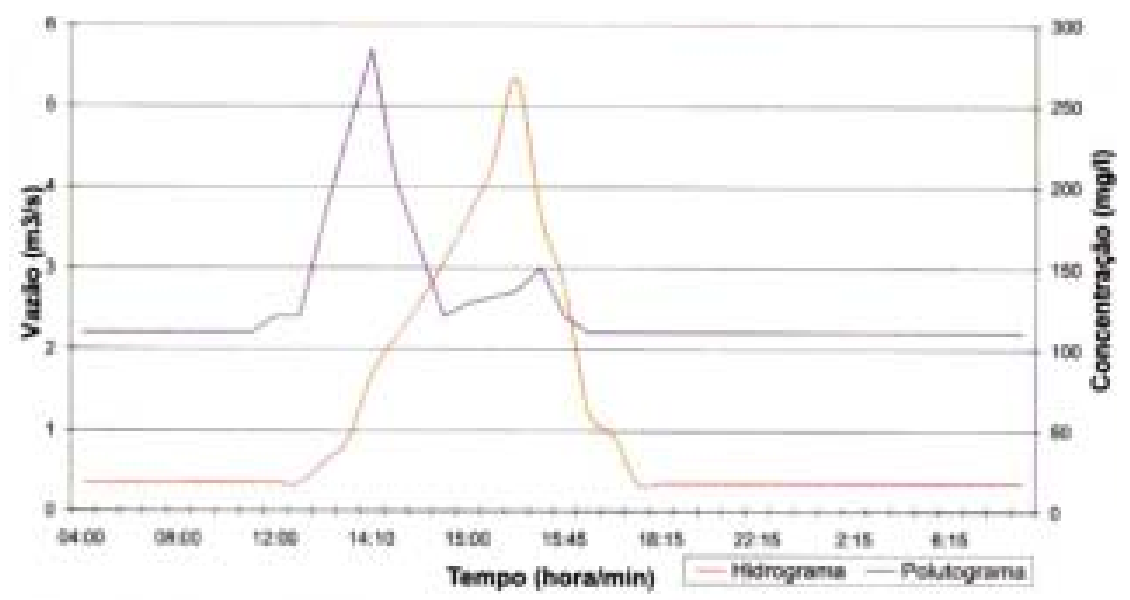

Figura 13 - Polutograma da DBO

Fonte: Barros (2004)

Nesta figura, nota-se a ocorrência da chamada "carga de lavagem", "first flush" ou "wash load" que explica a ocorrência do pico do polutograma antes do pico do hidrograma, caracterizando a remoção de boa parte dos poluentes dispersos sobre as superfícies logo no início das chuvas. Ressalta-se porém, que este fenômeno nem sempre ocorre, variando basicamente em função do intervalo entre os eventos de chuva e das características da bacia.

Outra consideração importante é o fato de que quando o interesse é na redução da quantidade de água, o embasamento é feito em eventos raros que geram grandes volumes de escoamento e quando o interesse é na melhoraria da qualidade da água, eventos de grande magnitude são pouco importantes por sua capacidade de diluição dos poluentes, sendo fundamental então, controlar eventos freqüentes de menor impacto, que sistematicamente lançam cargas difusas nos corpos d'água (OLIVEIRA, 2004). 
O controle da poluição difusa pode ser realizado através de (TUCCI, PORTO e BARROS, 1995) e (PMSP/FCTH, 1999):

- Controle do uso do solo urbano;

- Licenciamento de atividades geradoras de poluição, inclusive aquelas potenciais produtoras de sedimentos como a construção civil;

- Manutenção e criação de áreas verdes;

- Controle de ligações clandestinas de esgoto;

- Varrição de ruas;

- Controle da coleta e disposição final do lixo;

- Educação da população;

- Medidas estruturais.

As medidas estruturais para redução da poluição difusa utilizam principalmente, os mecanismos da sedimentação, filtração, infiltração e remoção biológica para alcançar seus objetivos (TUCCI, PORTO e BARROS, 1995) e (PMSP/FCTH, 1999).

A eficiência de algumas das estruturas utilizáveis para essa finalidade pode ser observada na tabela 5, porém outros fatores como a topografia local, o tamanho da bacia de contribuição, a permeabilidade do solo, o tipo de ocupação urbana, etc, devem também ser considerados na seleção da melhor alternativa.

A Companhia de Saneamento Ambiental de Brasília - CAESB, que vem desenvolvendo um programa de despoluição do Lago Paranoá, considera que, apesar do elevado nível de tratamento de esgotos existente nesta bacia, tal tratamento sozinho não garantirá a qualidade da água, havendo a necessidade de controlar o aporte de impurezas provenientes do escoamento superficial.

Como este tende a se tornar cada vez mais o maior responsável pela qualidade da água no lago, foi elaborado por este órgão, um informativo denominado "Medidas para controle do escoamento superficial na Bacia do Lago Paranoá”, que busca sensibilizar a população a adotar alternativas preventivas e assim reduzir o aporte da poluição difusa durante eventos de chuvvas (CAESB, 2003). 
Essa preocupação demonstra que, onde já existe tratamento dos efluentes domésticos e industriais, o escoamento superficial gerado pelas águas das chuvas torna-se a principal fonte poluidora dos corpos d'água.

Tabela 5 - Matriz de avaliação da eficiência das BMPs

\begin{tabular}{|l|l|l|l|l|l|}
\hline \multirow{2}{*}{ Alternativa de controle } & \multicolumn{5}{|c|}{ Porcentagem de remoção } \\
\cline { 2 - 6 } & $\begin{array}{l}\text { Sólido em } \\
\text { suspensão }\end{array}$ & $\begin{array}{l}\text { Fósforo } \\
\text { total }\end{array}$ & $\begin{array}{l}\text { Nitrogênio } \\
\text { total }\end{array}$ & Zinco & Bactéria \\
\hline $\begin{array}{l}\text { Minimização de áreas } \\
\text { conectadas }\end{array}$ & $\mathrm{Nd}$ & $\mathrm{Nd}$ & $\mathrm{Nd}$ & $\mathrm{Nd}$ & $\mathrm{Nd}$ \\
\hline Faixas gramadas & $10-20$ & $0-10$ & $0-10$ & $0-10$ & $\mathrm{Nd}$ \\
\hline Valetas gramadas & $20-40$ & $0-15$ & $0-15$ & $0-20$ & $\mathrm{Nd}$ \\
\hline Bacias de detenção & $50-70$ & $10-20$ & $10-20$ & $30-60$ & $50-90$ \\
\hline Bacias de retenção & $60-95$ & $0-80$ & $0-80$ & $0-70$ & $\mathrm{Nd}$ \\
\hline Alagadiços & 40 & $9-60$ & $9-60$ & 60 & $\mathrm{Nd}$ \\
\hline Pavimentos porosos & $80-95$ & 65 & 65 & 99 & $\mathrm{Nd}$ \\
\hline
\end{tabular}

(Fonte: Urban Drainage and Flood Control District, 1995 apud PMSP/FCTH, 1999)

$\mathrm{Nd}=$ não disponível

$\mathrm{Na}$ implantação das estruturas alternativas, a qualidade da água torna-se importante parâmetro para garantir o funcionamento adequado dos sistemas e para adoção de medidas apropriadas que evitem poluentes indesejáveis, e assim, condicionam e limitam a concepção destes dispositivos.

Ao mesmo tempo, ganham relevância quando há a disposição para utilização da água para outras finalidades, além de permitir um maior controle sobre as atividades ocorridas na bacia e sinalizar irregularidades.

NETTO (2003) observa que "o problema da qualidade da água da drenagem urbana se acentua no país e deve começar a ser tratado de forma mais sistematizada”. 


\subsection{Legislação}

A legislação deve ser clara, precisa, concisa e abrangente, adequando-se às necessidades e aos interesses coletivos, e fruto da real necessidade de regular, mitigar ou prevenir conflitos que no convívio social não puderam ser resolvidos adequadamente ou que são passíveis de confronto.

Ao mesmo tempo, em função das características continentais do Brasil, das desigualdades internas e da diversidade de ecossistemas, a legislação deve atender às peculiaridades regionais do meio ambiente e da população, além de ser estabelecida de forma a ser prontamente cumprida.

A demanda por novas leis e o aperfeiçoamento das existentes só são avaliados com precisão a partir da prática e da vivência diária nas tentativas de implantação, entretanto, falta de praticidade e funcionalidade fazem com que muitas leis deixem de ser obedecidas e o esforço e desgaste despendidos na elaboração de novas leis são muitas vezes desperdiçados pela falta de mecanismos voltados para a real concretização dos efeitos esperados (COSTA e SANTOS, 1999).

A aplicação da lei, na prática da gestão urbana, é regulada por um conjunto de normas emitidas pela autoridade administrativa e em um país fértil em leis que "não pegam", a base administrativa e de fiscalização com que conta essa autoridade para fazer cumprir a lei pode definir se esta será aplicada ou não, e são claros indicadores da disposição da autoridade em aplicá-la (CBH-AT, 2002).

"O texto de lei que tem sua aplicação inviabilizada, seja pela ausência de estrutura administrativa, seja por procedimentos inadequados ou mesmo pela vontade política de não aplicá-lo, não está em vigor de fato”. Assim como a fiscalização do cumprimento efetivo de um dispositivo que consta de um texto legal, que se revelar na prática tecnicamente inviável, anula sua presença no texto da lei (CBH-AT, 2002).

GRANZIERA, 1993 apud COSTA e SANTOS, 1999 e PARKINSON et al, 2003, concluíram que não é a ausência de normas a causa do estado lastimável dos corpos d'água no Brasil, mas a estrutura institucional e a falta ou dificuldade de fiscalização e punição efetiva dos infratores, além da demora na implantação das leis. 
As cheias urbanas, como causadoras de grandes impactos sobre a sociedade, estão devidamente contempladas na Constituição da República Federativa do Brasil ${ }^{6}$, que institui à União a competência para "planejar e promover a defesa permanente contra as calamidades públicas, especialmente secas e inundações”. A Política Estadual de Recursos Hídricos do Estado de São Paulo ${ }^{7}$, também reforça a necessidade de "combate e prevenção das causas e dos efeitos adversos da poluição, das inundações, das estiagens, da erosão do solo e do assoreamento dos corpos d'água". E assim como São Paulo, outros estados, municípios e a sociedade em geral também reconhecem a importância desses impactos e a necessidade de preveni-los (TUCCI e MARQUES, 2000 e 2001).

Desta forma, a legislação brasileira vem criando normas e regulamentos que procuram atender às ansiedades da sociedade e, ao mesmo tempo, organizar e articular ações na área de recursos hídricos. Porém, a crescente conscientização da importância da preservação e do valor econômico da água tem suscitado uma série de conflitos de interesses e questões filosóficas delicadas, que tornam o arcabouço jurídico, terreno fértil para diferenciadas posturas e interpretações, demonstrando a necessidade de aperfeiçoamento do sistema.

"O conjunto de textos legais funciona como um todo e assim deve ser visto" (COSTA e SANTOS,1999). Porém, "é próprio do uso de recursos naturais e do ambiente construído comum que metas setoriais apresentem conflitos entre si e que, dentro de um mesmo plano setorial, as metas de âmbito local colidam com as de âmbito supra-local" (CBH-AT, 2002).

Diversos órgãos da Administração Pública Federal e dos Estados possuem competências no gerenciamento das águas, e por esta razão, questões relativas aos recursos hídricos exigem bom senso das partes envolvidas, no sentido de promover sua melhor gestão, sobrepondo à busca da interpretação normativa com foco nos consectários da dominialidade (CUNHA, VEIGA e KELMAN, 2004).

É vital evitar a deturpação das normas gerais e garantir a fiscalização para que as leis definidas no papel, sejam efetivamente cumpridas por todos. Entretanto, somente uma regulamentação sólida e uma estrutura institucional organizada, serão capazes de avalizar essas metas (COSTA e SANTOS, 1999).

\footnotetext{
${ }^{6}$ artigo 21 , inciso XVIII.
} 
“A ação coordenada entre os poderes federal, estadual e municipal é essencial para se implantar uma drenagem urbana sustentável. A solução dos problemas está na criação e estabelecimento de uma estrutura organizacional e institucional sólida, efetiva e perene de recursos financeiros para administrar ações de maneira independente de questões políticas e de forma sintonizada com os interesses efetivos que se quer dar" (PARKINSON et al, 2003).

Duas questões básicas advém da legislação existente: a gestão territorial relacionada com a dominialidade dos recursos hídricos e a questão institucional, ligada às diferentes esferas envolvidas com a gestão das águas. E a essas duas questões, relacionam-se os instrumentos de gestão e os mecanismos de consenso.

Não sendo esse assunto o foco principal deste trabalho e diante da grandiosidade de suas questões, apresentar-se-á, de forma bastante sucinta e não extensiva, dividido em três grandes blocos (federal, estadual e municipal), a abordagem existente em algumas das legislações em vigor para que se possa vislumbrar as possibilidades, as restrições e os encaminhamentos possíveis.

$\mathrm{Na}$ esfera federal, será abordada a Constituição Federal, a Política Nacional de Recursos Hídricos conjuntamente com o Sistema Nacional de Gerenciamento e Recursos Hídricos e o Estatuto da Cidade; na esfera estadual, a Constituição do Estado de São Paulo e a Política Estadual de Recursos Hídricos com o Sistema Integrado de Gerenciamento de Recursos Hídricos; na esfera municipal, será feita apenas uma abordagem geral de aspectos pertinentes a estas questões.

\footnotetext{
${ }^{7}$ Lei estadual $n^{\circ} 7663 / 91$, artigo $3^{\circ}$, inciso V.
} 


\subsubsection{Federal}

\subsubsection{Constituição da República Federativa do Brasil}

A Constituição da República Federativa do Brasil ${ }^{8}$, institui como bens da União 9 , "os lagos, rios e quaisquer correntes de água em terrenos de seu domínio, ou que banhem mais de um Estado, sirvam de limites com outros países, ou se estendam a território estrangeiro ou dele provenham, bem como os terrenos marginais e praias fluviais" e como bens dos Estados ${ }^{10}$, "as águas superficiais ou subterrâneas, fluentes, emergentes e em depósito, ressalvadas, neste caso, na forma da lei, as decorrentes de obras da União".

Segundo o entendimento de CUNHA, VEIGA e KELMAN (2004), "a Constituição não inclui explicitamente os rios dentro do rol de bens dos Estados, porém por tradição, os governos estaduais têm exercido absoluta competência administrativa nos rios que têm foz e nascente em seu território, mesmo quando esses rios desembocam em outros rios que fluem em direção a outros estados. Essa competência administrativa estadual entretanto, é exercida de forma relativa e não absoluta, condicionada por parâmetros e critérios decididos para cada bacia hidrográfica.

Ainda sob o ponto de vista da competência administrativa, a norma constitucional indica a competência da União para "instituir sistema nacional de gerenciamento de recursos hídricos e definir critérios de outorga de direito de uso" ${ }^{11}$. No que tange à competência formal ${ }^{12}$, determina a competência privativa da União para legislar sobre águas e ressalva que aos Estados a permissão para legislar sobre esse assunto somente se dará através de autorização formalizada por lei complementar $^{13}$ (CUNHA, VEIGA e KELMAN, 2004).

\footnotetext{
${ }^{8}$ promulgada em 5 de outubro de 1988.

9 artigo 20 , inciso III

${ }^{10}$ artigo 26, inciso I.

11 artigo 21, inciso XIX.

12 artigo 22, inciso IV.

${ }^{13}$ Artigo 22, parágrafo único.
} 
Desta forma, cumpre à União estabelecer uma determinação indispensável e estratégica para a Federação, visto que é sua a incumbência de promover o interesse geral do Estado brasileiro”. (CUNHA, VEIGA e KELMAN, 2004).

Para CUNHA, VEIGA e KELMAN (2004), apesar de estarem bem claras as premissas instituídas pela Constituição para "os direcionamentos diferenciados dados aos institutos jurídicos, dominialidade e competência, e aos papéis dos entes federados", observa-se que "os comandos constitucionais não têm sido bem assimilados, causando uma série de desencontros políticos, jurídicos e administrativos, com retardo e desvios na gestão da água no Brasil”.

Ressalva-se que a tese acima defendida não é compartilhada por todos que militam na área, pois alguns juristas entendem que o ente que detém o domínio também tem a competência para indicar regras dentro de seu quinhão territorial (CUNHA, VEIGA e KELMAN, 2004).

Porém, há que se considerar ainda que as competências instituídas para legislar sobre as águas e administrar este bem são distintas na vertente ambiental, onde tem-se a competência comum de todos os entes federados para proteger o meio ambiente e combater a poluição ${ }^{14}$, e a competência concorrente dos mesmos, exceto dos municípios, para legislar sobre a defesa dos recursos naturais, proteção do meio ambiente e controle da poluição ${ }^{15}$.

A Constituição esclarece que a competência da União para legislar sobre normas gerais na vertente ambiental, não exclui a competência suplementar dos Estados e que "inexistindo lei federal sobre normas gerais, os Estados exercerão a competência legislativa plena, para atender as suas peculiaridades", ressaltando que "a superveniência da lei federal sobre normas gerais suspende a eficácia da lei estadual, no que lhe for contrário" ${ }^{\text {. }}$.

No que tange a competência comum da União, Estados, Distrito Federal e Municípios, as normas de cooperação serão fixadas através de Lei Complementar, tendo em vista o equilíbrio e o bem-estar em âmbito nacional ${ }^{17}$.

\footnotetext{
${ }^{14}$ Artigo, 23, inciso VI.

${ }^{15}$ Artigo 24, inciso VI.

${ }^{16}$ Artigo $24, \S 2^{\circ}, \S 3^{\circ}$ e $\$ 4^{\circ}$.

17 Artigo 23, parágrafo único.
} 
Aos Municípios compete legislar sobre assuntos de interesse local, suplementar à legislação federal e à estadual no que couber e principalmente, promover adequado ordenamento territorial, mediante planejamento e controle do uso, do parcelamento e da ocupação do solo urbano ${ }^{18}$.

Conclui-se portanto, que em matéria de águas, a competência privativa e a competência concorrente cruzam-se e permanecem entrelaçadas (CUNHA, VEIGA e KELMAN, 2004), impondo-se ao poder público e à coletividade o dever de defender e preservar o meio ambiente para as presentes e futuras gerações ${ }^{19}$.

\subsubsection{Política Nacional de Recursos Hídricos e Sistema Nacional de Gerenciamento de Recursos Hídricos}

A Política Nacional de Recursos Hídricos (PNRH) e Sistema Nacional de Gerenciamento de Recursos Hídricos (SINGREH) foram instituídos pela Lei $n^{\circ} 9433$ de 8 de janeiro de 1997, regulamentando o inciso XIX, do artigo 21, da Constituição Federal.

“A PNRH configura-se na oportunidade de discussão de uma organização institucional específica para coordenar todas as atividades da gestão de recursos hídricos, incluindo o setor de planejamento da drenagem urbana e o controle de cheias" (MARIN et al, 1999).

Os princípios básicos desta lei, são comuns à lei estadual paulista que a antecedeu, havendo também o reconhecimento do valor econômico da água e de seu domínio público. Como instrumentos de gestão ${ }^{20}$ tem-se: os planos de recursos hídricos, a outorga de direito de usos da água, a cobrança pelo uso da água, o enquadramento dos corpos d'água e o sistema de informações sobre recursos hídricos.

O Plano de Recursos Hídricos elaborado por bacia hidrográfica, por estado e para o País ${ }^{21}$, é o instrumento de gestão da PNRH que visa fundamentar e orientar a implementação dessa Política e estabelecer as bases para o gerenciamento integrado,

\footnotetext{
${ }^{18}$ Artigo 30, incisos I, II e VIII.

${ }^{19}$ Artigo 225, caput.

${ }^{20}$ Artigo $5^{\circ}$.
} 
descentralizado e participativo dos recursos hídricos, procurando adequar-se às grandes diversidades regionais (PARKINSON, 2003).

Ele é o instrumento central da PNRH por fazer uso do sistema de informações sobre recursos hídricos e do enquadramento dos corpos d'água como insumos para sua elaboração e, ao mesmo tempo, por servir de base para a efetivação da outorga e da cobrança pelo uso da água.

A adoção da Bacia Hidrográfica como unidade de planejamento ${ }^{22}$ consiste num importante fundamento da PNRH, pois ultrapassando a divisa territorial de cada ente da federação, determina uma nova área de abrangência para legislação dos recursos hídricos. Isso significa que no território de um único ente federado poderão vigorar diferentes legislações, o que é complexo de se administrar, podendo trazer desconforto para o governante e descontentamento à população.

Amenizando as questões decorrentes da adoção da Bacia Hidrográfica como unidade de gestão, a PNRH fundamenta-se também na gestão descentralizada dos recursos hídricos com a participação do Poder público, dos usuários e das comunidades $^{23}$ e determina que a União e os Estados devem se articular para gerenciar os recursos hídricos de interesse comum, ou seja, devem atuar harmonicamente e complementarmente através de um sistema unificado específico para cada bacia hidrográfica ${ }^{24}$.

"Isto significa que nenhum Estado da federação deve unilateralmente tomar decisão administrativa que prejudique a disponibilidade hídrica, em termos quantitativos e qualitativos ${ }^{25}$, para cidadãos de outros estados ou em desacordo com os critérios estabelecidos pela União", estando impedidos de administrar as águas de seu domínio apenas com regras próprias, apesar de ser sua a responsabilidade de coibir usos em desacordo com os referidos critérios (CUNHA, VEIGA e KELMAN, 2004).

Aos Municípios e ao Distrito Federal cabe segundo a PNRH, a promoção da integração das políticas locais de saneamento básico, de uso, ocupação e conservação

\footnotetext{
21 artigo $8^{\circ}$.

${ }^{22}$ Artigo $1^{\circ}$, inciso V.

23 artigo $1^{\circ}$, inciso VI.

24 Artigo 4.

25 Constitui-se diretriz geral de ação para implementação da PNRH, a gestão sistemática, sem dissociação dos aspectos de quantidade e qualidade.
} 
do solo e do meio ambiente com as políticas federal e estaduais de recursos hídricos ${ }^{26}$.

O SINGREH, criado pela PNRH, tem como objetivos coordenar a gestão integrada das águas; arbitrar administrativamente os conflitos relacionados com os recursos hídricos; implementar a PNRH; planejar, regular e controlar o uso, a preservação e a recuperação dos recursos hídricos e promover a cobrança pelo uso de recursos hídricos, e é composto pelo Conselho Nacional de Recursos Hídricos CNRH; Agência Nacional de Águas - ANA $^{27}$; Conselhos de Recursos Hídricos dos Estados e do Distrito Federal; Comitês de Bacia Hidrográfica; órgãos dos poderes públicos federal, estaduais, do Distrito Federal e municipais cujas competências se relacionem com a gestão de recursos hídricos e as Agências de Água.

$\mathrm{O}$ CNRH que possui, entre outras competências ${ }^{28}$, a arbitragem, em última instância, dos conflitos existentes entre Conselhos Estaduais de Recursos Hídricos e o estabelecimento de diretrizes complementares para implantação da PNRH, deliberou que na formulação das diretrizes de implantação da PNRH deverá ser considerada a interdependência das águas superficiais, subterrâneas e meteóricas, visto que são partes integrantes e indissociáveis do ciclo hidrológico ${ }^{29}$.

Outra deliberação do CNRH determinou que, face a necessidade urgente de serem elaborados e implementados Planos de Recursos Hídricos em bacias hidrográficas onde ainda não foram criados Comitês de Bacias e/ou Agências de Água ou de bacias, estes poderão ser elaborados pelas entidades ou órgãos gestores de recursos hídricos, de acordo com a dominialidade das águas, sob supervisão e aprovação dos respectivos Comitês de Bacias. Caso não haja Comitês de Bacias, as competentes entidades ou os órgãos gestores de recursos hídricos serão responsáveis, com a participação dos usuários de água e das entidades civis de recursos hídricos, pela elaboração da proposta do Plano, bem como pela implementação de ações necessárias à criação do respectivo comitê, que será responsável pela aprovação do referido plano $^{30}$.

\footnotetext{
${ }^{26}$ Artigo 31.

${ }^{27}$ Entidade federal de implementação da PNRH, integrante do SINGREH, criada pela Lei no 9984 de 17 de julho de 2000.

${ }^{28}$ Artigo 35.

${ }^{29}$ Resolução $\mathrm{n}^{\mathbf{0}} 15$, de 11 de janeiro de 2001.

${ }^{30}$ Resolução no 17 , de 29 de maio de 2001.
} 
Adicionalmente, o CNRH estabeleceu que os Planos de Recursos hídricos deverão levar em consideração os planos, programas, projetos e demais estudos relacionados a recursos hídricos existentes na área de abrangência das respectivas bacias, não podendo o Plano de uma sub-bacia ser aprovado se as condições do seu exutório não estiverem compatibilizadas com o Plano da bacia hidrográfica principal.

A ANA foi criada com a finalidade de implementar a $\mathrm{PNRH}^{31}$, cabendo-lhe planejar e promover ações destinadas a prevenir ou minimizar os efeitos de secas e inundações, no âmbito do SINGREH, em articulação com o órgão central do Sistema Nacional de Defesa Civil, em apoio aos Estados e Municípios. Cabe a ela também, estimular a pesquisa e a capacitação de recursos humanos para a gestão de recursos hídricos; prestar apoio aos Estados na criação de órgãos gestores de recursos hídricos e propor ao CNRH, o estabelecimento de incentivos, inclusive financeiros, à conservação qualitativa e quantitativa de recursos hídricos ${ }^{32}$.

Os comitês de bacias hidrográficas têm, entre outras, as atribuições de: promover o debate das questões relacionadas aos recursos hídricos da bacia; articular a atuação das entidades que trabalham com o tema; arbitrar, em primeira instância, os conflitos relacionados a recursos hídricos; aprovar e acompanhar a execução do Plano de Recursos Hídricos da Bacia; estabelecer os mecanismos de cobrança pelo uso de recursos hídricos e sugerir os valores a serem cobrados; estabelecer critérios e promover rateio de custos das obras de usos múltiplos, de interesse comum ou coletivo $^{33}$.

Os Comitês de Bacia Hidrográfica, segundo o texto da lei, terão como área de atuação a totalidade de uma bacia hidrográfica; sub-bacias hidrográfica de tributário do curso de água principal da bacia ou tributário desse tributário, ou grupo de bacias ou sub-bacias hidrográficas contíguas ${ }^{34}$. Na prática, questões administrativas relacionadas à diversidade, complexidade e dimensão das bacias hidrográficas é que condicionarão a fusão ou a sub-divisão de cada uma delas, observando que não existem regras definidas, além do crivo dos Conselhos de Recursos Hídricos.

CUNHA, VEIGA e KELMAN (2004) observam que "nenhum texto legal regulamenta a forma como deve se dar a articulação em bacias hidrográficas

\footnotetext{
31 Artigo $3^{\circ}$.

32 Artigo $4^{\circ}$.

${ }^{33}$ Artigo 38.
} 
nacionais, composta por rios de diferentes domínios e esclarecem que a ANA, contribuindo para o estabelecimento da articulação da ação governamental à luz do texto constitucional, propôs e está implementando uma estratégia para avançar nesta questão, através da construção de acordos sociais estabelecidos nos comitês de bacia hidrográfica, visando a formação de consensos sobre a utilização dos recursos hídricos e evitando assimetrias entre usuários ou entre Estados.

As Agências de Águas, criadas por solicitação de um ou mais Comitês de Bacia Hidrográfica, devem exercer a função de secretária executiva do respectivo ou respectivos Comitês de Bacia Hidrográfica, condicionada a existência de viabilidade financeira assegurada pela cobrança do uso dos recursos hídricos em sua área de atuação ${ }^{35}$.

Como agente técnico e financeiro dos Comitês de Bacia Hidrográfica, suas competências $^{36}$ são conhecer os atributos técnicos da sua área de atuação, promover estudos necessários para a gestão dos recursos hídricos, elaborar o Plano de Recursos Hídricos para apreciação do Comitê de Bacia Hidrográfica e gerar e administrar os passivos financeiros das atividades relacionadas aos recursos hídricos da bacia.

O grande entrave à criação das Agências de Bacia é sua vinculação ao início da cobrança pelo uso dos recursos hídricos ${ }^{37}$, assunto polêmico e ainda não devidamente equacionado na grande maioria das bacias hidrográficas, retardando a instituição de uma entidade com características executivas, que pode vir a solucionar parte dos problemas hoje enfrentados na gestão dos recursos hídricos, pois praticamente todos os órgãos previstos nas legislações de recursos hídricos, são voltados para a elaboração de planos e programas, coordenação e articulação das ações, ficando as tarefas executivas para os demais órgãos e entidades das diversas esferas administrativas.

\footnotetext{
34 Artigo 37.

${ }^{35}$ Respectivamente artigos 41, 42 e 43.

${ }^{36}$ Artigo 44.

${ }^{37}$ Artigo 43, inciso $2^{\circ}$.
} 


\subsubsection{Estatuto Da Cidade}

O Estatuto da Cidade $^{38}$ é o principal instrumento gerado para incentivar o correto planejamento das cidades e contém uma série de diretrizes e instrumentos jurídicos e urbanísticos que têm o poder de intervir fortemente sobre o espaço urbano. Sua finalidade ${ }^{39}$ é estabelecer normas de ordem pública e interesse social que regulam o uso da propriedade urbana em prol do bem coletivo, da segurança e do bem-estar dos cidadãos, bem com do equilíbrio ambiental, garantindo o direito a cidades sustentáveis, à gestão democrática e à justa distribuição dos benefícios e ônus decorrentes do processo de urbanização ${ }^{40}$.

Desta forma, o Estatuto veio induzir e acelerar o processo de planejamento das cidades e cooperar na organização do crescimento dos Municípios para que estes alcancem um desenvolvimento mais harmônico e sustentável.

"No entanto, a simples existência dessa lei não garante a democratização e um maior equilíbrio sócio-ambiental para as cidades brasileiras. Para que isso efetivamente aconteça, é necessário que suas premissas saiam do texto da lei e adentrem as práticas de planejamento e gestão urbana e - principalmente - sejam incorporadas ao cotidiano dos cidadãos" (ESTATUTO DA CIDADE, site).

Os Planos Diretores, como instrumento legítimo de planejamento das cidades, são solicitados tanto pelo Estatuto da Cidade, como pela Constituição Federal, para certas categorias de municípios ${ }^{41}$.

Apesar de não haver obrigatoriedade de elaboração de Planos Diretores por Municípios com menos de 20.000 habitantes pela Constituição Federal, a decisão do governo federal de facilitar financiamentos para municípios que tenham esses Planos, é uma forma acertada de inclusão de todos os municípios e de mudança de realidade, promulgando o planejamento como meio de orientar o crescimento e prevenir problemas futuros, além de garantir seus investimentos. Nenhum município, por menor que seja, pretende perder a oportunidade de obter um financiamento do governo federal ao deixar de elaborar e implantar um Plano Diretor.

\footnotetext{
${ }^{38}$ promulgado pela lei federal $\mathrm{n}^{\circ} 10.257$ de 10 de junho de 2001 e que regulamenta os artigos $182 \mathrm{e}$ 183 da Política Urbana, presentes na Constituição Federal de 1988.

${ }^{39}$ Artigo $1^{\circ}$, parágrafo único.

${ }^{40}$ Artigo 2, incisos I, II e IX.

${ }^{41}$ Artigo 41 da Lei 10.257/01 e artigo 182, § $1^{\circ}$, da Constituição Federal.
} 
Há no Estatuto da Cidade, um prazo de cinco $\operatorname{anos}^{42}$ para que os municípios por ele enquadrados ${ }^{43}$ aprovem seus Planos Diretores, restando portanto, menos de 1 ano para a data limite. Porém esta não é uma tarefa fácil e são poucos os Municípios que já alcançaram essa meta. A participação pública, a articulação de órgãos distintos, o consenso entre as diversas vertentes e a falta de preparo de seus elaboradores são ainda desafios a serem vencidos.

Para TUCCI e MARQUES (2000), os municípios estão sendo pressionados a estabelecer os Planos Diretores e estes, na sua quase totalidade, não contemplam os aspectos de prevenção contra a ocupação dos espaços de risco de enchentes, apesar de já possuírem aspectos de preservação ambiental, e atribuem esta limitação a falta de conhecimento e orientação de seus elaboradores.

O Estatuto da Cidade, à rigor, não apresenta nenhum instrumento novo de aplicação direta no controle e prevenção de cheias, além do já conhecido planejamento. Entretanto, traz em seu conteúdo, instrumentos que utilizados com discernimento e criatividade podem gerar resultados positivos para a questão das inundações urbanas, como por exemplo, a instituição de unidades de conservação e zonas especiais de interesse social, o direito de superfície ${ }^{44}$, o direito de preempção ${ }^{45}$, a outorga onerosa do direito de construir e de alteração de uso ${ }^{46}$, e as operações urbanas consorciadas ${ }^{47}$.

PARKINSON (2003) por exemplo, considera que o Estatuto da cidade institui medidas jurídicas para a questão da adoção das medidas não estruturais na drenagem, citando o direito de preempção.

\footnotetext{
42 Artigo 50.

43 inciso I (mais de 20.000 habitantes) e II (integrantes de regiões metropolitanas e aglomerações urbanas) do art. 41, além daqueles situados em áreas de especial interesse turístico, integrantes das áreas de influência de empreendimentos com impacto ambiental ou que queiram implementar os instrumentos previstos no Estatuto.

${ }^{44}$ Artigo 21. Abrange o direito de utilizar o solo, o subsolo ou o espaço aéreo relativo ao terreno, na forma estabelecida no contrato respectivo e atendida a legislação urbanística.

${ }^{45}$ Artigos 25. instrumento que facilita a aquisição, por parte do poder público, de áreas de interesse, para a realização de projetos específicos, como o ordenamento e direcionamento da expansão urbana e a criação de espaços públicos de lazer e áreas verdes.

${ }^{46}$ Artigo 28. O direito de construir poderá ser exercido acima do coeficiente de aproveitamento básico adotado, mediante contrapartida a ser prestada pelo beneficiário.

${ }^{47}$ Artigo 32. Conjunto de intervenções e medidas coordenadas pelo Poder Público municipal, com a participação dos proprietários, moradores, usuários permanentes e investidores privados, com o objetivo de alcançar em uma área transformações urbanísticas estruturais, melhorias sociais e a valorização ambiental.
} 


\subsubsection{Estadual}

Atualmente na esfera estadual, 18 Estados e o Distrito Federal já instituíram suas políticas e sistemas estaduais de gerenciamento de recursos hídricos e de forma geral, incluem como organismos integrantes o Conselho Estadual, os Comitês de Bacia e o órgão público gestor, composto predominantemente pelas Secretarias Estaduais (ANA, site).

$\mathrm{Na}$ impossibilidade de analisar todas as legislações estaduais de recursos hídricos existentes, optou-se por comentar aquela referente ao Estado de São Paulo, por incorporar o universo dos estudos de casos apresentados e por ter antecedido a promulgação da própria legislação federal.

Comentar-se-á também a Constituição do Estado de São Paulo por conter questões relevantes aos recursos hídricos e por incluir a criação do Sistema Integrado de Gerenciamento de Recursos Hídricos - SIGRH.

\subsubsection{Constituição do Estado de São Paulo}

A Constituição do Estado de São Paulo ${ }^{48}$ apresenta uma Seção ${ }^{49}$ destinada aos recursos hídricos, onde está prevista a instituição legal do SIGRH para, entre outras finalidades, a defesa contra eventos críticos que ofereçam riscos à saúde e à segurança públicas e prejuízos econômicos ou sociais; a celebração de convênios com os Municípios, para a gestão, por estes, das águas de interesse exclusivamente local, e a gestão descentralizada, participativa e integrada em relação às peculiaridades da respectiva bacia hidrográfica ${ }^{50}$.

Segundo MARIN et al (1999) "pertencem aos Estados-Membros todos os serviços públicos não reservados à União nem atribuídos aos Municípios, pelo critério do interesse local. Nesse sentido, cabem aos Estados os serviços e obras que ultrapassem as divisas de um Município ou que afetem interesses regionais”.

\footnotetext{
${ }^{48}$ Promulgada em 05 de outubro de 1989.

${ }^{49}$ Título VI, capítulo IV, Seção II.

${ }^{50}$ Artigo 205, parágrafos IV, V e VI.
} 
Para garantir os objetivos acima, a Constituição Estadual prevê a cobrança pelo uso dos recursos hídricos ${ }^{51}$, na forma da lei, e a aplicação do produto nos serviços e obras hidráulicas e de saneamento de interesse comum, previstos nos planos estaduais de recursos hídricos e de saneamento básico.

Prevê ainda que para proteger e conservar as águas e prevenir seus efeitos $\operatorname{adversos}^{52}$, o Estado incentivará a adoção pelos Municípios, de medidas para zoneamento de áreas inundáveis ou sujeitas a inundações freqüentes; para manutenção da capacidade de infiltração do solo; para implantação de sistema de alerta e defesa civil, visando garantir a segurança e a saúde públicas nos eventos hidrológicos indesejáveis e para instituição de programas permanentes de combate às inundações.

A Constituição Paulista, considerando também que a unidade de gestão e planejamento é a bacia hidrográfica, permite que seu território seja dividido, total ou parcialmente, em unidades regionais constituídas por agrupamento de municípios, mediante lei complementar, para integrar a organização, o planejamento e a execução de funções públicas de interesse comum. Para cada unidade regional está previsto um conselho de caráter normativo e deliberativo e, conforme o caso, a fusão de entidades ou órgãos públicos atuantes na região, assegurada a participação paritária do conjunto dos Municípios com relação ao Estado ${ }^{53}$.

Para assegurar a gestão por bacia hidrográfica, "o Estado apoiará a formação de consórcios entre os Municípios, objetivando a solução de problemas comuns relativos à proteção ambiental, em particular à preservação dos recursos hídricos e ao uso equilibrado dos recursos naturais" ${ }^{, 54}$.

A celebração dos convênios de cooperação, assim como dos consórcios públicos, apesar de úteis para determinadas estratégias e táticas do planejamento, são consideradas estruturas frágeis pois são instrumentos de caráter voluntário, podendo ser denunciado unilateralmente, prejudicando a otimização do sistema regional, uma vez que os órgãos de decisão autônoma dos municípios envolvidos podem destoar e tomar deliberações opostas, dependendo da situação política ou das pressões dos grupos de interesse atuantes nos Estados e Municípios (CBH-AT).

\footnotetext{
${ }^{51}$ Artigo 211.

${ }^{52}$ Artigo 210, incisos II, III e V.

${ }^{53}$ Artigos 153 e 154.
} 
Para que haja sincronia nas atuações estadual e municipais, os municípios devem compatibilizar, no que couber, seus planos, programas, orçamentos, investimentos e ações às metas, diretrizes e objetivos estabelecidos nos planos e programas estaduais, regionais e setoriais. Da mesma forma, o Estado deve compatibilizar os planos e programas estaduais, regionais e setoriais com os Planos Diretores dos Municípios e as prioridades das populações locais ${ }^{55}$.

Pela Constituição do Estado de São Paulo, os Planos Diretores são obrigatórios a todos os Municípios e devem abranger a totalidade do território municipal ${ }^{56}$. A importância dos Planos Diretores é reforçada por ser ele o balizador de leis municipais sobre zoneamento, loteamento, parcelamento, uso e ocupação do solo, índices urbanísticos e proteção ambiental ${ }^{57}$, aspectos fundamentais para o desenvolvimento da drenagem urbana.

Ao Estado cabe ainda, mediante lei complementar, incentivar a pesquisa, o desenvolvimento e a capacitação tecnológica para a resolução dos problemas ambientais e promover a informação sobres essas questões; promover a educação ambiental e a conscientização pública para a preservação, conservação e recuperação do meio ambiente, e controlar e fiscalizar obras, atividades, processos produtivos e empreendimentos que possam causar degradação ao meio ambiente, adotando medidas preventivas, corretivas ou sanções administrativas pertinentes.

\footnotetext{
${ }^{54}$ Artigo 201.

55 Artigo 155.

${ }^{56}$ Artigo 181, $1^{\circ}$.

${ }^{57}$ Artigo 181.
} 


\subsubsection{Política Estadual de Recursos Hídricos e Sistema Integrado de Gerenciamento de Recursos Hídricos do Estado de São Paulo}

A Política Estadual de Recursos Hídricos e Sistema Integrado de Gerenciamento de Recursos Hídricos - SIGRH do Estado de São Paulo, foram estabelecidos pela Lei Estadual n 7663 de 30 de dezembro de 1991, antecedendo a implantação das mesmas na esfera federal e redefinindo as prioridades de uso da água através da cobrança dos custos sociais e ambientais dos beneficiários desse recurso.

A Política Estadual de Recursos Hídricos paulista tem como princípios básicos, além daqueles estabelecidos pelas Constituições, o reconhecimento do valor econômico da água; o rateio do custo das obras entre os beneficiados e a compensação aos municípios afetados por restrições decorrentes de obras ou leis de proteção de recursos hídricos ${ }^{58}$.

O objetivo dessa política é "assegurar que a água, recurso natural essencial à vida, ao desenvolvimento econômico e ao bem-estar social, possa ser controlada e utilizada, em padrões de qualidade satisfatórios, por seus usuários atuais e pelas gerações futuras, em todo território estadual. Nesse sentido, impõe-se a exigência de utilização dos recursos hídricos do Estado de forma sustentável, dentro de padrões de aproveitamento racionais desses recursos" (CBH-AT, 2002).

Ao Estado mais uma vez é dada a função de fiscalizar, licenciar e incentivar a formulação de consórcios entre os municípios tendo em vista a realização de programas de desenvolvimento e proteção ambiental, de âmbito regional ${ }^{59}$ e a articulação com a União, outros Estados vizinhos e Municípios para atuação no controle dos recursos hídricos em seu território, levando em conta principalmente, o controle de cheias, a prevenção de inundações, a drenagem e a correta utilização das várzeas ${ }^{60}$.

Observa-se que a eficiência e eficácia dos objetivos e metas da Política Estadual de Recursos Hídricos e do SIGRH, só serão alcançadas se houver a devida

\footnotetext{
58 Artigo $3^{\circ}$.

${ }^{59}$ Artigo $5^{\circ}, \S 3^{\circ}$.

${ }^{60}$ Artigo $8^{\circ}$, inciso II.
} 
integração das diretrizes, planos, programas e projetos dos órgãos e entidades que as compõem, assim como dos órgãos municipais, e a cooperação da sociedade em geral.

Os instrumentos de que dispõe a Política Estadual de Recursos Hídricos são a outorga de direito de usos, a penalização das infrações, a cobrança pelo uso dos recursos hídricos, o rateio de custos das obras e o Plano Estadual de Recursos Hídricos - PERH.

O PERH, que orienta e direciona os demais instrumentos acima citados, deve ser instituído legalmente, com atualizações periódicas e prazo de vigência de quatro anos, tomando por base os Planos das Bacias Hidrográficas, as normas relativas à proteção do meio ambiente e às diretrizes de planejamento e gerenciamento ${ }^{61}$.

O Plano das Bacias Hidrográficas por sua vez, deve conter dentre outros, diretrizes gerais de caráter regional, capazes de orientar os Planos Diretores Municipais segundo as necessidades de recuperação, proteção e conservação dos recursos hídricos das regiões hidrográficas correspondentes.

Porém, o relacionamento entre os Comitês de Bacias, os Municípios e os demais órgãos e entidades setoriais estaduais e municipais tem um contingenciamento baseado em relações não claramente definidas, articuladas e integradas, prejudicando a implantação e os resultados esperados nos Planos das Bacias (CBH-AT, 2002a).

Por essa razão, é necessária a concepção de um modelo de relacionamento que mantenha a relativa autonomia administrativa dos diferentes setores, criando relacionamentos intergovernamentais entre entes político-administrativos de diferentes níveis (Estado e Municípios), que são dotados de autonomia política e dependentes da vontade de órgãos legislativos diversos (Assembléia Legislativa e Câmaras Municipais) (CBH-AT, 2002a).

Os instrumentos básicos de que se dispõe para essa finalidade são a penalização econômica das condutas não-conformes e a vinculação do acesso aos recursos financeiros à conformidade da conduta do agente público (CBH-AT, 2002a).

Entretanto, "essas alternativas levantam objeções relevantes quanto à seletividade desses mecanismos que podem possibilitar a penalização de governos

${ }^{61}$ Artigos 16 e 18. 
municipais por fenômenos que estariam fora de seu controle e representar um possível e indesejável mecanismo de exclusão", necessitando precaução quanto a forma como serão implementados e à adequada separação entre metas passíveis de adesão e aquelas sujeitas à observância de normas obrigatórias (CBH-AT, 2002a).

O SIGRH objetiva a execução da Política Estadual de Recursos Hídricos e a formulação, atualização e aplicação do PERH, congregando órgãos estaduais e municipais e a sociedade civil ${ }^{62}$, tendo nascido "de uma reação à fragmentação e à falta de coordenação que prevaleciam anteriormente na apropriação e uso "setorizado" dos recursos hídricos, tanto na esfera estadual como na federal" $(\mathrm{CBH}-$ AT, 2002)

O SIGRH tem como órgãos colegiados, consultivos e deliberativos, de nível estratégico, o Conselho Estadual de Recursos Hídricos - CRH (de nível central) e os Comitês de Bacias Hidrográficas (de nível regional) ${ }^{63}$.

Algumas das atribuições do CRH são discutir e aprovar propostas de projeto de lei referentes ao PERH, exercer funções normativas e deliberativas relativas à formulação, implantação e acompanhamento da Política Estadual de Recursos Hídricos e decidir os conflitos entre os Comitês de Bacias Hidrográficas ${ }^{64}$.

Tanto o CRH quanto os Comitês de Bacia Hidrográficas, contam com o apoio do Comitê Coordenador do Plano Estadual de Recursos Hídricos - CORHI cuja atribuição é a coordenação da elaboração do PERH.

Os Comitês de Bacias Hidrográficas podem instituir a Agência de Bacia, uma entidade jurídica, com estrutura administrativa e financeira própria ${ }^{65}$, que exercerá a função de secretaria executiva do respectivo Comitês de Bacias Hidrográficas. Entre as funções da Agência de Bacia estão a elaboração do Plano da Bacia Hidrográfica; o gerenciamento dos recursos financeiros da bacia e a promoção da articulação dos componentes do SIGRH, com outros sistemas do Estado, setores produtivos e a sociedade civil ${ }^{66}$.

$\mathrm{Na}$ Política Estadual de Recursos Hídricos e no SIGRH, cabe aos órgãos e entidades estaduais envolvidos, o apoio técnico, jurídico e administrativo, incluíndo a

\footnotetext{
62 Artigo 21.

${ }^{63}$ Artigo 22.

${ }^{64}$ Artigo 25.

65 Artigo 29.

${ }^{66}$ Artigo 29, $§ 1^{\circ}$.
} 
cessão de funcionários e instalações, o que também representa um entrave ao desenvolvimento dos recursos hídricos. Tal situação repete-se na esfera federal, exceção feita a ANA.

Considerando a importância dessas questões, o Comitê da Bacia Hidrográfica do Alto Tietê, incluiu entre os novos elementos de mudança a incorporar no Plano da Bacia Hidrográfica, o estudo da "solução institucional para o sistema de drenagem urbana, integrando as ações do Estado e dos Municípios, definindo a entidade estadual responsável e as formas alternativas de estruturas municipais, para aplicar, por exemplo o sistema de gestão do Plano de Macrodrenagem, o princípio impermeabilizador-pagador e a operação e manutenção do sistema de drenagem da bacia" (CBH-AT).

Dentro da visão da engenharia sanitária que parece caracterizar a legislação brasileira, as água de chuva são encaradas como esgotos e assim, seus lançamentos em corpos d'água podem ser objeto de cadastramento e outorga ${ }^{67}$, além de serem passíveis de cobrança, mas a canalização de córregos e a impermeabilização do solo extrapolam esses conceitos, enquadrando-se em obras que alteram o regime dos recursos hídricos, e assim dependem de manifestação, autorização ou licença dos órgãos competentes ${ }^{68}$. "Nada impede porém, que de acordo com o espírito da lei, sejam estabelecidos valores para a execução de obras ${ }^{69}$, com caráter regulador" (CBH-AT, 2002).

“A idéia do "impemeabilizador-pagador" também escapa à definição bastante específica que é dada na Lei $7663 / 91^{70}$, aos casos em que se pode cobrar pelo uso da água", entretanto o rateio de custos de obras de regularização entre os beneficiários, pode fundamentar essa cobrança, na medida em que se definam como beneficiários não somente o proprietário da várzea, como também o gerador dos excessos de vazão a montante ${ }^{71}$ (CBH-AT, 2002).

\footnotetext{
${ }^{67}$ Artigo 10.

68 Artigo 15, parágrafo I.

${ }^{69}$ Esse tipo de taxa tem caráter de custeio de despesas administrativas com a análise e aprovação do projeto e fiscalização da execução.

${ }^{70}$ Artigo 14.

${ }^{71}$ Artigo $3^{\circ}$, inciso IV.
} 


\subsubsection{Municipal}

"Do ponto de vista institucional, embora seja atribuição da União a prevenção de eventos críticos, a esfera pública responsável pela drenagem é o município" (PARKINSON et al, 2003).

"Medidas que afetam diretamente a gestão dos recursos hídricos podem ser implantadas no âmbito do sistema institucional das Bacias, mas aquelas que dizem respeito aos processos de fundo, de sustentabilidade de longo prazo garantida pelo controle das causas dos processos, dependem da articulação com uma gestão municipal pró-ativa." (CBH-AT, 2002)

Além do mais, o gerenciamento da drenagem urbana no Brasil é tradicionalmente efetuado pela estrutura técnica e administrativa vinculada diretamente ao poder municipal, sem um órgão gestor organizado como entidade independente, com autonomia financeira e gerencial $^{72}$.

Segundo o IBGE (2002), o serviço de drenagem urbana, em 99,8\% dos municípios, é prestado pelas próprias prefeituras municipais, normalmente através de órgãos ligados às secretarias municipais de obras e serviços públicos.

No uso dos instrumentos estabelecidos pelo Estatuto da Cidade por exemplo, o Município ganha poder central pois "compete aos poderes executivo e legislativo dos Municípios planejar o desenvolvimento urbano e ordenar a ocupação do território sob sua jurisdição, através de Planos Diretores, das Leis de Zoneamento, de Uso e Parcelamento do Solo, e dos Códigos de Obras, etc., no âmbito dos quais se inserem instrumentos de gestão como IPTU progressivo, parcelamento e edificação compulsória, desapropriação por utilidade pública ou interesse social, contribuição de melhoria, operações interligadas, transferência de potencial construtivo, etc." (CBH-AT, 2002).

O papel da prefeitura no gerenciamento dos recursos hídricos varia entre cogestora, orientadora e intermediadora. Como co-gestora, a prefeitura deveria assumir a liderança na mobilização dos agentes locais - comunidade e empreendedores

\footnotetext{
${ }^{72}$ Contrário a esta situação, o município de Santo André, integrante da região metropolitana de São Paulo, unificou os serviços de água, esgoto e drenagem, além de parte da defesa civil, criando uma autarquia para gerenciamento dos recursos hídricos, implementando uma taxa de manutenção dos serviços de drenagem de aproximadamente $\mathrm{R} \$ 2,99 /$ mês por residência e repassando também a taxa da coleta dos resíduos infectantes e da limpeza pública incluída no IPTU.
} 
privados - em defesa dos interesses do município. Como orientadora, em busca de uma mobilização efetiva, caberia à prefeitura informar e esclarecer sobre a importância do disciplinamento do uso e preservação da qualidade das águas, da manutenção das características naturais e das alternativas de controle existentes. Como integrante de um sistema de gestão dos recursos hídricos, impõe-se ao município articular-se com o governo central, União e Estado, exercendo o papel de interlocutor dos interesses locais (PARKINSON et al, 2003).

Apesar do Município não estar obrigado a participar ativamente no processo decisório regional e ao Estado não ser facultado impedir sua participação nas decisões sobre a organização, o planejamento e a execução de funções públicas de interesse comum, fica o Município obrigado a tolerar sua execução em seu território, pois o interesse regional compreende de certo modo o interesse local, e não cabe ao Município opor obstáculos a sua realização sob pena de prejudicar os outros municípios limítrofes (CBH-AT, 2002).

Nas questões da função pública de interesse comum, o território municipal, estadual e federal são figuras relativas dentro de um sistema federativo, sendo o território municipal, ao mesmo tempo território estadual e nacional. O território neste caso, é definido por um espaço identificado em razão de funções governamentais de diferentes níveis operacionais, sua natureza e características que o fazem ser de responsabilidade deste ou daquele ente público ou do conjunto deles, perfazendo uma questão de grande importância para a delimitação das competências privativas ou concorrentes dos Municípios e do Estado federado (CBH-AT, 2002)

“A existência de legislação é requisito básico à ação institucional do Município em matérias de interesse da sustentabilidade da bacia, porém não é condição suficiente". A efetiva aplicação dos dispositivos legais depende da existência de instrumentos de gestão municipal adequados, que permitam principalmente a fiscalização de seu cumprimento e garantam recursos humanos e financeiros necessários (CBH-AT, 2002).

Segundo PARKINSON et al (2003), a tendência atual é fortalecer nos planos municipais, a participação popular e a educação ambiental, respondendo a três desafios diferentes: a participação do cidadão, a cooperação social e a integração das políticas urbanas. 
A consolidação da participação dos agentes locais, no gerenciamento dos recursos hídricos, aumenta suas responsabilidades nesse processo, porém enfrentam os seguintes desafios (MEDEIROS, 1999):

- articulação entre as diversas esferas de governo, buscando a racionalização administrativa e evitando que o município seja apenas espectador de decisões tomadas em instâncias que não o consultam;

- Maior aproximação entre o município e outros órgãos gestores dos recursos hídricos para melhor informar a comunidade sobre a importância da preservação e controle do uso desses recursos;

- Maior empenho das esferas superiores na informação e formação dos prefeitos e comunidades;

- Incentivo à pesquisa sobre o tema da participação social na área de gestão dos recursos hídricos, buscando identificar formas de institucionalização da participação e representação dos organismos locais.

Assim cabe ao Município, exercer seu papel primordial no desenvolvimento e alcance das metas estabelecidas, principalmente no que tange ao ordenamento territorial; ser o interlocutor entre governos e munícipes, tanto nas discussões das questões relativas aos recursos hídricos, como na defesa dos interesses locais ou no estabelecimento de acordos possíveis com os demais órgãos das diversas esferas; e fomentar a participação e o entendimento sobre essas questões. 


\section{ESTRUTURAS ALTERNATIVAS OU COMPENSATÓRIAS}

Os princípios da drenagem urbana contemporânea solicitam a utilização de estruturas alternativas ou compensatórias para equilibrar os efeitos da urbanização sobre o ciclo hidrológico, procurando manter as vazões pré-existentes e interceptando-as antes de atingir as redes de drenagem, sendo muitas vezes impostas pelas próprias limitações das soluções convencionais.

As motivações para utilização dessas estruturas são a possibilidade de minimizar interferências nas condições naturais de escoamento, a vantagem econômica sobre os dispositivos clássicos, a utilização para fins recreacionais, a facilidade de incorporação paisagística, a melhoria na qualidade da água, entre outras (McCUEN, WALESH e RAWIS, 1983).

Diversas estruturas alternativas, como trincheiras de infiltração, pavimentos porosos, reservatórios de armazenamento, etc. têm sido e continuam a ser estudadas e todas elas, baseiam-se na maior utilização de superfícies permeáveis e áreas de infiltração e/ou armazenamento (TUCCI e MARQUES, 2001).

NASCIMENTO, ELLIS e DEUTSCH (1999) apontam um crescente interesse, especialmente nos grandes centros urbanos brasileiros, por modificações profundas na forma de planejamento e concepções dos sistemas tradicionais de drenagem, onde as estruturas alternativas terão inevitavelmente, um papel importante nas novas estratégias de gerenciamento das águas pluviais.

Diversos autores atestam o potencial de uso dessas estruturas para solução dos problemas de drenagem urbana e informam a existência de intensas pesquisas na área, porém todos apontam a necessidade de estudos mais aprofundados e detalhados, apresentando as motivações abaixo (CRUZ, ARAÚJO e SOUZA, 1999); (TUCCI e MARQUES, 2001); (PARKINSON, 2003) e (GRACIOSA, 2004):

- Utilização muito recente, principalmente no Brasil;

- Dificuldade de obtenção de parâmetros de projeto e dimensionamento;

- Necessidade de aprimoramentos construtivos; 
- Falta de comprovação da eficácia das soluções alternativas perante diferentes cenários;

- Escassez de informações sobre a vida útil dos sistemas;

- Falta de avaliação da atuação conjunta na macrodrenagem;

- Dificuldades de implementação;

- Falta de experiências práticas;

- Falta de normatização;

- Interesse crescente também por parte dos países em desenvolvimento.

FRENDRICH (2003a) recomenda que sejam dirigidos esforços e recursos para o desenvolvimento de estudos hidrológicos referentes ao trinômio armazenamento, utilização e infiltração - das águas pluviais, como forma de minimização da extensão das áreas inundáveis em bacias hidrográficas intensamente urbanizadas e também para reaproveitamento.

Poucos trabalhos avaliam a eficiência e o desempenho das estruturas alternativas através de casos reais, principalmente no Brasil, fazendo da experiência internacional fonte valiosa de recursos, porém não substituem a necessidade da constatação das possibilidades de usos frente à diversidade regional brasileira e suas particularidades.

\subsection{Conceitos Básicos}

Primariamente, o que distingue as soluções estruturais alternativas ou compensatórias são os conceitos envolvidos, normalmente armazenamento ou infiltração, e no caso de dispositivos que combinam esses dois conceitos, a finalidade principal.

Esses dois conceitos básicos podem ser definidos da seguinte forma:

- Armazenamento: promovem a redução do pico das enchentes, através do amortecimento das ondas de cheias pela retenção temporária dos volumes escoados em dispositivos que propiciam acúmulo de água, sem entretanto na 
maioria dos casos, reduzir o volume do escoamento superficial. Rotineiramente são constituídos por reservatórios que podem ser criados nos mais diversos lugares, com tamanhos e formatos diferentes e constituídos dos mais variados materiais;

- Infiltração: promovem a redução dos volumes escoados utilizando dispositivos que criam e facilitam a disposição das águas pluviais no solo, através da utilização de fluxos subterrâneos que ao mesmo tempo armazenam e retardam o escoamento superficial e incrementam a recarga dos lençóis freáticos, podendo, dependendo das condições locais e da intensidade das chuvas, eliminar totalmente o escoamento superficial. Esses dispositivos conseguem ser promulgados em qualquer lugar que possibilite o contato da água com o solo, podendo até mesmo ser constituído pela manutenção da própria permeabilidade da camada superficial do solo.

FENDRICH (2003) comenta que os conceitos de armazenamento, infiltração e utilização das águas pluviais em ambientes urbanos, voltam a ser incorporados pelas comunidades técnicas nacionais e internacionais envolvidas no assunto, de forma crescente a cada dia, demonstrando a importância desses conceitos para o incremento do bem estar e da qualidade de vida das populações citadinas.

Com relação ao armazenamento, existem três tipos básicos de estruturas:

- Retenção: quando o escoamento é armazenado por longos períodos e não descarregado a jusante durante o evento que o gerou, permanecendo com uma lâmina de água que pode ser utilizada para fins diversos de abastecimento não potável, infiltração local ou melhoramento paisagístico;

- Detenção: quando o armazenamento é de curto prazo, normalmente inferior a 24 horas, suficiente apenas para controlar o efeito das cheias a jusante, com vazão de saída inferior ao de entrada e volume efluente igual ao afluente, podendo fora dos evento de cheias, ser utilizado para fins recreacionais;

- Condução: quando o armazenamento é feito de forma transitória, no próprio sistema de drenagem, com utilização de velocidades baixas de escoamento e seções mais amplas. 
GRACIOSA (2004) e MAKROPOULOS, BUTLER e MAKSIMOVIC (1999) apresentam os principais parâmetros e variáveis envolvidos no tratamento e escolha de qualquer estrutura de infiltração, observando que os dois últimos termos são responsáveis pelo processo de colmatação, um dos maiores problemas enfrentados por este tipo de dispositivo:

- Propriedades físicas e hidráulicas do solo, principalmente a taxa de infiltração;

- Nível e suscetibilidade do lençol freático;

- Densidade da vegetação do entorno;

- Volume de armazenamento das estruturas;

- Qualidade das águas a serem infiltradas;

- Granulometria da camada superficial do solo;

- Teor de sólidos suspensos na água.

URBONAS e STAHRE (1993) comentam que infelizmente, não existe uma nomenclatura padrão para designar os vários tipos de estruturas de controle alternativos no campo da engenharia e que cada autor deve esclarecer sua própria terminologia, posto que quando um dispositivo de controle alternativo utiliza os dois conceitos principais expostos acima, pode ser tanto classificado como uma estrutura de armazenamento ou como de infiltração, dependendo do autor.

\subsection{Tipologias Principais}

Alguns dos principais e mais estudados tipo de estruturas de armazenamento e infiltração encontrados na literatura para controle do escoamento superficial são apresentados a seguir. 


\subsubsection{Reservatórios de armazenamento e controle de cheias}

Uma das primeiras soluções alternativas colocadas em prática foram os reservatórios de armazenamento e controle de cheias, cuja finalidade é permitir a distribuição temporal dos volumes excedentes e atenuar os picos de vazão para um limite previamente estabelecido (NASCIMENTO, ELLIS e DEUTSCH, 1999).

Existem duas tipologias principais de reservatórios: reservatório de detenção e reservatório de retenção. Os demais são sempre derivações destas duas tipologias.

O reservatório de detenção, também conhecido como bacia de detenção, detention basin, detention pond ou dry pond, fornece um armazenamento temporário com descarga gradual a jusante, sendo projetado para permanecer seco entre eventos chuvosos, podendo nessas ocasiões ser utilizado para outras finalidades, como por exemplo recreação.

URBONAS (1999) comenta que dentre todos as estruturas alternativas ou compensatórias é a mais promissora e melhor entendida. Para TUCCI, PORTO e BARROS (1995), é o dispositivo mais utilizados nos Estados Unidos, Canadá e Austrália. Sendo os reservatórios de detenção objeto de estudo deste trabalho, será melhor detalhado no próximo capítulo

O reservatório de retenção, retention basin, retention pond ou wet pond, é projetado para manter uma lâmina de água permanente na parte inferior e promover a infiltração, sendo indicado também para controle da qualidade da água pois implicam num longo tempo de permanência.

Apesar de exigir grandes áreas e cuidados maiores do que aqueles necessários para os reservatórios de detenção, sua implantação é propícia quando o lençol freático é alto e deseja-se criar um lago com fins paisagísticos e de recreação, facilitando assim sua aceitação pela população.

Em Santo André, em São Paulo, a SEMASA criou e opera um desses reservatórios que serve como sistema de lazer para os moradores locais, como pode ser notado na figura 14. 


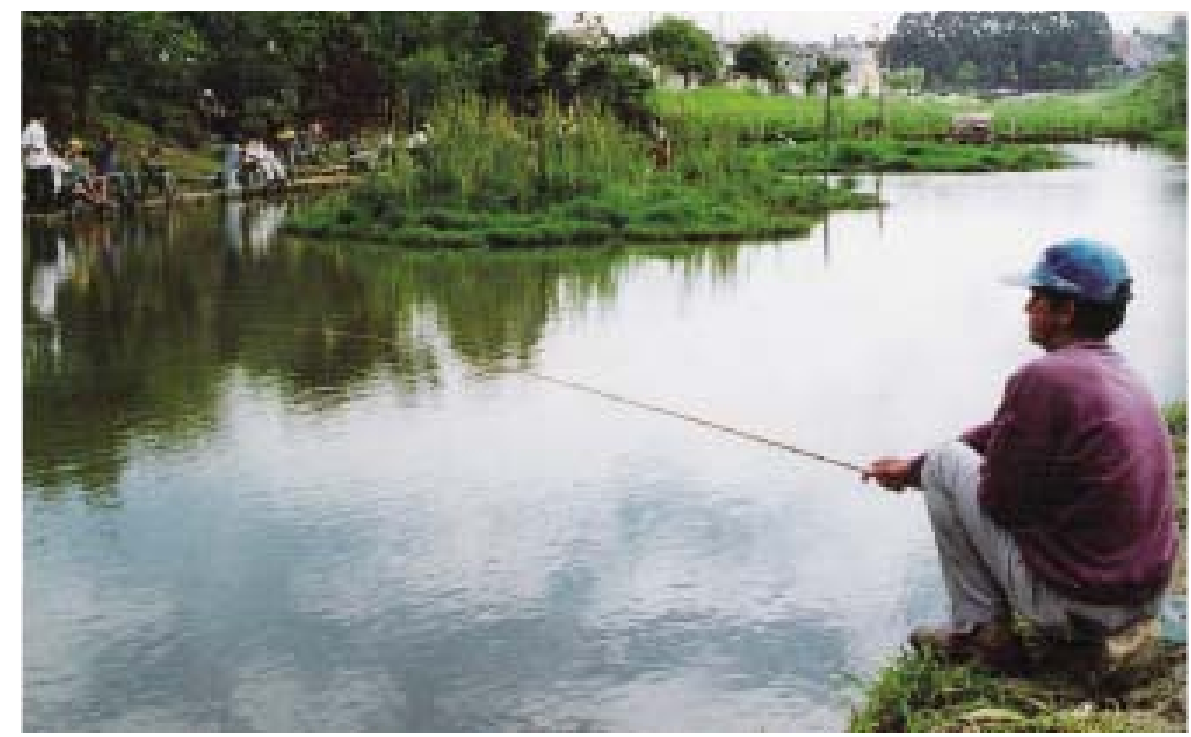

Figura 14 - Reservatório de retenção, Santa Terezinha, 2002 Fonte : SEMASA - ABC Imagem apud Santos (2002)

Nos Estados Unidos, onde a melhoria da qualidade da água é a finalidade principal das estruturas de armazenamento, estudou-se o aperfeiçoamento dos reservatórios de detenção para alcançar estes objetivos através da incorporação de dispositivos que evitem a ressuspensão dos sólidos e aumentem o tempo de detenção (e.g. 48 horas), sendo essas estruturas conhecidas como extended detention basin e visualizadas nas figuras 15,16 e 17.

No Brasil não há citações a respeito desse tipo de reservatório, porém seus princípios podem estar sendo utilizados para controle de sedimentos, englobados no termo genérico de reservatório de detenção. 


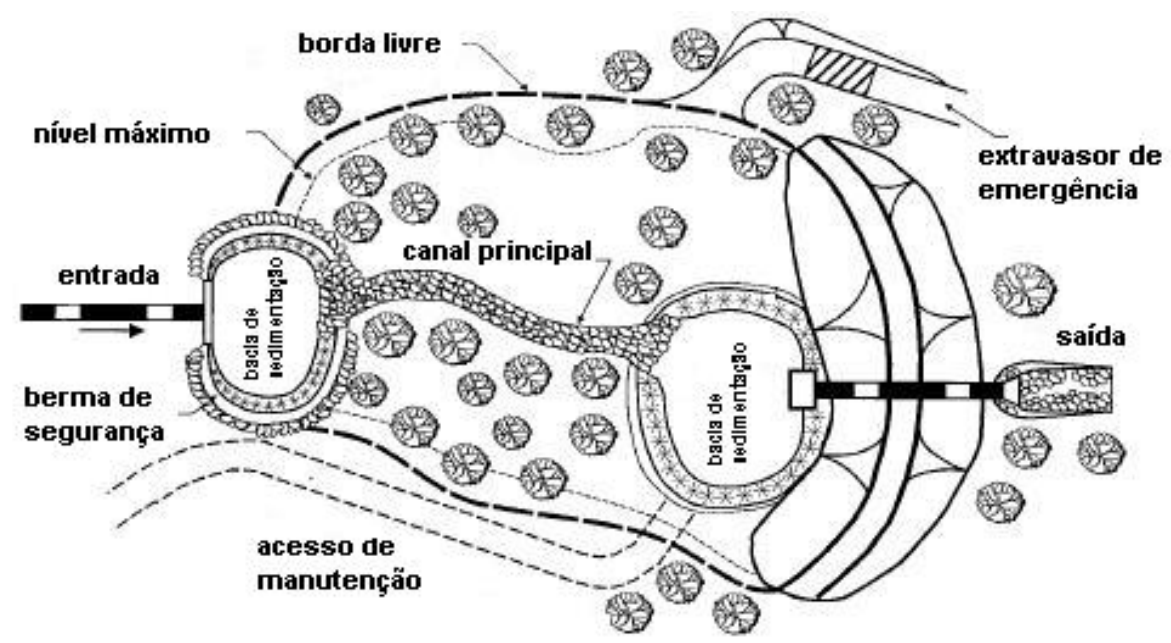

Figura 15 - Extended detention basin (planta)

Fonte : CASQA (2003)

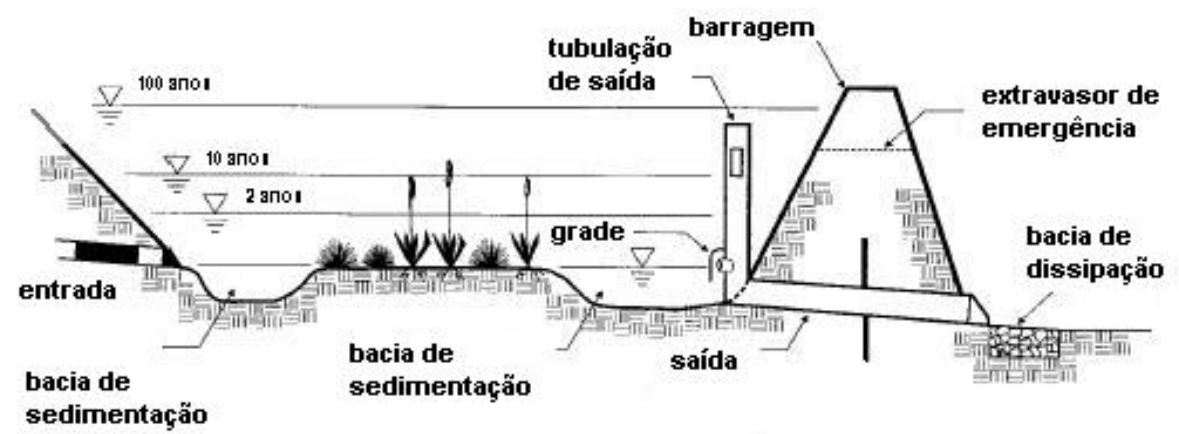

Figura 16 - Extended detention basin (perfil)

Fonte : CASQA (2003) 

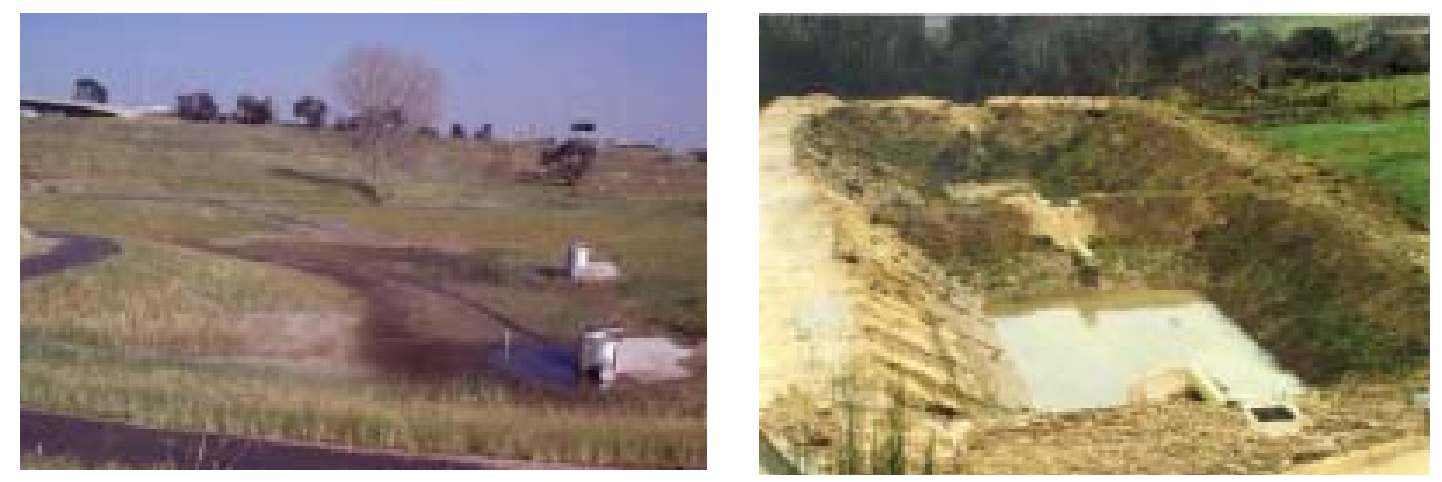

Figura 17 - Extended detention basin

Fonte : CASQA (2003) e Vieira e Oliveira (2001)

Alagadiços ou wetland são reservatórios de retenção de pouca profundidade que fazem uso da vegetação para aumentar a eficiência na remoção de poluentes e sedimentos e facilitar processos de infiltração, mantendo sempre uma lâmina de água em seu interior de aproximadamente $15 \mathrm{~cm}$ (TUCCI, 1995).

PERSON, SOMES e WONG (1999), estudando a eficiência dos reservatórios de retenção e dos alagadiços afirmam que ambos são largamente utilizados para desempenhar inúmeras funções, inclusive para controle do escoamento superficial, e que muitos dos problemas encontrados poderiam ser minimizados ou evitados através da utilização de melhores princípios de projetos, observando por exemplo, que uma eficiência hidráulica maior poderia ser alcançada com definições apropriadas de localização, de forma e profundidade e das estruturas de entrada e saída.

PIEL, PEREZ e MAYTRAUD (1999) consideram que em áreas densamente urbanizadas os armazenamentos temporários oferecem vantagens consideráveis em termos de paisagismo, custo, segurança e durabilidade das estruturas. Os autores defendem o uso de reservatórios abertos com usos múltiplos apesar de demandarem investimentos maiores em pesquisa e maior cuidado durante a fase de construção, porque após concluídos, não requerem manutenção ou equipamentos específicos e quando comparados com outras técnicas de armazenamento, tendem a reduzir custos a longo prazo, podendo ser facilmente mantidos pelas gerações futuras, além de serem elementos essenciais para a segurança das áreas sujeitas às inundações. 


\subsubsection{Pavimentos permeáveis}

Pavimento permeável é definido como um dispositivo de infiltração onde o escoamento superficial é desviado através de uma superfície permeável para dentro de um reservatório de pedras localizado sob a superfície do terreno (URBONAS e STAHRE, 1993) e (TUCCI e MARQUES, 2000), podendo ser dos seguintes tipos:

- Pavimento de asfalto poroso (i): similar ao pavimento asfáltico convencional com a diferença de que é retirada a fração de areia fina da mistura de agregados;

- Pavimento de concreto poroso (ii): construídos da mesma forma do pavimento de concreto tradicional e assim como no pavimento de asfalto poroso, não possui a fração de areia fina da mistura de agregados

- Pavimento de bloco de concreto vazado (iii): módulos de blocos de concreto vazado e preenchidos com material granular como a areia, ou vegetação rasteira como a grama.

Segundo SHULLER (1987) citado por TUCCI e MARQUES (2000), normalmente os pavimentos permeáveis são compostos pela capa ou revestimento poroso, uma camada de agregado fino ou médio (filtro) e uma camada de agregado graúdo cujas dimensões determinam a capacidade de armazenamento do pavimento, podendo a água armazenada ser infiltrada ou coletada por tubos de drenagem. Filtros geotêxteis podem ser colocados sob a camada de agregado fino ou médio e no contato com o solo para evitar a migração de partículas finas (figura 18).

ARAÚJO, GOLDENFUM e TUCCI (1999) observam que a capa de revestimento age somente como um condutor rápido para o escoamento superficial alcançar o reservatório de agregados graúdos. 


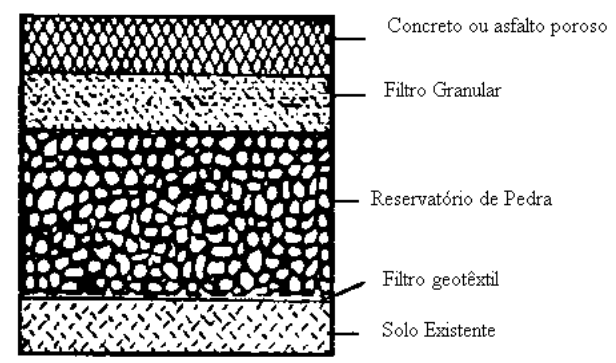

(i) e (ii) Concreto ou Asfalto Poroso

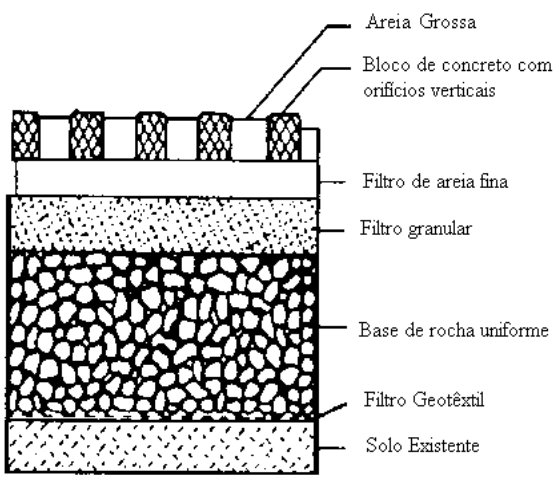

(iii) Blocos de Concreto Vazados

Figura 18 - Tipos de pavimentos permeáveis

Fonte : Tucci e Marques (2000)

O uso dos pavimentos permeáveis é restrito a áreas de estacionamentos e passeios públicos devido à sua baixa capacidade de suporte, sendo recomendado para tráfego de veículos leves (TUCCI e MARQUES, 2000). Contudo TUCCI (1995), considera que dependendo do tipo de pavimento permeável, estes podem ser utilizados até em ruas de zonas residenciais de pouco tráfego.

SPIRN (1995) comenta que os estacionamentos respondem pela maioria dos espaços abertos e pavimentados nas cidades, podendo servir para reter ou absorver as águas pluviais, e acrescenta que calçamentos de blocos de concreto em treliças, com grama plantada nos interstícios, são largamente utilizados em cidades européias e têm sido empregados também em algumas partes das cidades americanas.

Outras restrições aos pavimentos porosos provêm da declividade do terreno que deve ser baixa, da capacidade de infiltração do solo que deve ser superior a 7 $\mathrm{mm} / \mathrm{h}$, do lençol freático que deve estar relativamente profundo e da qualidade do escoamento superficial para que não haja contaminação do mesmo.

URBONAS e STAHRE (1993) ressaltam que mesmo quando não há condições de infiltração ou existem possibilidades de contaminação do lençol freático, os pavimentos permeáveis podem ser utilizados como um "poço de detenção" e MIKKELSEN et al. (1996) citado por GRACIOSA (2004) acrescenta que a baixa permeabilidade do solo não representa restrição técnica à implantação de estruturas de infiltração, mas sim restrição econômica. 
Segundo ARAÚJO, GOLDENFUM e TUCCI (1999), as principais vantagens dos pavimentos permeáveis são a redução ou eliminação das redes de drenagem, preservação do equilíbrio natural das condições hídricas locais, controle das descargas de pico e do volume do escoamento superficial, remoção de poluentes e criação de superfícies mais seguras para dirigir (figura 19). Como desvantagens, os autores citam o alto risco de entupimento, a necessidade de inspeções regulares e um possível risco de contaminação das águas subterrâneas.

CRUZ, ARAÚJO e SOUZA (1999) acrescentam às desvantagens desse tipo de pavimento, os problemas decorrentes da falta de controle na construção e manutenção, que podem comprometer o desempenho dos mesmos.

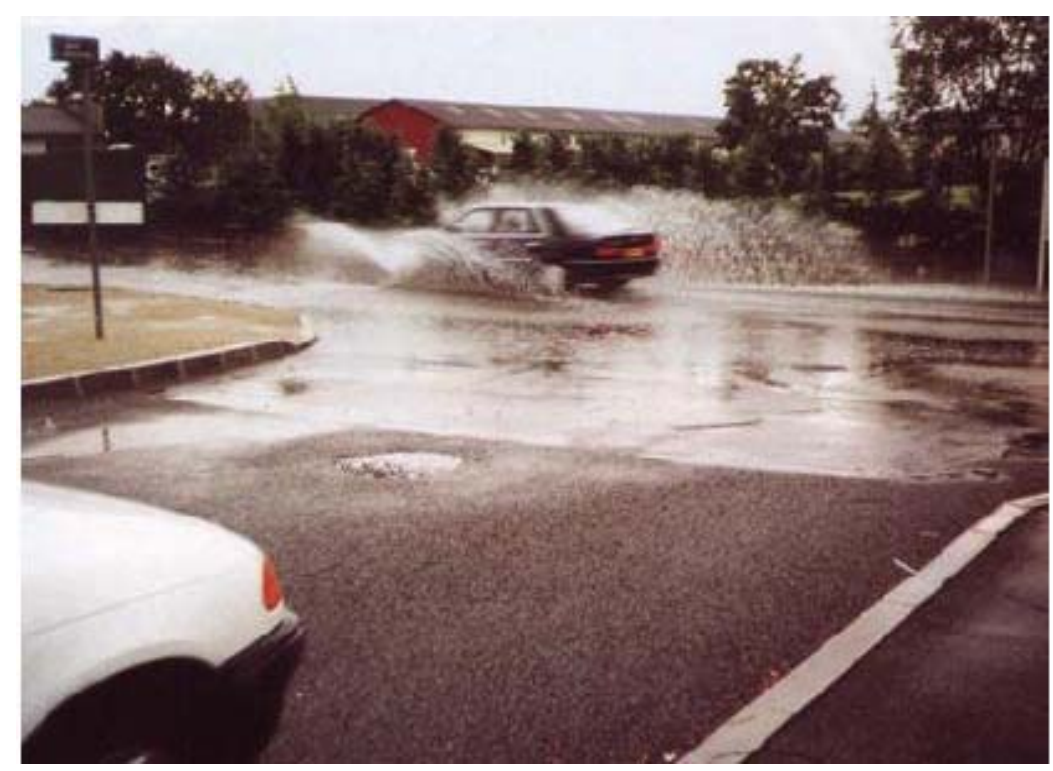

Figura 19 - Diferença entre pavimento convencional e pavimento poroso Fonte : Azzot et al (1994) apud Vieira e Oliveira (2001)

LAWRENCE et al.(1996), apud GRACIOSA (2004), comenta que, para preservar o bom funcionamento dos pavimentos porosos, deve ser feita uma manutenção regular com equipamentos especiais, que aplicam ao pavimento altas pressões de "sopro" ou sucção.

TUCCI e MARQUES (2000) concordam com as vantagens da utilização dos pisos permeáveis desde que utilizados racionalmente, respeitando os limites físicos de aplicação e de manutenção preventiva trimestral para evitar a colmatação. 
URBONAS (1999) entretanto, observa que evidências de campo indicam que os blocos de concreto vazados são os únicos que têm se mostrado eficientes a longo prazo e desde que foi iniciada sua utilização em meados de 1970, existem poucos registros de problemas. Por outro lado, SCHUELER et. al. (1991) apud URBONAS (1999) observa que pavimentos porosos monolíticos tendem a colmatar um ou dois anos após sua instalação.

ARAÚJO, GOLDENFUM e TUCCI (1999) avaliaram experimentalmente a eficiência do pavimento de blocos de concreto com elementos vazados (Garden Blocks) na redução do escoamento superficial em comparação ao solo compactado ${ }^{73}$, obtendo os resultados apresentados na figura 20 e tabela $6^{74}$.

Eles concluíram, dos resultados apresentados, que o pavimento de blocos de concreto com elementos vazados não apenas manteve as condições originais como reduziu os escoamentos superficiais a valores próximos a zero ${ }^{75}$, mostrando-se como dispositivos altamente recomendados para controle dos volumes escoados.

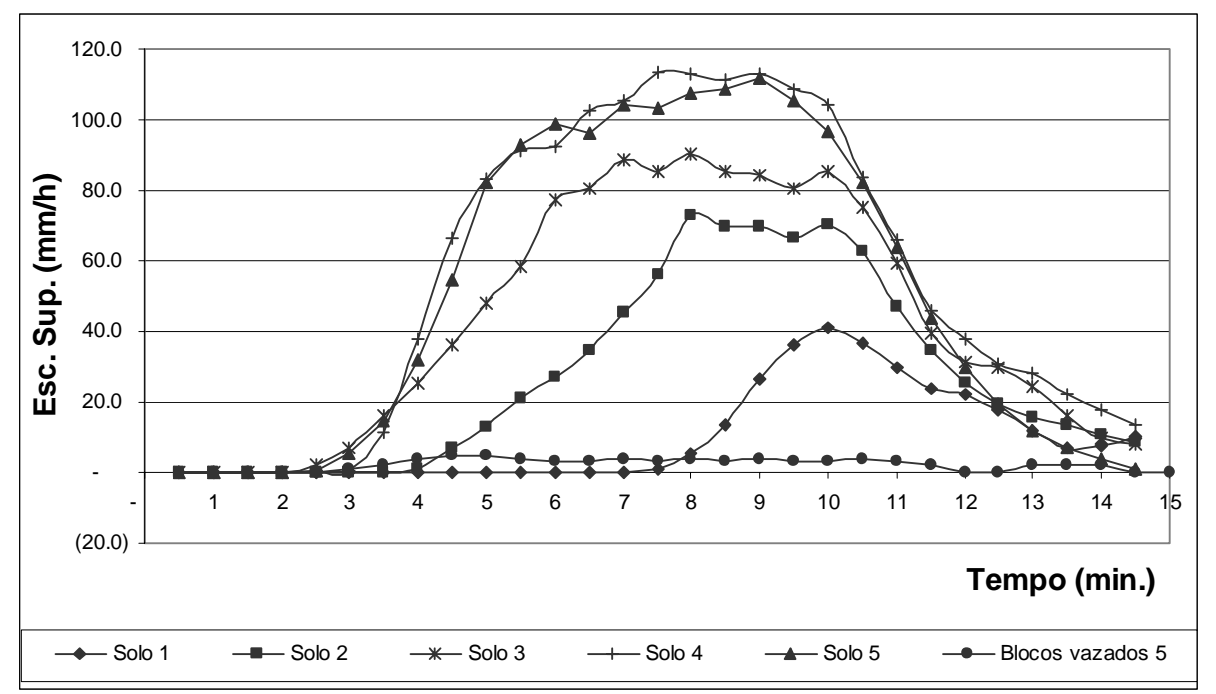

Figura 20 - Resultado dos escoamentos no solo compactado e nos blocos vazados Fonte : Araújo, Goldenfum e Tucci (1999)

\footnotetext{
${ }^{73}$ Utilizando simulador de chuva com capacidade de gerar precipitações de intensidades variáveis sobre módulos de $1 \mathrm{~m}^{2}$ de cada tipo de pavimento analisado e chuva de projeto de 10 minutos de duração, com período de retorno máximo de 5 anos.

${ }^{74}$ Os termos solo 1, solo 2, etc. representam diferentes simulações de intensidade de chuvas sobre o solo compactado.
} 
Tabela 6 - Simulações de chuva no solo compactado e nos blocos vazados

\begin{tabular}{|c|c|c|c|c|c|c|}
\hline Características & $\begin{array}{c}\text { Solo } \\
\text { Ensaio } 1\end{array}$ & $\begin{array}{c}\text { Solo } \\
\text { Ensaio } 2\end{array}$ & $\begin{array}{c}\text { Solo } \\
\text { Ensaio } 3\end{array}$ & $\begin{array}{c}\text { Solo } \\
\text { Ensaio } 4\end{array}$ & $\begin{array}{c}\text { Solo } \\
\text { Ensaio } 5\end{array}$ & $\begin{array}{c}\text { Blocos } \\
\text { Vazados }\end{array}$ \\
\hline $\begin{array}{l}\text { Intensidade simulada } \\
(\mathrm{mm} / \mathrm{h})\end{array}$ & 46 & 68 & 84 & 102 & 112 & 110 \\
\hline Chuva total (mm) & 7,66 & 11,33 & 14,00 & 17,00 & 18,66 & 18,33 \\
\hline Escoamento total (mm) & 2,52 & 6,67 & 10,43 & 13,45 & 12,32 & 0,5 \\
\hline $\begin{array}{ll}\text { Coeficiente } & \text { de } \\
\text { escoamento }^{76} & \end{array}$ & 0,33 & 0,59 & 0,74 & 0,79 & 0,66 & $0,03^{77}$ \\
\hline $\begin{array}{l}\text { Umid. Inicial Solo } \\
\left(\mathrm{cm}^{3} / \mathrm{cm}^{3}\right)\end{array}$ & 32,77 & 32,80 & 32,81 & 32,70 & 32,81 & 32,24 \\
\hline $\begin{array}{l}\text { Umid. Final Solo } \\
\left(\mathrm{cm}^{3} / \mathrm{cm}^{3}\right)\end{array}$ & 32,79 & 32,79 & 32,87 & 32,74 & 32,84 & 32,26 \\
\hline
\end{tabular}

(Fonte: Araújo, Goldenfum e Tucci, 1999)

Outro trabalho experimental dos mesmos autores, publicado por TUCCI e MARQUES (2000), dá continuidade às avaliações experimentais com pavimentos permeáveis, mantendo as mesmas características das simulações anteriores e acrescentado outros tipos de pavimentos: pavimento de paralelepípedos, pavimento de blocos de concreto e pavimento de concreto. Todas as 5 superfícies estudadas podem ser visualizadas na figura 21 .

\footnotetext{
${ }^{75}$ Ver nota 76 e 77.

${ }^{76}$ Observa-se que o coeficiente de escoamento superficial varia conforme a intensidade e a duração das chuvas, demonstrando os processos que ocorrem no solo durante as precipitações, não sendo um parâmetro estático.

${ }^{77} \mathrm{O}$ coeficiente de escoamento superficial de 0,03 apresentado para o bloco de concreto vazado neste estudo, representa a condição ideal de utilização, uma vez que a chuva simulada $(110 \mathrm{~mm} / \mathrm{h})$ é a mesma utilizada para determinação das dimensões da camada de agregado graúdo, responsável pela capacidade de armazenamento dos pavimentos permeáveis. Para valores maiores do que a chuva de projeto, o coeficiente de escoamento superficial será proporcionalmente maior.
} 


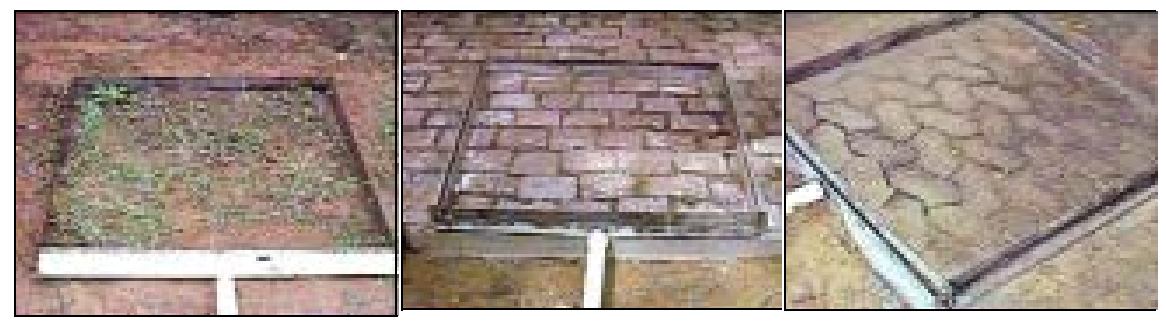

Solo Compactado Pavimento de Pavimento de Blocos

Paralelepípedos de Concreto

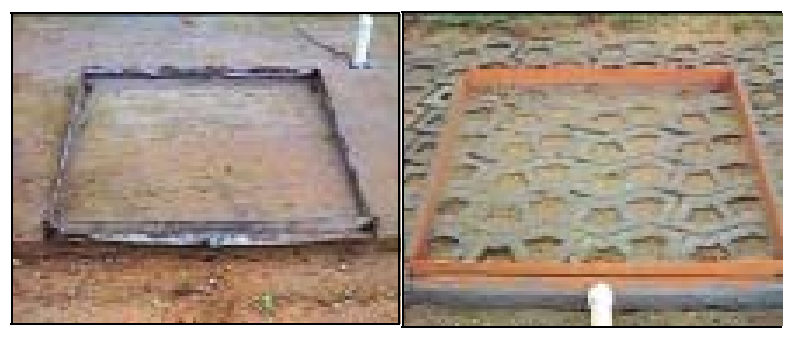

Pavimento de Pavimento de Blocos

Concreto Vazados

Figura 21 - Tipos de pavimentos avaliados

Fonte : Tucci e Marques (2000)

Os resultados obtidos são apresentados na tabela 7 e na figura 22 , onde observa-se que no pavimento impermeável praticamente toda a chuva gerou escoamento superficial, com acréscimo de $44 \%$ em relação ao solo compactado; para as superfícies semi-permeáveis o acréscimo foi de $22 \%$ para o bloco de concreto e de $11 \%$ para o paralelepípedo; o piso permeável de blocos de concreto vazado praticamente não produziu escoamento ${ }^{78}$ sendo seus valores inferiores ao do solo compactado.

Desta forma, o uso dos pavimentos permeáveis ou semi-permeáveis continua sendo aconselhado em substituição aos pisos impermeáveis, embora possa acarretar aumento de escoamento superficial em relação a áreas em estado natural.

${ }^{78}$ Ver nota 77. 
Tabela 7 - Resultado das simulações de chuva em diferentes tipos de pavimentos

\begin{tabular}{|l|c|c|c|c|c|}
\hline Características & $\begin{array}{l}\text { Solo } \\
\text { compactado }\end{array}$ & $\begin{array}{l}\text { Pavimento } \\
\text { concreto }\end{array}$ & $\begin{array}{l}\text { Blocos de } \\
\text { concreto }\end{array}$ & $\begin{array}{l}\text { Parale- } \\
\text { pípedo }\end{array}$ & $\begin{array}{l}\text { Blocos } \\
\text { Vazados }\end{array}$ \\
\hline Tipo de pavimento & Perm. & Imperm. & $\begin{array}{c}\text { Semi- } \\
\text { perm. }\end{array}$ & $\begin{array}{c}\text { Semi- } \\
\text { perm. }\end{array}$ & Perm. \\
\hline $\begin{array}{l}\text { Intensidade simulada } \\
(\mathrm{mm} / \mathrm{h})\end{array}$ & 46 & 68 & 84 & 102 & 110 \\
\hline Chuva total (mm) & 7,66 & 11,33 & 14,00 & 17,00 & 18,33 \\
\hline $\begin{array}{l}\text { Escoamento total } \\
(\mathrm{mm})\end{array}$ & 2,52 & 6,67 & 10,43 & 13,45 & 0,5 \\
\hline Coef. escoamento & 0,33 & 0,59 & 0,74 & 0,79 & $0,03{ }^{80}$ \\
\hline $\begin{array}{l}\text { Umid. Inicial Solo } \\
\left(\mathrm{cm}^{3} / \mathrm{cm}^{3}\right)\end{array}$ & 32,77 & 32,80 & 32,81 & 32,70 & 32,24 \\
\hline $\begin{array}{l}\text { Umid. Final Solo } \\
\left(\mathrm{cm}^{3} / \mathrm{cm}^{3}\right)\end{array}$ & 32,79 & 32,79 & 32,87 & 32,74 & 32,26 \\
\hline
\end{tabular}

(Fonte: Araújo, Goldenfum e Tucci, 2000)

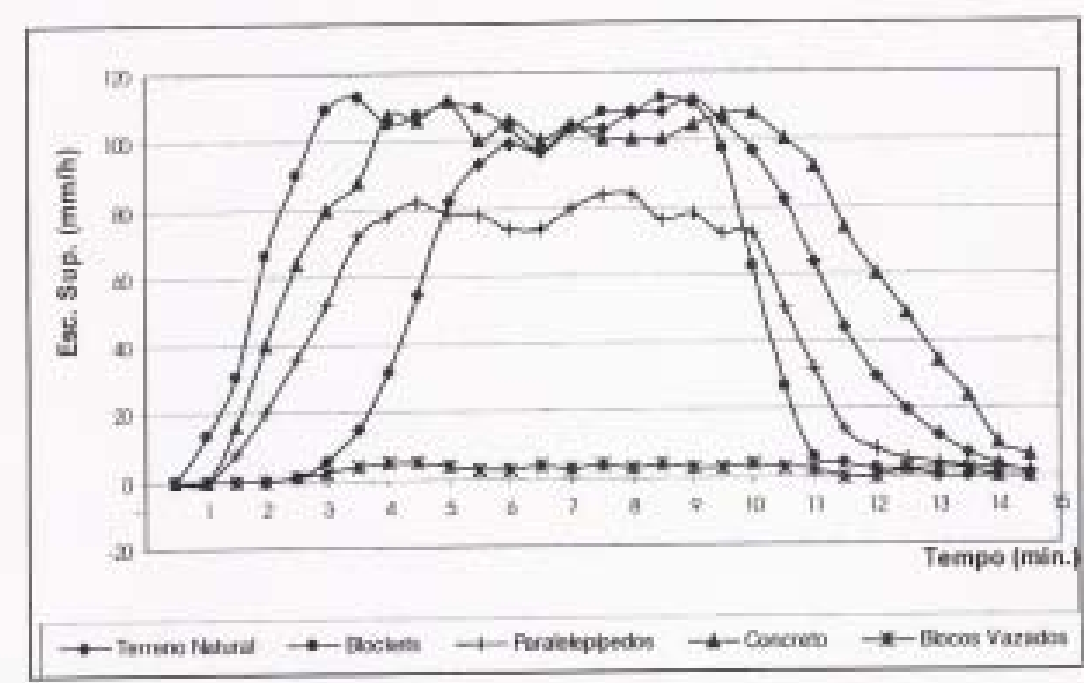

Figura 22 - Escoamento superficial observado por tipo de pavimento Fonte : Araújo, Goldenfum e Tucci (2000)

\footnotetext{
${ }^{79}$ Ver nota 76

${ }^{80}$ Ver nota 77.
} 
Com relação a custos, estudo sobre estruturas de controle do escoamento urbano elaborado por CRUZ, ARAÚJO e SOUZA (1999), levantou os seguintes valores para os pavimentos permeáveis ${ }^{81}$ (tabela 8 ):

Tabela 8 - Preço de implantação dos pavimentos

\begin{tabular}{|l|c|}
\hline Tipo de Pavimento & Custos unitários $\left(\mathbf{R} \$ \mathbf{m}^{\mathbf{2}}\right)$ \\
\hline Blocos de concreto pré-moldados & 10,10 \\
\hline Paralelepípedos & 16,74 \\
\hline Concreto impermeável & 13,14 \\
\hline Blocos de concreto pré-moldados & 18,22 \\
vazados & \\
\hline Concreto poroso & 19,06 \\
\hline
\end{tabular}

(Fonte : Cruz, Araújo e Souza, 1999)

Os autores observam que nos custos apresentados não foram consideradas despesas de manutenção, que consiste na limpeza dos poros dos pavimentos porosos (concreto poroso) com jatos d'água e máquinas de aspiração de sedimentos e poeiras, pela inexistência de empresas especializadas na manutenção deste tipo de revestimento no país, porém fornecem um custo médio de gastos em manutenção nos Estados Unidos, que é da ordem de 1 a $2 \%$ do custo de implantação dos pavimentos.

Assim, de forma geral, os pavimentos permeáveis são ainda mais caros que o concreto impermeável que serve de base para comparação neste estudo, porém o incremento de uso dos primeiros pode levar a uma redução de custos tanto de implantação como de manutenção nos próximos anos.

${ }^{81}$ com base em preços praticados em Porto Alegre 


\subsubsection{Trincheiras de Infilttração}

Trincheiras de infiltração (figura 23) são dispositivos de drenagem urbana para controle do escoamento superficial na fonte, com princípio de funcionamento baseado no armazenamento temporário da água para infiltração no solo. São constituídas por frestas abertas no solo e preenchidas por material granular (brita, pedra de mão, etc.), com porosidade em torno de $40 \%$, envoltas por mantas geotêxteis, que além da função estrutural, impedem a entrada de finos e reduzem os riscos de colmatação precoce (CRUZ, ARAÚJO e SOUZA, 1999) e (SOUZA e GOLDENFUM, 1999).

As trincheiras de infiltração podem ser utilizadas como elemento isolado em lotes residenciais ou como parte de um sistema que integre toda a bacia (GRACIOSA, 2004). Normalmente são utilizadas para pequenas áreas, com menos de 2 ha, em conjunto com outros tipos de dispositivos, como os reservatórios de detenção, para controlar a vazão de pico (URBONAS, 1999) e (EPA, 1999).

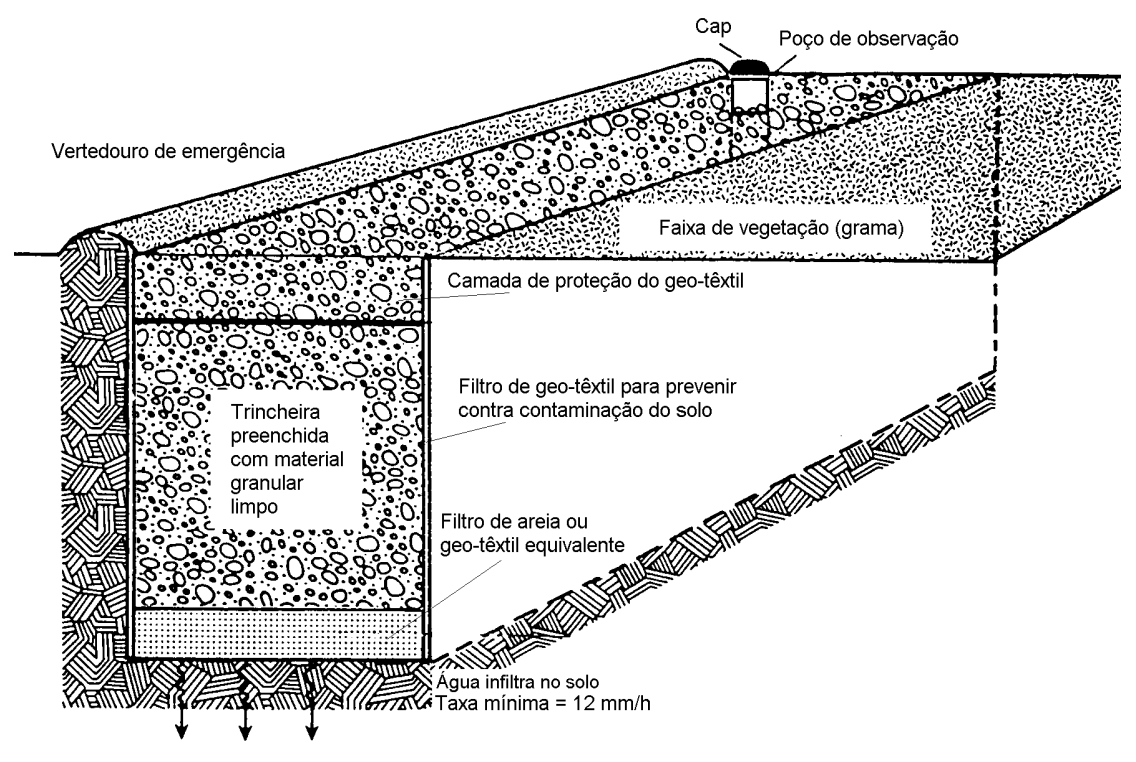

Figura 23 - Esquema típico de uma trincheira de infiltração Fonte : Souza e Goldenfum (1999) 
MIKKELSEN et al. (1996) citado por GRACIOSA (2004), diz que esses dispositivos são tipicamente de formato alongado e estreito, reduzindo a área de exposição que é supostamente obstruída por partículas finas após algum tempo de operação do sistema, aumentando ao mesmo tempo a relação entre a área efetiva de infiltração composta pelas paredes laterais e o volume de armazenamento.

LAWRENCE et al (1996), também citado por GRACIOSA (2004), salienta que a geometria alongada e estreita das trincheiras de infiltração é adequada à otimização da área ocupada pelas mesmas nos lotes urbanos e observa que essas estruturas requerem um pré-tratamento da água para reduzir o influxo de sólidos e a colmatação prematura, o que pode ser feito por uma manta geotêxtil removível e lavável.

Para URBONAS e STAHRE (1993), a aplicabilidade deste dispositivo depende de vários fatores e a escolha do local de implantação deve seguir alguns critérios como:

- A profundidade mínima sazonal do lençol freático e da camada impermeável devem estar a no mínimo 1,20 m de profundidade;

- O solo deve estar classificado como tipo A ou B do Soil Conservation Service ou a taxa de infiltração do solo saturado deve ser superior a $8 \mathrm{~mm} / \mathrm{h}$;

- Não devem ser instaladas em aterros ou terrenos com grande declividade;

- São indicadas para pequenas áreas de drenagem em lotes ou quarteirões.

As vantagens desse tipo de estrutura são praticamente as mesmas dos pavimentos permeáveis. Como desvantagens, TUCCI e MARQUES (2001) comentam a dificuldade de obtenção de informações sobre seu funcionamento a longo prazo, bem como de critérios de projeto e dimensionamento; GRACIOSA (2004) reforça a predisposição à colmatação e acrescenta que a eficiência do sistema é reduzida ao longo dos períodos chuvosos pela saturação do solo; CRUZ, ARAÚJO e SOUZA (1999) prevêem que a vida útil pode ser da ordem de 10 a 15 anos, mas que esses valores dependem dos cuidados tomados durante a construção da estrutura e das práticas de manutenção e informam que existe uma trincheira com 8 anos de 
operação, implantada em Boudeaux na França, que foi monitorada por um ano e meio, apresentando rendimento satisfatório.

SOUZA e GOLDENFUM (1999) estão realizando um estudo experimental e implantaram em solo com capacidade de infiltração de $9 \mathrm{~mm} / \mathrm{h}$, uma trincheira de infiltração com 10,00 x 0,80 de área, profundidade de $1,00 \mathrm{~m}$ e porosidade de enchimento de $50 \%^{82}$, cuja construção pode ser observada na figura 24 . O monitoramento é feito pela medição simultânea da vazão de entrada e do nível d'água dentro da trincheira ${ }^{83}$. Além do fato do experimento ser recente, alguns problemas de operação e medição do sistema tiveram que ser revistos e portanto, ainda não há apresentação de dados conclusivos. Porém, analisando duas medições do sistema após sua calibração, em eventos de pequena vazão observada, os autores verificaram resposta bastante rápida do nível da trincheira, considerando-a como evidência da eficiência do sistema.
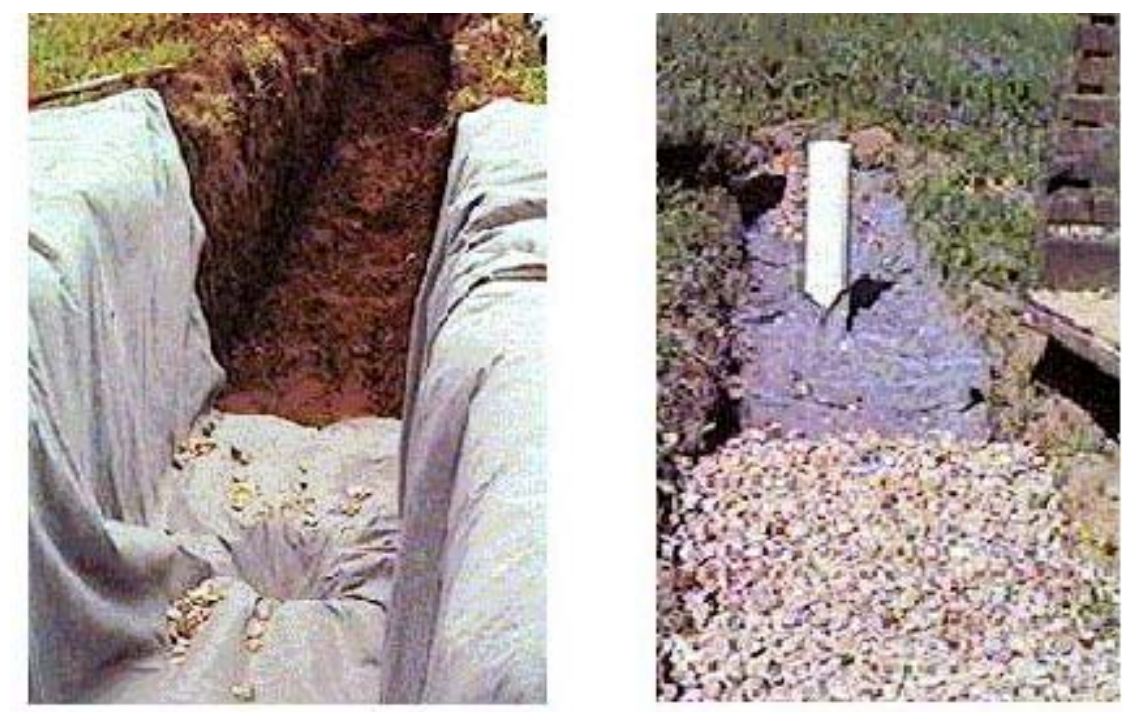

Figura 24 - Construção de trincheira de infiltração Fonte : Souza e Goldenfum (1999)

\footnotetext{
${ }^{82}$ Bacia de contribuição de $300 \mathrm{~m}^{2}$, coeficiente de escoamento superficial de 0,70 , período de retorno de 5 anos, volume total de $8,0 \mathrm{~m}^{3}$ e volume útil de $4,0 \mathrm{~m}^{3}$.

${ }^{83}$ Foram instalados dois tubos para posicionamento de linígrafos ou outros instrumentos de observação.
} 
$\mathrm{O}$ custo do sistema acima foi de $\mathrm{R} \$ 383,00$, considerando gastos com escavação, brita e geotêxtil, o que perfaz o valor de $\mathrm{R} \$ 1,28 / \mathrm{m}^{2}$ da bacia contribuinte.

Avaliação feita para um projeto de drenagem utilizando trincheiras de infiltração para a região metropolitana de Belo Horizonte, por Baptista et al (1998) apud CRUZ, ARAÚJO e SOUZA (1999), obteve uma redução de custos de 35\% em relação a um projeto convencional, porém foi observado que a utilização deste tipo de dispositivo é recente e ainda faltam elementos que possibilitem a avaliação de custos de instalação, operação e manutenção.

SCHULER et al. (1991) apud URBONAS (1999) relatou que 50\% das trincheiras de infiltração construídas no leste dos Estados Unidos não estavam funcionando, porém não indicou a natureza e as razões destas falhas.

No ano de 1990, para uma pesquisa conduzida pelo Estado de Maryland, também nos Estados Unidos, foram inspecionadas 88 trincheiras de infiltração e constataram que $51 \%$ delas mostravam sinais de falha parcial ou total.

Consequientemente, URBONAS (1999) concluiu que o uso deste tipo de alternativa deve ser desencorajada até que sejam adotados procedimentos de projeto consistentes e sugere a adoção de um pré-filtro antes da entrada na trincheira, além de uma investigação mais cuidadosa dos processos de escoamento subterrâneo.

Por outro lado FUJITA (1997) citado por GRACIOSA (2004) relata o sucesso na aplicação deste dispositivo em Tóquio no Japão ${ }^{84}$, esclarecendo que esta prática tem sido sistematicamente adotada em outras cidades japonesas não só para controle do escoamento superficial, como também para evitar a intrusão marinha, problema comum no país.

Conclui-se então, que a eficiência das trincheiras de infiltração é um assunto a ser melhor estudado, mas que evidencia correlações com características locais, principalmente no que se refere à qualidade da água do escoamento superficial.

\footnotetext{
${ }^{84}$ Onde foram instaladas $285 \mathrm{~km}$ de trincheiras de infiltração, em áreas públicas e privadas.
} 


\subsection{Ferramentas de Avaliação e Seleção}

MAKROPOULOS, BUTLER e MAKSIMOVIC (1999) estudando a utilização do SIG (sistema de informações geográficas) como ferramenta para avaliação e seleção da aplicabilidade de medidas de controle na fonte, propuseram uma forma de categorizar as características da bacia hidrográfica e cruzar estas informações com as características das medidas de controle, para encontrar a melhor alternativa em diferentes situações.

Para compor critérios de ponderação das informações, criaram uma tabela de pesos para itens que envolvem a seleção do tipo de medidas de controle na fonte (tabela 9) e categorizaram as características das bacias hidrográficas para processos de infiltração de acordo com a tabela 10. Os autores salientam que a importância relativa de cada componente é parte do julgamento técnico, possibilitando infinitas combinações, e embora os valores apresentados sejam razoáveis, não podem ser considerados como os únicos aplicáveis e devem ser entendidos como indicativos de aplicabilidade das medidas de controle na fonte.

Tabela 9 - Pesos para aplicação de diferentes medidas de controle

\begin{tabular}{|c|c|c|c|}
\hline \multirow{2}{*}{ Parâmetros } & \multicolumn{3}{|c|}{ Pesos } \\
\hline & Infiltração & Pavim. Poroso & Armazenamento \\
\hline Propriedades do solo & 0,25 & 0,225 & 0,05 \\
\hline Urbanização & - & 0,25 & - \\
\hline Espaço disponível & 0,20 & - & 0,25 \\
\hline Declividade & 0,20 & 0,15 & 0,20 \\
\hline Lençol freático & 0,20 & 0,25 & 0,05 \\
\hline Preço da terra & - & 0,1 & 0,25 \\
\hline Distância da rede & - & - & 0,15 \\
\hline Possibilidade de conexão $^{85}$ & 0,10 & - & - \\
\hline Distância do lançamento & 0,05 & 0,025 & 0,05 \\
\hline
\end{tabular}

(Fonte: Makropoulos, Butler e Maksimovic, 1999)

\footnotetext{
${ }^{85}$ Connectivity, em inglês.
} 
Tabela 10 - Categorização das características da bacia hidrográfica para análise de aplicabilidade de medidas de controle na fonte

\begin{tabular}{|c|c|c|c|}
\hline $\begin{array}{c}\text { Parâmetros que } \\
\text { afetam a infiltração }\end{array}$ & Pouco aplicável & $\begin{array}{c}\text { Medianamente } \\
\text { aplicável }\end{array}$ & Mais aplicável \\
\hline Uso do solo & $\begin{array}{c}\text { Urbanizado } \\
\text { (Área impermeável } \\
\text { maior que } 66 \% \text { ) }\end{array}$ & $\begin{array}{l}\text { Semi urbanizada } \\
\text { (Área impermeável } \\
\text { entre } 33 \% \text { e } 66 \% \text { ) }\end{array}$ & $\begin{array}{l}\text { Não urbanizada } \\
\text { (Área } \\
\text { impermeável } \\
\text { menor que 33\%) }\end{array}$ \\
\hline Tipo de solo & $\begin{array}{l}\text { impermeável } \\
\text { (ex. argila) }\end{array}$ & $\begin{array}{l}\text { Semi-permeável } \\
\text { (ex. areia) }\end{array}$ & $\begin{array}{c}\text { Permeável } \\
\text { (ex. cascalho) }\end{array}$ \\
\hline Declividade & $\begin{array}{c}\text { Alta } \\
\text { (maior do que 20\%) }\end{array}$ & $\begin{array}{c}\text { Média } \\
(\text { entre } 3 \% \text { e } 20 \%)\end{array}$ & $\begin{array}{c}\text { Leve } \\
(\text { menor que } 3 \%)\end{array}$ \\
\hline Preço da terra & Alto & Médio & Baixo \\
\hline Renda da população & Baixo & Médio & Alto \\
\hline $\begin{array}{l}\text { Profundidade do } \\
\text { lençol freático }\end{array}$ & $\begin{array}{c}\text { Pequena } \\
\text { (menos que } 3 \mathrm{~m} \text { ) }\end{array}$ & $\begin{array}{c}\text { Média } \\
\text { (entre } 3 \mathrm{~m} \mathrm{e} 10 \mathrm{~m} \text { ) }\end{array}$ & $\begin{array}{c}\text { Grande } \\
\text { (maior que } 10 \mathrm{~m} \text { ) }\end{array}$ \\
\hline $\begin{array}{l}\text { Distância do } \\
\text { lançamento }\end{array}$ & Perto & Médio & Longe \\
\hline Cobertura vegetal & Sem cobertura & Gramado & Natural \\
\hline $\begin{array}{l}\text { Profundidade da } \\
\text { camada impermeável }\end{array}$ & $\begin{array}{c}\text { Pequena } \\
\text { (menos que } 2 \mathrm{~m} \text { ) }\end{array}$ & $\begin{array}{c}\text { Média } \\
\text { (entre } 2 \mathrm{~m} \mathrm{e} 10 \mathrm{~m} \text { ) }\end{array}$ & $\begin{array}{c}\text { Grande } \\
\text { (maior que } 10 \mathrm{~m} \text { ) }\end{array}$ \\
\hline $\begin{array}{l}\text { Sistema de drenagem } \\
\text { existente }\end{array}$ & $\begin{array}{l}\text { Área de cobertura } \\
\text { maior que } 70 \%\end{array}$ & $\begin{array}{l}\text { Área de cobertura } \\
\text { entre } 30 \% \text { e } 70 \%\end{array}$ & $\begin{array}{c}\text { Área de } \\
\text { cobertura menor } \\
\text { que } 30 \%\end{array}$ \\
\hline $\begin{array}{l}\text { Disponibilidade de } \\
\text { espaço }\end{array}$ & Menor que $33 \%$ & Entre $33 \%$ e $66 \%$ & Maior que $66 \%$ \\
\hline $\begin{array}{l}\text { Área impermeável } \\
\text { diretamente conectada }\end{array}$ & Maior que $70 \%$ & Entre $30 \%$ e $70 \%$ & Menor que $30 \%$ \\
\hline
\end{tabular}

(Fonte: Makropoulos, Butler e Maksimovic, 1999) 
BRAUNE e WOOD (1999) elaboraram a tabela 11, enumerando a ordem de eficiência de algumas estruturas alternativas, onde nota-se que os reservatórios de armazenamento são os melhores classificados entre os dispositivos avaliados.

Para elaboração desta tabela, BRAUNE e WOOD (1999) utilizaram as informações fornecidas pelo estudo feito por URBONAS $(1997)^{86}$, que apresentou uma matriz de avaliação da eficiência das $\mathrm{BMPs}^{87}$, elaborada por especialistas no gerenciamento das águas de chuva em conjunto com Urban Drainage and Flood Control District em Denver, através da experiência obtida com a operação desses sistemas e ilustrada parcialmente na tabela $12^{88}$, onde a consistência de dimensionamento de projetos (CDP) fornece um indicativo da probabilidade de performance desses dispositivos.

Tabela 11 - Ordem de eficiência das BMPs

\begin{tabular}{|l|l|}
\hline \multicolumn{1}{|c|}{ Avaliação } & \multicolumn{1}{c|}{ Dispositivo } \\
\hline Muito eficaz & $\begin{array}{l}\text { Redução de áreas diretamente conectadas; } \\
\text { Reservatórios de detenção; } \\
\text { Reservatórios de retenção. }\end{array}$ \\
\hline Eficaz & Pavimentos permeáveis \\
\hline Moderadamente eficaz & Trincheira de infiltração \\
\hline
\end{tabular}

(Fonte: Braune e Wood, 1999 - simplificado)

\footnotetext{
${ }^{86}$ Refere-se a publicação entitulada "Chief Master Planning and South Platte River Program Urban Drainage and Flood Control District. Design and Selection Guidance for Structural BMPs", citado na referência bibliográfica do artigo escrito por BRAUNE e WOOD.

${ }^{87}$ Ver item 3.4.1.1 apresentado adiante.

${ }^{88}$ (5) representa o aspecto mais positivo e (-5), o aspecto mais negativo.
} 
Tabela 12 - Matriz de avaliação da eficiência das BMPs

\begin{tabular}{|c|c|c|c|c|c|c|c|}
\hline & Dispositivo & 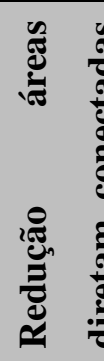 & 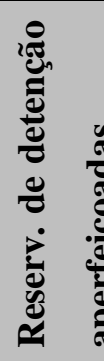 & 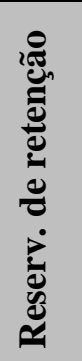 & 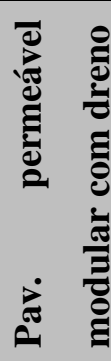 & 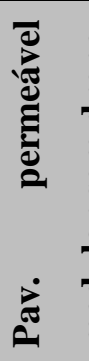 & 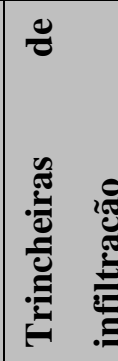 \\
\hline Con & ole de vazão & 5 & 5 & 5 & 5 & 5 & 4 \\
\hline Qua & dade da água & 4 & $4 *$ & 5 & 3 & 4 & 4 \\
\hline $\operatorname{Red}$ & ção do volume de escoamento & 5 & 1 & 1 & 1 & 4 & 4 \\
\hline $\begin{array}{l}\mathrm{Nec} \\
\mathrm{mar}\end{array}$ & $\begin{array}{l}\text { ssidade de operação e } \\
\text { tenção }\end{array}$ & -3 & -2 & -2 & -4 & -4 & -5 \\
\hline Sen & bilidade às condições locais & -4 & -2 & -3 & -2 & -5 & -5 \\
\hline Pot & cial de falhas & -2 & -2 & -1 & -2 & -4 & -5 \\
\hline & $\begin{array}{l}\text { Residencial baixo e médio } \\
\text { (regular) }\end{array}$ & 5 & 4 & 4 & 1 & 4 & 2 \\
\hline $\begin{array}{l}\tilde{0} \\
\mathscr{\theta}\end{array}$ & $\begin{array}{l}\text { Residencial alto e comercial } \\
\text { médio (regular) }\end{array}$ & 4 & 4 & 4 & 5 & 5 & 3 \\
\hline$:=$ & Comercial alto (regular) & 1 & 3 & 3 & 5 & 5 & 4 \\
\hline$\frac{\pi}{\frac{0}{0}}$ & $\begin{array}{l}\text { Alta densidade e ocupação } \\
\text { irregular }\end{array}$ & 2 & 2 & -1 & 4 & 4 & 2 \\
\hline & Hidráulica e hidrologia & 4 & 4 & 4 & 4 & 4 & 3 \\
\hline$\theta$ & Qualidade da água & 4 & $4^{89}$ & 4 & 3 & 4 & 4 \\
\hline $\begin{array}{l}\text { Pot } \\
\text { tem }\end{array}$ & $\begin{array}{l}\text { cial para aumentar a } \\
\text { eratura da água }\end{array}$ & -1 & -2 & -4 & -3 & -2 & -1 \\
\hline $\begin{array}{l}\text { Pot } \\
\text { águ }\end{array}$ & $\begin{array}{l}\text { cial para contaminação das } \\
\text { subterrâneas }\end{array}$ & -2 & -2 & -2 & -1 & -5 & -5 \\
\hline Pon & lação média & 1,36 & 1,21 & 1 & 0,89 & 0,59 & 0,1 \\
\hline Clas & ificação & 1 & 2 & 3 & 4 & 5 & 6 \\
\hline
\end{tabular}

(Fonte: Urbonas, 1997 apud Braune e Wood, 1999 - simplificado)

\footnotetext{
${ }^{89}$ Para reservatórios de detenção comum, os valores são mais baixos.
} 


\subsection{Cenário Internacional}

\subsubsection{Evolução das medidas de controle de cheias}

A percepção de que o simples afastamento do volume excedente para jusante não era uma solução satisfatória já foi detectada há muito tempo no cenário internacional (TUCCI e MARQUES, 2000).

Durante os anos 60, muitos artigos falavam sobre os efeitos da urbanização no aumento dos picos de vazões e volumes de cheias, assim como na mudança de características dos hidrogramas dessas áreas. Nos anos 70 , as atenções estavam voltadas para a redução da quantidade e gerenciamento do escoamento superficial, e como parte do movimento ambientalista do final dos anos 60 e início dos anos 70, o efeito da urbanização sobre a qualidade da água também esteve em foco na literatura técnica (McCUEN, WALESH e RAWIS, 1983).

Surgiram então, inúmeros artigos sobre planejamento, gerenciamento, métodos de dimensionamento e controle de escoamento superficial, relacionados tanto à quantidade quanto à qualidade da água (McCUEN, WALESH e RAWIS, 1983). Conceitos de soluções alternativas ou compensatórias foram promovidas especialmente na Europa e nos Estados Unidos (NASCIMENTO, ELLIS e DEUTSCH, 1999).

Nos anos 80, esses estudos continuaram com a inclusão de tópicos sobre legislação, política e "Melhores Práticas de Gerenciamento" - BMP (Best Management Practices). Nos anos 90, prosseguindo o processo, surgiu o "Desenvolvimento de Baixo Impacto" - LID (Low Impact Development) (LOUCKS, 1998) ou a minimização das áreas impermeáveis diretamente conectadas (US EPA, 1999). 


\subsubsection{Melhores Práticas de Gerenciamento - BMP}

O uso de práticas para controle e gerenciamento quantitativo e qualitativo das águas pluviais provenientes do escoamento superficial urbano voltados para controle na origem, como um grupo, é intitulado de Melhores Práticas de Gerenciamento ou em inglês, Best Management Practices - BMP, e envolvem medidas estruturais e não estruturais (McCUEN, WALESH e RAWIS, 1983); (URBONAS, 1999) e (US EPA, 1999).

Segundo URBONAS (1999), as BMPs estruturais foram concebidas para funcionar sem intervenção humana nos episódios de chuvas e promover tratamento passivo do escoamento superficial, enquanto que as BMPs não-estruturais formam um conjunto de práticas e normas institucionais voltadas à implementação de medidas de boas condutas/hábitos que reduzam ou previnam a poluição no meio ambiente urbano.

O autor ressalta que "muito já se conhece sobre as tecnologias atrás dessas práticas, muito ainda está emergindo e muito está para ser aprendido" e acrescenta que atualmente, a maioria dessas medidas de controle são utilizadas sem o total entendimento das limitações e eficácia em condições práticas, em oposição às expectativas das legislações ou às opiniões e prognósticos acadêmicos.

Nos Estados Unidos, um programa nacional desenvolvido pela EPA Environmental Protection Agency - obriga todas as cidades com mais de 100 mil habitantes a estabelecer programas de utilização de BMP. Recentemente, numa segunda fase deste programa, a exigência tem sido estendida para cidades com população inferior à mencionada. Por solicitação deste programa, os municípios devem demonstrar que estão avançando e buscam atingir as metas estabelecidas num Plano de Drenagem Urbana previamente estabelecido. Esse processo contribui para reduzir a poluição difusa e tem como penalidade potencial, ação judicial da EPA contra o município (TUCCI e MARQUES, 2001).

A implantação de reservatórios de detenção de cheias e a adoção de outros preceitos de BMP são práticas bastante comuns, principalmente em países desenvolvidos como os Estados Unidos, onde constam em legislações específicas de 
vários estados: Maryland, Colorado, Illinois, Indiana, Virgínia, Columbia, etc (URBONAS, 1999) e (LOUCKS, 1998).

Entretanto, este tipo de dispositivo não está restrito aos países desenvolvidos, sendo citado em países como a África do Sul, Argentina, Austrália, China, Malásia, Servia e Montenegro, etc. (LOUCKS, 1998); (BRAUNE, 1999) e (MAKROPOULOS, BUTLER e MAKSIMOVIC, 1999).

\subsubsection{Desenvolvimento de baixo impacto - LID}

O Desenvolvimento de Baixo Impacto ou Low Impact Development -LID, faz parte das BMPs e é uma abordagem alternativa de gerenciamento do escoamento superficial, onde o controle é fundamentalmente feito através da mudança na forma convencional de concepção de projetos, procurando criar ambientes funcionais integrados que imitem as funções hidrológicas naturais da bacia de drenagem, utilizando técnicas de infiltração, filtração, armazenamento, evaporação e retenção para desconectar áreas impermeáveis diretamente conectadas ou potencializar os processos citados (figura 25) (LOUCKS, 1998).

A criação desse ambiente funcional com menor impacto no meio ambiente utiliza projetos "inteligentes" com tecnologias apropriadas que alcançam um melhor balanço entre conservação, desenvolvimento, proteção ao meio ambiente, saúde pública e qualidade (LID CENTER, site), passando por um processo seqüencial de tomada de decisões, repetidas diversas vezes, até a determinação de uma alternativa apropriada que garanta uma redução aceitável do volume de escoamento superficial (LOUCKS, 1998), minimizando a necessidade de implantação de estruturas de drenagem.

Estudos de casos e programas pilotos realizados nos Estados Unidos, demonstram uma redução de no mínimo 10 à $25 \%$ nos custos associados à urbanização, tarifas e manutenção para projetos residenciais que fazem uso das técnicas relacionadas ao LID (LID CENTER, site) e (LOUCKS, 1998). Além disso, existe uma valorização maior do imóvel e melhor aproveitamento do terreno por não 
haver necessidade de implantação de reservatórios de detenção/retenção ou pela redução de suas dimensões (LID CENTER, site).

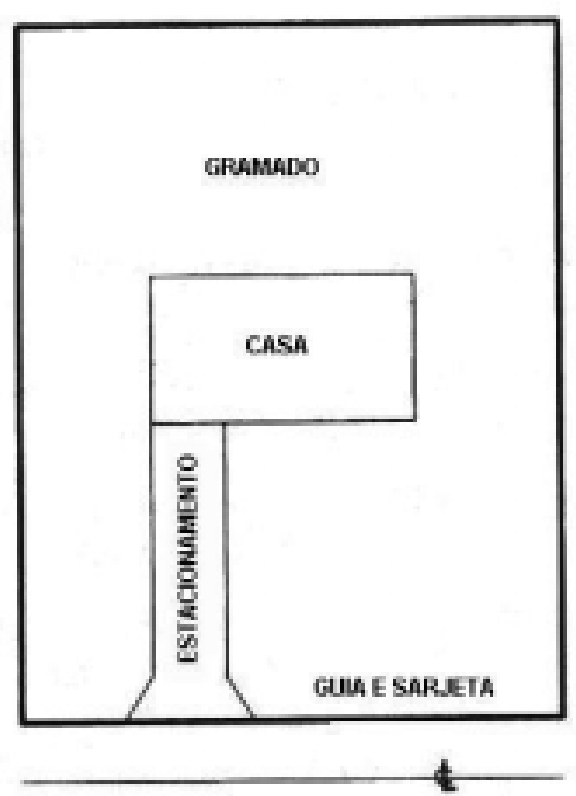

CONCEPÇÃO CONVENCIONAL

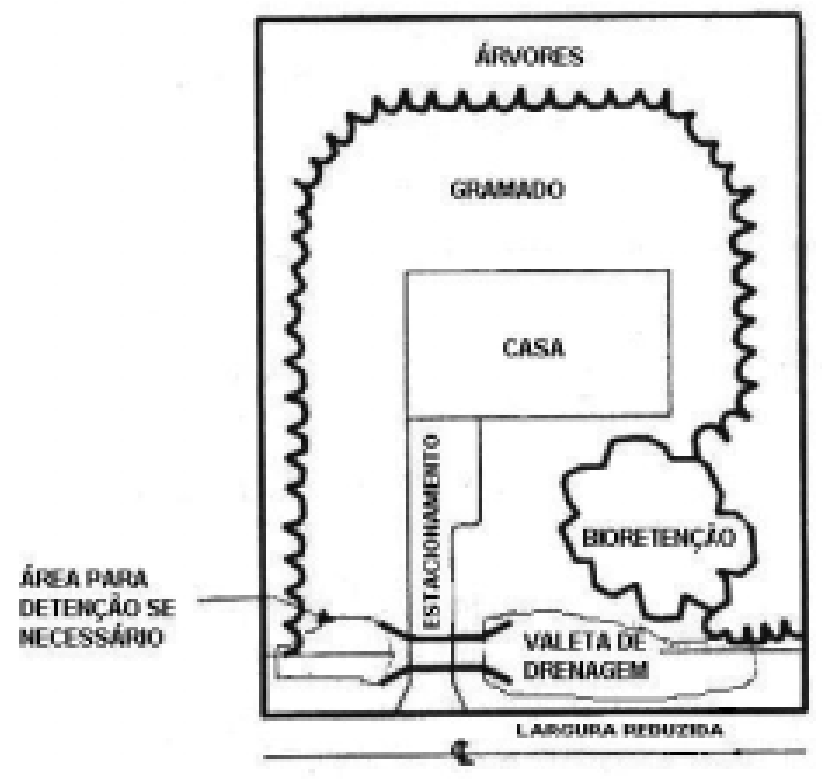

CONCEPÇÃO COM DESENVOLVIMENTO DE BAIXO IMPACTO

Figura 25 - Comparação entre concepção convencional e concepção com técnicas de desenvolvimento de baixo impacto -LID

Fonte : Loucks (1998)

O sucesso dos LID's estão muito mais relacionados ao conhecimento, habilidade e criatividade dos projetistas do que com o que os proprietários fazem ou deixam de fazer. A chave do sucesso é assegurar que as soluções sejam atrativas e percebidas pelos proprietários como elementos de agregação de valor (LID CENTER, site). 


\subsubsection{Estudos e experiências}

BRAUNE e WOOD (1999) em seu trabalho sobre a aplicação das melhores práticas de gerenciamento (BMP) para controle quantitativo e qualitativo do escoamento urbano, concluíram que o uso e seleção de soluções alternativas específicas dependem das condições locais e dos objetivos, como controle da qualidade da água, mitigação de inundações, proteção das águas subterrâneas, etc, e que em muitos casos, em função das muitas intenções e necessidades, várias soluções alternativas são conjugadas parar obter um tratamento integrado, criando medidas econômicas capazes de minimizar os impactos da urbanização sobre a quantidade e qualidade da água. Anteriormente à escolha e utilização de soluções alternativas, os autores preconizam a utilização de sistemas de avaliação de riscos para identificação, quantificação e classificação das áreas a serem atendidas prioritariamente e informam que esta metodologia é bastante utilizada na Austrália (BODYCOT, 1986 apud BRAUNE e WOOD, 1999).

AZZOUT, BARRAUD e ALFAKIH (1995) desenvolvem um sistema de suporte à decisão para gerenciamento das águas de chuva através de medidas alternativas (BMP) e esclarecem que embora soluções alternativas ofereçam possibilidades importantes de desenvolvimento, de custo e de proteção contra enchentes, as escolhas dessas estruturas (sistemas de detenção e infiltração) são freqüentemente feitas com pouco entendimento das limitações locais e de suas possibilidades de uso, levando a gastos extras e ao mal funcionamento dos sistemas de drenagem, e por isso são ainda pouco utilizadas.

O diagnóstico desta situação permitiu a identificação de duas causas principais e justificou a necessidade de criação de um sistema de suporte à decisão ora em desenvolvimento pelos autores.

A primeira causa apontada é uma grande quantidade de conhecimento disperso e mal organizado. Os autores reconhecem que pesquisas e experiências são desenvolvidas em várias áreas correlatas (hidrologia, estrutura, mecânica dos solos, etc.), porém identificam uma lacuna na absorção do conhecimento pela falta de conexão entre as diversas áreas, devido à grande heterogeneidade das fontes de conhecimento e à dificuldade de inter-relacionamento. Segundo eles, poucas 
pesquisas têm sido eficientes do ponto de vista da difusão de conhecimento e são julgadas freqüentemente por critérios contraditórios, de acordo com a área onde estão sendo desenvolvidas. A falta de coordenação entre pesquisas leva a sérios desperdícios de conhecimento e ao empobrecimento do potencial de desenvolvimento dessas soluções.

A segunda causa, considerada um problema de multiplicidade, é a complexidade de fatores que influem na escolha das soluções alternativas:

- Multiplicidade de gerenciamento: podem ser feitos por bacias hidrográficas, por municípios, por estados, etc. com decisões baseadas em múltiplas tendências;

- Multiplicidade de ponto de vista: são relativas à área de estudo (geologia, hidráulica, biologia, economia, direito, etc.) assim como do estágio do projeto (dimensionamento, execução, manutenção). Este tipo de escolha necessita de especialistas de várias áreas e podem ser contraditórios e muito diferentes entre si;

- Multiplicidade de estratégias possíveis: existem muitas técnicas diferentes (infiltração, armazenamento, educação, etc.) e estratégias (atuação pontuais, localizadas, dispersas, etc.);

- Multiplicidade de funções e usos extras: as soluções alternativas são por natureza multifuncionais, podendo compatibilizar uma infinidade de usos e funções diversas (controle de cheias, recreação, abastecimento, etc.).

SIEKER (1998) apresenta um dispositivo de controle do escoamento na fonte que combina diferentes funções e está se espalhando por toda a Alemanha, sendo denominado como um sistema valeta - trincheira de infiltração, cujo projeto e dimensionamento é feito para maximizar a infiltração do escoamento superficial, através de um armazenamento de curto período na canaleta e um armazenamento de longo período na trincheira (figuras 26 e 27). 


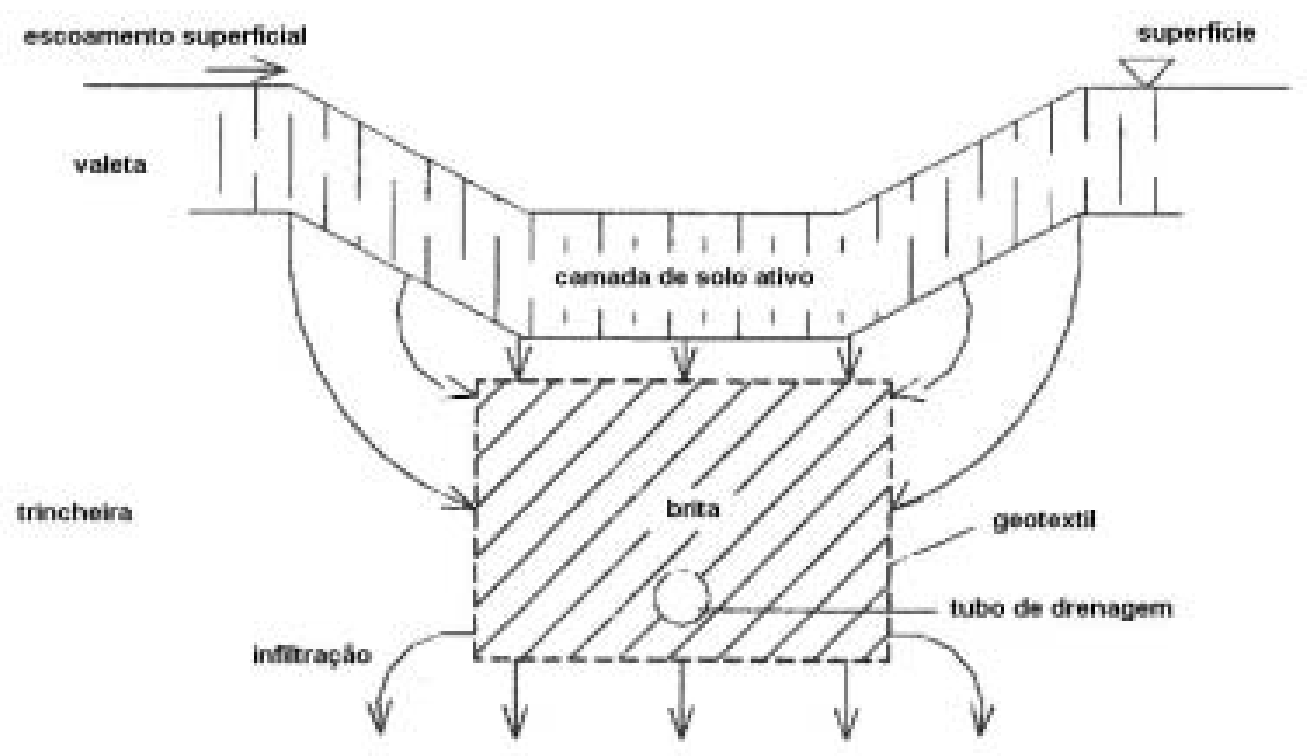

Figura 26 - Sistema valeta - trincheira de infiltração (seção transversal) Fonte : Sieker (1998)

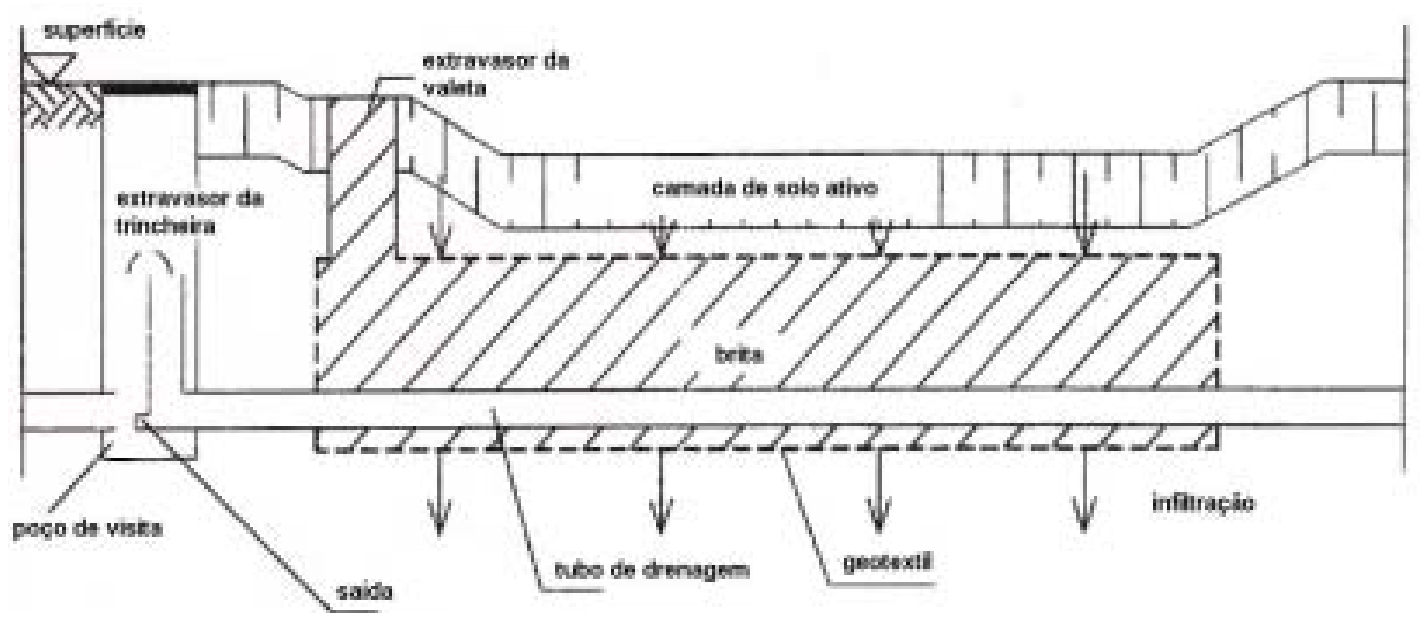

Figura 27 - Sistema valeta - trincheira de infiltração (seção longitudinal) Fonte : Sieker (1998) 
A valeta gramada e rasa ${ }^{90}$ constitui-se em uma espécie de pequeno reservatório de detenção que recebe a contribuição de uma sarjeta, sendo instalada em solo com permeabilidade mínima de $10^{-5} \mathrm{~m} / \mathrm{s}$ para garantir o processo de infiltração total no prazo de 3 horas após o término do evento chuvoso. De acordo com a experiência alemã, o volume de armazenamento na valeta pode ser estimado utilizando escoamento superficial de $20 \mathrm{~mm}$ procedente das áreas impermeáveis.

A trincheira de infiltração debaixo da valeta gramada ${ }^{91}$, é projetada como uma trincheira convencional e formada por um volume prismático de material granular envolto por manta geotêxtil. Durante os eventos típicos, as trincheiras são alimentadas somente pelo fundo da valeta gramada, porém para eventos mais rigorosos está previsto um extravasor ${ }^{92}$ que conduz o escoamento para o interior da trincheira de infiltração.

O dispositivo descrito é utilizado em áreas privadas e públicas, e até mesmo em canteiros de avenidas. Como restrições ao uso pode-se citar superfície de drenagem muito inclinada e falta de espaço, apesar de ser um dispositivo flexível e de fácil adaptação às condições locais. Como principal vantagem apresenta a possibilidade de favorecer a desconexão de áreas impermeáveis em projetos novos ou reformas.

SIEKER (1998) comenta também que na reurbanização da cidade de Hameln, onde o sistema de drenagem estava sobrecarregado e havia a intenção de desconectar parte da área impermeável diretamente conectada, os proprietários foram motivados a participar voluntariamente pelo pagamento de $10,00 \mathrm{DM}$ por $\mathrm{m}^{2}$ de superfície não diretamente conectada e foram beneficiados com um desconto de $1,00 \mathrm{DM}^{93}$ por $\mathrm{m}^{2}$ /ano sobre a taxa normalmente imposta pela cidade para cobrir custos de drenagem. Receberam também, durante a elaboração dos projetos, orientações sobre problemas administrativos e de construção por um grupo composto por engenheiro e paisagista.

\footnotetext{
${ }^{90}$ Com profundidade máxima de $30 \mathrm{~cm}$ e taludes laterais de 1:3 para facilitar a manutenção.

${ }^{91}$ Entre o fundo da canaleta e a parte superior da trincheira é previsto uma camada de areia.

${ }_{92}^{92}$ Tubo preenchido com material granular.

${ }^{93}$ Aproximadamente US\$ 27,00 e US\$ 2,70, respectivamente.
} 
SIEKER e KLEIN (1998) em um estudo sobre a possibilidade de utilização de BMPs em uma bacia urbanizada ${ }^{94}$ em Berlim, na Alemanha, utilizando SIG, concluíram que mesmo em áreas densamente urbanizadas é possível desconectar facilmente $30 \%$ da área impermeável, demonstrando que os sistemas de drenagem sempre podem ser aperfeiçoados.

URBONAS (1999) por outro lado, observa que se mal utilizado a desconexão de áreas impermeáveis pode causar a proliferação de mosquitos, criar dispositivos inadequados, propiciar processos de erosões, etc.

MAKROPOULOS, BUTLER e MAKSIMOVIC (1999) citam uma pesquisa feita em Belgrado ${ }^{95}$, na Sérvia e Montenegro, onde a solução mais barata e ambientalmente amigável encontrada para os problemas de inundações foi a conjugação da reabilitação do sistema existente, a detenção seletiva nos canais, o aumento do controle na fonte através da infiltração, e a construção de "wetlands" para melhorar a qualidade da água. Os autores propõem a adoção de sistemas similares como medidas, pelo menos temporárias, para mitigar inundações e controlar a qualidade da água em paises em desenvolvimento.

SPIRN (1995) apresenta a cidade de Woodland ${ }^{96}$, no Texas como modelo de projeto de drenagem, pois neste local, o gerenciamento das águas pluviais representou o fator crítico de viabilidade do empreendimento e buscou-se ao mesmo tempo, soluções harmônicas de integração entre desenvolvimento e meio ambiente. Foram implantados então, dois subsistemas: um que estoca e absorve as águas das chuvas freqüentes, explorando solos com boa capacidade de infiltração para absorver as águas, e o outro, que drena a água das grandes tempestades, através dos baixios arborizados e vales de cursos d'água para escoamento e prevenção de enchentes a jusante (figura 28). O uso das várzeas arborizadas existentes para fins de drenagem assegurou também um sistema interligado de parques e trilhas através da cidade e economizou milhões de dólares.

\footnotetext{
94 com aproximadamente $22 \mathrm{~km}^{2}$

95 na cidade de médio porte de Novi Sad, caracterizada por uma urbanização não uniforme, tendo o Rio Danúbio como limite entre a cidade velha com o mais antigo sistema de drenagem da região, e a cidade nova com ocupação irregular da periferia e atividade industrial.

${ }^{96}$ Woodland é uma cidade nova, ao norte de Houston, implantada nos bosques de pinheiros de 8 ha, em terreno de predominância bastante plana, com extensas áreas de solo com baixa permeabilidade.
} 


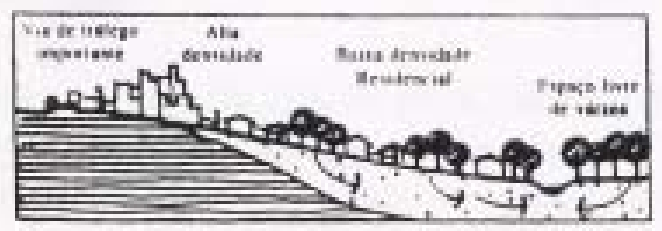

A) Usos da ierre que melhocam a efcarga da igua de escramento

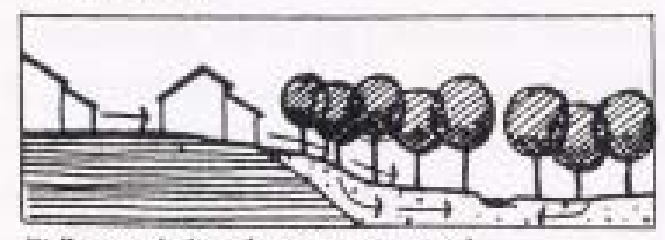

b) Recarga da ifua de escoumeisu em suls

$\mathrm{em}$ declive

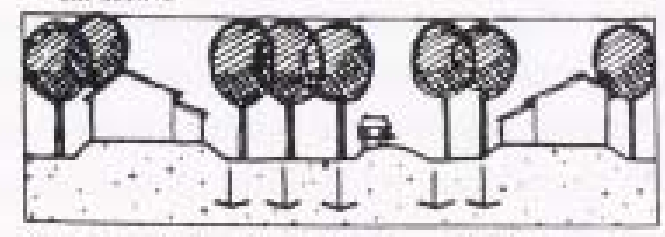

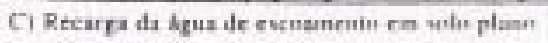

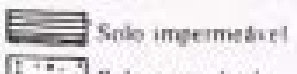

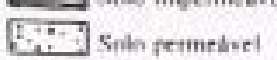

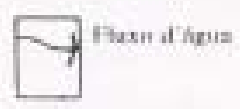

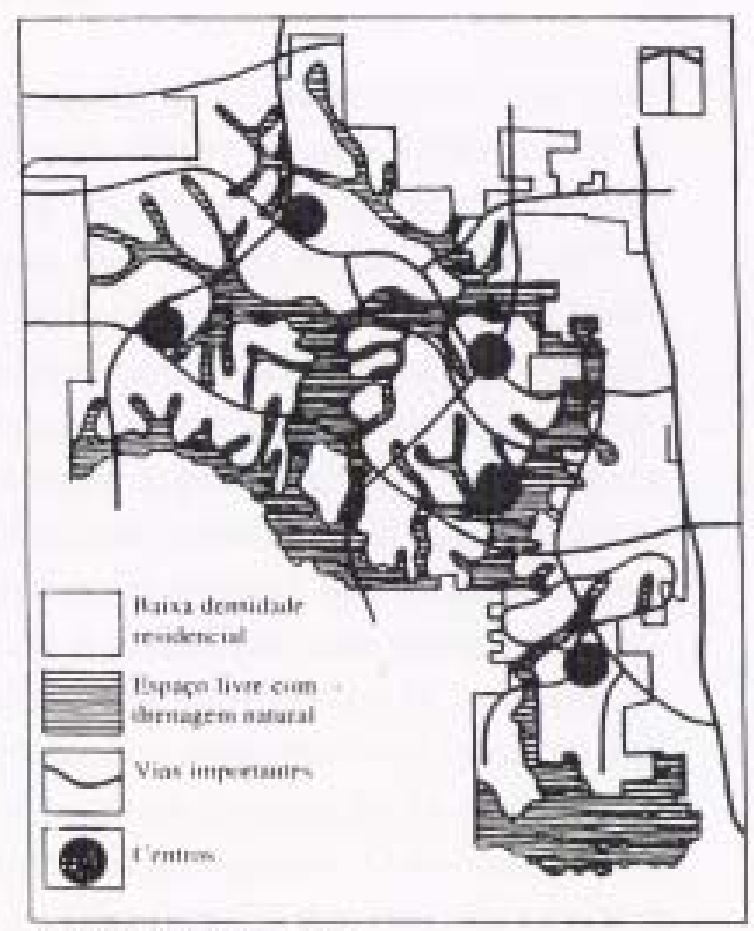

In Than ak Woullanke. Tteas

Figura 28 - Sistema de drenagem de Woodland

Fonte : Spirn (1995)

Até um certo tempo atrás, a legislação do Reino Unido, segundo NASCIMENTO, ELLIS e DEUTSCH (1999), exigia para novos projetos, a manutenção das vazões de picos nos mesmos valores existentes antes da urbanização e solicitava que essa atenuação fosse realizada apenas através de armazenamento local. Só mais recentemente, houve a extensão para outras formas de controle na fonte, como a infiltração.

No Japão, observa-se não somente uma preocupação intensa com a qualidade da água dos córregos e rios, mas também com a disposição local das águas das chuvas. Desta forma, a figura 29 ilustra a utilização de material de construção reciclado, proveniente de demolição, para a composição de dispositivos de retenção e infiltração (JICA, 1996). 


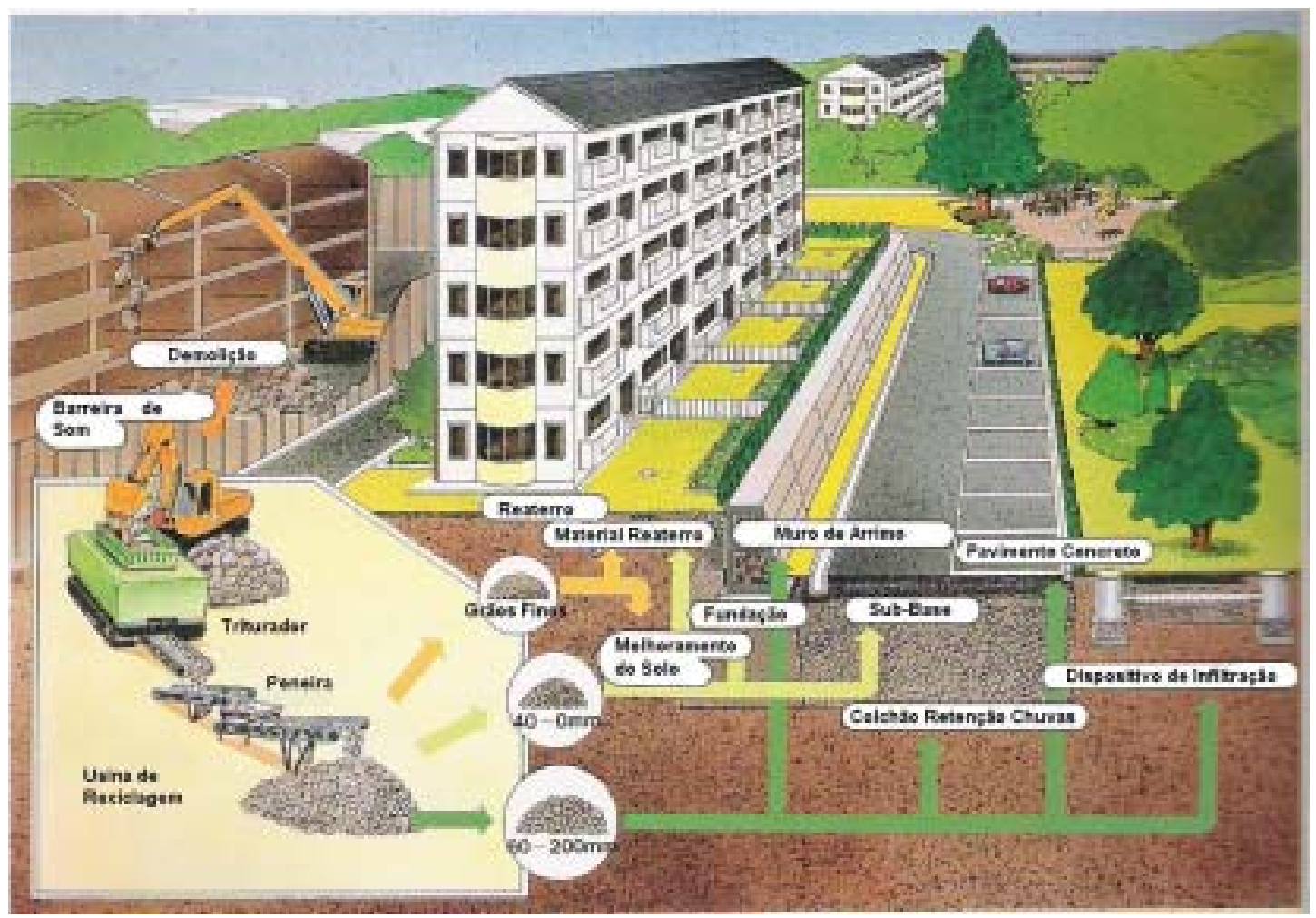

Figura 29 - Utilização de material reciclado em estruturas alternativas Fonte : JICA (1996)

ANDOH (1994) cita exemplos de revisões de estratégias adotadas em York Toronto, em Wadley Road - Londres e em Evanston - Ilinóis, onde foram possíveis a redução considerável dos gastos com sistemas de drenagem através da adoção de soluções alternativas, esclarecendo que essas soluções podem ser implementadas por fases, facilitando sua utilização.

Segundo o autor acima, a evolução das práticas correntes e os fatores sócioeconômicos envolvidos, terminam recomendando a utilização de estratégias alternativas de controle na fonte para a drenagem urbana de países em desenvolvimento, devido aos seus benefícios e a economia resultante, pois esses países não serão capazes de perpetuar sistemas desenvolvidos pelos conceitos clássicos, necessitando encontrar soluções econômicas. Para o autor, os principais problemas para deslanchar a adoção dessas estratégias são a tradição e questões 
institucionais, ressaltando a necessidade de mudança de paradigma e revisão dos arranjos institucionais.

Novamente, a melhor escolha recairá na associação das alternativas disponíveis, de forma a garantir as características naturais existentes e manter as condições de pré-urbanização, levando em consideração aspectos locais e experiências anteriores.

\subsubsection{Situação atual}

Nos países de primeiro mundo, a ênfase das questões de drenagem urbana situa-se notoriamente nos aspectos relativos à qualidade da água coletada, já que as ações visando o controle das inundações encontram-se bastante adiantadas.

TUCCI e MARQUES (2001) informam que, para controle quantitativo da drenagem urbana nos países desenvolvidos, foi priorizado o controle através de medidas não-estruturais, que obrigam a população a controlar na fonte os impactos devido à urbanização e que atualmente, o principal problema é o controle da poluição difusa das águas pluviais.

"A experiência americana mostra que se forem captados e tratados os primeiros $15 \mathrm{~mm}$ de escoamento superficial em todos os eventos, estará sendo tratado entre 80 e $90 \%$ do volume total escoado no ano" (ASCE, 1992 apud TUCCI, PORTO e BARROS, 1995).

Segundo exposições feitas por palestrantes da HYDROAID (2004), apesar de não constar ainda na legislação vigente, a comunidade econômica européia acena para o armazenamento e tratamento obrigatório dos primeiros $15 \mathrm{~mm}$ de chuva, considerados os mais poluentes por serem caracterizados basicamente pela água de lavagem das superfícies (first flush).

Em particular na Itália, após a reorganização dos serviços de água através da chamada "Legge di Galli" de 1994 e a criação dos "âmbitos territoriais ótimos" (ATO), está sendo estudada a desativação de algumas pequenas estações de tratamento de esgoto para otimização dos sistemas e a intenção é reutilizá-las, depois 
de algumas adequações, para o tratamento dos primeiros $15 \mathrm{~mm}$ de chuva (HYDROAID, 2004).

Atualmente em Turim, apesar dos sistemas de esgotamento sanitário e de coleta de águas pluviais serem separados, toda água coletada proveniente das chuvas é encaminhada para as estações de tratamento de esgotos, que são dimensionadas para comportar uma vazão cinco vezes maior do que a vazão máxima horária proveniente dos sistemas de esgotamento sanitário (HYDROAID, 2004).

Entretanto no Brasil e nos países em desenvolvimento, a questão do controle quantitativo das enchentes ainda é limitado e prioritário (CANHOLI, 1995) e (TUCCI e MARQUES, 2001).

PARKINSON et al (2003) atribuem este fato a existência de lançamento de esgoto "in natura" nos corpos de água no Brasil, o que torna o controle qualitativo da água pluvial secundária, porém observa-se a inversão deste cenário para locais onde o nível de tratamento é alto, como no caso do Lago Paranoá, em Brasília.

A evolução da finalidade das estruturas alternativas, especialmente dos reservatórios de detenção/retenção no gerenciamento da drenagem urbana, pode ser observado na figura 30 (McCUEN, WALESH e RAWIS, 1983), segundo o qual, o Brasil ainda estaria na primeira fase. Entretanto, mesmo sem ter equacionado os problemas da primeira fase, já se caminha para as demais fases por anseios da própria sociedade brasileira.

Nos Estados Unidos, onde já existe uma cultura de participação social nas questões do desenvolvimento urbano e onde o processo de conscientização e educação ambiental são mais arraigados, estruturas alternativas de drenagem urbana, inclusive reservatórios de armazenamento, já são implantados pelos próprios cidadãos, através de iniciativas populares, voluntariamente ou por solicitação aos governantes.

Relatos demonstram a existência de diversos tipos de acordos entre proprietários e governantes, tanto para implantação dessas estruturas, quanto para operação e manutenção compartilhadas.

Há também um grande esforço na divulgação dos conceitos, na normatização de procedimentos e na disponibilização das informações, havendo farto material na internet. Porém, ao consultar e acessar essas informações deve-se observar os 
objetivos dos dispositivos, as diferenças regionais e as mudanças nos ciclos hidrológicos, além de aspectos culturais.

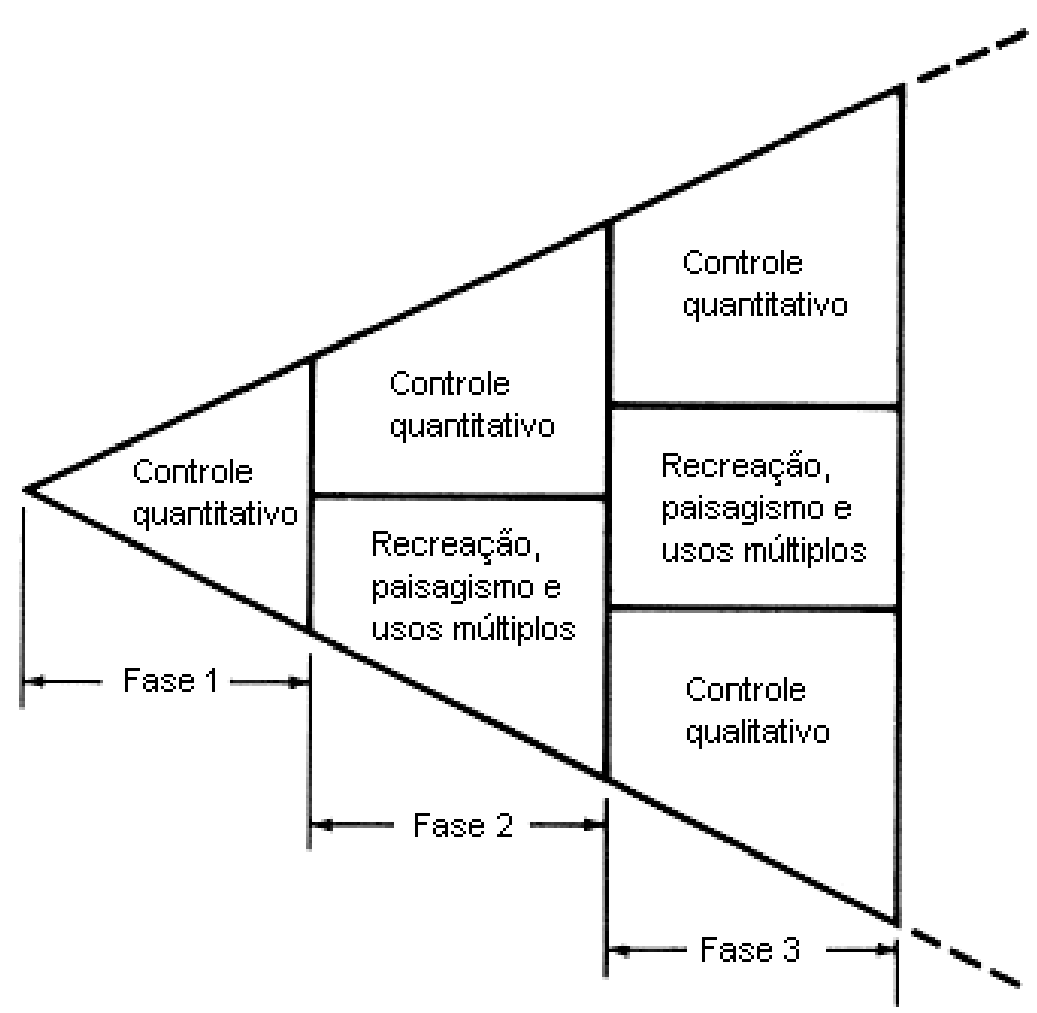

Figura 30 - Evolução do uso dos reservatórios de detenção/retenção Fonte: McCuen, Walesh e Rawis (1983) 


\section{RESERVATÓRIOS DE DETENÇÃO}

\subsection{Definição e Utilização}

Reservatórios de detenção são dispositivos de drenagem urbana destinados ao armazenamento de um certo volume de águas pluviais, com o intuito de reduzir o pico dos hidrogramas de cheias e retardar a taxa de resposta do escoamento superficial, conforme figura 31 (TUCCI, 1997) e (WANIELISTA, 1990).

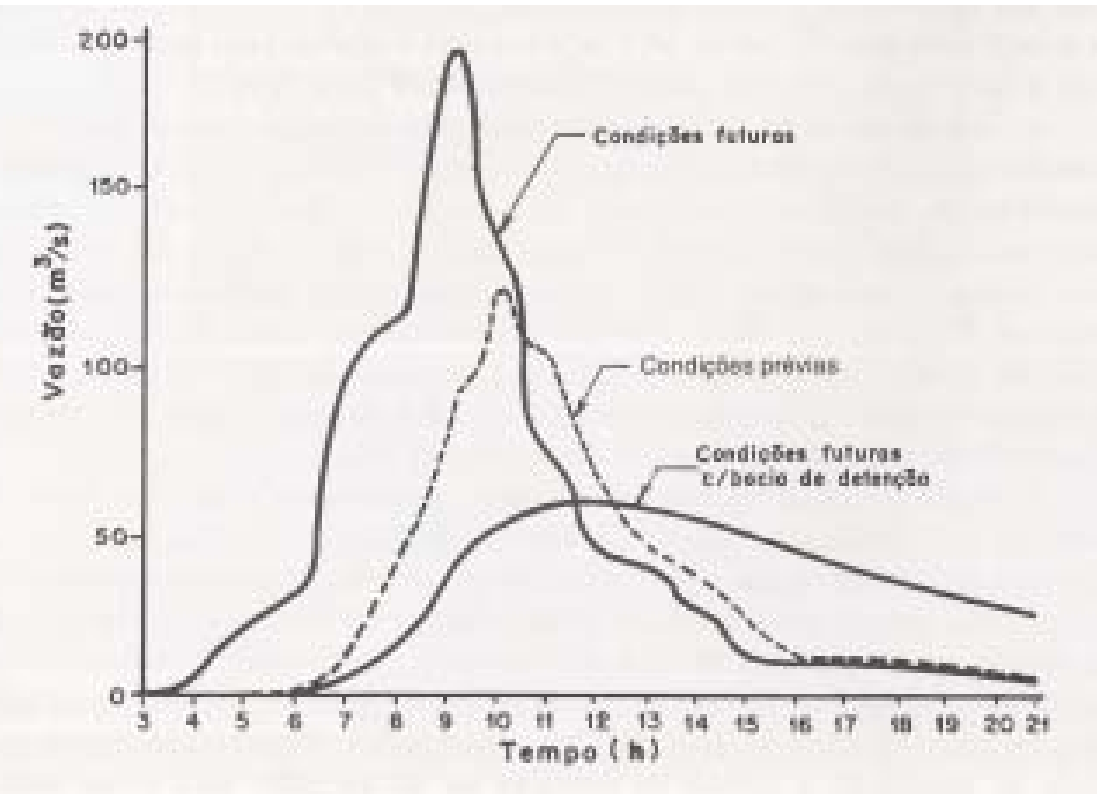

Figura 31 - Hidrogramas típicos de bacias de detenção Fonte : Tucci (1997)

Como não há no meio técnico um consenso sobre a terminologia utilizada, principalmente para a denominação das estruturas de armazenamento de cheias, e a mesma nomenclatura pode ser utilizada com diferentes significados, gerando grandes confusões (OLIVEIRA, 2004) e (US EPA, 1999), ressalta-se que o termo 
"reservatório de detenção", utilizado neste trabalho, significa: estruturas de armazenamento temporário que após os eventos chuvosos permanecem secas.

O objetivo das bacias ou reservatórios de detenção é minimizar o impacto hidrológico da redução da capacidade de armazenamento natural da bacia hidrográfica, provocada principalmente pelo aumento das áreas impermeabilizadas pela urbanização, redistribuindo as vazões ao longo de um tempo maior, através do conveniente armazenamento dos volumes escoados, formando um volume útil temporário e promovendo o amortecimento dos picos de drenagem desde a entrada no sistema até sua disposição final (TUCCI, PORTO e BARROS, 1995); (CANHOLI, 1995) e (TUCCI, 1997).

Os reservatórios de detenção podem ser implantados na macrodrenagem, na microdrenagem e em loteamento e lotes.

A adoção de reservatório de detenção na macrodrenagem, de forma geral, é concebida ou deveria ser, pelos planos diretores de macrodrenagem urbana após cuidadosos estudos da bacia hidrográfica, como acontece em São Paulo ${ }^{97}$, onde os problemas de escoamento da drenagem são totalmente interdependentes e complexos (CANHOLI, 2000).

Genericamente, os reservatórios de detenção de grande porte, conhecidos como piscinões, são medidas estruturais corretivas, que interferem em áreas densamente povoadas, com altos custos de construção e desapropriações, necessitando de áreas convenientes para sua implantação e de financiamentos (TUCCI, PORTO e BARROS, 1995) e (GRACIOSA, 2004). Podem ainda ser objeto de rejeição por parte dos moradores (PORTO E FILHO, 2004), além de envolver questões de ordem ambiental devido a carga de lixo transportada e às ligações clandestinas de esgoto (TUCCI e MARQUES, 2000) e (CRUZ et al, 1998 apud GRACIOSA, 2004).

O DAEE esclarece em seu site, que esses "piscinões" são adotados como solução de curto prazo pelo Plano Diretor de Macrodrenagem da Bacia do Alto Tietê, em razão da impossibilidade prática de aumento da capacidade de descarga de alguns

${ }^{97}$ Os planos elaborados a partir de 1997 para a bacia do Alto Tamanduateí, prevêem a construção de 46 reservatórios tipo "piscinões” (DAEE, 1999), dos quais 12 já estavam construídos em 2002 (SANTOS, 2002). 
dos seus principais rios, face aos incrementos de vazão ocasionadas pela crescente e forte urbanização. Esta solução tem se mostrado eficaz por produzir efeitos imediatos após a conclusão das obras, pois "o piscinão não é nada mais que a criação de uma nova várzea, uma área que possa acumular água" e uma alternativa de controle do escoamento superficial obtida através da tentativa de recuperação do amortecimento perdido.

Atualmente além de São Paulo, cidades como Porto Alegre, Belo Horizonte, Curitiba, Natal, Maceió e Teresina já contam com esse dispositivo de drenagem urbana (FIORAVANTI, 2004) e (NASCIMENTO, ELLIS e DEUTSH, 1999).

Como parte da microdrenagem, seguem em linhas gerais os esclarecimentos prestados para sua adoção nos sistemas de macrodrenagem, exceto pelo seu menor vulto e conseqüentemente, facilidade de implantação.

Implantados em lotes ou loteamentos, recebem em inglês a denominação de “on-site stormwater detention”, ou simplesmente OSD, e são normalmente utilizados quando existe uma legislação específica restringindo o aumento da vazão máxima, como forma de preservar as condições preexistentes. Observa-se que a legislação específica pode ser apenas o desdobramento dos estudos feitos pelos planos diretores e neles citados como medida preventiva a ser adotada para a bacia hidrográfica.

Segundo CRUZ e AGRA (2001) e CRUZ, ARAÚJO e SOUZA (2003), os microreservatórios são estruturas de armazenamento distribuídas, colocadas no interior de lotes urbanos para abater as vazões de pós-ocupação e manter as condições de pré-urbanização, atenuando o pico dos hidrogramas de saída e possibilitando a recuperação da capacidade de amortecimento perdida pela bacia devido à impermeabilização, principalmente pelo controle da vazão de saída. Esses microreservatórios podem ser aplicados em pequenos espaços livres, como praças, jardins e quintais, possuem a vantagem de uma implementação mais simples e rápida e são dimensionados através de metodologias simplificadas.

PORTO e FILHO (2004) ressaltam que a implantação de microreservatórios é facilitada pelas suas pequenas dimensões, mas que isso não torna a tarefa mais fácil.

TASSI (2002) comenta que o impacto gerado por esses dispositivos de controle na fonte sobre a macrodrenagem, ainda é um assunto pouco estudado e que 
medidas que isoladamente podem ser aceitáveis, quando analisadas de forma conjunta, podem ser técnica ou economicamente ineficientes e avalia que, dependendo dos critérios de dimensionamento, o custo global (microreservatórios + redes) pode ser maior do que aqueles obtidos através dos métodos clássicos. Além disso, acrescenta que normalmente o estudo deste tipo de dispositivo tem uma análise pontual, não considerando a combinação de efeitos resultante de ações distribuídas.

A PMSP/FCTH (1999) considera que a implantação indiscriminada de obras de armazenamento numa dada bacia para solucionar problemas localizados, pode levar a efeitos interativos inesperados e deve ser evitada, destacando que o uso destes dispositivos leva ao surgimento de uma falsa sensação de segurança, ao mesmo tempo em que pode causar o efeito adverso do sincronismo dos picos de cheias das sub-bacias, levando a descargas maiores do que as existentes (figura 32).

CRUZ, TUCCI e SILVEIRA (2000) lembram que o controle em lotes reduz somente parte dos impactos devido à urbanização, porque restam ainda ruas, calçadas e áreas públicas, mas que estes espaços podem também ser utilizados para redução das enchentes.

CRUZ e AGRA (2003) consideram que a implantação de microreservatórios deve ser planejada para evitar o agravamento de situações já críticas e observam problemas referentes aos custos envolvidos na implantação e manutenção do sistema.

Entretanto, PORTO (1998) ressalta que os reservatórios de detenção de pequeno porte vem sendo aos poucos implementado em nosso meio técnico e têm como vantagem a possibilidade de serem implantados de modo a operar essencialmente de forma natural, sem a necessidade da ação humana, através de manobras de comportas ou outros dispositivos de liberação.

MASCARENAS et al (2001) consideram que os reservatórios de detenção podem ser boas soluções para a consecução dos objetivos propostos e ainda integrar o ambiente urbano harmoniosamente. 

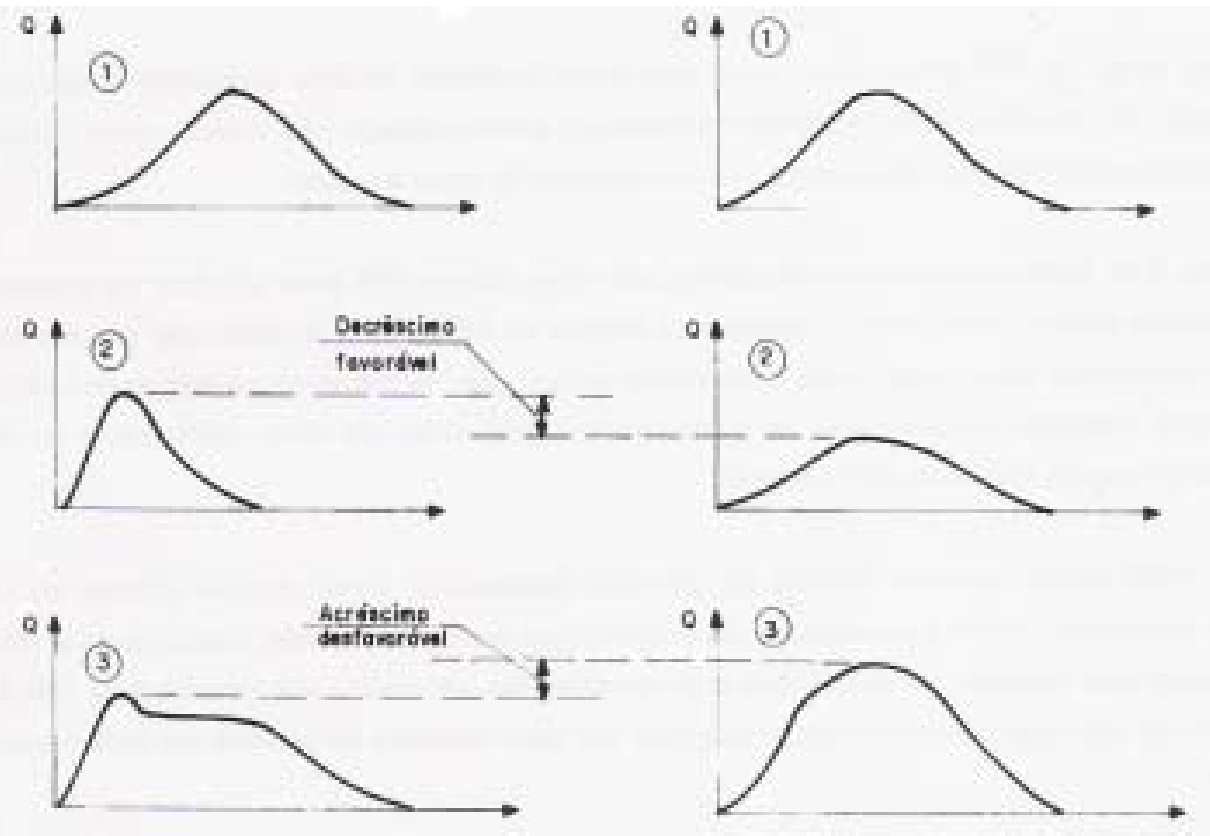

1- condição sem intervenção;

2- condição com intervenção favorável;

3- condição com intervenção desfavorável

Figura 32 - Interação adversa nos hidrogramas de cheias Fonte : PMSP/FCTH (1999)

Nos últimos anos, os reservatórios de detenção vêm sendo difundidos como elementos ambientalmente corretos de controle de cheias urbanas, passando a constar de legislações municipais ou sendo aspirada por aqueles que ainda não efetivaram sua utilização. 


\subsection{Tipos de Reservatórios}

Os reservatórios de detenção podem ser abertos ou fechados, enterrados ou não, dependendo de sua localização, da área disponível e também da legislação existente.

Os reservatórios de grandes dimensões podem ser ainda "em linha", in-line ou in stream, quando implantados nas "próprias margens dos cursos d'água" com enchimento através do transbordamento do leito menor, propiciando hidrogramas abatidos, conforme figura 33, ou com detenção lateral, off-line ou off-stream, quando implantados "nas áreas laterais disponíveis" com enchimento feito através do desvio da água do seu curso normal (figura 34), promovendo corte horizontal no hidrograma, conforme figura 35. Um exemplo de reservatório "em linha" seguido de um reservatório com detenção lateral, implantados no mesmo curso d'água, é apresentado na figura 36.

Os reservatórios de detenção, principalmente os microreservatórios, podem assumir os mais variados formatos e serem constituídos dos mais diversos materiais (concreto, alvenaria, fibrocimento, solo, etc.), sendo essas possibilidades apontadas por TASSI (2002) como seus principais trunfos e motivo de sua popularidade.

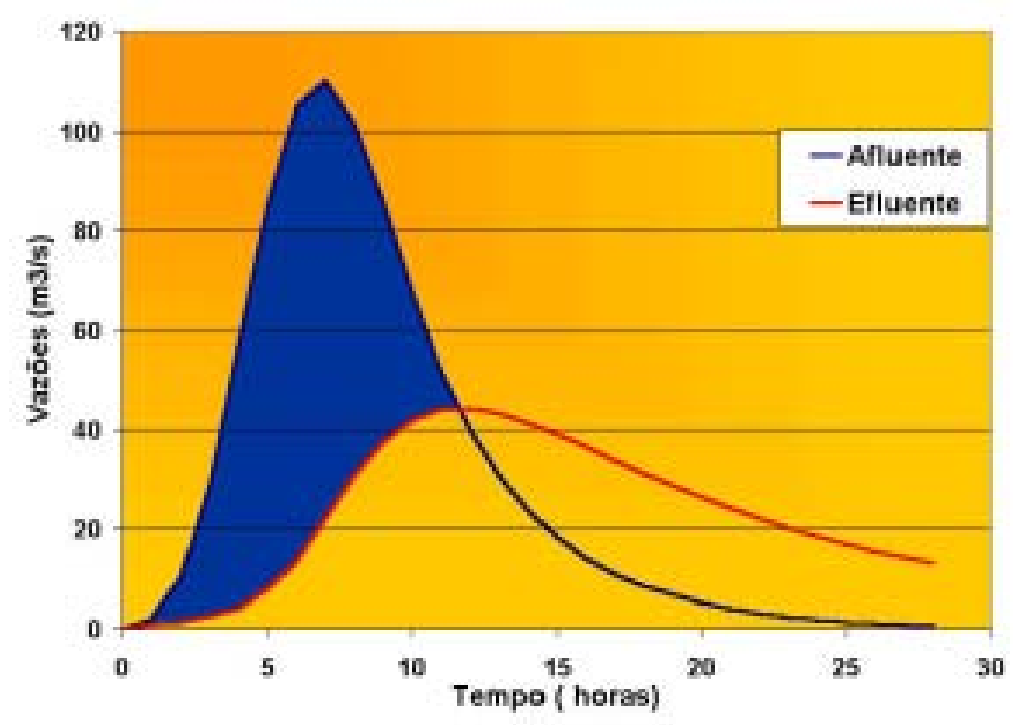

Figura 33 - Hidrograma de reservatório in-line Fonte : Porto e Filho (2004) 


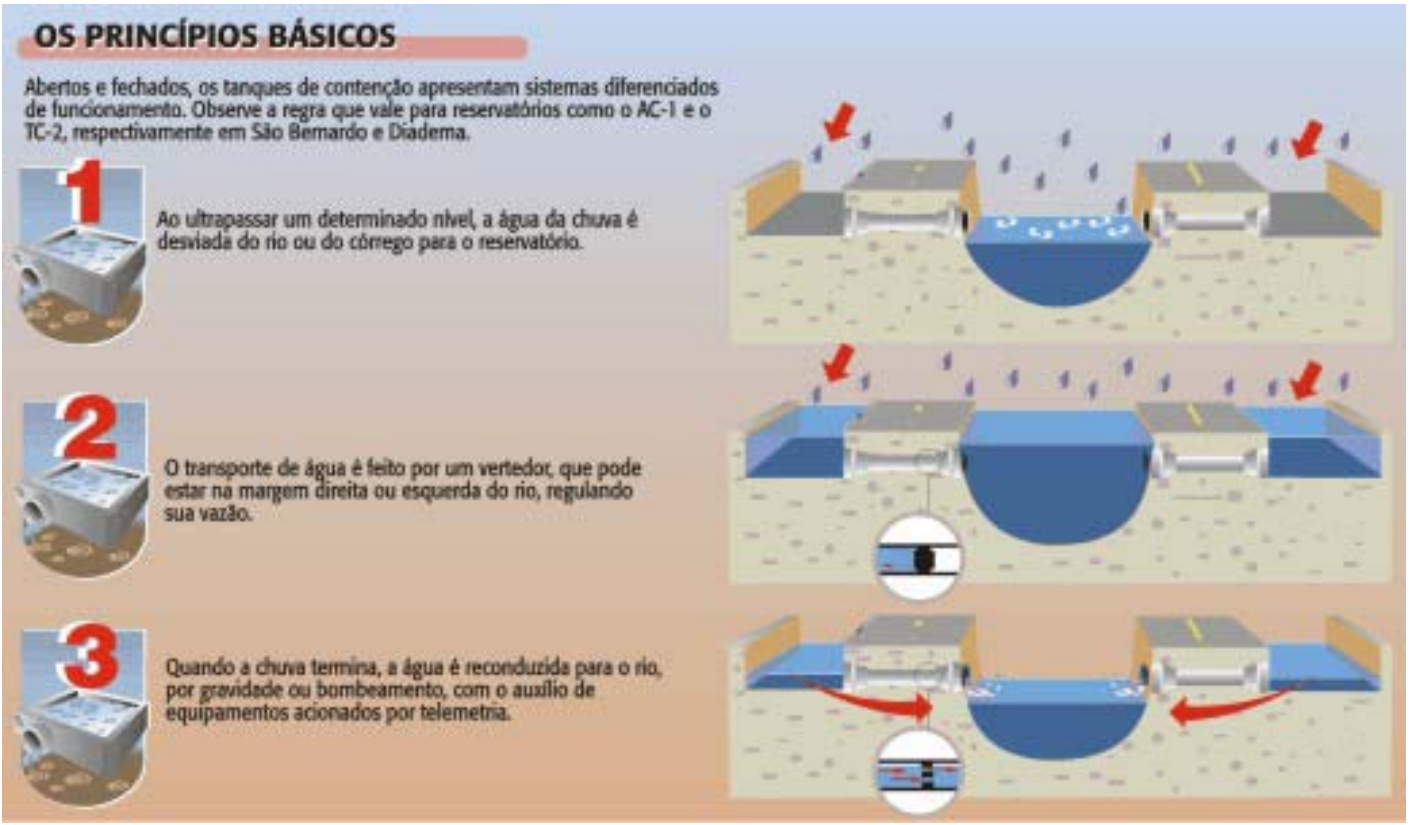

Figura 34 - Princípios básicos de funcionamento do reservatório off-line Fonte : DAEE (1998)

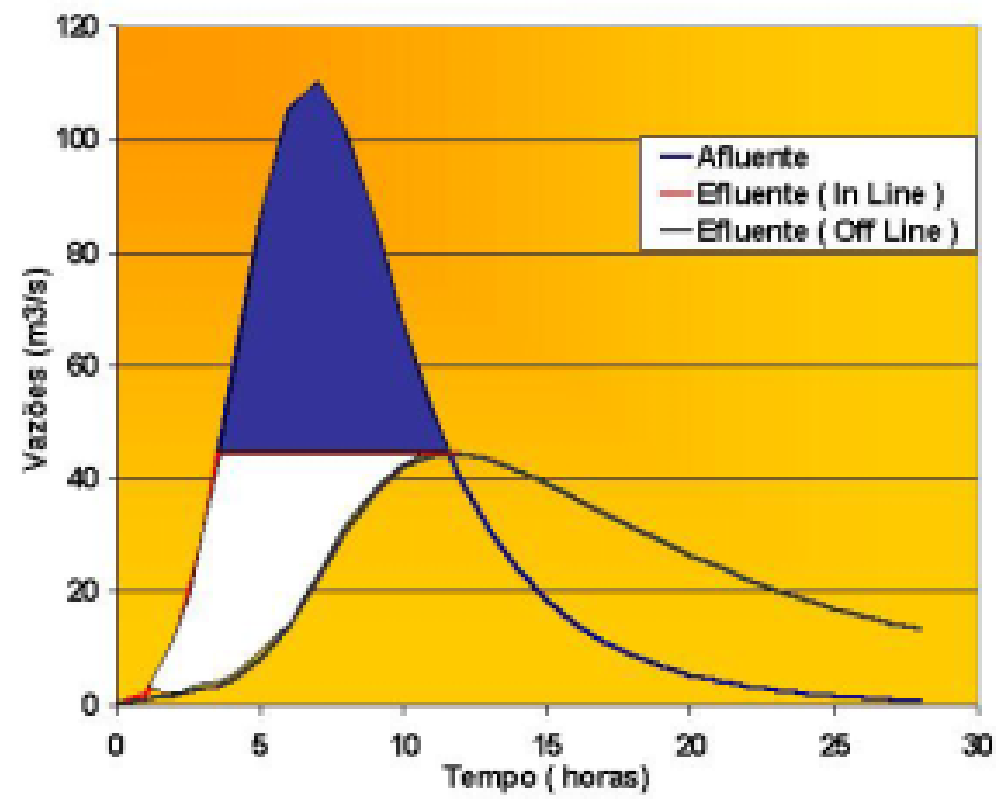

Figura 35 - Hidrograma de reservatório off-line Fonte : Porto e Filho (2004) 


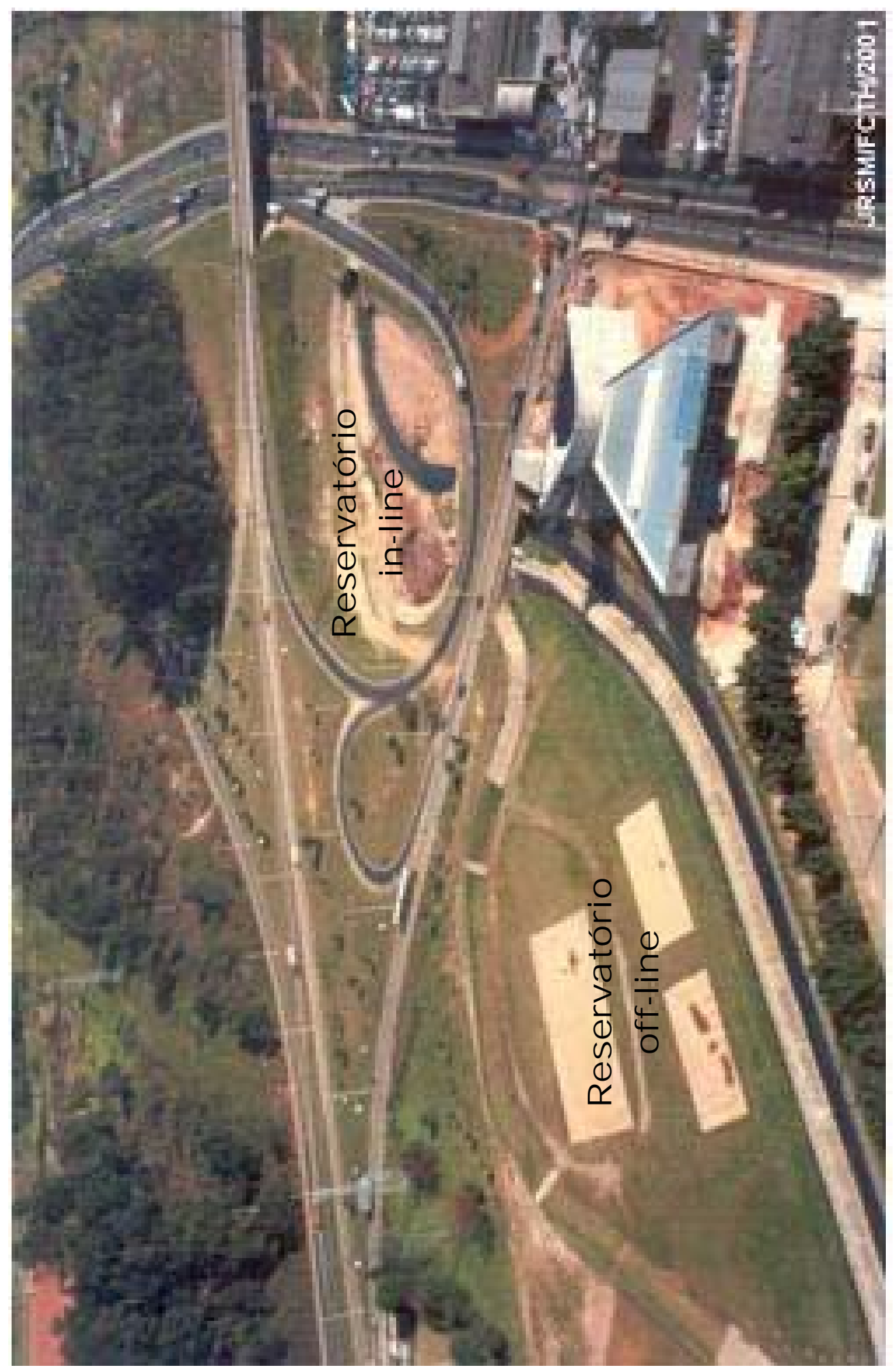

Figura 36 - Reservatório in-line e off-line

Fonte : DAEE (1998a) 


\subsection{Composição Estrutural Básica}

Os reservatórios de detenção são compostos por estrutura de entrada, corpo de armazenamento, estrutura de descarga e dispositivo de extravasão.

As estruturas de entrada podem ser por gravidade, quando encontram-se acima da cota de armazenamento dos reservatórios, ou por bombeamento, em situação inversa. O bombeamento é indicado somente se houver um local privilegiado para sua instalação que compense os gastos decorrentes (PORTO e FILHO, 2004). Especial atenção deve ser dada para o controle do aporte de resíduos sólidos ao interior do reservatório, de forma que a presença de gradeamento ou similares são rotineiras e desejadas.

O corpo de armazenamento é a parte responsável pela contenção dos volumes propriamente ditos e podem ser constituídos dos mais diversos materiais, ou mesmo ser no próprio solo, com a criação ou aproveitamento de uma depressão.

As estruturas de descarga ou saída, similarmente às estruturas de entrada, podem ser por gravidade, condição típica de reservatórios constituídos através de barramento ou com lançamento em contas inferiores à cota de implantação do reservatório; ou por bombeamento, situação comumente encontrada que exige gastos com energia e cuidados especiais de operação e manutenção (PORTO e FILHO, 2004). As estruturas de descarga tem papel fundamental no sistema, pois controlam a vazão de saída, o nível da água no reservatório e o volume retido, sendo elemento gerador de conflito entre as diversas funções para as quais o reservatório pode ser projetado (OLIVEIRA, 2004). São estruturas sujeitas a entupimentos, principalmente no caso dos microreservatórios, onde os diâmetros de saída costumam ser muito pequenos $^{98}$.

Os dispositivos de extravasão são elementos de segurança do sistema contra eventos de magnitudes maiores e podem ou não estar acoplados às estruturas de saída. Para os microreservatórios de detenção que são projetados para pequenos períodos de retorno, os extravasores devem receber atenção especial devido à frequiência de uso.

\footnotetext{
${ }^{98}$ O Conselho Urbano de Minessota - MUC adota como regra geral que reservatórios de detenção devem ser utilizados para áreas superiores a 10 acres (4 ha), puramente em função das características dos dispositivos de saída, que devem ter dimensões suficientes para evitar entupimentos.
} 


\subsection{Dimensionamento}

As mesmas considerações para obtenção de parâmetros de projetos observados para outros tipos de dispositivos de drenagem são observados para os reservatórios de detenção. Assim, informações sobre a bacia de contribuição e suas modificações ao longo do tempo, o período de retorno, os tempos de concentração, as equações de chuva ou outro modelo de transformação de chuva em vazão, os hidrogramas afluentes e efluentes, o dimensionamento hidráulico dos dispositivos, etc. são parâmetros e critérios a serem obtidos, adotados e calculados, porém com o agravante de que para reservatórios de detenção de menor porte, alguns desses itens não possuem consenso no meio técnico e nem estão devidamente esclarecidos nas legislações em vigor, ficando a cargo de cada profissional determinar os caminhos a seguir.

Observa-se aqui que para a grande maioria das situações, existem ferramentas disponíveis, faltando apenas orientações de qual e como usá-las frente a um novo dispositivo de drenagem e suas condições de contorno.

NASCIMENTO, ELLIS e DEUTSCH (1999) observam que o projeto e metodologias tradicionais para dimensionamento de reservatórios de armazenamento são essencialmente baseados nos volumes de contenção necessários para um determinado período de retorno e nas vazões máximas de saída permitidas para atenuação dos volumes de pico do escoamento, conforme a capacidade dos sistemas de drenagem a jusante.

Para determinação do volume dos reservatórios de detenção, existem modelos simplificados e modelos de amortecimento ${ }^{99}$.

Modelos simplificados são utilizados para áreas muito pequenas ou a nível de planejamento, fazendo uso de poucas informações dos hidrogramas de entrada antes da urbanização e após a urbanização, como por exemplo, tempo de pico e/ou concentração. Um exemplo deste modelo é o método de McCuen ${ }^{100}$ apresentado por TUCCI, PORTO e BARROS (1995).

\footnotetext{
${ }^{99}$ Como o presente trabalho não tem a intenção de analisar os métodos de dimensionamento, é apresentada somente uma breve descrição de cada método e algumas referências bibliográficas.

${ }^{100}$ Exemplo numérico no capítulo sobre o controle do impacto da urbanização, no livro Drenagem Urbana, organizado por TUCCI, PORTO e BARROS (1995).
} 
Modelos de amortecimento são utilizados nos demais casos e baseiam-se nos volumes resultantes dos hidrogramas de entrada e saída do reservatório. Nesses modelos a vazão do dispositivo de saída regula o volume a ser armazenado, constituindo-se em elemento de fundamental importância. Segundo TUCCI, PORTO e BARROS (1995), um dos métodos mais utilizados para amortecimento em reservatórios é o método de Pulz ${ }^{101}$, baseado no princípio de conservação de massa entre o armazenamento no reservatório e as vazões de entrada e saída. Neste método, o volume é determinado por tentativas sucessivas, analisando as variações ao longo do tempo para uma certa configuração do sistema.

TUCCI (1997) e WANIELISTA (1990) ressaltam que geralmente, as bacias de detenção não reduzem o volume do escoamento direto, apenas redistribuem as vazões ao longo de um tempo maior, formando um volume útil temporário com parte do escoamento direto e que esse volume corresponde à área compreendida entre os hidrogramas afluente e efluente da bacia" (figura 37).

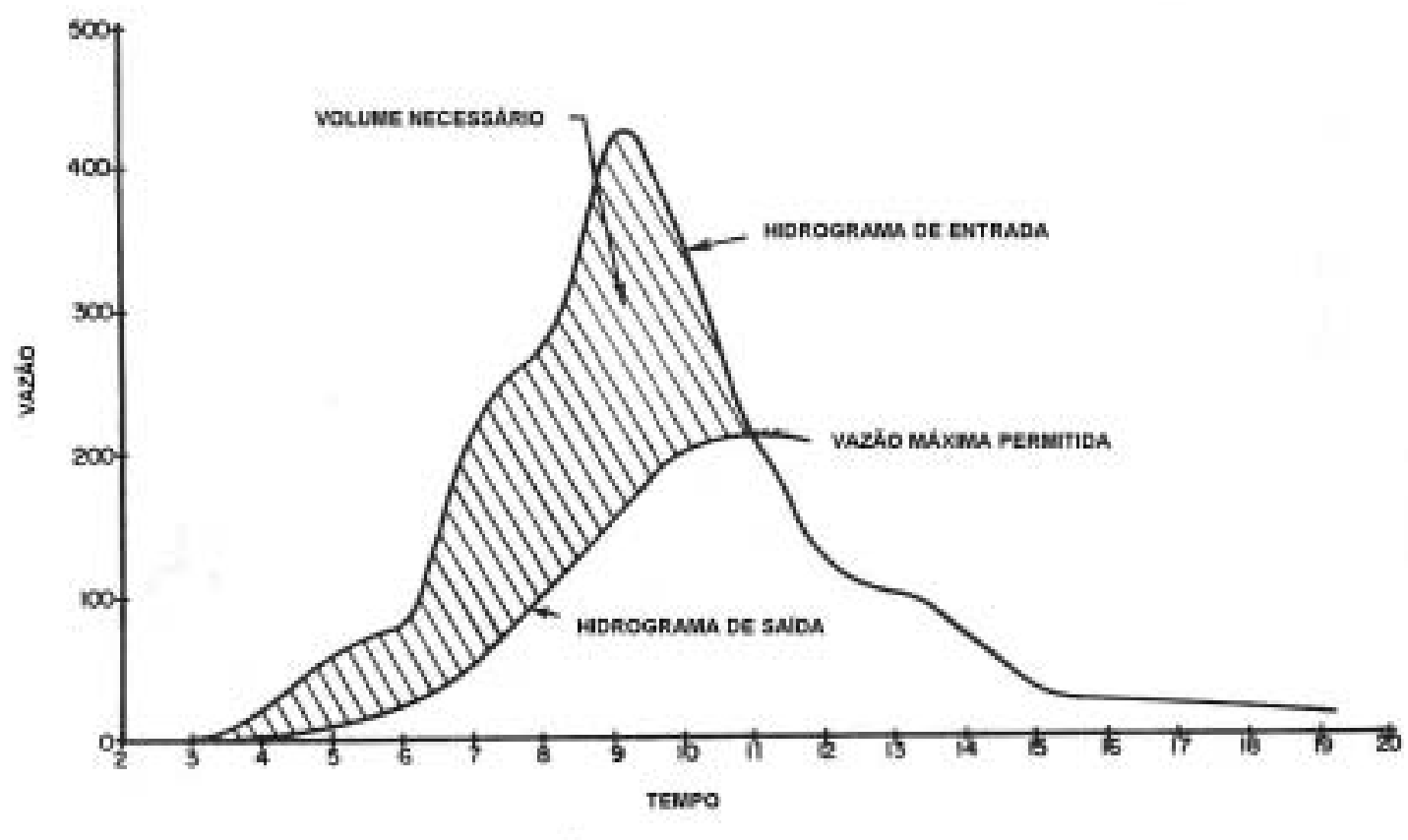

Figura 37 - Volume a ser armazenado pelo reservatório de detenção Fonte : Wanielista (1990)

\footnotetext{
${ }^{101}$ Descrição conceitual e aplicações numéricas encontradas no livro Drenagem Urbana, no capítulo sobre o controle do impacto da urbanização, organizado por TUCCI, PORTO e BARROS (1995) e na
} 
Para CRUZ, ARAÚJO e SOUZA (1999), que elaboraram um estudo sobre o uso das estruturas de controle do escoamento urbano na microdrenagem, o dimensionamento de um microreservatório de detenção de águas pluviais deve assumir o risco adotado para projetos comuns de microdrenagem e trazer consigo a necessidade da redução das vazões de saída para a previsão máxima de ocupação da bacia considerada. Desta forma, aconselham o método de McCuen para dimensionamento destes dispositivos por apresentar boa aproximação com o volume necessário, porém observam que este processo de dimensionamento não considera o comportamento das estruturas de saída, que possuem fundamental importância no sistema, uma vez que determinam a taxa de armazenamento da estrutura e a vazão máxima liberada. Os autores esclarecem que trabalhos anteriores confirmam seu bom desempenho se comparados a outros mecanismos de simulação mais sofisticados, que exigem maior número de informações.

CRUZ e AGRA (2003) apresentando uma comparação entre volumes determinados por métodos diversos para variadas dimensões de lotes, observaram comportamentos diferenciados entre as metodologias utilizadas, conforme pode ser visualizada na tabela $13^{102}$ e figura 38 .

Tabela 13 - Média superior de volume de um método com relação aos demais

\begin{tabular}{|l|c|c|c|c|c|c|}
\hline Área do lote $\left(\mathbf{m}^{\mathbf{2}}\right)$ & $\begin{array}{c}\text { Decreto } \\
\text { POA }\end{array}$ & $\begin{array}{c}\text { Tempo } \\
\text { crítico }\end{array}$ & $\begin{array}{c}\text { Muller- } \\
\text { Neuhaus }\end{array}$ & McCuen & $\begin{array}{c}\text { Método } \\
\text { do corte }\end{array}$ & $\begin{array}{c}\text { Simulado } \\
(\text { Pulz })\end{array}$ \\
\hline Até 600 & $130 \%$ & $67 \%$ & $11 \%$ & $-7 \%$ & $-19 \%$ & $-19 \%$ \\
\hline Entre 600 e 1200 & $99 \%$ & $40 \%$ & $10 \%$ & $-2 \%$ & $-14 \%$ & $-19 \%$ \\
\hline Entre 1200 e 5000 & $75 \%$ & $21 \%$ & $4 \%$ & $5 \%$ & $-7 \%$ & $-15 \%$ \\
\hline Entre 5000 e 10000 & $66 \%$ & $13 \%$ & $-5 \%$ & $12 \%$ & $-3 \%$ & $-12 \%$ \\
\hline
\end{tabular}

(Fonte: Cruz e Agra, 2003)

publicação da ASCE, denominada Stormwater Detention Outlet Control Structures (1985).

${ }_{102} \mathrm{O}$ decreto POA refere-se a formulação adotada pela cidade de Porto Alegre e foi desconsiderada no cálculo das variações da tabela 13 por apresentar diferença considerável em comparação com os demais métodos (atribuída ao fato da formulação utilizar período de retorno de 10 anos). 


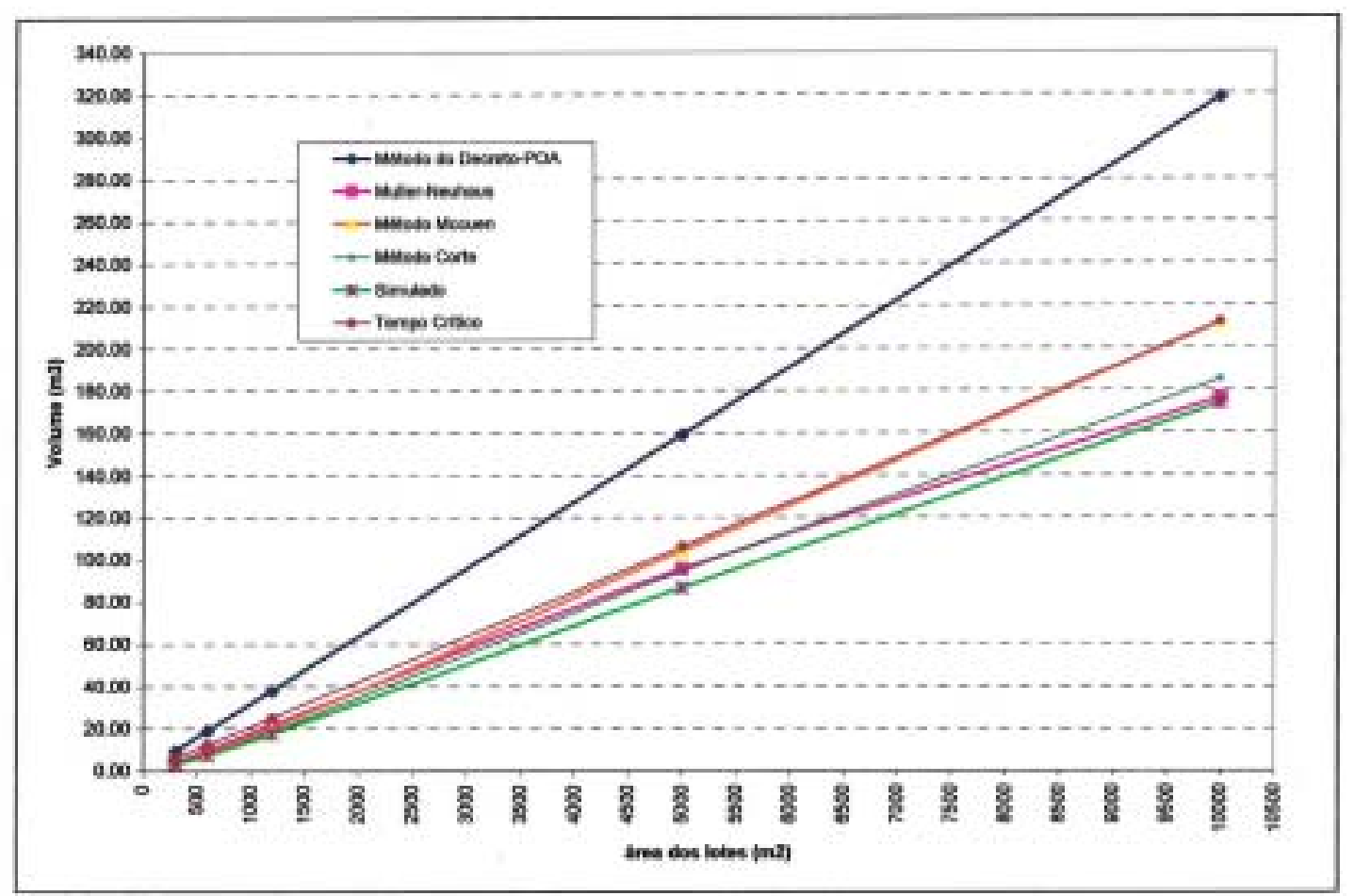

Figura 38 - Comparação entre volumes determinados por metodologias diferentes Fonte : Cruz e Agra (2003)

PARKINSON (site) observa que avanços recentes da tecnologia computacional permitem um melhor entendimento e análise do ciclo hidrológico urbano e auxiliam no desenvolvimento de projetos de sistemas de drenagem, entretanto ressalta que existem problemas inerentes à adoção inadequada de parâmetros e fórmulas matemáticas, associadas à insuficiência de informações, desconsideração das variações dos padrões de distribuição pluviométrica e da diversidade de características da hidrologia local.

PORTO (1998) lembra que embora o problema de dimensionamento dos reservatórios de detenção seja simples, ele envolve uma série de parâmetros que interferem na análise da solução e propõe para estudos preliminares de projeto, a utilização de metodologia adimensional para propiciar tratamento matemático à questão, uma relação funcional simples, pela possibilidade de abordar vários aspectos do mesmo problema com poucos parâmetros. 
WANIELISTA (1990) observa que ainda não há um consenso sobre uma metodologia universalmente aceita pelos projetistas e pelas agências responsáveis pela análise e aprovação de projetos, embora existam procedimentos e práticas convencionais plenamente aceitas pelo meio técnico. Como a geometria e a composição dos dispositivos de saída dos reservatórios estão intimamente ligados e possibilitam as mais variadas combinações, a fixação de um padrão único será trabalhoso. Soma-se a isso, a incisiva influência de peculiaridades locais (legislações, solo, lençol freático, ocupação, população, métodos construtivos, etc. ), além de aspectos hidrológicos (TUCCI e MARQUES, 2001).

\subsection{Vantagens e Desvantagens do Sistema}

Os reservatórios de detenção podem trazer segundo WANIELISTA (1990), TUCCI (1997), PAKINSON et al (2003) e O'LOUGHLIN et al. (1995) citado por CRUZ, ARAÚJO e SOUZA (1999), os seguintes benefícios, dependendo dos propósitos de uso e da forma como foram projetados:

- prevenir impactos adversos do desenvolvimento pela restauração do armazenamento natural perdido;

- diminuir problemas de inundações localizadas;

- reduzir as vazões máximas de inundação à jusante;

- reduzir os custos dos sistemas de drenagem à jusante, através da redução das dimensões do sistema de drenagem;

- controlar problemas de erosão em pequenos tributários através da redução das vazões;

- aumentar o tempo de resposta do escoamento superficial;

- melhorar e criar base para controle da qualidade da água;

- incentivar o reuso e a recarga de aqüíferos;

- melhorar a qualidade paisagística através do aumento de áreas verdes e parques;

- criar oportunidades de recreação à comunidade;

- possibilitar a implantação em áreas públicas, tais como praças, parques e quadras; 
- possibilitar a transferência de responsabilidades e custos do desenvolvimento para aqueles que o promovem e dele se beneficiam;

- atender características locais com regras simples e efetivas desenvolvidas com base em estudos de modelos, como por exemplo, taxas ou volumes de armazenamento por unidade de área.

O’LOUGHLIN et al. (1995) citado por CRUZ, ARAÚJO e SOUZA (1999) enumeraram também as desvantagens dos sistemas de detenção locais:

- sob algumas condições hidrológicas, armazenamentos localizados na parte superior da bacia podem aumentar as taxas de escoamento a jusante, devido a hidrogramas sobrepostos;

- são pouco eficientes na redução de poluentes agregados;

- a manutenção é o problema principal, restando uma grande carga de administração ao poder público e obrigações muito pesadas para os proprietários;

- o sistema pode não ser economicamente eficiente, se comparados com soluções mais centralizadas.

Os reservatórios de detenção permitem também que o lixo produzido permaneça no seu ponto de origem, melhorando as condições de jusante e obrigando o produtor dos resíduos a se responsabilizar por eles ${ }^{103}$ (CANHOLI, 2002). Entretanto, apesar do aspecto positivo do produtor se responsabilizar pelo produto, a questão básica do lixo está no funcionamento inadequado do sistema por obstruções e a proliferação de vetores prejudiciais à saúde por falta ou deficiência de limpezas periódicas.

A adoção de reservatórios de detenção requer também a utilização concomitante de medidas não-estruturais, especialmente de educação ambiental, pois seu funcionamento está intimamente relacionado com o comportamento e hábitos da

\footnotetext{
${ }^{103}$ Sem esses dispositivos, o que se via era o constante acúmulo do lixo nas partes mais planas, de menor velocidade, muitas vezes locais distantes do ponto de origem do mesmo.
} 
população da bacia de contribuição, em particular da forma de disposição dos resíduos sólidos e de intervenção no desenvolvimento local (uso e ocupação do solo).

Acrescenta-se ainda a necessidade de fiscalização e a possibilidade de rejeição por parte da população.

\subsection{Estudos e Experiências ${ }^{104}$}

CUNDOM e GUTIERREZ (2001) analisando os fenômenos da urbanização e seus efeitos sobre os problemas de inundações, através da simulação da evolução temporal do desenvolvimento de um bairro residencial com pequena bacia hidrográfica, concluíram que a avaliação das medidas mitigadoras passíveis de serem implantadas requerem em primeira instância a definição do estado atual da bacia, pois a eficiência e a relação custo-benefício será função direta deste estado e das decorrências associadas à sua implantação, além de que para uma bacia urbanizada, as medidas de maior eficiência e maior facilidade de implantação são as medidas estruturais descentralizadas em lotes.

Foi observado também que o efeito da urbanização sobre o comportamento hídrico da bacia se intensifica para eventos de magnitudes baixas, onde para as condições de pré-urbanização, a detenção superficial, a infiltração, a evaporação e os efeitos da evapotranspiração pesam consideravelmente sobre o balanço hidrológico. Para eventos de magnitudes maiores, ou seja, com períodos de retorno elevado, a sensibilidade da bacia ao processo de urbanização diminui porque há uma rápida saturação do solo e este passa a não mais interferir no escoamento superficial.

SPIRN (1995) informa que nas últimas décadas foi possível presenciar uma profusão de abordagens inovadoras e significativas do controle das enchentes em cidades norte-americanas, onde telhados, praças, estacionamentos e parques foram projetados para armazenar as águas das chuvas, e bosques e várzeas nas cabeceiras foram preservados por sua capacidade natural de armazenamento das águas, significando apenas pequeno ou nenhum aumento extra de custos de construção,

\footnotetext{
104 Os estudos apresentados estão voltados para os reservatórios de detenção de pequeno porte implantados em lotes ou loteamentos, por ser esta a situação que mais se aproxima das implantações feitas pela CDHU e apresentados nos estudos de casos.
} 
inconveniências mínimas e conquista de novas áreas de lazer. A autora observa também que freqüentemente, essas áreas fornecem o único espaço disponível para retenção de águas pluviais em áreas densamente urbanizadas.

CRUZ, TUCCI e SILVEIRA (2000) utilizando lotes hipotéticos ${ }^{105}$ avaliaram os efeitos de diferentes taxas de impermeabilização sobre os hidrogramas de saída, as estruturas de descarga e o custo dos reservatórios.

Os resultados da simulação do impacto da urbanização mostram aumento nos picos de vazão da ordem de 17 a $45 \%$ e aumento de volume de 39 a $109 \%$ em relação aos valores de pré-ocupação, conforme visualizado nas figuras 39 e 40 .

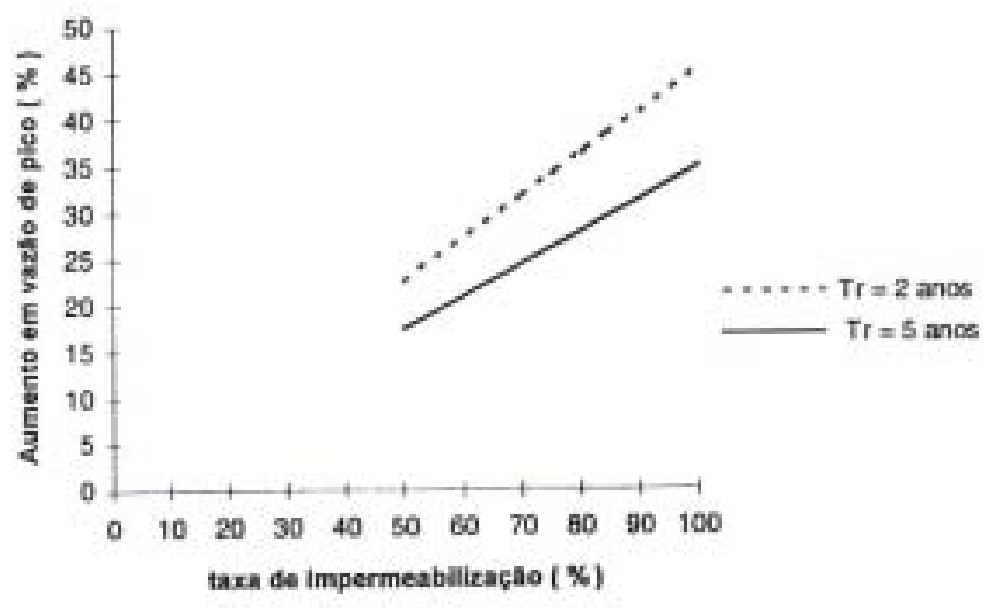

Figura 39 - Aumento da vazão de pico em função da impermeabilização Fonte : Cruz, Tucci e Silveira (2000)

\footnotetext{
105 com áreas variando de 300 a $600 \mathrm{~m}^{2}$, declividade de $4 \%$, período de retorno entre 2 e 5 anos e precipitações com duração de 25 minutos
} 


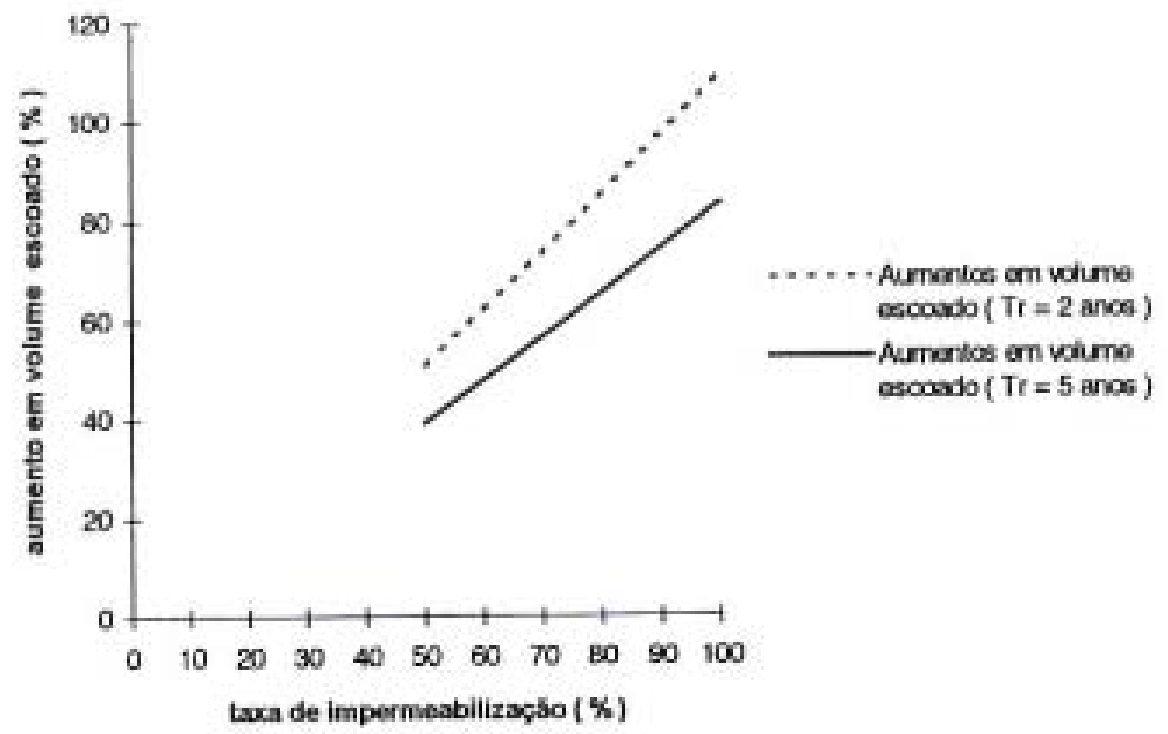

Figura 40 - Aumento do volume escoado em função da impermeabilização Fonte : Cruz, Tucci e Silveira (2000)

Para avaliação das estruturas de saída, foram projetados 6 tipos diferentes de reservatório $^{106}$ com descarregador de fundo constituído de tubos de PVC em diâmetros comerciais de acordo com a necessidade, e vertedor com comprimento constante de $1 \mathrm{~m}$, conforme figuras 41 e 42 .

Os volumes de amortecimento para o lote de $600 \mathrm{~m}^{2}$ totalmente impermeabilizado, ficaram entre 2 e $2,5 \mathrm{~m}^{3}$, dependendo do tipo de estrutura, e a área ocupada em planta em relação à área total do lote não ultrapassou $1 \%$. A título de ilustração apresenta-se os resultados das simulações para o reservatório lacrado com $1 \mathrm{~m}$ de profundidade e para o reservatório de $1 \mathrm{~m}$ de profundidade com infiltração em solo batido, respectivamente tabelas 14 e 15, implantados em lote de $600 \mathrm{~m}^{2}$, com período de retorno de 5 anos.

\footnotetext{
${ }^{106}$ Reservatório lacrado com $1 \mathrm{~m}$ de profundidade, reservatório lacrado com $0,40 \mathrm{~m}$ de profundidade, reservatório cilíndrico com $0,60 \mathrm{~m}$ de diâmetro, reservatório aberto gramado, reservatório de $1 \mathrm{~m}$ de profundidade com infiltração em solo batido e reservatório de $0,40 \mathrm{~m}$ de profundidade com infiltração em solo batido.
} 

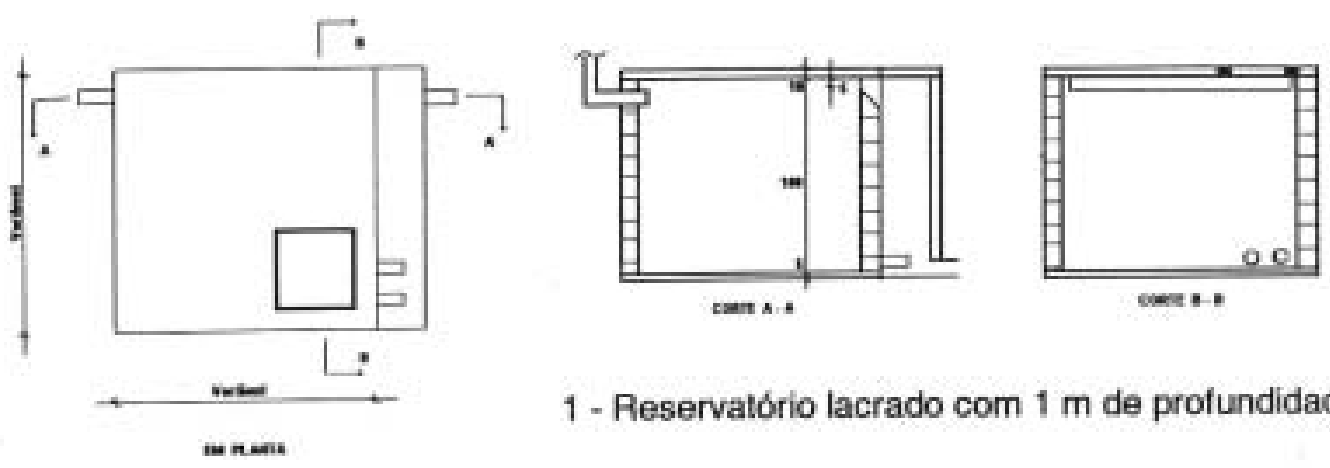

1 - Reservatório lacrado com $1 \mathrm{~m}$ de profundidade

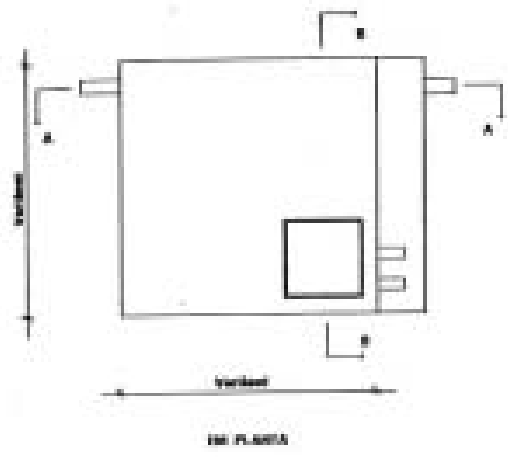

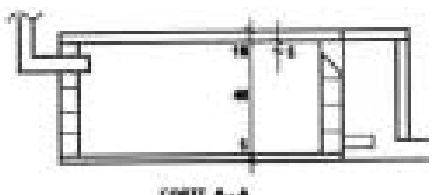

ceen A.A

2 - Reservatório lacrado com $0,40 \mathrm{~m}$ de profundidade

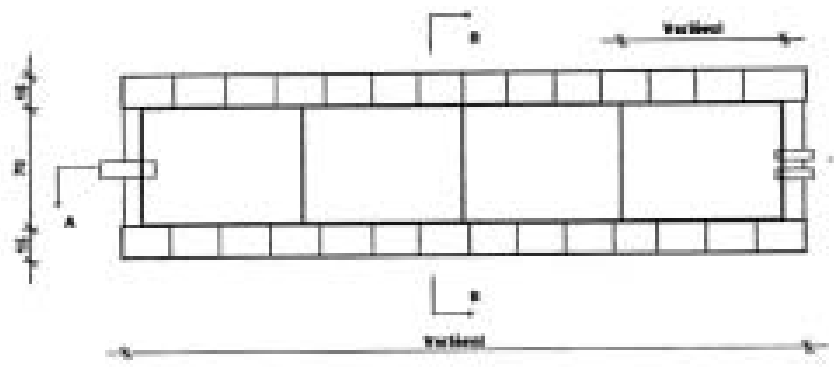

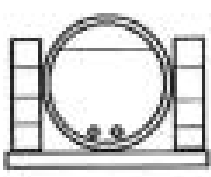

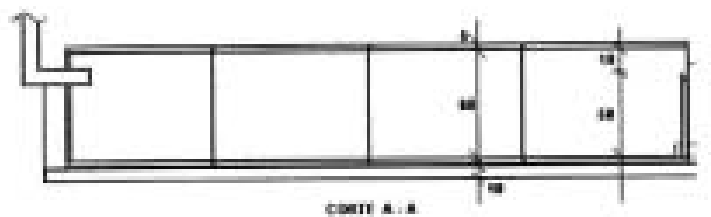

3 - Reservatório cilíndrico com 0,60 m de diámetro

Figura 41 - Esquema construtivos dos reservatórios

Fonte : Cruz, Tucci e Silveira (2000) 

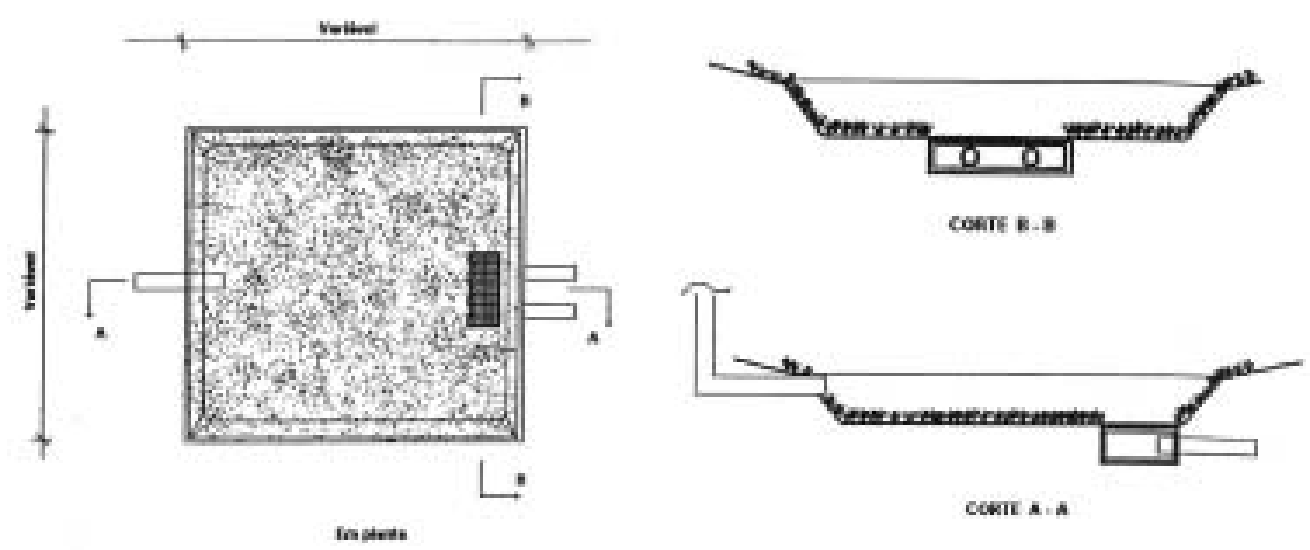

4 - Reservatório aberto gramado
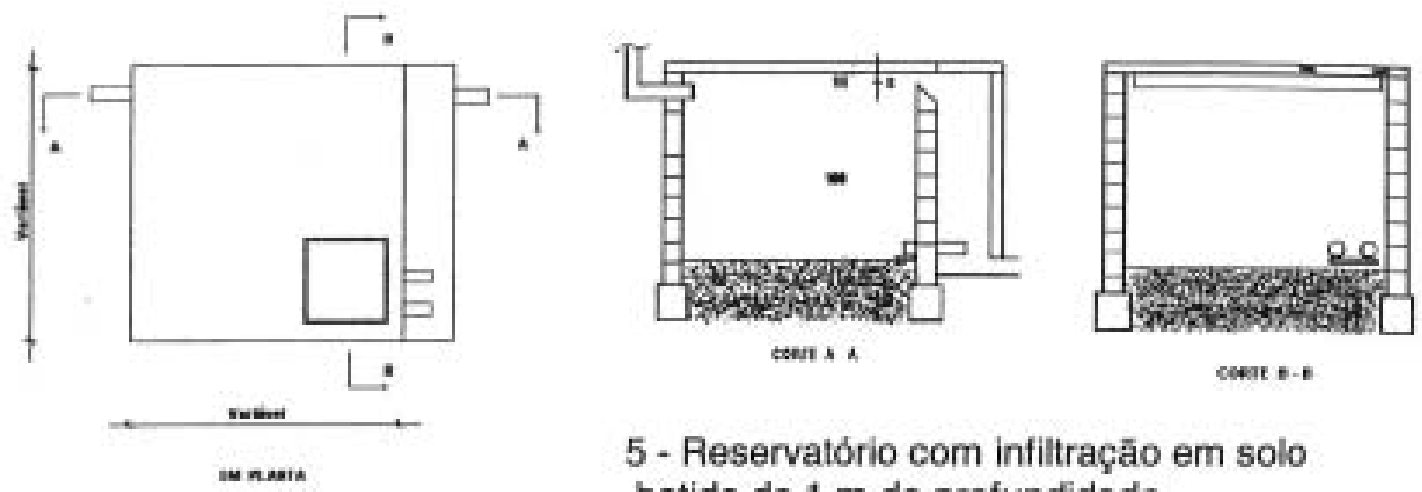

ceeat S-E

5 - Reservatório com infiltração em solo batido de $1 \mathrm{~m}$ de profundidade
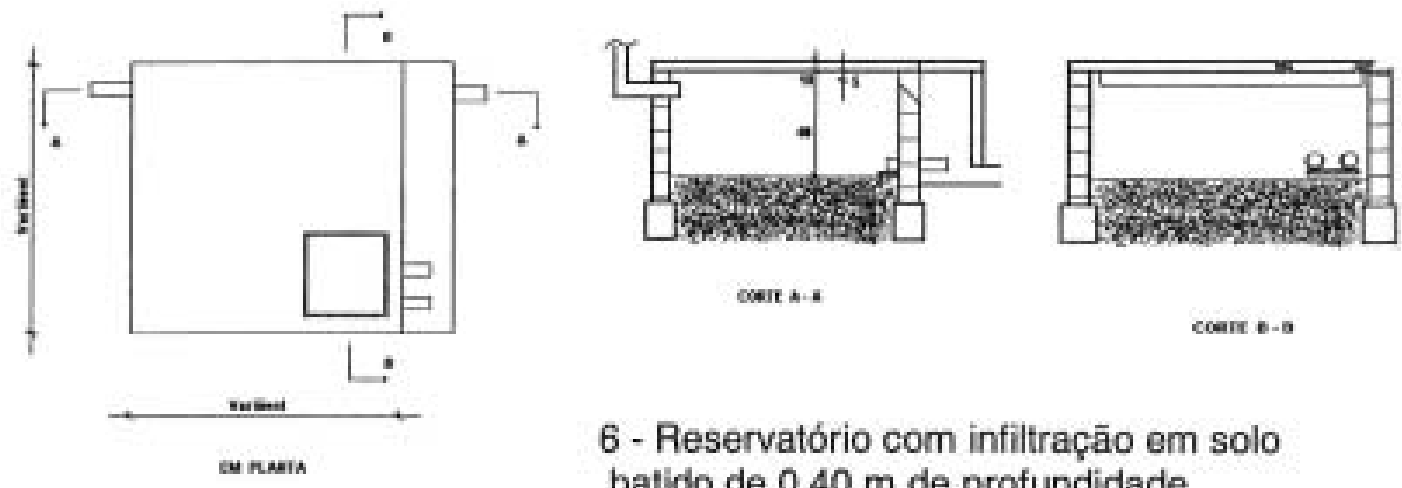

ceare e-a

6 - Reservatório com infiltração em solo batido de $0,40 \mathrm{~m}$ de profundidade

Figura 42 - Esquema construtivos dos reservatórios 1

Fonte : Cruz, Tucci e Silveira (2000) 
Tabela 14 - Reservatório lacrado com $1 \mathrm{~m}$ de profundidade

\begin{tabular}{|c|c|c|c|c|c|}
\hline $\begin{array}{c}\text { Taxa de } \\
\text { impermeabilização }\end{array}$ & $\begin{array}{c}\text { Vazão } \\
\text { sem } \\
\text { detenção } \\
(\mathbf{I} / \mathbf{s})\end{array}$ & $\begin{array}{c}\text { Volume do } \\
\text { reservatório } \\
\left(\mathbf{m}^{\mathbf{3}}\right)\end{array}$ & $\begin{array}{c}\text { Quantidade } \\
\text { e diâmetro } \\
\text { dos tubos }\end{array}$ & $\begin{array}{c}\text { Vazão } \\
\text { com } \\
\text { detenção } \\
(\mathbf{l} / \mathbf{s})\end{array}$ & $\begin{array}{c}\text { Tempo } \\
\text { de } \\
\text { detenção } \\
(\mathbf{m i n} .)\end{array}$ \\
\hline 0 & 9,0 & - & - & - & - \\
\hline 50 & 10,6 & 1,5 & $1 \mathrm{D} 60$ & 7,2 & 16 \\
\hline 75 & 11,4 & 2,0 & $1 \mathrm{D} 60$ & 7,1 & 24 \\
\hline 80 & 11,5 & 2,0 & $1 \mathrm{D} 60$ & 7,2 & 24 \\
\hline 90 & 11,8 & 2,0 & $1 \mathrm{D} 60$ & 7,4 & 30 \\
\hline 100 & 12,2 & 2,5 & $1 \mathrm{D} 60$ & 7,0 & 32 \\
\hline
\end{tabular}

(Fonte: Cruz, Tucci e Silveira, 2000)

Tabela 15 - Reservatório de $1 \mathrm{~m}$ de profundidade com infiltração em solo batido

\begin{tabular}{|c|c|c|c|c|c|}
\hline $\begin{array}{c}\text { Taxa de } \\
\text { impermeabilização }\end{array}$ & $\begin{array}{c}\text { Vazão } \\
\text { sem } \\
\text { detenção } \\
(\mathbf{l} / \mathbf{s})\end{array}$ & $\begin{array}{c}\text { Volume do } \\
\text { reservatório } \\
\left(\mathbf{m}^{\mathbf{3}}\right)\end{array}$ & $\begin{array}{c}\text { Quantidade } \\
\text { e diâmetro } \\
\text { dos tubos }\end{array}$ & $\begin{array}{c}\text { Vazão } \\
\text { com } \\
\text { detenção } \\
(\mathbf{l} / \mathbf{s})\end{array}$ & $\begin{array}{c}\text { Tempo } \\
\text { de } \\
\text { detenção } \\
(\mathbf{m i n} .)\end{array}$ \\
\hline 0 & 9,0 & - & - & - & - \\
\hline 50 & 10,6 & 1,5 & $1 \mathrm{D} 60$ & 7,2 & 22 \\
\hline 75 & 11,4 & 1,5 & $2 \mathrm{D} 40$ & 8,1 & 27 \\
\hline 80 & 11,5 & 2,0 & $1 \mathrm{D} 60$ & 7,2 & 28 \\
\hline 90 & 11,8 & 2,0 & $1 \mathrm{D} 60$ & 7,4 & 38 \\
\hline 100 & 12,2 & 2,5 & $1 \mathrm{D} 60$ & 7,0 & 22 \\
\hline
\end{tabular}

(Fonte: Cruz, Tucci e Silveira, 2000) 
O custo total de implantação dos diferentes tipos de reservatórios de 2,0 e 2,5 $\mathrm{m}^{3}$ podem ser apreciados na tabela 16, onde observa-se que os reservatórios subterrâneos ficaram em média entre US\$ 400 e US\$ 500, representando um custo 3 a 4 vezes superior ao do reservatório aberto e gramado, porém os custos de manutenção deste último pode levá-lo a atingir o custo das demais estruturas em 4 ou 5 anos.

Tabela 16 - Custo de implantação dos reservatórios de 2,0 e 2,5 m³

\begin{tabular}{|l|c|c|}
\hline Tipo de reservatório & $\begin{array}{c}\text { Volume } \\
\left(\mathbf{m}^{3}\right)\end{array}$ & $\begin{array}{c}\text { Custo total } \\
(\mathbf{U S} \$ \mathbf{)}\end{array}$ \\
\hline Reservatório lacrado de 1 m de profundidade & 2,0 & 450,69 \\
\cline { 2 - 3 } & 2,5 & 522,65 \\
\hline Reservatório lacrado de 0,40 m de profundidade & 2,0 & 531,33 \\
\cline { 2 - 3 } & 2,5 & 614,55 \\
\hline Reservatório cilíndrico de 0,60 m de diâmetro & 2,0 & 551,55 \\
\cline { 2 - 3 } & 2,5 & 686,44 \\
\hline Reservatório gramado e aberto & 2,0 & 139,51 \\
\cline { 2 - 3 } & 2,5 & 166,96 \\
\hline Reservatório de 1 m de profundidade em solo batido & 2,0 & 409,62 \\
\cline { 2 - 3 } & 2,5 & 472,66 \\
\hline Reservatório de 0,40 m de profundidade em solo & 2,0 & 442,87 \\
\cline { 2 - 3 } batido & 2,5 & 506,86 \\
\hline
\end{tabular}

(Fonte: Cruz, Tucci e Silveira, 2000)

CRUZ, TUCCI e SILVEIRA (2000) finalizam esclarecendo que a escolha entre um ou outro dispositivo de controle depende também do conhecimento das condições peculiares de cada lote urbano, como aspectos legais de ocupação, tipo de solo, profundidade do lençol freático, profundidade da rede coletora e recursos financeiros disponíveis. 
CRUZ, ARAÚJO e SOUZA (1999) analisando os usos dos dispositivos de controle alternativo do escoamento urbano na microdrenagem, observaram que a eficiência dos microreservatórios de detenção tem se mostrado alta na redução de vazões máximas e na melhoria da qualidade do efluente pluvial, apesar de estarem sujeitos a algumas restrições, como disponibilidade de espaços livres, profundidade da rede coletora, declividade dos lotes, nível do lençol freático, etc.. A figura 43 por eles apresentada é baseada em trabalho feito por CRUZ (1998) e demonstram os volumes estimados para um lote de $600 \mathrm{~m}^{2}$, com diferentes níveis de impermeabilização e período de retorno de 5 anos.

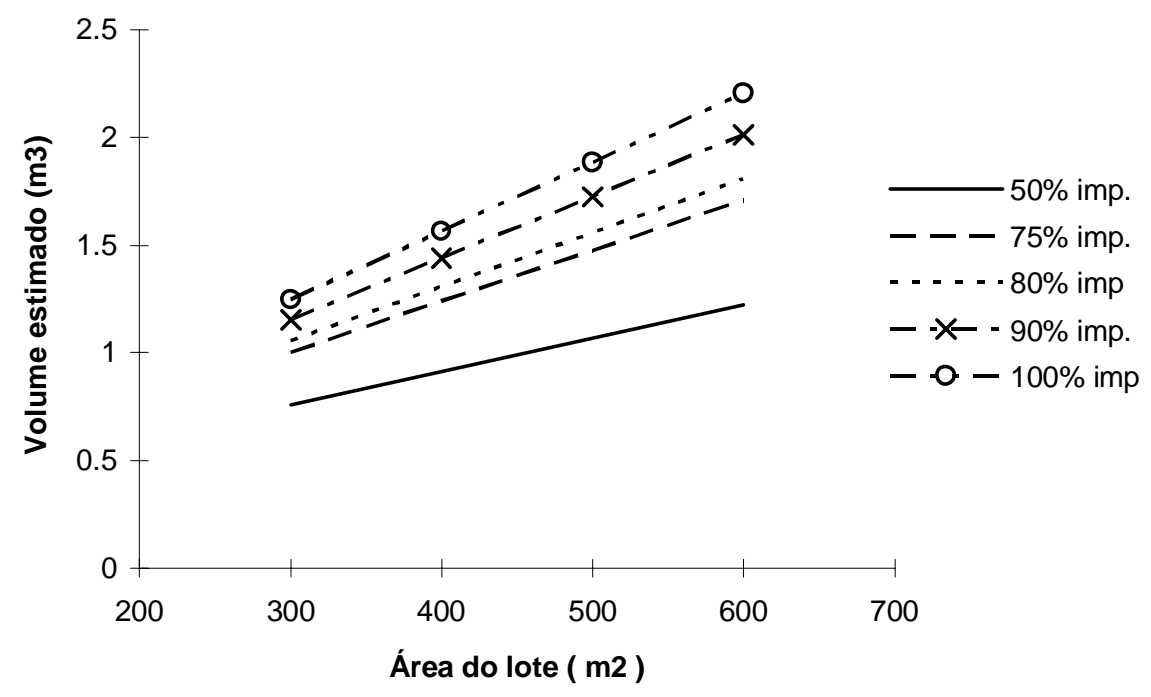

Figura 43 - Volumes de detenção necessários para lotes em Porto Alegre, com diferentes taxas de impermeabilização e TR de 5 anos Fonte : Cruz, Araújo e Souza (1999)

Os custos de implantação dos microreservatórios de detenção no mesmo lote, acima mencionado, com volume de armazenamento entre 2,0 e 2,5 $\mathrm{m}^{3}, 1 \mathrm{~m}$ de profundidade e diferentes tipos de estruturas de armazenamento podem ser apreciadas na figura 44. CRUZ, ARAÚJO e SOUZA (1999) observam que apesar do 
reservatório a céu aberto ser mais econômico do que os subterrâneos, estes necessitam de limpezas mais freqüentes devido a questões de saúde pública.

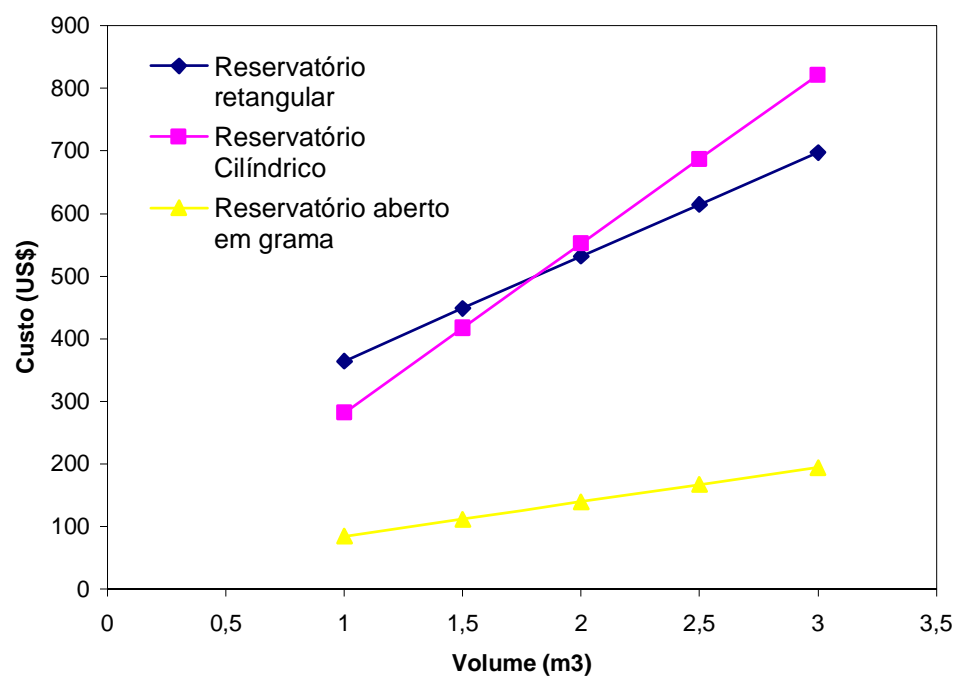

Figura 44 - Custos de implantação de dispositivos de detenção em lotes Fonte: Cruz, Araújo e Souza (1999)

TASSI (2002), estudando o efeito dos microreservatórios de lote sobre a macrodrenagem urbana, através da montagem de uma bacia hipotética, chegou às seguintes conclusões:

- níveis de eficiência da bacia para diversas combinações de TRs e vazões de descarga, variam de 50 a 70\%, de acordo com a vazão na saída dos lotes;

- basicamente o mesmo grau de eficiência obtido ao controlar a vazão de préurbanização, pode ser alcançada ao fixar em até 3 vezes a vazão de préurbanização na saída do lote;

- a possibilidade de aumentar as vazões de saída dos lotes e, conseqüentemente o diâmetro do dispositivo de saída, constitui-se numa vantagem sobre as vazões 
menores que resultam em diâmetros muito pequenos e possivelmente inviáveis em situações reais;

- o custo da implantação conjunta de microreservatórios e redes de drenagem podem, em alguns casos, ser maior do que o custo de implantação simples de redes, sem microreservatórios;

- vazões de restrição da ordem de 3 a 5 vezes a vazão de pré-urbanização levam a redução da diferença de custos observada no item anterior;

- havendo capacidade na rede coletora, a alternativa mais adequada parece ser à utilização da vazão de restrição em torno de 3 vezes a vazão de pré-urbanização.

Para a legislação do Reino Unido, a função primária de qualquer reservatório de armazenamento é o controle de cheias e por esta razão, o detalhamento de projeto e os critérios de operação devem atender totalmente essa finalidade. Além dessa função hidrológica principal, está se tornando obrigatória uma avaliação dos impactos ambientais e a consideração de funções qualitativas (NASCIMENTO, ELLIS e DEUTSCH, 1999). A tabela 17 identifica os principais critérios de projeto associados com o desenvolvimento de cenários de armazenamento de cheias urbanas.

NASCIMENTO, ELLIS e DEUTSCH (1999) comentam que na França, o uso dos reservatórios de detenção vem dos anos 60, junto com a construção das chamadas "Villes Nouvelles". Inicialmente eles foram concebidos com conceitos hidráulicos para controle de cheias a jusante, mas experiências obtidas com seu uso criaram grande necessidade de integração com o contexto urbano e de desenvolvimento de propósitos multifuncionais como a incorporação de áreas de lazer, parques, etc, além da percepção de que os reservatórios poderiam ser utilizados também para controle de qualidade da água (VALIRON et al, 1985 apud NASCIMENTO, ELLIS e DEUTSCH, 1999). 
Tabela 17 - Critérios de projeto para armazenamento de cheias urbanas

\begin{tabular}{|c|c|c|c|}
\hline Critério & \multicolumn{3}{|c|}{ Discriminação } \\
\hline \multirow[t]{8}{*}{ Funcional } & \multirow[t]{4}{*}{ Primário } & \multirow[t]{2}{*}{ Hidrológico } & Vazão de pico e descarga \\
\hline & & & Forma do hidrograma \\
\hline & & \multirow[t]{2}{*}{ Hidráulico } & Curva cota-volume \\
\hline & & & $\begin{array}{l}\text { Adequação das estruturas de } \\
\text { controle }\end{array}$ \\
\hline & \multirow[t]{4}{*}{ Secundário } & \multicolumn{2}{|c|}{ Projeto da área de armazenamento } \\
\hline & & \multicolumn{2}{|c|}{ Comprimento, profundidade, formato } \\
\hline & & \multicolumn{2}{|c|}{ Controle de sedimentação } \\
\hline & & \multicolumn{2}{|c|}{$\begin{array}{l}\text { Acesso para a água, estacionamento, lazer, } \\
\text { etc. }\end{array}$} \\
\hline Ambiental & \multicolumn{3}{|c|}{ Qualidade da água, habitat e ecologia, lazer, aparência, etc. } \\
\hline Construtivo & \multicolumn{3}{|c|}{$\begin{array}{l}\text { Taludamento, terraplenagem, acesso local, estruturas de } \\
\text { proteção, etc. }\end{array}$} \\
\hline Operacional & \multicolumn{3}{|c|}{ Manutenção, inspeção, remoção de sedimentos e lixo, etc. } \\
\hline Legislação & \multicolumn{3}{|c|}{$\begin{array}{l}\text { Acordo e regulamentações sobre lançamentos e qualidade, } \\
\text { limites, etc. }\end{array}$} \\
\hline
\end{tabular}

(Fonte: Nascimento, Ellis e Deutsch, 1999)

PIEL, PEREZ e MAYTRAUD (1999) relatam que em Seine Saint-Denis, na região metropolitana de Paris, foi feito um estudo abrangendo 200 instalações de armazenamento durante um período de 20 anos e as seguintes conclusões foram obtidas desse estudo:

- A performance das instalações de armazenamento é geralmente insuficiente e tende a se deteriorar ao longo do tempo, especialmente para instalações cobertas. Na grande maioria dos casos, a causa apontada foi a falta de manutenção adequada devido à dificuldade de acesso (aberturas obstruídas, necessidade de equipamento especial) ou o esquecimento das instalações depois de muitas mudanças de proprietários ou de responsáveis pelo local; 
- O custo médio das instalações é alto. Normalmente são utilizadas técnicas mais elaboradas de gerenciamento de águas pluviais, resultando em custos significativamente mais altos. Instalações cobertas são as mais caras com custo médio de US\$ $500 / \mathrm{m}^{3}$, podendo chegar a US\$ $1500 / \mathrm{m}^{3}$;

- A integração dos dispositivos à paisagem urbana foi considerada secundária mesmo quando resultam em economia a longo prazo. Instalações abertas tornaram-se raras devido ao alto custo do terreno e são freqüentemente escondidas em áreas remotas, sendo negligenciadas pelos administradores. Instalações com usos múltiplos (estacionamentos, áreas esportivas e áreas de recreação em escolas) são melhores integradas à paisagem urbana e como são utilizadas regularmente também são beneficiadas com uma melhor conservação.

As observações mostram que planejadores frente a restrições de desenvolvimento em áreas densamente urbanizadas usam técnicas que a principio podem parecer satisfatórias, principalmente em termos de uso e implantação, mas que provam ser de uso limitado ou perigoso a médio prazo (PIEL, PEREZ e MAYTRAUD, 1999).

OLIVEIRA (2004) procurou estabelecer critérios e parâmetros de projeto para reservatórios de detenção e retenção, a fim de que essa estruturas também propiciassem melhoria na qualidade das águas, pois acredita-se que elas podem e devem não somente amortecer o hidrograma de cheia, mas também melhorar a qualidade. Para atendimento desta dupla função, é necessário incorporar critérios específicos no dimensionamento dos reservatórios, o que pode gerar conflitos considerando que o favorecimento de uma finalidade geralmente prejudica a outra ${ }^{107}$.

O Conselho Urbano de Minnesota - MUC (2001) indica que um substancial incremento pode ser alcançado na remoção de poluentes, se for possível reter o volume armazenado por 48 horas, porém reconhece que esta solução é difícil para pequenas bacias pela dimensão reduzida que seus dispositivos de saída deveriam ter;

\footnotetext{
${ }^{107}$ Exemplificando, vazões de saída muito pequenas eliminam completamente as ondas de cheia, necessitando de reservatórios grandes e de alto custo com tempo de descarga maior, favorecendo aspectos de qualidade da água e prejudicando a possibilidade de em curto espaço de tempo absorver outra onda de cheia.
} 
ao mesmo tempo confirma o grande potencial desta medida para áreas maiores, especialmente se aliada a métodos de infiltração.

Segundo OLIVEIRA (2004), o sucesso no planejamento de estruturas de armazenamento depende da compreensão dos sistemas de drenagem existentes, dos objetivos a serem alcançados e dos critérios de projetos que podem ser adotados, sendo essencial a definição do papel principal a ser desempenhado pelos reservatórios, pois este determina a escolha dos demais critérios.

NASCIMENTO, ELLIS e DEUTSCH (1999) fazendo uma análise das experiências práticas das soluções de armazenamento, observaram que a apreciação das causas e conseqüências do desenvolvimento urbano, principalmente em termos de qualidade da água e impactos ambientais, mostram um cenário de considerável complexibilidade que podem levar à imposição de limites na utilização de reservatórios de armazenamento, ou outras soluções alternativas, podendo direcionar para o descrédito ou o abandono dessas soluções.

A tabela 18 elaborada pela ASCE - American Society of Civil Engineers (1982) mostra a porcentagem de respostas positivas a um questionário ${ }^{108}$ sobre práticas usuais, opiniões e observações relativas às estruturas de armazenamento, fornecendo um panorama técnico que pode servir de indício à realidade brasileira. Um ponto importante, levantado pela pesquisa, é que todos os participantes acreditam que o armazenamento desempenha um importante papel no gerenciamento das águas pluviais.

\footnotetext{
${ }^{108}$ Enviadas a cerca de 150 profissionais envolvidos no assunto, dos quais 65 atenderam à solicitação.
} 
Tabela 18 - Resposta ao questionário sobre práticas usuais, opiniões e observações

\begin{tabular}{|c|c|c|c|c|}
\hline Questões & Consultores & Governo & Acadêmicos & $\begin{array}{c}\text { Não } \\
\text { identificados }\end{array}$ \\
\hline $\begin{array}{l}\text { Porcentagem de participação } \\
\text { na pesquisa }\end{array}$ & 45 & 37 & 8 & 10 \\
\hline $\begin{array}{l}\text { Projetou ou analisou um } \\
\text { reservatório de armazenamento }\end{array}$ & 93 & 72 & 75 & 100 \\
\hline $\begin{array}{l}\text { Considerou uma faixa variável } \\
\text { de escoamento nos projetos } \\
\text { elaborados }\end{array}$ & 58 & 59 & 33 & 100 \\
\hline $\begin{array}{l}\text { Considerou a qualidade da } \\
\text { água nos projetos }\end{array}$ & 75 & 47 & 67 & 80 \\
\hline $\begin{array}{l}\text { Considera os reservatórios } \\
\text { importantes } \\
\text { gerenciamento do escoamento } \\
\text { superficial }\end{array}$ & 100 & 100 & 100 & 100 \\
\hline $\begin{array}{l}\text { Revisou ou inspecionou algum } \\
\text { reservatório }\end{array}$ & 89 & 88 & 50 & 100 \\
\hline $\begin{array}{l}\text { Consideram os reservatórios } \\
\text { eficientes na redução do pico } \\
\text { do escoamento superficial }\end{array}$ & 84 & 95 & 100 & 75 \\
\hline $\begin{array}{llr}\text { Consideram que } & \text { os } \\
\text { reservatórios melhoram } & \text { a } \\
\text { qualidade da água } & \end{array}$ & 80 & 76 & 100 & 100 \\
\hline
\end{tabular}

(Fonte: ASCE, 1982)

A ASCE (1982) considera difícil resumir as respostas da pesquisa, porém condensa algumas tendências gerais que são:

- A determinação das funções hidráulicas dos dispositivos de saída foi considerada uma das mais importantes etapa da elaboração dos projetos; 
- Segurança, a não ser para elaboração de um projeto prudente, não foi considerada como um elemento de grande importância pela maioria dos participantes;

- Manutenção e estética foram considerados de pouca importância pela maioria, exceto para os representantes governamentais que consideraram que os dois assuntos merecem atenção maior do que a atualmente dispensada;

- Considerações de projeto relativas à qualidade da água foram julgadas como relativamente importante, apesar do reconhecimento de que os reservatórios melhoram a qualidade da água;

- A maioria considera que o controle da variação de freqüência das chuvas deve ser considerada na elaboração dos projetos mas, ao mesmo tempo, não consideram importante converter as estruturas projetadas para uma só freqüência em estruturas para freqüência variadas.

Embasada nessa pesquisa, a ASCE (1982) concluiu que existe inconsistência e algumas confusões entre os profissionais sobre a elaboração de projetos de estruturas de saída e de reservatórios para controlar vazões com diferentes períodos de recorrência, apontando a necessidade de treinamento. Observa também que os reservatórios projetados para melhorar a qualidade da água estão sendo considerados insatisfatórios pelos órgãos governamentais. E finaliza dizendo que merece especial atenção a importância dada por esses órgãos à segurança, manutenção e estética, pois eles são, de forma geral, os responsáveis pela operação e manutenção dos reservatórios.

TUCCI e MARQUES (2000) avaliaram qual deveria ser o volume de detenção para controlar a ampliação de cheias em lotes ${ }^{109}$ de várias cidades brasileiras, baseado nas equações IDF elaboradas por Pfastetter em 1958, associadas ao método de McCuen. A tabela 19 ilustra os valores obtidos para um período de retorno de 5 anos, refletindo a grande variabilidade pluviométrica existente entre as

\footnotetext{
${ }^{109}$ Neste estudo foram adotados lotes de tamanhos entre 300 e $600 \mathrm{~m}^{2}$, usualmente utilizados nas cidades brasileiras, declividade do lote de $1 \%$, coeficiente de pré-ocupação de 0,1 e de pós-ocupação de 0,5 , além de período de retorno de 2 a 5 anos, sem levar em consideração aspectos construtivos e de manutenção, considerados fundamentais pelos autores para que o dispositivo seja eficiente.
} 
diversas regiões do Brasil e apresentando uma vazão específica média para os lotes estudados entre 5,69 a $7,39 \mathrm{l} / \mathrm{m}^{2}$.

Tabela 19 - Volume de detenção para controle de cheias em lotes de cidades brasileiras

\begin{tabular}{|c|c|c|c|c|}
\hline \multirow[t]{2}{*}{ Cidade } & \multicolumn{4}{|c|}{ Área dos lotes $\left(\mathrm{m}^{2}\right)$} \\
\hline & 300 & 400 & 500 & 600 \\
\hline Florianópolis & 1,21 & 1,87 & 2,43 & 3,33 \\
\hline Aracaju & 1,57 & 2,34 & 3,02 & 4,02 \\
\hline Belém & 1,93 & 2,89 & 3,72 & 4,96 \\
\hline Belo Horizonte & 1,94 & 2,89 & 3,72 & 4,94 \\
\hline Caixas do Sul & 1,49 & 2,23 & 2,88 & 3,85 \\
\hline Cuiabá & 2,14 & 3,18 & 4,10 & 5,44 \\
\hline Curitiba & 1,94 & 2,89 & 3,73 & 4,95 \\
\hline Fortaleza & 2,46 & 3,66 & 4,72 & 6,26 \\
\hline Goiânia & 2,14 & 3,19 & 4,10 & 5,44 \\
\hline Rio de Janeiro & 1,28 & 1,97 & 2,57 & 3,52 \\
\hline João Pessoa & 1,31 & 1,99 & 2,58 & 3,49 \\
\hline Maceió & 1,14 & 1,74 & 2,26 & 3,07 \\
\hline Manaus & 2,27 & 3,36 & 4,33 & 5,72 \\
\hline Natal & 1,37 & 2,05 & 2,65 & 3,54 \\
\hline Niterói & 1,91 & 2,86 & 3,68 & 4,91 \\
\hline Porto Alegre & 1,42 & 2,13 & 2,75 & 3,68 \\
\hline Porto Velho & 2,29 & 3,41 & 4,39 & 5,83 \\
\hline Rio Branco & 1,84 & 2,75 & 3,55 & 4,75 \\
\hline Salvador & 1,23 & 1,88 & 2,44 & 3,34 \\
\hline São Luiz & 1,50 & 2,30 & 2,98 & 4,07 \\
\hline São Carlos & 1,78 & 2,68 & 3,46 & 4,64 \\
\hline Uruguaiana & 1,41 & 2,16 & 2,80 & 3,83 \\
\hline Média & 1,71 & 2,56 & 3,31 & 4,44 \\
\hline Desvio padrão & 0,40 & 0,57 & 0,73 & 0,94 \\
\hline Coeficiente de variação & 0,23 & 0,22 & 0,22 & 0,21 \\
\hline Vazão específica $\left(\mathrm{l} / \mathrm{m}^{2}\right)$ & 5,69 & 6,41 & 6,62 & 7,39 \\
\hline
\end{tabular}

(Fonte: Tucci e Marques, 2000) 
CRUZ e AGRA (2001) verificaram a eficiência de reservatórios para controle distribuído frente a ocorrência de eventos reais de precipitação, em lote com as características e cenários apresentados na tabela 20. Utilizando o método de Pulz, realizaram várias simulações com variação de volume dos reservatórios e de dimensões das estruturas de saída, comparando as vazões de saída com as de préurbanização e obtiveram dimensões ótimas para a situação proposta, apresentadas na tabela 21. Com o reservatório definido, analisaram seu comportamento em 8 eventos reais de chuvas, com período de recorrência variando de 0,14 a 7,09 anos e duração de 1 hora.

Tabela 20 - Características e cenários de verificação

\begin{tabular}{|l|c|c|}
\hline Parâmetro & Pré-urbanização & Pós-urbanização \\
\hline Dimensões & \multicolumn{2}{|c|}{$15,0 \mathrm{~m}$ x 20,0 } \\
\hline Declividade & $0,0100 \mathrm{~m} / \mathrm{m}$ \\
\hline Área impermeável & 20 & $80 \%$ \\
\hline Tempo de concentração (minutos) & 87,44 & 7 \\
\hline Intensidade de chuva (mm/h) & 83 & 138,16 \\
\hline CN & 0,17 & 0,83 \\
\hline Volume escoado/volume precipitado & 1,10 & 7,50 \\
\hline Vazão de pico (1/s) & 36,7 & 250 \\
\hline Vazão específica (1/s ha) & \multicolumn{2}{|c|}{} \\
\hline
\end{tabular}

(Fonte: Cruz e Agra, 2001)

CRUZ e AGRA (2001) observaram então que a eficiência do microreservatório está intrinsecamente ligada à intensidade da precipitação, bem como à sua distribuição temporal, principalmente com relação à distribuição dos picos de chuva no tempo, e concluíram que as técnicas de dimensionamento devem ser revistas e aprimoradas, buscando uma maior representatividade do comportamento temporal das precipitações na região de implantação do dispositivo. 
Os autores levantam a necessidade de analisar a atuação de microreservatórios capazes de permitir a passagem de uma determinada vazão, sem utilizar o volume de amortecimento, permitindo o armazenamento a partir do momento em que a vazão limite é superada, otimizando o uso do volume disponível e resguardando-o para atuar sobre os picos principais gerados.

Tabela 21 - Dimensões ótimas dos reservatórios

\begin{tabular}{|l|c|}
\hline Microreservatório & Valores \\
\hline Volume $\left(\mathrm{m}^{3}\right)$ & 3,50 \\
\hline Profundidade $(\mathrm{m})$ & 0,50 \\
\hline Área $\left(\mathrm{m}^{2}\right)$ & 7,00 \\
\hline Diâmetro do orifício $(\mathrm{mm})$ & 30 \\
\hline Largura do vertedor $(\mathrm{m})$ & 2,00 \\
\hline Altura do vertedor $(\mathrm{m})$ & 0,45 \\
\hline
\end{tabular}

(Fonte: Cruz e Agra, 2001)

NASCIMENTO, ELLIS e DEUTSCH (1999) fizeram uma análise das experiências práticas das soluções de armazenamento na França, Reino Unido e Belo Horizonte, com o intuito de averiguar vantagens e limitações para continuidade e expansão do uso de reservatórios de detenção no Brasil e concluíram que, de forma geral, problemas de operação e manutenção, erosão, sedimentação e outras fontes de poluição têm sido responsáveis pela redução da vida útil dos reservatórios de detenção/retenção no Brasil.

A falta de monitoramento dos processos físicos combinado com a falta de adequado investimento em projeto e gerenciamento desses reservatórios, não tem contribuído para o conhecimento detalhado das causas das operações precárias e para uma análise efetiva de custos e benefícios.

As experiências européias e brasileiras no uso de reservatórios de detenção, confirmam que problemas de concepção, dimensionamento e gerenciamento são muito complexos quando os objetivos são multifuncionais e direcionados para 
controle de enchentes, poluição e recreação dentro de um cenário urbano, ressaltando também que a transferência direta de tecnologia nem sempre é apropriada. Essa transferência deve incluir considerações sobre as condições socioeconômicas e administrativas locais, associadas com a operacionalidade, que podem constituir-se em vetores de restrição a implantação de tecnologias inovadoras.

A sustentabilidade a longo prazo dos projetos convencionais de armazenamento de cheias são muito diferentes quando implantados no contexto brasileiro, resultando em baixa performance e consideráveis gastos com manutenção e reabilitação dos sistemas. É essencial enfatizar a importância da coleta de informação e do desenvolvimento sistemático de banco de dados sobre operação de reservatórios de detenção, particularmente no Brasil. O estudo desses dados pode fornecer informações relevantes sobre a evolução dos processos hidrológicos e ambientais, o estabelecimento de critérios apropriados, as formas de implementação de redes de monitoramento e de programas de manutenção, a integração no contexto urbano e os custos de implantação e manutenção. Essas pesquisas são indispensáveis para o uso efetivo e econômico das bacias de detenção como soluções compensatórias dos impactos da urbanização.

NASCIMENTO, ELLIS e DEUTSCH (1999) concluem que existe a necessidade de repensar os critérios básicos de projeto em termos de princípios de funcionamento, operação e manutenção dos reservatórios de armazenamento para o cenário brasileiro.

Nesse cenário, onde o processo de implementação de uma lei é lento e o sistema de fiscalização deficiente, ao se planejar o desenvolvimento de uma área, deve-se reservar espaços para amortecimento da vazão excedente, para o caso em que o controle na origem não funcione adequadamente. PARKINSON et al (2003) consideram que, normalmente, são necessários aproximadamente $2 \%$ da área para amortecer a inundação de uma área urbanizada e esta deve ser reservada junto à parcela de área pública do empreendimento. 


\subsection{Legislação Específica}

No Brasil, a implantação de pequenos reservatórios de detenção tem sido normalmente viabilizada por força de legislações criadas pelos municípios, como por exemplo em Belo Horizonte, São Paulo e Porto Alegre ${ }^{110}$ (GOMES, BAPTISTA e NASCIMENTO, 2003). No exterior, principalmente nos Estados Unidos onde o departamento de proteção ambiental - EPA - tem realizado trabalho intenso de incentivo a práticas alternativas e educação ambiental, comunidades já se organizam e por iniciativa própria tem viabilizado a implantação desses dispositivos de drenagem urbana.

Legislação específica para implantação de reservatórios de detenção, principalmente em lotes, deve ser fruto do planejamento da bacia hidrográfica e não de modismos casuais, promoção política ou intempestividade. Para que este dispositivo funcione a contento, é necessário que exista uma integração de objetivos e ações, inclusive de outros setores, como por exemplo a definição do uso e ocupação do solo, com suas respectivas fiscalizações e regulamentações.

Recomenda-se cautela aos municípios na imposição de implantação de reservatórios de detenção para que não se agrave a situação existente e nem se restrinja às alternativas possíveis de controle de cheias, uma vez que é preciso evitar expedientes imediatistas e aproveitar as oportunidades existentes nos novos projetos.

É sempre mais interessante a determinação de critérios e parâmetros devidamente conceituados, avaliados e adequados às características naturais e urbanísticas locais, assim como à população residente, contemplando as múltiplas formas de controle de cheias urbanas, do que engessar o sistema com imposições difíceis de serem atendidas e cuja eficácia possa ser contestada.

A OMS - Organização Mundial da Saúde - por exemplo, reconhecendo a diversidade de locais onde suas diretrizes poderão ser adotadas, considera mais adequado prescrever metodologias preventivas e concretas do que padrões regulatórios pouco efetivos (HELMER, HESPANHOL e SABILBA, 1991).

A criação de legislações específicas deve, portanto, ponderar sobre essa questão, principalmente porque existe ansiedade do poder municipal em criar

${ }^{110}$ Lei $\mathrm{n}^{\mathrm{o}} 7.166$ de $27 / 08 / 1996$, Lei $\mathrm{n}^{\mathrm{o}} 13.276$ de $05 / 01 / 2002$ e Plano diretor de drenagem urbana, 
regulamentações sobre questões ambientais e práticas consideradas contemporâneas e ecologicamente corretas.

É fundamental também que a legislação específica discorra genericamente sobre o embasamento teórico de suas fundamentações técnicas e parâmetros gerais a serem observados, sobretudo quando são apresentadas fórmulas de dimensionamento para que os demais componentes do sistema de drenagem sejam, da mesma forma, adequados às premissas utilizadas e possam orientar os profissionais no desenvolvimento dos trabalhos e produzir soluções compatíveis com os objetivos esperados.

Para definição das vazões a serem consideradas no dimensionamento dos reservatórios de detenção em lotes, por exemplo, "é necessário estabelecer critérios simples que sejam aplicáveis de forma geral na cidade, sem prejuízo do seu controle, pois não é possível esperar que seja realizado um estudo hidrológico a cada novo empreendimento de pequenas áreas, como lotes ou mesmo loteamento menores" (TUCCI e MARQUES, 2001).

Legislações específicas sobre implantação de estruturas de armazenamento, em especial reservatórios de detenção em lotes, não devem anteceder a elaboração dos Planos Diretores de Drenagem Urbana para que as orientações de macro e microdrenagem de uma bacia estejam sincronizadas e que seus princípios criem um sistema harmônico, evitando os possíveis efeitos adversos impostos pela junção de diferenciados e aleatórios critérios de concepção, dimensionamento, operação e manutenção.

A integração entre micro e macrodrenagem deve consolidar diretrizes, respeitando as características e comportamentos observados nas bacias de contribuição, maximizar o controle sobre o escoamento superficial gerado, reduzir custos e proteger o meio ambiente. Segundo a CETESB (1986), "um plano homogêneo traz melhores resultados do que projetos de drenagem isolados, desenvolvidos sob critérios diferentes" e McCUEN, WALESH e RAWIS (1983) observam que para obter uma estimativa consistente, é prudente unificar as metodologias de projetos aplicada a uma mesma região.

17/06/2002, respectivamente. 
SPIRN (1995) cita a cidade de Denver, no Colorado como um exemplo significativo de uma cidade que implementou um conjunto de estratégias abrangentes e coordenadas para a administração de suas águas, observando que anteriormente a essa implementação, cada um dos 34 governos locais utilizava métodos diferentes para calcular os riscos das enchentes e projetar a capacidade de seus sistemas de drenagem: "alguns projetaram sistemas para acomodar uma chuva de 50 anos, outros tomaram providências para tempestades de 2 anos".

Uma lacuna deixada por este tipo de legislação é sua efetiva fiscalização, uma vez que provavelmente não haverá como executar uma fiscalização rigorosa devido à multiplicação dos pontos de fiscalização e o contingente normalmente disponível nos quadros das prefeituras para esta finalidade. Some-se a isso, o dinamismo dos processos urbanos que dificultam ainda mais esse tipo de controle. Neste ponto, é mais eficiente e prática a implantação de reservatórios únicos para uma certa área de abrangência e a divisão de seu ônus entre seus demandantes.

Segundo o CBH-AT (2002), "não se recomendam restrições sobre o pequeno lote pulverizado, pois a experiência tem demonstrado que o controle nesses casos é tecnicamente complexo e politicamente desgastante, tendendo à inviabilidade”, além de ser claramente uma solução anti-econômica quando aplicada a lotes pequenos, comparada às soluções mais centralizadas de controle.

SPIRN (1995) concorda que a prevenção de enchentes, assim como a conservação e recuperação da água, só poderão ser realizadas pelo efeito cumulativo de muitas ações individuais por toda a cidade, porém ressalta que o impacto de cada uma delas pode ser insignificante e até contraproducente, se não fizer parte de um plano global que leve em consideração o sistema hidrológico de toda a cidade e de sua região. Para ela, cada cidade deve desenvolver uma estrutura na qual as conseqüências dos maiores esforços metropolitanos, além dos efeitos cumulativos das ações individuais, possam ser apreciados.

A questão central quanto à implantação de reservatórios de detenção em lotes ou por área de abrangência é determinar os responsáveis pela operação e manutenção destes sistemas, incluindo seus custos, o que também deve ser ponderado pelas legislações específicas. 
PARKINSON et al (2003) ressaltam as dificuldades que as administrações municipais já possuem de utilizarem os mecanismos de controle existentes, tanto pela escassez de técnicos especializados e a necessidade de suporte técnico, quanto pelos parcos recursos disponíveis.

MEDEIROS (1999), observa que "a maioria das prefeituras são totalmente desprovidas de recursos humanos e materiais para enfrentar os problemas relativos aos recursos hídricos do município e mesmo aquelas que declaram dispor de recursos humanos, são esses insuficientes em quantidade e qualidade", demonstrando a carência municipal de profissionais e recursos organizacionais, creditados na maioria das vezes às deficiências financeiras.

Entretanto, os governantes, na qualidade de administradores das cidades, não devem se omitir quanto à drenagem urbana, mas sim chamar para si a responsabilidade, solicitando a participação da sociedade e buscando assistência quando necessário. Devem também prever problemas futuros e propor medidas mitigatórias e/ou compensatórias de encaminhamento à soluções viáveis e efetivas.

Municípios menores, ainda em plena fase de expansão, precisam estar atentos aos conceitos atuais de drenagem urbana e não se espelhar nos municípios mais desenvolvidos, para que possam criar soluções mais adequadas à realidade local e às suas exigências de desenvolvimento, evitando problemas criados pela falta de planejamento e ocupação desordenada, característicos dos grandes centros urbanos, pois "todos os processos inadequados de urbanização e impacto ambiental observados nas regiões metropolitanas estão se reproduzindo nas cidades de médio porte" (TUCCI e MARQUES, 2001).

LAWRENCE et al. (1996) citado por GRACIOSA (2004) lembra que, de forma geral, é inviável a recuperação das condições de escoamento anteriores à urbanização em áreas já estabelecidas, e portanto, as metas dos programas de gestão das águas pluviais e as legislações específicas devem ser estruturadas para limitação dos impactos a níveis aceitáveis.

Registra-se aqui, que a localização das legislações sobre reservatórios de detenção é dificultada pela falta de denominação específica, que varia de município para município (caixa de armazenamento e drenagem, dispositivo de diminuição da vazão máxima de águas pluviais, etc.) e pela diversidade de locais onde é possível 
encontrar referências a esse respeito (planos diretores, leis de uso e ocupação do solo, código de obras, etc.).

Para apreciar o conteúdo e implicações das legislações específicas existentes sobre a implantação de reservatórios de detenção em lotes, apresenta-se a seguir uma análise da legislação em vigor nos municípios de São Paulo e Porto Alegre.

\subsubsection{Município de São Paulo}

A Lei municipal $n^{\circ} 13.276$ de 04 de janeiro de 2002, tornou obrigatória a execução de reservatórios de águas pluviais em lotes, edificados ou não, com área impermeável superior a $500 \mathrm{~m}^{2}$, no município de São Paulo. Sua regulamentação ocorreu em 15 de março do mesmo ano, através do Decreto municipal $\mathrm{n}^{\circ} 41.814$.

A necessidade de implantação de reservatórios de águas pluviais aplica-se, a partir da publicação da Lei, a todos os projetos de regularização e obras de novas edificações, assim como aos projetos modificativos de obras novas de edificações já aprovadas ou reforma (para estes dois últimos, quando houver acréscimo de área impermeabilizada igual ou superior a $100 \mathrm{~m}^{2}$ ).

A referida Lei, em seu artigo $2^{\circ}$, fornece para o cálculo do volume do reservatório de águas pluviais a seguinte expressão:

$$
\mathrm{V}=0,15 \times \mathrm{Ai} \times \operatorname{IP} \times \mathrm{t}
$$

Onde: $\mathrm{V}=$ volume do reservatório $\left(\mathrm{m}^{3}\right)$

$$
\mathrm{Ai}=\text { área impermeabilizada }\left(\mathrm{m}^{2}\right)
$$$$
\text { IP = índice pluviométrico igual a } 0,06 \mathrm{~m} / \mathrm{h}
$$$$
\mathrm{t}=\text { tempo de duração da chuva igual a } 1 \text { hora }
$$

Para utilização desta fórmula, entende-se como área impermeabilizada "toda água captada por telhados, coberturas, terraços e pavimentos descobertos”, pois estas terão por destino o reservatório de águas pluviais. 
O índice pluviométrico adotado, apesar de não discriminado, apresenta período de retorno de 10 anos, para uma chuva com duração de 1 hora, que é o tempo mínimo que a água pluvial deve ficar armazenada antes de seu lançamento na rede pública de drenagem.

Essa imposição de reservação mínima por 1 hora é de difícil atendimento, pois pressupõe basicamente utilização de equipamento elétrico ou muita criatividade, uma vez que é impossível prever a intensidade das precipitações e garantir o armazenamento apenas com dispositivos simples, como vertedores ou orifícios.

É certo que pela legislação é dada preferência à infiltração dessa água no solo, porém nem sempre esta solução é recomendável ou viável, principalmente se for considerada a taxa de infiltração necessária para garantir o esvaziamento em apenas 1 hora.

Outra possibilidade oferecida é a utilização da água para fins não potáveis e neste caso, é necessária a implantação de um outro reservatório, pois espera-se que o reservatório de armazenamento de águas pluviais esteja sempre vazio para alcançar seus objetivos.

Além disso, a expressão acima apresenta um redutor, similar ao coeficiente de escoamento superficial "C" encontrado no Método Racional para representação da permeabilidade da bacia contribuinte, que abate consideravelmente o volume de armazenamento. Isso significa que o extravasor será um dispositivo freqüentemente solicitado, já que áreas impermeáveis irão produzir vazões semelhantes a áreas de subúrbios com pequena densidade de construção ou matas, parques e campos de esporte sem pavimentação.

Esta fórmula é a mesma presente na Lei no 11.228, de 25 de junho de 1992, que institui o Código de Obras e Edificações, onde está prevista a obrigatoriedade de manutenção de $15 \%$ de área permeável nos lotes e/ou a construção de reservatório para garantir as condições naturais de absorção das águas pluviais. Talvez nesta situação, possa-se justificar o coeficiente 0,15 da expressão acima, que corresponderia aos $15 \%$ de área que pretende-se manter permeável, porém esse índice deveria incidir sobre a área total do terreno e não somente sobre a área impermeabilizada. 
Por outro lado, essa redução de volume pode ter sido proposital, com o intuito de facilitar a implantação dos reservatórios em função do pouco espaço disponível nos lotes urbanos em São Paulo.

Outra imposição que dificulta e restringe diferentes soluções é a necessidade de criar reservatórios fechados e cobertos, atendendo às normas sanitárias vigentes. Deduz-se desta solicitação, primeiro que há uma preocupação com a segurança e segundo, que o armazenamento da água pluvial pode trazer problemas de manutenção e saúde, servindo de alerta para os empreendedores.

O texto de regulamentação da Lei diz somente que deverá ser indicada a localização do reservatório, apresentado o cálculo do seu volume e uma descrição sucinta do sistema instalado, porém não faz nenhuma referência à verificação da eficiência do sistema proposto, que é o ponto fundamental para alcançar seus objetivos. Provavelmente esta forma simplificada de fiscalização deva-se ao fato de não haver profissionais suficientes no corpo técnico da prefeitura para averiguar toda a enorme gama de soluções passíveis de apresentação.

Enquanto não houver a normatização, pelo menos de parte dos dispositivos que compõem os reservatórios de detenção, uma análise mais apurada consumirá tempo considerável e esta não é a finalidade da lei.

Para contornar esta dificuldade, é solicitada uma declaração assinada pelo dirigente técnico e pelo proprietário, dizendo que a edificação atende a Lei e a regulamentação sobre reservatórios de águas pluviais, inclusive quanto às condições sanitárias, eximindo de certa forma a municipalidade, pelo não funcionamento do sistema ou da criação de condições adversas. Porém, como parte dela, a exigência de implantação de reservatórios nos termos acima apresentados, lhe é devida certa parcela de responsabilidade, pois não é lícito solicitar dispositivos que possam causar transtornos sem fazer as devidas considerações preventivas.

Finalmente, a aplicação desta lei está vinculada à obtenção do Certificado de Conclusão ou Auto de Regularização, o que a torna pouco eficiente perante o crescimento irregular e a ocupação clandestina, verificada principalmente na periferia e nas áreas sensíveis a inundações. Sabe-se que estas são exatamente as regiões onde se observa o maior crescimento e a maior carência de infraestrutura. 
Ficam marginalizadas do mesmo modo, todas as edificações existentes, que correspondem à grande maioria das edificações que compõem os centros urbanos, mostrando-se um sistema pouco eqüitativo, uma vez que todos, antigos e novos empreendimentos, contribuem igualmente na produção do escoamento superficial. Para equilibrar tal situação, seria justo implantar concomitantemente, um sistema de tributação, que levasse em consideração além da área impermeabilizada, a idade do imóvel (oportunidade de criação de áreas de controle durante a fase de projeto) e criasse incentivos para o aumento voluntário da permeabilidade, porém considerando não somente os reservatórios de armazenamento, mas também outras formas alternativas de redução de escoamento excedente.

Perante o exposto, sugere-se a revisão desta Lei e de sua regulamentação para torná-la mais flexível e factível com as possibilidades de implantação de um reservatório de detenção. Incentivos a outra práticas de redução do escoamento superficial também são bem vindos e necessários, assim como orientações, parâmetros e critérios a serem adotados em cada caso.

\subsubsection{Município de Porto Alegre}

A implantação de reservatórios de águas pluviais em lote ou loteamentos na cidade de Porto Alegre foi proposta pelo Plano Diretor de Drenagem Urbana em 2002, com o intuito de prevenir o aumento das inundações e manter as condições naturais pré-existentes de vazão.

Para atingir estes objetivos, foi solicitado que toda ocupação que resulte em superfície impermeável e todo parcelamento do solo, mantivesse uma vazão máxima específica de saída para a rede pública de águas pluviais menor ou igual a 20,8 1/ (s.ha), excetuando-se terrenos com área inferior a $600 \mathrm{~m}^{2}$ que deverão consultar primeiramente, o Departamento de Esgotos Pluviais.

Para computo da vazão máxima de saída considera-se a área total do terreno e é permitida a drenagem direta para o sistema de águas pluviais apenas das áreas dos recuos mantidas como áreas verdes. 
A vazão específica de 20,8 1/ (s.ha) foi obtida considerando uma bacia urbana correspondente a 100 ha com comprimento de cerca de duas vezes a largura, tempo de concentração de 1 hora, período de retorno de 10 anos e curva IDF do posto de Redenção (Porto Alegre), conforme discriminado por TUCCI e MARQUES (2001) e aprovado pelo Conselho do Plano Diretor de Porto Alegre.

A comprovação da manutenção das condições de pré-ocupação, ou seja da vazão específica, deve ser apresentada ao Departamento de Esgotos Pluviais para avaliação. Terrenos com área superior a 100 ha, farão a comprovação através de estudos hidrológicos específicos para período de retorno de 10 anos. Terrenos com área inferior a 100 ha e controle de vazão através de reservatório, deverão armazenar o volume determinado pela expressão abaixo, que considera as condições naturais do terreno e a vazão máxima específica permissível após seu desenvolvimento, já citada anteriormente:

$$
\mathrm{V}=4,25 \mathrm{Ai}
$$

Onde: $\mathrm{V}=$ volume por unidade de área do terreno $\mathrm{em} \mathrm{m}^{3} / \mathrm{ha}$ $\mathrm{Ai}=$ área impermeável do terreno em porcentagem.

A adoção de diferentes critérios para terrenos com mais ou menos que 100 ha, demonstra que há uma postura de simplificação para casos mais rotineiros, e de maior rigor para controle de vazões de porte e impacto mais significativos, facilitando tanto o trabalho do corpo técnico municipal, como respeitando as hipóteses utilizadas na determinação da equação acima mencionada e seus limites de aplicação.

Para utilização da equação acima é permitido deduzir da parcela da área impermeável correspondente, uma porcentagem que varia em função do tipo de solução alternativa utilizada para auxiliar na redução da produção de escoamento superficial, desde que comprovada as condições mínimas de infiltração no solo, ou seja, redução de 50\% para áreas que utilizam pavimentos permeáveis, 40 a $80 \%$ para áreas não diretamente conectadas e $80 \%$ para áreas encaminhadas a trincheiras de infiltração. 
Esta postura incentiva a procura por soluções que utilizem a disposição local das vazões excedentes e colabora para a redução das dimensões dos sistemas de drenagem a jusante.

Está previsto também, que regras de dimensionamento e construção, tanto dos reservatórios como das soluções auxiliares para redução da área impermeável, deverão ser contempladas no Manual de Drenagem Urbana do Plano Diretor de Drenagem Urbana de Porto Alegre, o que vem a sanar possíveis dúvidas existentes por parte dos profissionais no cumprimento da legislação.

De forma geral, em comparação com a legislação específica de São Paulo, esta legislação é melhor embasada e elaborada, principalmente por estar respaldada pelo Plano Diretor de Drenagem Urbana, por abranger não somente lotes mas também loteamentos, por não impor restrições ao desenvolvimento dos reservatórios e suas formas de armazenamento e por incentivar práticas sustentáveis de disposição local do escoamento excedente. 


\section{COMPANHIA DE DESENVOLVIMENTO HABITACIONAL E URBANO DO ESTADO DE SÃO PAULO - CDHU}

A CDHU - Companhia de Desenvolvimento Habitacional e Urbano do Estado de São Paulo é uma empresa do Governo Estadual, vinculada à Secretaria da Habitação, que tem por finalidade executar programas habitacionais voltados para o atendimento exclusivo da população de baixa renda em todo o Estado de São Paulo (CDHU, site).

A empresa que foi fundada em 1949 é hoje, uma das maiores companhias habitacionais do mundo. Desde que iniciou suas atividades, com atuação mais intensa nos últimos 20 anos, construiu e comercializou aproximadamente $361 \mathrm{mil}$ habitações, em cerca de 2164 conjuntos habitacionais implantados em 601 municípios paulistas, atendendo uma população de aproximadamente 1 milhão e 100 mil pessoas (CDHU, site).

Os principais objetivos da CDHU são (CDHU, site):

- Redução do déficit habitacional no estado de São Paulo;

- Produção em larga escala para população de baixa renda;

- Melhoramento de assentamentos e unidades habitacionais;

- Erradicação de favelas e cortiços.

As necessidades habitacionais (déficit habitacional ${ }^{111}+$ domicílios inadequados $^{112}$ ) no estado de São Paulo podem ser observados na tabela 22, onde ressalta-se a aglomeração humana nos grandes centros e a importância dos trabalhos desenvolvidos pela Companhia.

\footnotetext{
${ }^{111}$ Enquadram-se no déficit habitacional, as moradias com carências graves que não podem ser superadas por meio de reformas e melhorias, em face da precariedade em que se encontram, ou seja, domicílios que requerem substituição.

${ }_{112}$ Domicílios inadequados são aqueles com carências que podem ser resolvidos por reformas ou melhorias, apresentando pelo menos uma das seguintes características: moradia em favela ou cortiço, espaço interno insuficiente (não dispõe de composição mínima de quarto, sala, cozinha e banheiro), congestionamento (mais de 1 pessoa por cômodo, mais de 2 pessoas por quarto e onde sala ou cozinha é ocupada para dormir), comprometimento excessivo de renda com aluguel, infra-estrutura interna imprópria (falta de energia elétrica, água, lixo ou esgoto).
} 
Tabela 22 - Déficit e necessidades habitacionais no estado de São Paulo

\begin{tabular}{|l|c|c|c|c|}
\hline Item & Estado & \% & RMSP & $\%$ \\
\hline $\mathrm{N}^{\circ}$ total de domicílios & 7.792 .000 & 100,00 & 4.811 .000 & 100,00 \\
\hline Déficit habitacional & 800.000 & 10,27 & 561.000 & 11,66 \\
\hline Domicílios inadequados & 2.369 .000 & 30,40 & 1.784 .000 & 37,08 \\
\hline $\begin{array}{l}\text { Total das } \\
\text { necessidades } \\
\text { habitacionais }\end{array}$ & 3.169 .000 & 40,67 & 2.345 .000 & 48,74 \\
\hline
\end{tabular}

(Fonte: SEADE, 2002 apud CDHU, 2003)

O principal recurso financeiro da CDHU para alcançar seus objetivos e que propiciou a produção em larga escala, é proveniente da alíquota de 1\% do ICMS Imposto sobre Circulação de Mercadorias e Serviços ${ }^{113}$ (CDHU, site). A companhia conta também com recursos de sua carteira de mutuários e com financiamento externo para programas específicos, como por exemplo aqueles obtidos junto ao BID - Banco Interamericano de Desenvolvimento.

A prioridade de assistência são famílias com renda entre 1 e 3 salários mínimos, porém a companhia atende famílias com rendimento até 10 salários mínimos ${ }^{114}$, dependendo do tipo de programa habitacional (CDHU, site).

A definição do tipo de programa a ser utilizado em cada caso, é realizado após identificação e caracterização da demanda, das possibilidades de parcerias e contrapartida das prefeituras, empresas construtoras e entidades organizadas (parceiros da CDHU na viabilização de conjuntos habitacionais), e principalmente após os estudos de viabilidade econômica. A comparação entre esses fatores e as premissas estabelecidas em cada programa balizam a escolha do programa mais adequado, assim como indicam a necessidade de novas tratativas e esforços para enquadramento em uma das alternativas oferecidas.

\footnotetext{
${ }^{113}$ Lei Estadual $n^{\circ} 6556$ de 30/11/1989, artigo 3o , renovado anualmente pela Assembléia Legislativa (aproximadamente $\mathrm{R} \$ 600.000 .000,00$ por ano) (CDHU, site).

${ }^{114}$ Segundo CDHU/FIA (2002) à partir do $7^{\circ}$ salário mínimo já é possível obter alternativas no mercado imobiliário.
} 
A forma de acesso da população aos empreendimentos da CDHU, também depende dos programas, mas de maneira geral é feita através de inscrições e a contemplação através de sorteios públicos.

Como pré-requisito, é necessário residir ou trabalhar no município onde está sendo realizado o empreendimento a mais de três anos, e não ser proprietária de imóvel urbano ou rural ou de qualquer modalidade de financiamento habitacional.

Para determinados tipos de programas, é obrigatório a destinação específica de unidades habitacionais para deficientes ${ }^{115}$, idosos ${ }^{116}$ e policiais ${ }^{117}$, conforme legislação em vigor.

O valor do imóvel, com base no $2^{\circ}$ semestre de 2003, gira entre $\mathrm{R} \$ 45.000,00$ (unidade vertical em região metropolitana) e R\$ 12.500,00 (construção através de processo de mutirão com terreno doado), com juros de $1 \%$ durante a fase de construção, e no máximo 5,7\% na fase do retorno do investimento (CDHU, 2004).

O comprometimento máximo da renda familiar varia de $15 \%$ à $30 \%$, baseado na proporcionalidade entre renda familiar e prestação. Subsídios temporários e decrescentes com o tempo ${ }^{118}$, entre $15 \%$ e $30 \%$, são também distribuídos de acordo com a renda familiar (CDHU, site).

O prazo de financiamento é de 25 anos (CDHU, 2004).

\footnotetext{
$1157 \%$, conforme lei 10.844 de julho/01.

116 5\%, conforme lei 8.892/ 97 - Política Estadual do Idoso

$1174 \%$ para policiais civis e militares, conforme lei 11.023 de dezembro/01

${ }^{118}$ Lei Estadual n $^{\circ} 6556$ de 30/11/1989, artigo $7^{\circ}$.
} 


\subsection{Características da População Beneficiária}

A população beneficiária da CDHU forma um segmento específico, definido primeiramente, pelos critérios de habilitação de cada programa habitacional, que considera a camada da população a ser atingida.

Para caracterização da população beneficiária serão analisados o perfil sóciodemográfico, as condições econômicas e o perfil educacional das famílias inscritas.

\subsubsection{Perfil Sócio-Demográfico}

O perfil sócio-demográfico é composto pelo perfil etário e pelo perfil da composição familiar.

O perfil etário (tabela 23) confirma a tendência de maior concentração de indivíduos nas faixas jovens, como decorrência do próprio critério de limite de idade do chefe da família para acesso aos programas ${ }^{119}$.

Tabela 23 - Perfil etário da população atendida pela CDHU

\begin{tabular}{|c|c|c|c|c|c|}
\hline \multirow{2}{*}{$\begin{array}{c}\text { Faixa etária } \\
(\operatorname{anos})\end{array}$} & \multirow{2}{*}{$\begin{array}{c}\text { Interior } \\
(\%)\end{array}$} & \multicolumn{3}{|c|}{ RMSP } & \multirow{2}{*}{$\begin{array}{c}\text { Estado } \\
\text { (média \%) }\end{array}$} \\
\hline & & $(\%)$ & (\% homens) & (\% mulheres) & \\
\hline 0 a 6 & 19,3 & 19,4 & 21,2 & 17,6 & 19,3 \\
\hline 7 a 17 & 23,6 & 21,5 & 23,1 & 20,3 & 22,6 \\
\hline 18 a 55 & 51,9 & 56,3 & 53,5 & 58,6 & 54,1 \\
\hline acima 55 & 5,2 & 2,8 & 2,2 & 3,5 & 4,0 \\
\hline total & 100 & 100 & 100 & 100 & 100 \\
\hline
\end{tabular}

(Fonte: CDHU, 1992 e CDHU/SEADE, 1998)

O perfil da composição familiar apresenta $67 \%$ de famílias com núcleo central composto por casal, presença de filhos em 75,6\% dos lares e chefia

${ }^{119}$ Idade máxima de 55 anos. 
feminina em $20 \%$ das famílias pesquisadas (tabela 24). Trata-se de família pequena, composta na média por 3,4 indivíduos ${ }^{120}$, não havendo variação entre famílias do interior e da RMSP (tabela 24).

Tabela 24 - Número de indivíduos das famílias atendidas pela CDHU

\begin{tabular}{|c|c|c|c|c|c|c|}
\hline \multirow[b]{2}{*}{ tipo de família } & \multirow{2}{*}{$\begin{array}{c}\text { Composição } \\
\text { familiar } \\
(\%)\end{array}$} & \multicolumn{4}{|c|}{ número de indivíduos } & \multirow{2}{*}{ média } \\
\hline & & 2 & 3 & 4 & 5 ou mais & \\
\hline casal sem filhos & 14,8 & 100,0 & 0,0 & 0,00 & 0,0 & 2,00 \\
\hline casal com filhos & 45,0 & 0,0 & 43,1 & 31,8 & 25,1 & 7,51 \\
\hline chefe mulher com filhos & 19,9 & \multirow{2}{*}{42,0} & \multirow{2}{*}{32,7} & \multirow{2}{*}{15,3} & \multirow{2}{*}{10} & \multirow{2}{*}{6,55} \\
\hline chefe homem com filhos & 1,9 & & & & & \\
\hline casal com parentes & 1,9 & 0,0 & (1) & (1) & (1) & 3,36 \\
\hline casal, filhos e parentes & 5,3 & 0,0 & 0,0 & (1) & 63,6 & 5,26 \\
\hline chefe, filhos e parentes & 10,5 & 0,0 & 38,3 & 26,5 & 35,2 & 4,18 \\
\hline total & 100,0 & 27,1 & 32,4 & 22,0 & 18,6 & 3,43 \\
\hline
\end{tabular}

(Fonte: CDHU/SEADE, 1998)

(1) a amostra não comporta a desagregação para esta categoria

\subsubsection{Condições econômicas}

Para avaliação das condições econômicas são apreciados três itens: renda familiar, tipo de ocupação do chefe de família e custos habitacionais ${ }^{121}$.

A distribuição das famílias cadastradas segundo a variável renda, aponta a maior concentração na faixa entre 3 e 5 salários mínimos - sm, conforme tabela 25.

\footnotetext{
${ }^{120}$ Um dos critérios de habilitação é a da composição familiar por no mínimo duas pessoas.

121 Soma de todos os itens efetivamente pagos pela família: água, eletricidade, gás, aluguel, financiamento, condomínio, etc..
} 
Tabela 25 - Faixa de renda das famílias cadastradas

\begin{tabular}{|l|c|c|c|}
\hline \multicolumn{1}{|c|}{ Renda familiar } & $\begin{array}{c}\text { Interior } \\
(\%)\end{array}$ & $\begin{array}{c}\text { RMSP } \\
(\%)\end{array}$ & $\begin{array}{c}\text { Estado } \\
(\text { média } \%)\end{array}$ \\
\hline até $2 \mathrm{sm}$ & 8,4 & 6,8 & 7,6 \\
\hline 2 a $3 \mathrm{sm}$ & 13,9 & 18,4 & 16,1 \\
\hline 3 a $5 \mathrm{sm}$ & 31,4 & 35,7 & 33,6 \\
\hline 5 a $7 \mathrm{sm}$ & 22,3 & 20,6 & 21,4 \\
\hline 7 a $10 \mathrm{sm}$ & 17,2 & 14,5 & 15,9 \\
\hline acima de $10 \mathrm{sm}$ & 6,8 & 4,0 & 5,4 \\
\hline total & 100 & 100 & 100 \\
\hline
\end{tabular}

(Fonte: CDHU, 1992 e CDHU/SEADE, 1998)

Com relação ao tipo de ocupação do chefe de família (tabela 26), a proporção daqueles que trabalham como assalariado é a mais elevada $(73,3 \%)$, sendo grande parte deste total pertencente ao setor privado com carteira assinada ou ao setor público $(56,0 \%)$.

Tabela 26 - Tipo de ocupação do chefe de família

\begin{tabular}{|l|c|}
\hline \multicolumn{1}{|c|}{ Ocupação do chefe de família } & porcentagem \\
\hline assalariado do setor privado ou público com carteira & 56,0 \\
\hline assalariado do setor privado sem carteira assinada & 17,3 \\
\hline autônomo & 15,9 \\
\hline empregador (1) & 3,3 \\
\hline empregado doméstico & 7,5 \\
\hline total & 100,0 \\
\hline
\end{tabular}

(Fonte: CDHU/SEADE, 2001)

(1) inclui dono de negócio familiar e profissional universitário autônomo

A "estimativas de custo habitacional, com finalidade de substituição de moradia, usualmente consideram apenas os custos do imóvel, imaginando-se que a família já esteja pagando pelos serviços públicos que consomem e isto é verdadeiro 
apenas para o gás (tabela 27) ${ }^{122}$. Ao se mudarem para um conjunto habitacional, recebem este encargo adicional" que deve compor, portanto, o valor do custo habitacional.

Tabela 27 - Percentual de pagantes pelos serviços públicos

\begin{tabular}{|l|c|c|c|}
\hline Serviço Público & Paga (\%) & Não Paga (\%) & Total (\%) \\
\hline água & 51,0 & 49,0 & 100,0 \\
\hline eletricidade & 70,3 & 29,7 & 100,0 \\
\hline gás & 95,7 & 4,3 & 100,0 \\
\hline
\end{tabular}

(Fonte: CDHU/FIA, 2002)

O custo habitacional ${ }^{123}$, conforme demonstrado na tabela 28 , é bastante significativo apresentando valores de até $10 \%$ da renda para $64 \%$ das famílias, de até $30 \%$ para $87 \%$ e de até $40 \%$ para $93 \%$ das famílias. Observa-se também que as famílias de renda mais baixa tendem a ter custo habitacional mais elevado.

Tabela 28 - Comprometimento de renda com custos habitacionais

\begin{tabular}{|l|c|c|c|c|c|c|c|c|}
\hline \multirow{2}{*}{$\begin{array}{l}\text { Renda } \\
(\mathrm{sm})\end{array}$} & \multicolumn{7}{|c|}{ Comprometimento de renda (\%) } & \multirow{2}{*}{ Total (\%) } \\
\cline { 2 - 9 } & até 10 & 10 a 20 & 20 a 30 & 30 a 40 & 40 a 50 & 50 a 60 & mais de 60 & \\
\hline 0 a 1 & 48,5 & 17,8 & 9,0 & 5,7 & 3,3 & 1,6 & 14,1 & 100,0 \\
\hline 1 a 3 & 62,1 & 13,3 & 6,1 & 5,8 & 4,9 & 3,2 & 4,6 & 100,0 \\
\hline 3 a 6 & 63,6 & 12,9 & 8,5 & 7,5 & 3,4 & 1,6 & 2,5 & 100,0 \\
\hline 6 a 10 & 61,7 & 15,6 & 9,2 & 6,6 & 2,4 & 1,6 & 2,9 & 100,0 \\
\hline acima 10 & 69,2 & 19,0 & 8,6 & 2,0 & 0,8 & 0,1 & 0,2 & 100,0 \\
\hline total & 63,5 & 14,9 & 8,3 & 5,9 & 2,9 & 1,6 & 2,9 & 100,0 \\
\hline
\end{tabular}

(Fonte: CDHU/FIA, 2002)

\footnotetext{
${ }^{122}$ Uma porcentagem expressiva de famílias de baixa renda não paga água ou eletricidade, recebendoas gratuitamente do poder público, através de subsídios integrais, o que não ocorre com o gás.

${ }^{123}$ Não há dados específicos para o universo da população beneficiária da CDHU como aferido para os demais itens, mas por entender que os custos habitacionais incidentes sobre a população de baixa renda seja uma variável apreciável, apresenta-se a seguir, os resultados do trabalho elaborado pela CDHU/FIA em 2002, entitulado "Delineamento de cenário e revisão da política habitacional do estado de São Paulo".
} 


\subsubsection{Perfil Educacional}

O perfil educacional (tabela 29) indica que o segmento populacional acima de 35 anos caracteriza-se por um baixo nível de instrução. Essa situação inverte-se com a redução da faixa etária significando a melhora no nível de instrução entre os mais jovens $^{124}$. Observa-se ao mesmo tempo, o atraso escolar caracterizado pela alta incidência de jovens entre 15 e 17 anos ainda na faixa de $1^{\circ}$ grau incompleto ou completo. Esta tendência ressalta a dificuldade por parte destes, de concluir o $1^{\circ}$ grau dentro do período previsto, expressando o baixo desempenho escolar.

Levantamento para verificar a necessidade de promover a adaptação dos novos moradores à vida compartilhada, característica de moradias verticais, indicou que quase $80 \%$ da população beneficiária não possuía experiência em morar em apartamentos, exigindo o desenvolvimento de mecanismos de adequação à vida condominial $^{125}$.

Tabela 29 - Perfil educacional da população atendida pela CDHU

\begin{tabular}{|l|c|c|c|c|c|c|c|}
\hline \multirow{2}{*}{ Instrução adquirida } & \multicolumn{7}{|c|}{ Faixa Etária (anos) } \\
\cline { 2 - 8 } & total & 7 a 10 & 11 a 14 & 15 a 17 & 18 a 24 & 25 a 35 & $\begin{array}{c}36 \text { ou } \\
\text { mais }\end{array}$ \\
\hline sem instrução & 4,3 & $(1)$ & $(1)$ & $(1)$ & $(1)$ & 2,9 & 12,7 \\
\hline $\begin{array}{l}\text { primário } \\
\text { (incompleto/completo) }\end{array}$ & 34,0 & 96,1 & 36,5 & 12,3 & 14,0 & 21,9 & 43,4 \\
\hline $1^{\circ}$ grau incompleto & 24,2 & $(1)$ & 58,0 & 36,8 & 26,4 & 25,5 & 14,8 \\
\hline $1^{\circ}$ grau completo & 13,0 & 0,0 & $(1)$ & 19,2 & 17,5 & 17,7 & 11,3 \\
\hline $2^{\circ}$ grau incompleto & 9,6 & 0,0 & $(1)$ & 25,9 & 18,4 & 10,4 & 4,1 \\
\hline $2^{\circ}$ grau completo & 11,8 & 0,0 & 0,0 & $(1)$ & 19,6 & 18,1 & 9,2 \\
\hline ensino superior & 1,1 & 0,0 & 0,0 & $(1)$ & $(1)$ & 1,9 & $(1)$ \\
\hline Total & 100 & 100 & 100 & 100 & 100 & 100 & 100 \\
\hline
\end{tabular}

(Fonte: CDHU/SEADE, 1998)

(1) a amostra não comporta a desagregação para esta categoria

\footnotetext{
${ }^{124}$.Resultado da política de universalização do ensino de $1^{\circ}$ grau.

125 Esta informação ilustrar os hábitos da população beneficiária quanto ao convívio mútuo e ao gerenciamento de espaços comuns, características estas favoráveis ao bom funcionamento dos sistemas de drenagem.
} 


\subsection{Filosofia dos Sistemas de Drenagem da CDHU}

Os sistemas de drenagem da CDHU procuram garantir a segurança dos empreendimentos de forma simples, eficiente e a custo mais baixo possível, para não encarecer os empreendimentos e facilitar as condições de financiamentos, assim como respeitar as condições sociais e econômicas da população alvo quanto à capacidade de conservação dos sistemas propostos.

Desta forma, os projetos de drenagem seguem as prerrogativas e critérios aceitos pelo meio técnico, ao mesmo tempo em que zela pelo atendimento às legislações vigentes, procurando sempre otimizar as soluções e adequá-las aos futuros moradores e ao meio ambiente. Esses projetos também se preocupam com a observância das condições de execução, manutenção e operação dos sistemas, de acordo com as características dos responsáveis por cada item.

Seguindo estes preceitos, evita-se soluções que requeiram a execução de sistemas subterrâneos (ralos, galerias, etc.), privilegiado sistemas superficiais (canaletas, rápidos, etc.) devido à possibilidade de visualização de obstruções, facilidade de acesso e simplicidade de manutenção, assim como evita-se a instalação de equipamentos elétricos, que fatalmente se traduzem em aumento de custos dos condomínios e necessidade de mão de obra especializada para manutenções periódicas. 


\section{ESTUDOS DE CASOS}

Ainda são incipientes os conjuntos habitacionais da CDHU que contam com reservatórios de detenção. Entretanto, faz-se necessária uma ponderação sobre estas estruturas na medida em que seu uso se torna mais freqüente e, preponderantemente, devido às muitas interferências na concepção e elaboração de projetos, assim como na operação e manutenção dos sistemas de drenagem, principalmente em consideração à camada da população atendida.

Para este trabalho, foram selecionados 5 empreendimentos, cada um com suas características particulares. O primeiro, denominado Conjunto Habitacional Itaquera C3, foi um dos pioneiros da CDHU na utilização de reservatórios de detenção, sendo estes concebidos e implantados após a ocupação do conjunto. O segundo, chamado de Conjunto Habitacional Jaraguá $H$, teve a implantação dos reservatórios de detenção determinada por lei, durante a elaboração do projeto de drenagem, quando foi promulgada a "Lei das Piscininhas" pelo município de São Paulo. O terceiro, conhecido como Conjunto Habitacional Vila Jacuí B1, ainda está em fase de elaboração, porém devido às características peculiares da solução encontrada, está sendo incluído neste estudo de casos. O quarto, trata-se de uma experiência "difícil" e, para resguardar o município e profissionais envolvidos, será denominado apenas de Conjunto Habitacional A. O quinto e último, chamado de Conjunto Habitacional Herculândia C, também não tem seu projeto totalmente concluído, entretanto é o único dentre os empreendimentos selecionados cujo reservatório de detenção será incorporado e utilizado como área de recreação. 


\subsection{Conjunto Habitacional Itaquera C3}

Apesar de localizado no município de São Paulo, a implantação dos reservatórios de detenção no Conjunto Habitacional Itaquera C3, antecede a promulgação da lei que obriga empreendimentos neste município a adotarem sistemas de armazenamento de águas pluviais em lotes com área impermeabilizada superior a $500 \mathrm{~m}^{2}$.

Esses reservatórios de detenção foram viabilizados a partir da solicitação de um dos representantes da comunidade local, um religioso que cuida do bem estar da população mais carente da região, preocupado com a situação dos habitantes de uma ocupação irregular mais à jusante do empreendimento da CDHU, que ocupa o talvegue onde é feito o lançamento do sistema de drenagem das proximidades.

Nessa ocasião, o conjunto já estava entregue e habitado, e por isso, as premissas básicas adotadas para elaboração do projeto foram a manutenção das vazões a níveis existentes antes da urbanização, de forma a simular as condições naturais do terreno, e a minimização de interferências na vida dos condôminos.

Alternativas de infiltração foram descartadas em função da área livre existente ser parte de um talude e portanto, não recomendável para este tipo de solução e também porque a área disponível era suficiente para atender as premissas básicas adotadas por meio de reservatórios de detenção.

Análises das bacias contribuintes e das áreas disponíveis para implantação dos reservatórios de detenção levaram à preservação do sistema já existente e à utilização do talude pertencente ao recuo dos prédios para implantação das estruturas.

Para escolha desta alternativa, foi considerado que a bacia de contribuição, formada exclusivamente por áreas internas ao empreendimento, constituía-se num elemento cujas características eram conhecidas e estáveis, com qualidade do escoamento superficial condizente com a ocupação e passível de controle, não representando grandes preocupações para elaboração dos projetos.

O dimensionamento dos reservatórios foi realizado através do método simplificado proposto por McCuen (TUCCI, PORTO e BARROS, 1995), 
considerando os hidrogramas de entrada antes e depois da urbanização, por tratar-se de área de pequena dimensão.

Foram adotados então, reservatórios cilíndricos em anéis pré-moldados de concreto e cobertos, com número de unidades de acordo com as necessidades de reservação de cada sub-bacia estudada (figura 45). Para interligação dos reservatórios nos casos em que o diâmetro da tubulação de saída resultou muito pequeno e pouco recomendado ou na necessidade de um volume maior de armazenamento, foram previstos tubos de PVC que proporcionariam o funcionamento do sistema como vasos comunicantes, mantendo o mesmo nível em cada uma das unidades.

Os dispositivos de entrada e extravasão foram aproveitados do sistema de drenagem existente e, portanto, já estavam pré-dimensionados conforme técnica corrente para obras de microdrenagem, e com parâmetros compatíveis com aqueles utilizados para determinação dos hidrogramas.

Caixas coletoras foram instaladas nos sistemas de canaletas existentes e no final dos estacionamentos, para desvio das águas pluviais aos reservatórios.

Os dispositivos de saída foram dimensionados como orifícios, de acordo com a vazão máxima pré-estabelecida, representando elementos independentes de intervenções humanas para operação e, desta maneira, constituindo-se num sistema de operação autônomo.

Para minimizar problemas com resíduos sólidos foram solicitados a proteção dos dispositivos de entrada e saída, o plantio de grama nas áreas livres, a garantia de acesso ao interior do reservatório e a manutenção periódica de todo o sistema.

O sistema proposto e os materiais utilizados foram propositadamente selecionados para agilizar a execução, restringindo a escolha aos produtos e dimensões facilmente encontrados no mercado (figura 46).

A grande peculiaridade da implantação destes reservatórios de detenção, além terem sido implantados após a ocupação do conjunto, foi sua forma de solicitação e a aceitação pelos moradores do conjunto habitacional, que não foram diretamente beneficiados. Este fato só foi possível devido à grande influência do representante da comunidade local, responsável por toda a gestão junto aos mesmos. 


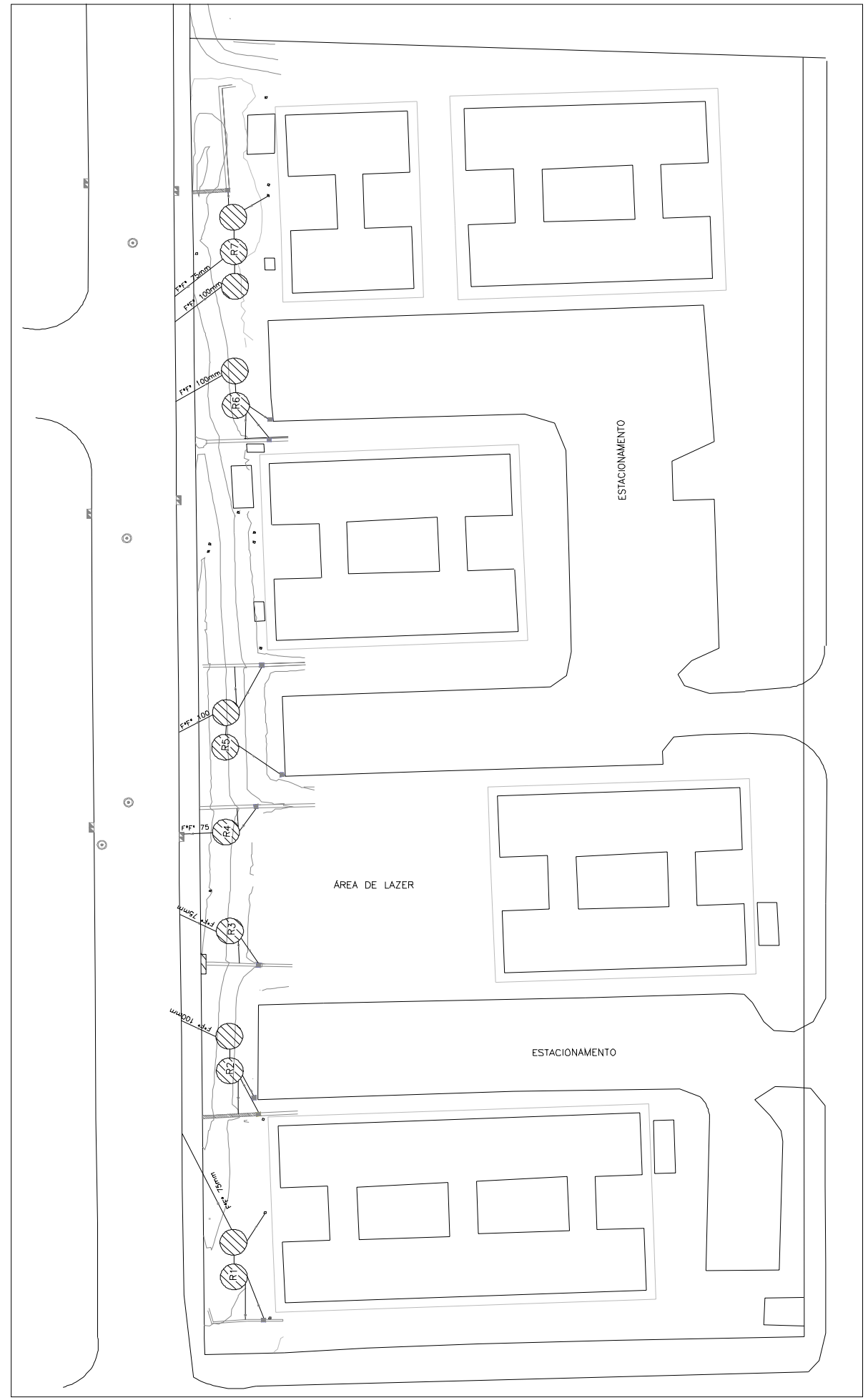

Figura 45 - Planta do Conjunto Habitacional Itaquera C3 


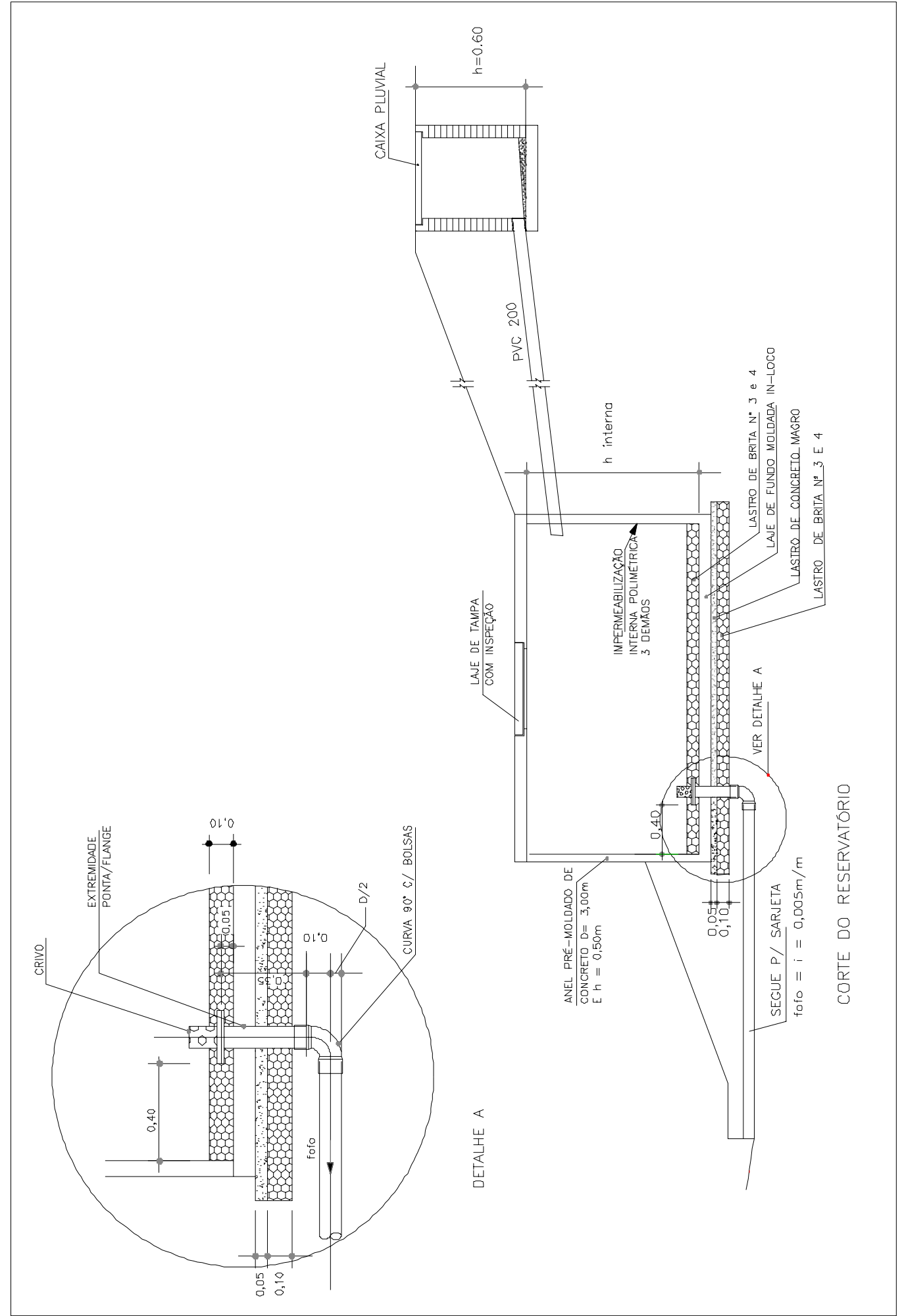

Figura 46 - Corte e detalhe genérico do reservatório de detenção 


\subsubsection{Estado atual}

Vistoria realizada encontrou todos os reservatórios de detenção completamente inoperantes e cheios.

Conforme ilustrado pelas figuras 47 e 48, observa-se que alguns estão totalmente obstruídos e outros, apesar de cheios, ainda permanecem com uma reduzida vazão, indicando que os dispositivos de saída estão em condições sofríveis, porém não totalmente obstruídos.

A figura 49, esclarece a obstrução dos dispositivos: o sistema de drenagem periférico coleta e conduz todos os resíduos sólidos, não devidamente destinados, diretamente para o interior dos reservatórios.

Observa-se que o conjunto conta com coleta regular de lixo, não havendo motivos para encontrar sacos de lixo nos dispositivos de drenagem. Indagados sobre o problema, os moradores simplesmente disseram que não havia como controlar "as crianças".

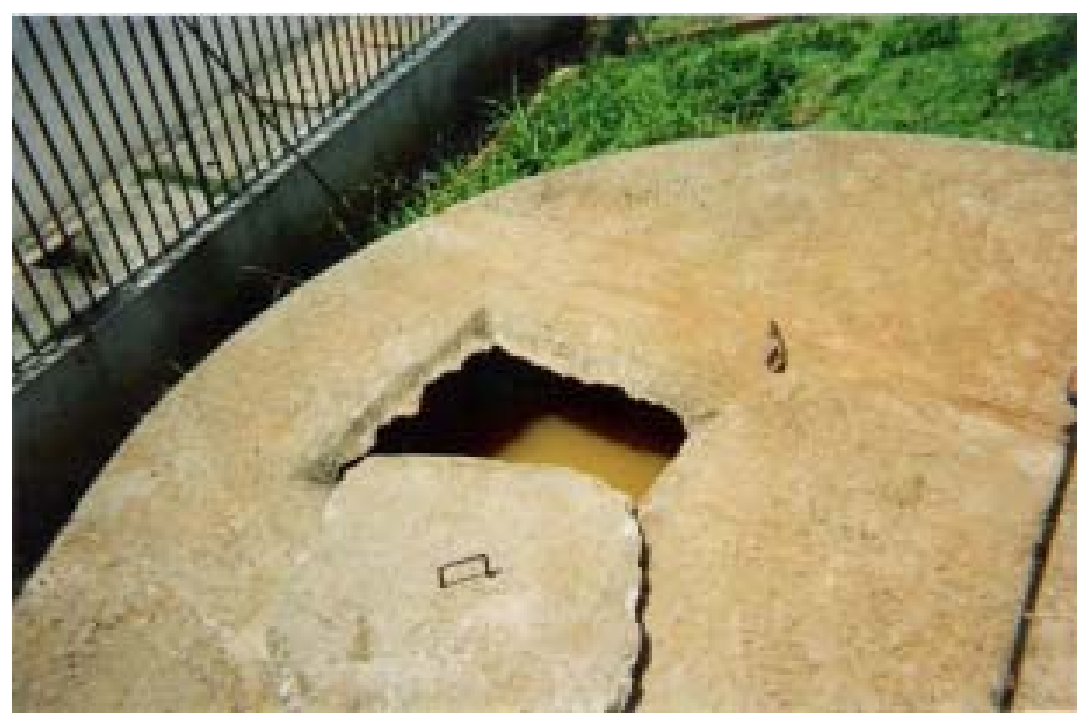

Figura 47 - Reservatório completamente cheio 


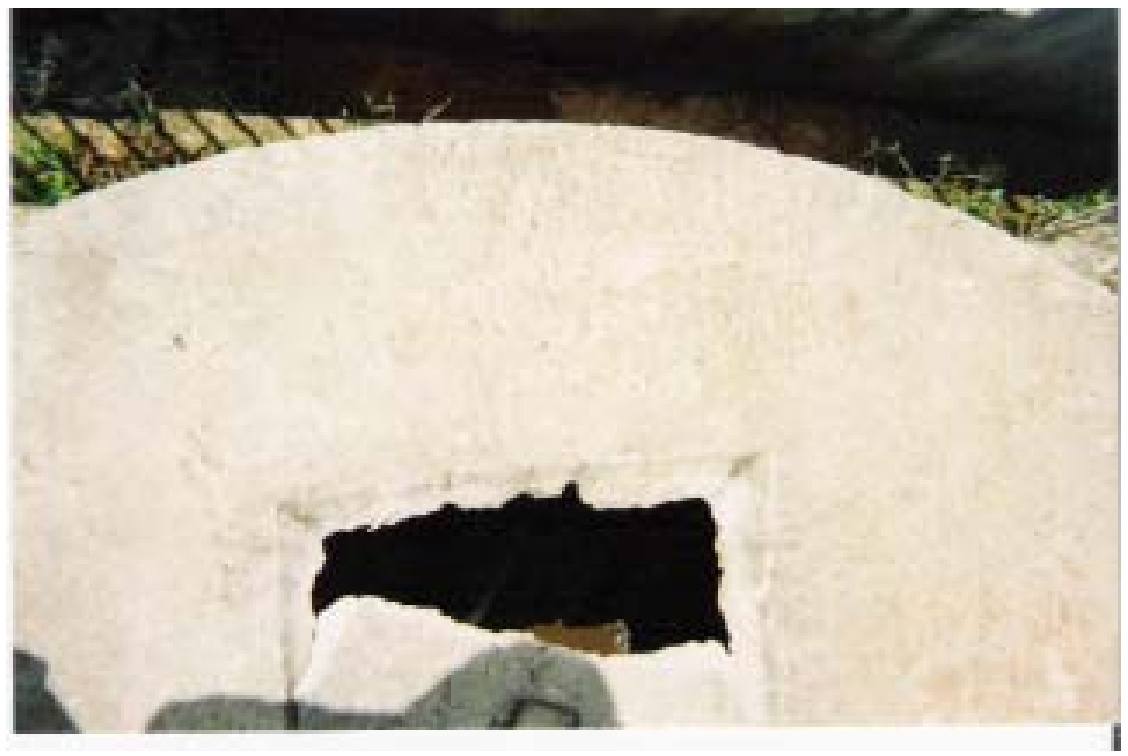

Figura 48 - Reservatório parcialmente cheio

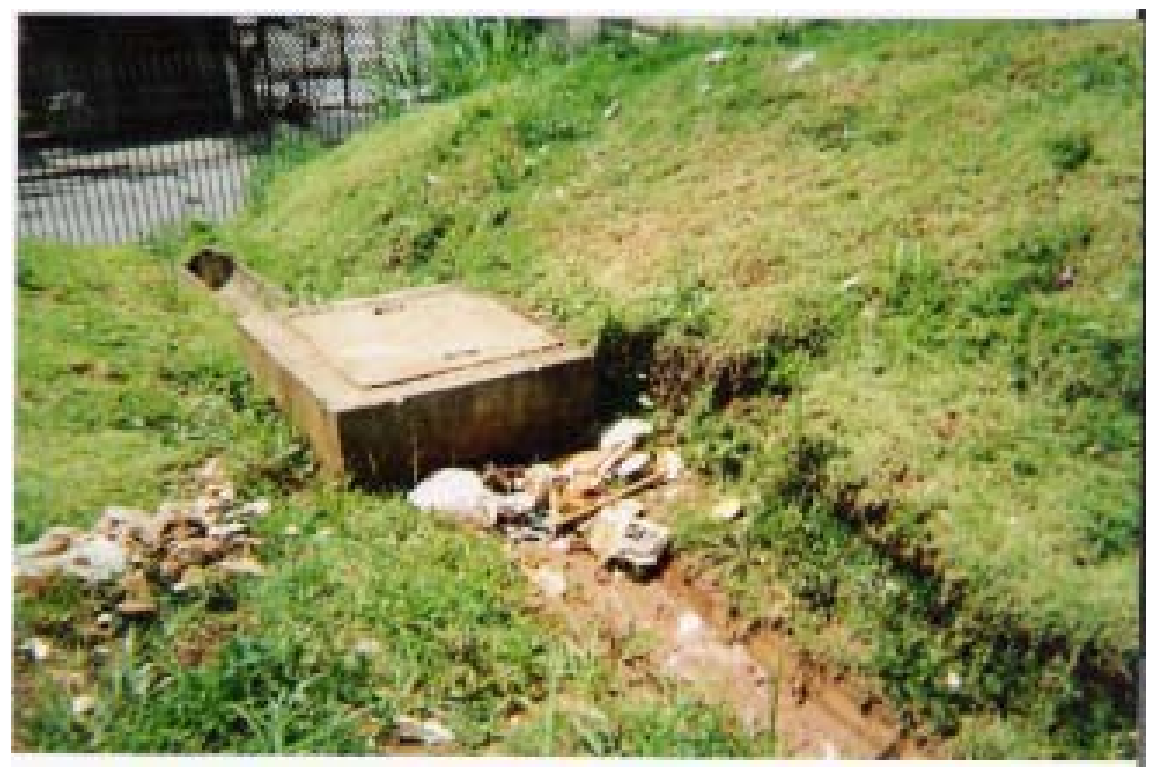

Figura 49 - Motivo da obstrução dos dispositivos 
Outro fato observado, além da tampa de acesso quebrada da figura 48, é o caimento da tubulação de extravasão que está em sentido inverso ao projetado (figura 50), indicando que existem também problemas de execução.

A abertura de acesso muito estreita é pouco conveniente para operações de manutenção, podendo ser melhorada nos próximos projetos. Porém deve-se manter uma certa "dificuldade" para que não seja convidativa para outras finalidades ilícitas.

Infelizmente, devido às condições atuais dos reservatórios, não será possível analisar os parâmetros de cálculo e o desempenho de cada um dos sistemas e suas partes constituintes, conforme esperado.

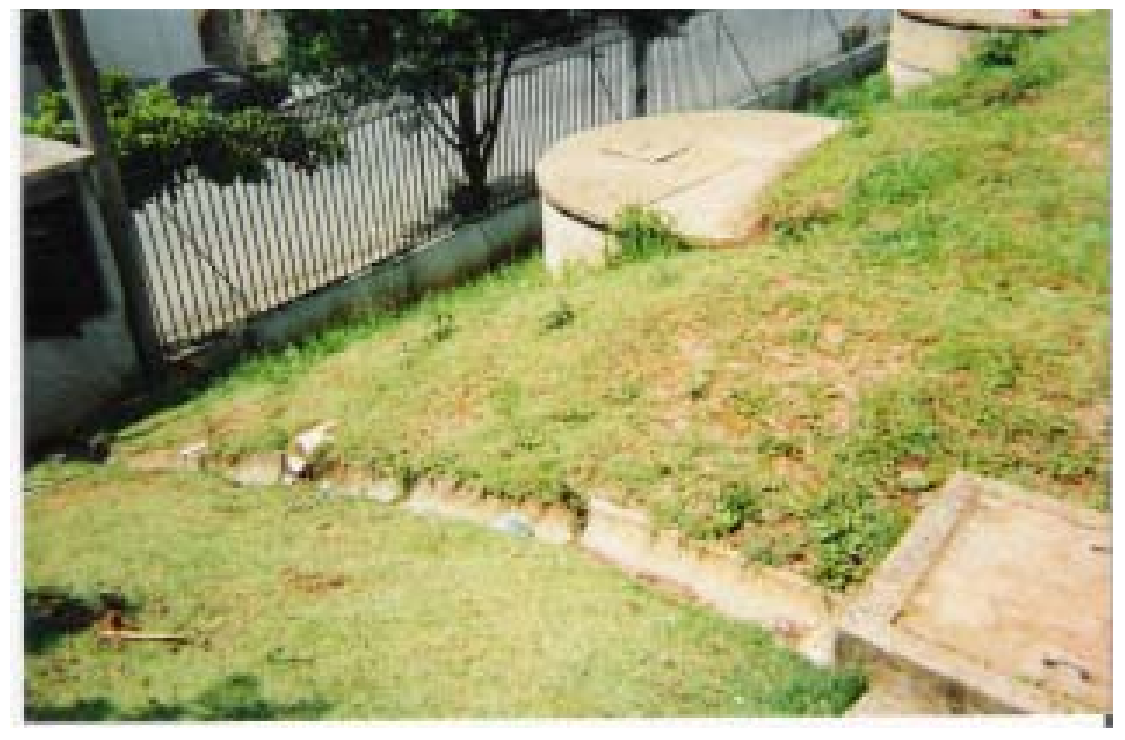

Figura 50 - Extravasor com caimento invertido

Fotos gentilmente cedidas pelo departamento de obras da CDHU, ilustram a execução dos reservatórios de detenção e das caixas coletoras (figura 51), e demonstram que o sistema proposto, apesar das preocupações pré-existentes, interferiram na vida condominial (figura 52). 

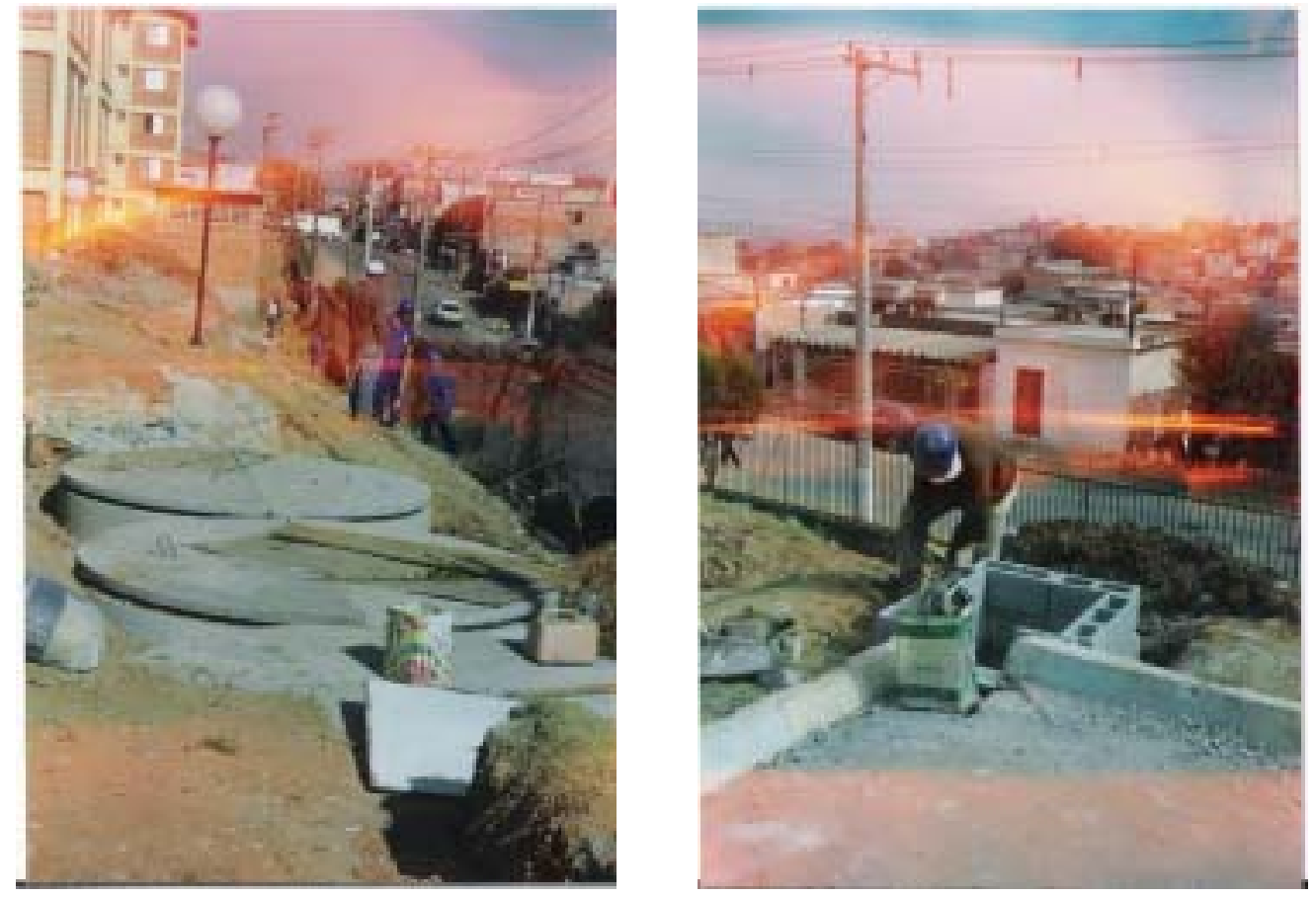

Figura 51 - Execução dos reservatórios de detenção e das caixas coletoras Fonte: Departamento de Obras da CDHU (2002)
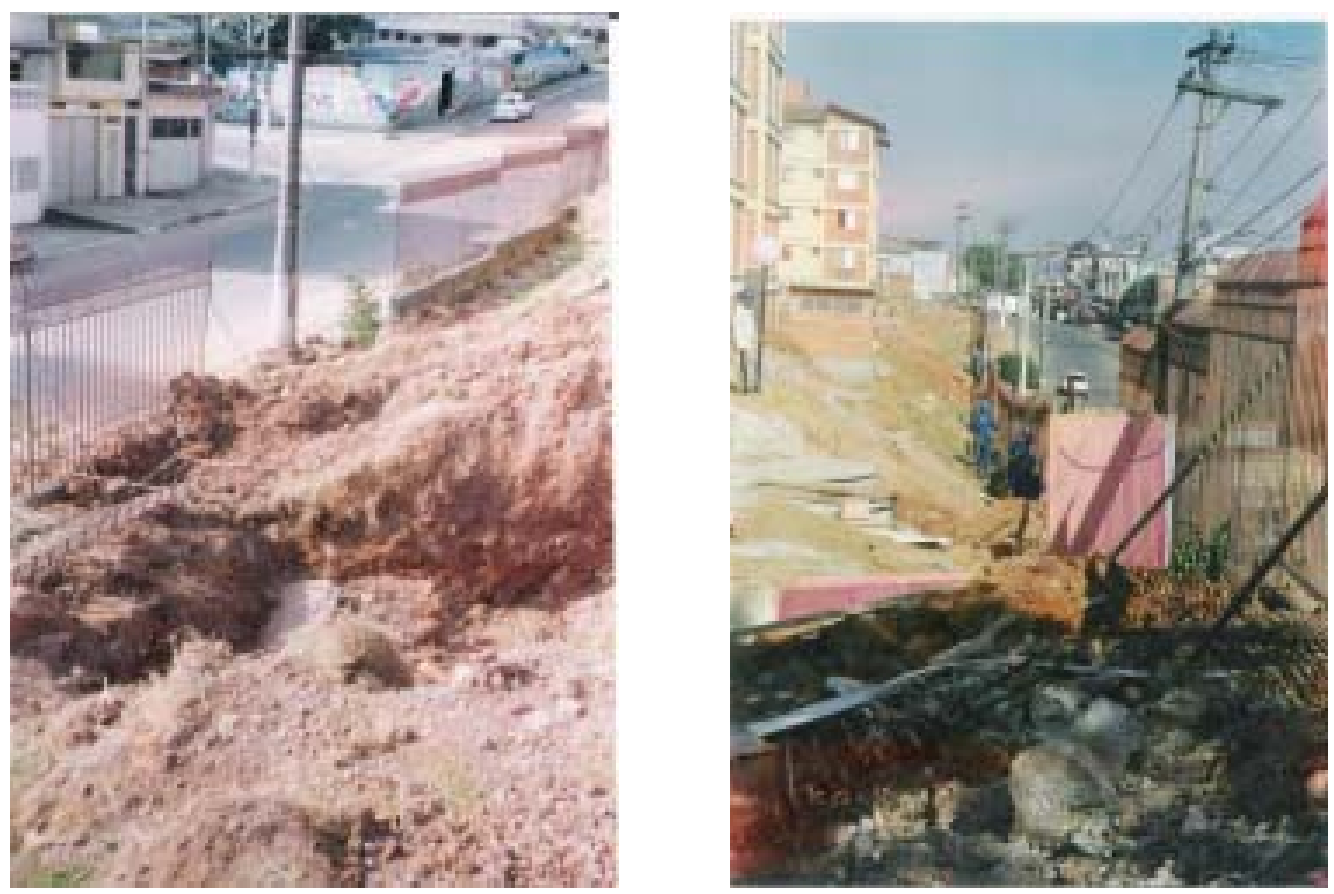

Figura 52 - Remoção e recolocação das cercas do empreendimento Fonte: Departamento de Obras da CDHU (2002) 
Segundo os moradores, os reservatórios de detenção demandam manutenção constante e mesmo assim, voltam a permanecer cheios. Isso significa que a produção de resíduos sólidos é bastante grande e não há manutenção adequada no condomínio que possibilite a coleta destes materiais, antes do seu encaminhamento para os dispositivos de drenagem.

Os gradeamentos instalados nas entradas dos sistemas retêm parte dos resíduos, porém não são suficientes. Orientações sobre formas de prevenção e redução do aporte de resíduos aos reservatórios, para diminuir a periodicidade das manutenções, fazem-se urgentemente necessários. E é preciso averiguar também as condições de operação dos dispositivos de saída e das tubulações que fazem as interligações entre os reservatórios.

Pelo exposto, o sistema de drenagem a jusante do empreendimento está sendo bastante favorecido com o aumento da qualidade da água proveniente do conjunto e demonstra que, apesar desta não ser a finalidade principal dos reservatórios de detenção, estes cumprem parcialmente esta missão.

A suposição feita durante a elaboração do projeto de que, por tratar-se apenas de contribuição interna do empreendimento, não haveria grandes problemas com a geração de resíduos, não se consolidou perante os maus hábitos dos moradores. Não se sabe se esses hábitos já existiam ou se foram gerados pela implantação dos reservatórios e a possibilidade de ocultação desse comportamento.

Os moradores também afirmaram que antes da instalação dos reservatórios não havia esse tipo de problema e que toda a água escorria, naturalmente, pelo sistema de drenagem existente até o sistema viário. Essa afirmação demonstra que eles não estão suficientemente informados sobre a função dos reservatórios de detenção e que provavelmente não esperam arcar com a responsabilidade e os custos de manutenção ${ }^{126}$.

Não ficou claro se os moradores já se encarregaram da manutenção dos reservatórios ou não. O que se sabe é que o problema já ocorreu anteriormente. Adicionalmente, a CDHU não possui uma avaliação regular de pós-ocupação dos

\footnotetext{
${ }^{126}$ É comum nos conjuntos da CDHU, a população não compreender que a manutenção condominial e predial, como por exemplo a limpeza das caixas d'água, não são de responsabilidade da companhia, mas sim dos próprios moradores, como acontece em qualquer outro empreendimento.
} 
conjuntos, o que dificulta o acompanhamento do desempenho dos dispositivos e o aprimoramento dos projetos.

Outra constatação é que a influência do representante da comunidade local não foi suficiente para garantir a continuidade da proposta inicial e, portanto, seus objetivos não estão sendo alcançados. Neste caso, a cessão do espaço não significou o comprometimento com a finalidade e muito menos a aceitação do ônus de sua manutenção. Faltou envolvimento maior dos moradores durante todo o processo, o que poderia traduzir-se na participação e colaboração mais efetiva, ou até mesmo na adoção de outras alternativas.

Apesar do acima exposto, existem duas características positivas com relação à implantação destes reservatórios de detenção: o impacto visual e a integração com o ambiente.

No contexto ambiental, os edifícios e sua volumetria tornaram os reservatórios de detenção menos visíveis, conforme ilustra a figura 53. Soma-se a isso, o fato de estarem parcialmente ocultos pelos taludes e encobertos pelos gramados e jardins, nas partes mais amenas do terreno (figuras 54, 55 e 56).

Assim os reservatórios, apesar de suas consideráveis dimensões, não se constituíram em elementos visualmente agressivos, sendo harmoniosamente incorporados ao meio ambiente e com possibilidades de serem melhor aceitos pelos urbanistas.

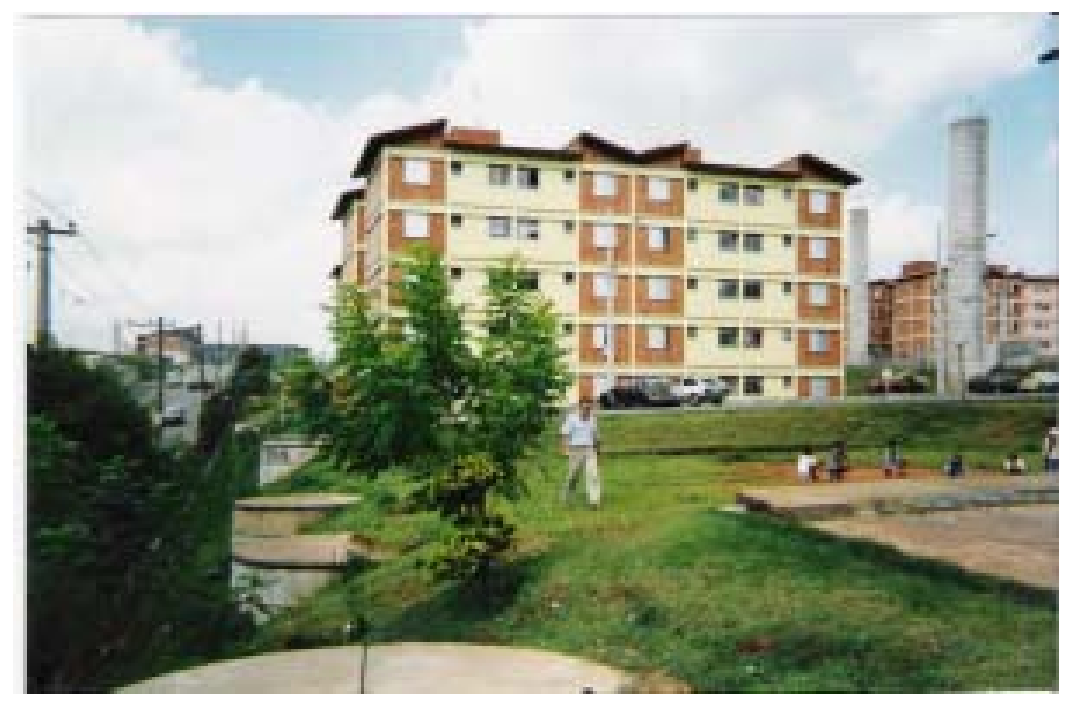

Figura 53 - Impacto visual dos reservatórios no contexto ambiental interno 


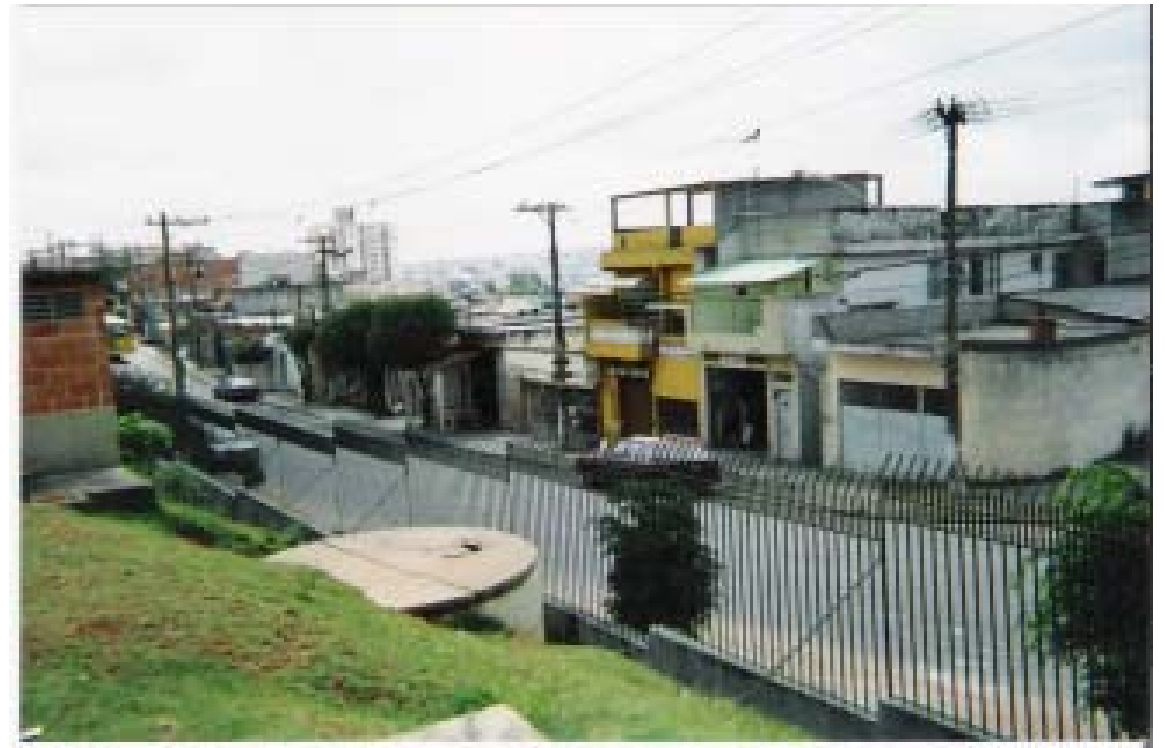

Figura 54 - Impacto visual dos reservatórios no contexto ambiental externo

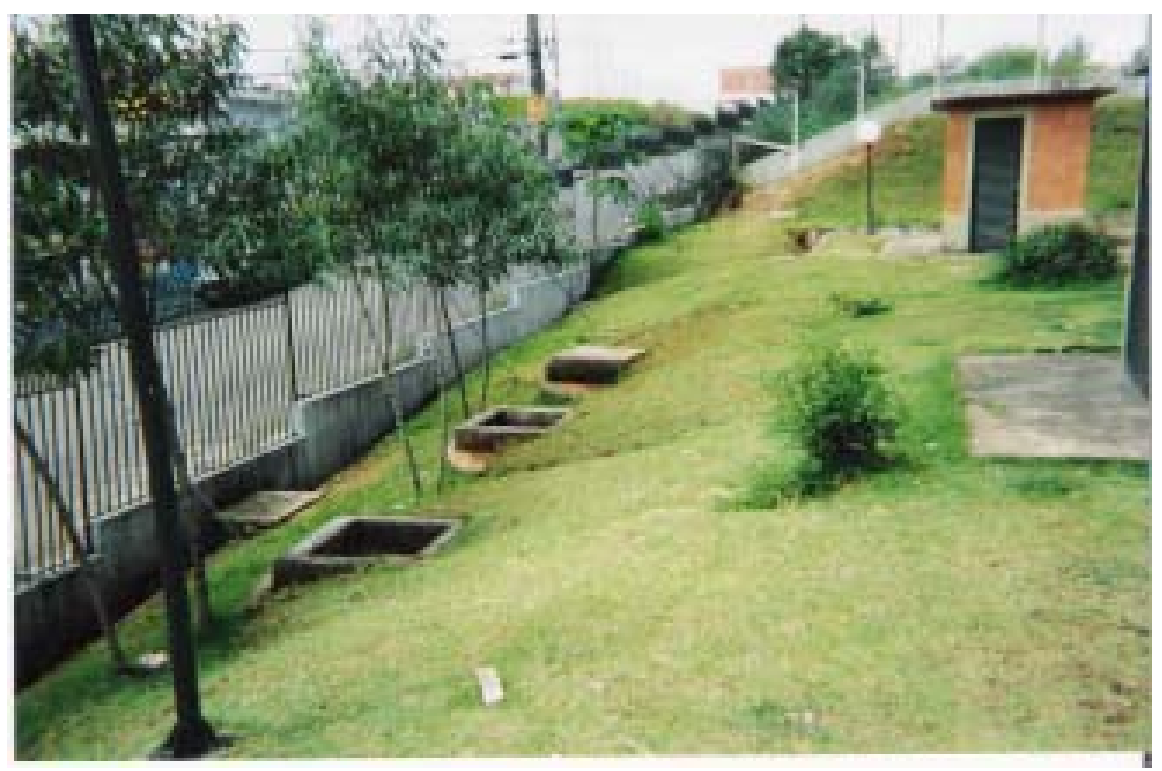

Figura 55 - Reservatórios ocultos pelos taludes 


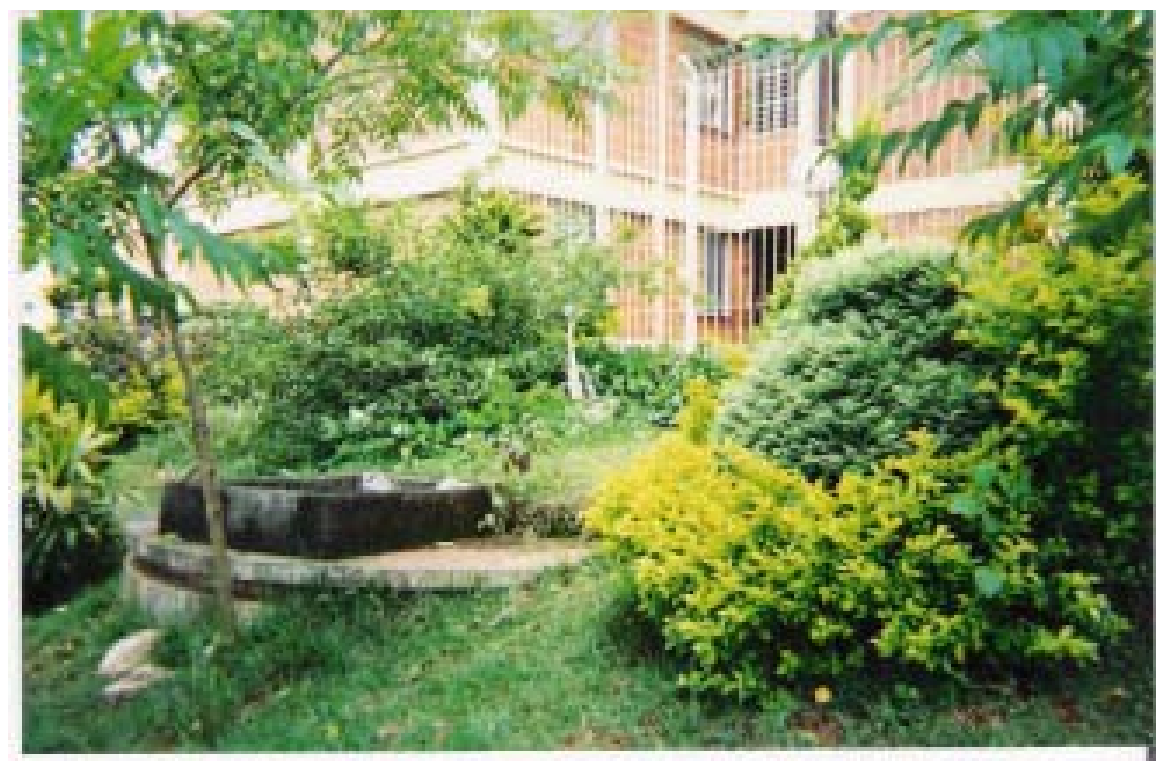

Figura 56 Reservatórios envolvidos pela vegetação

\subsection{Conjunto Habitacional Jaraguá $\mathbf{H}$}

O Conjunto Habitacional Jaraguá H estava em fase final de projetos quando ocorreu a promulgação da legislação específica pelo município de São Paulo.

A primeira preocupação foi então, encontrar área disponível para implantação dos reservatórios, sem que houvesse necessidade de modificações significativas dos projetos já concluídos e de instalação de equipamentos elétricos, que se traduziriam em aumento das despesas de condomínio para os futuros moradores.

A lei promulgada em São Paulo requer o armazenamento de todo o escoamento superficial das áreas impermeáveis do lote pelo período de uma hora, inviabilizando a instalação de dispositivos de saída que funcionassem como orifícios e que pudessem operar autonomamente com vazões crescentes à medida que aumentasse a lâmina de água no interior do reservatório.

A instalação de bombas também seria complexa pois seu acionamento não poderia ser feito por simples bóias de controle de níveis, uma vez que esses níveis são aleatórios, dependendo da intensidade e duração das chuvas, não garantindo o 
armazenamento por 1 hora ou seu esvaziamento após esse período. Para utilização de bombas seria necessário instalar sensores de nível mínimo de água que acionariam um outro dispositivo responsável pelo controle do tempo e pelo início de operação das mesmas.

A solução mais simples encontrada pela equipe envolvida no projeto, foi aproveitar a pequena área existente entre a fachada dos prédios e o início dos estacionamentos, tirando proveito do desnível existente entre eles, e criar reservatórios de detenção em concreto, estreitos, alongados e fechados ${ }^{127}$, com operação manual através de registros de gaveta, tubulação para extravasamento instalada no limite máximo de armazenamento e acessos para inspeção e limpeza ao longo da estrutura (figura 57 e 58).

A tubulação de saída foi protegida para evitar possíveis entupimentos e a proliferação de insetos, e foi previsto também, declividade mínima de fundo, para evitar acúmulo de água ao longo do comprimento do reservatório.

Os volumes foram calculados conforme equação estabelecida pela referida Lei. Os dispositivos de saída dimensionados como orifícios e os extravasores como conduto livre pelo método racional.

A grande dúvida quanto à solução adotada era saber se o sistema funcionaria a contento, mesmo contando com operação manual, o que significaria depender de uma pessoa para abrir e fechar o registro depois de cada evento chuvoso. Porém entre criar gastos adicionais aos futuros moradores e contar com o entendimento e colaboração dos mesmos, optou-se por creditar confiança na boa vontade das pessoas, principalmente dos síndicos dos condomínios, adotando a solução proposta e criando uma pequena explanação sobre o sistema adotado e a forma de operação e manutenção. De qualquer maneira, sempre haveria a possibilidade de adaptação para automatizar os processos.

\footnotetext{
${ }^{127}$ Recorda-se que a legislação solicita que os reservatórios sejam fechados, cobertos e atendam às normas sanitárias vigentes.
} 


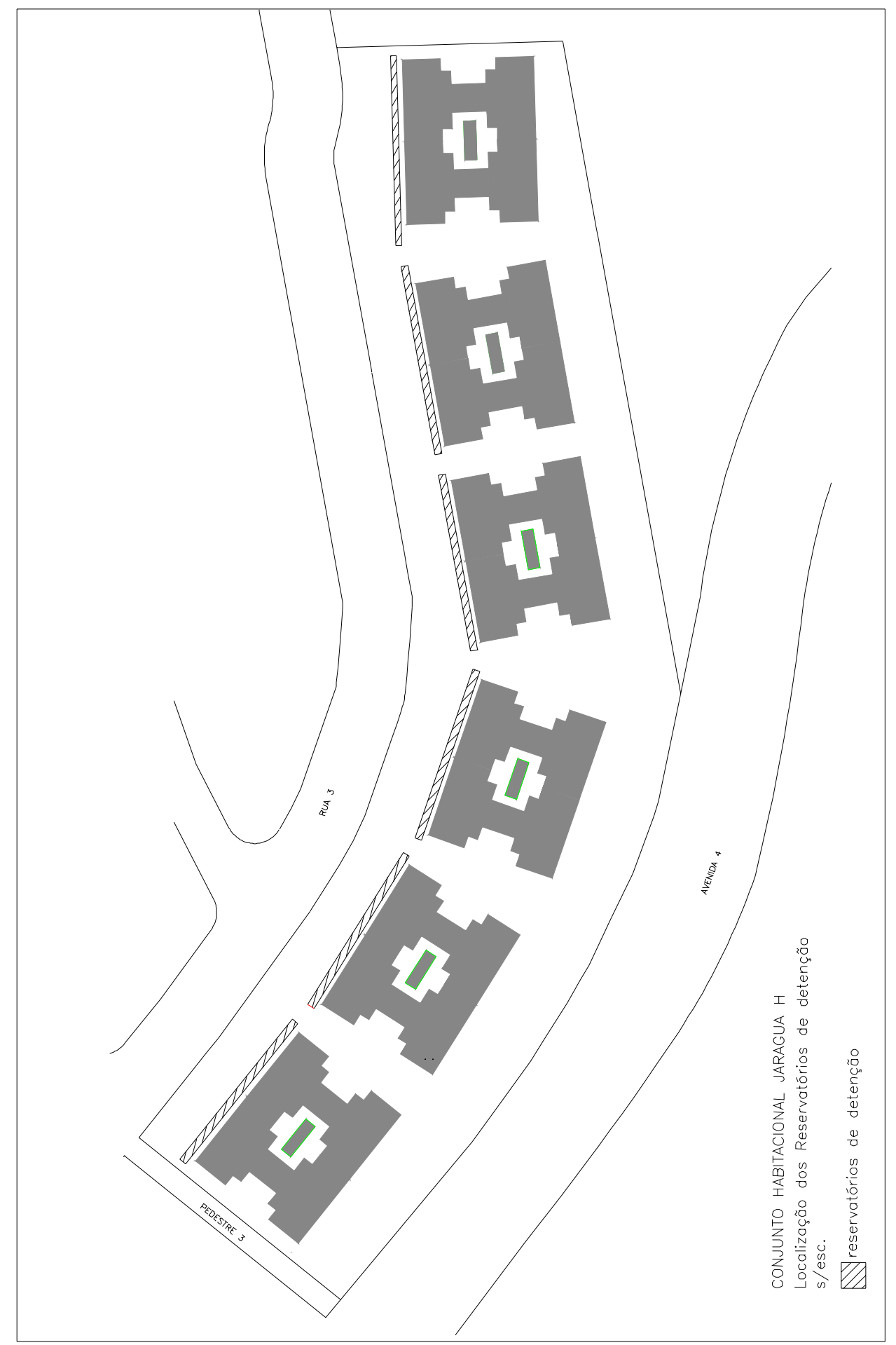

Figura 57 - Conjunto Habitacional Jaraguá H 


\section{DETALHE TÍPICO DOS RESERVATÓRIOS DE DETENÇÃO}

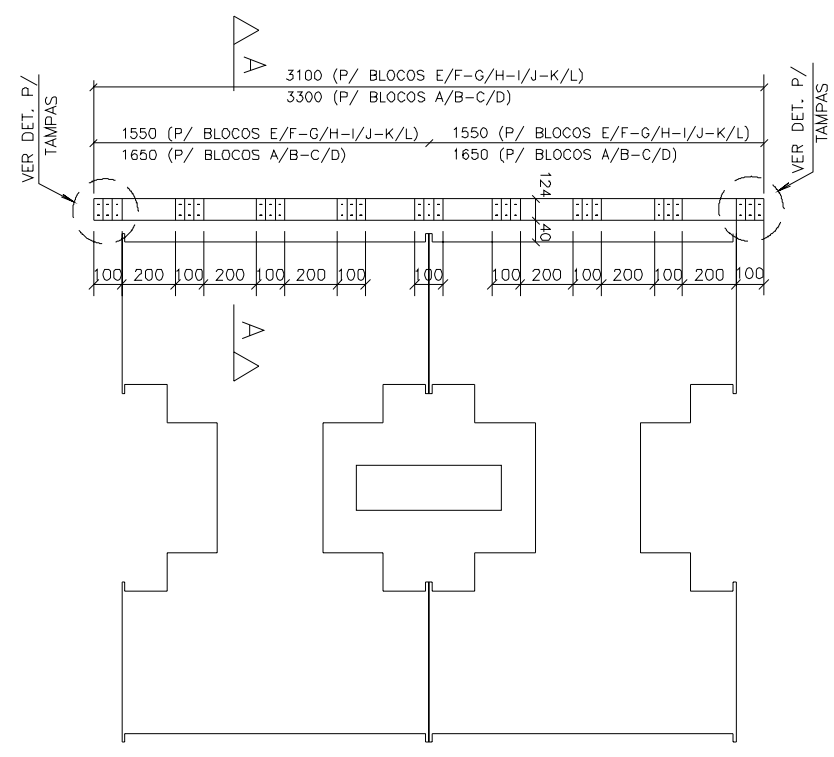

\section{ELEVAÇÃO TIPICA DOS RESERVATÓRIOS}
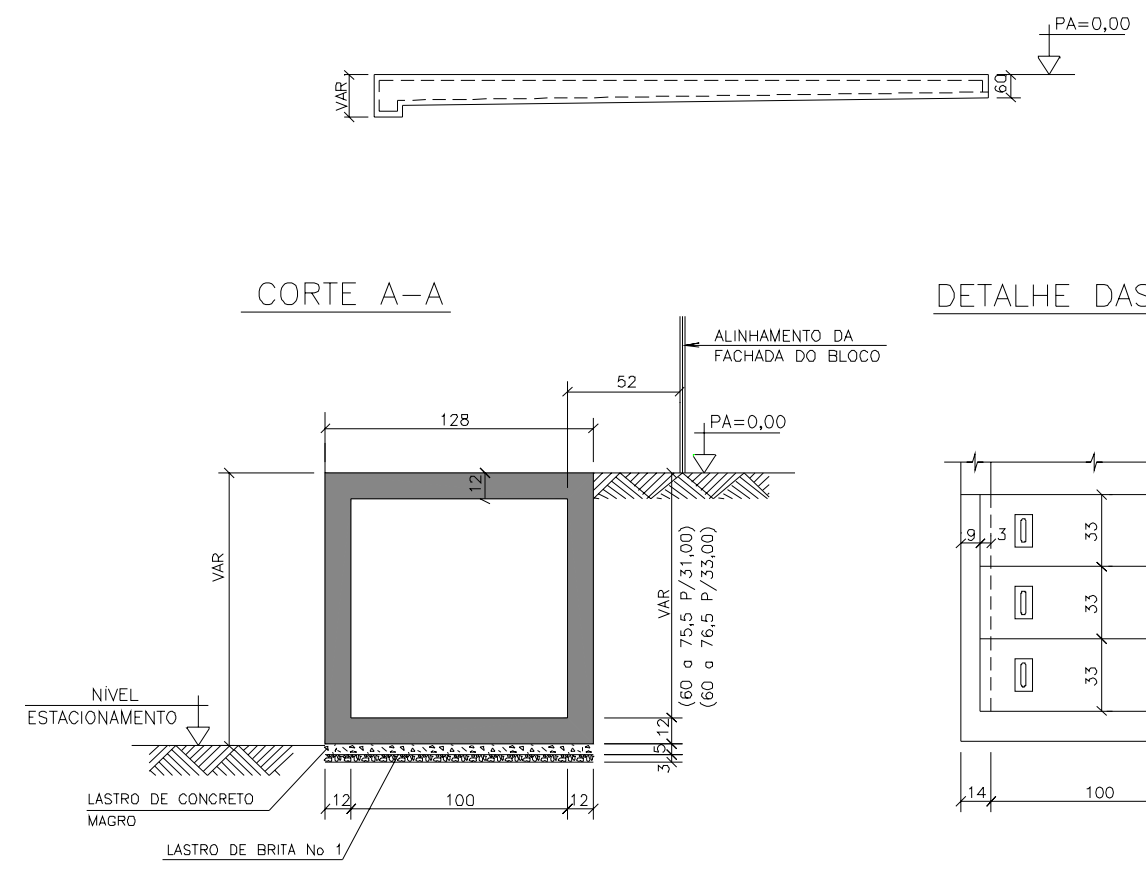

DETALHE DAS TAMPAS

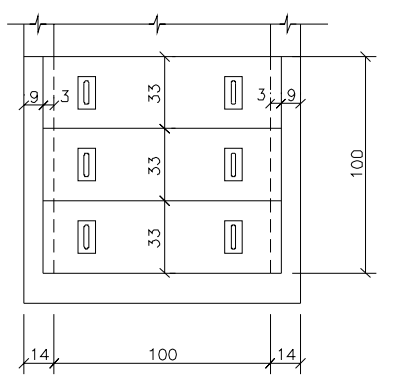

Figura 58 - Posicionamento e detalhamento dos reservatórios 


\subsubsection{Estado atual}

Os reservatórios de detenção implantados no conjunto habitacional Jaraguá $\mathrm{H}$, assim como aqueles do Itaquera C3, encontram-se inoperantes, apesar de estarem vazios ou parcialmente cheios, por vontade dos próprios moradores.

Neste caso, diferentemente do Itaquera C3, não há problemas de obstrução do sistema por resíduos sólidos pois os moradores zelam pela manutenção das condições de limpeza e higiene, inclusive dos sistemas de drenagem, como pode ser notado na figura 59. Observa-se também uma melhor organização dos moradores com relação às questões condominiais, atribuída segundo o mestre de obra responsável pelo conjunto, às relações anteriores existentes entre as famílias que hoje ocupam o empreendimento.
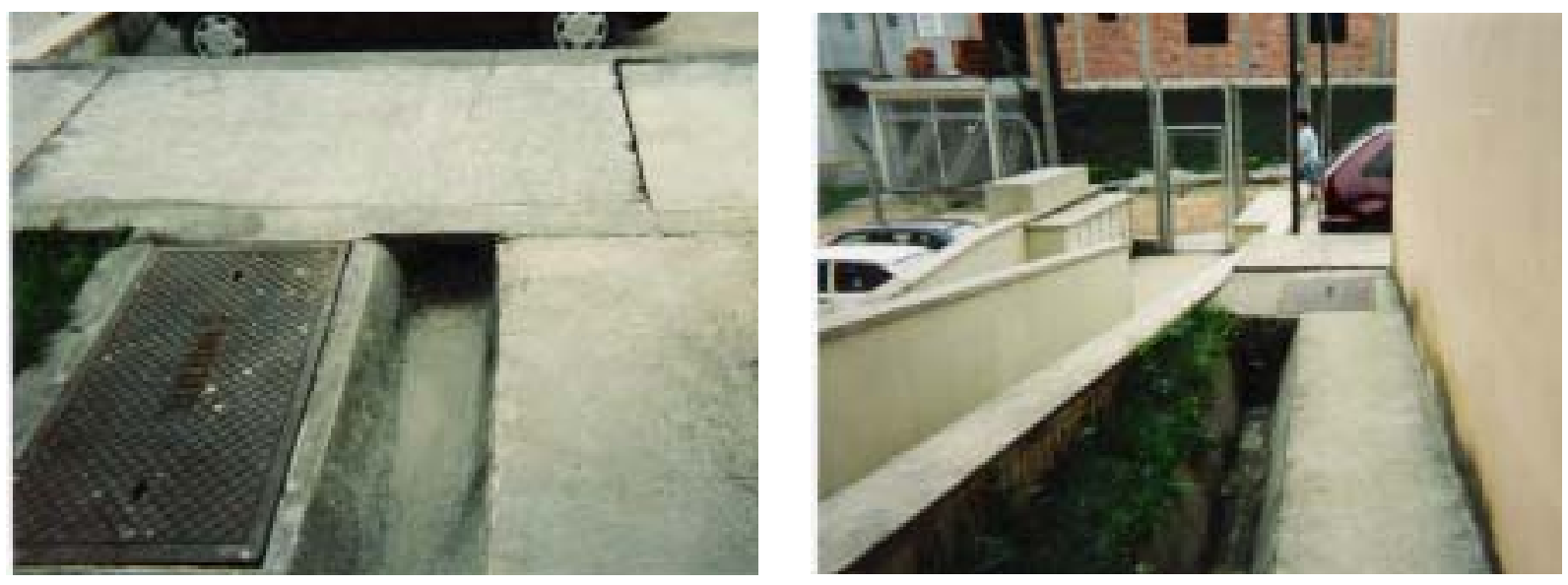

Figura 59 - Sistemas de drenagem conservados

A inoperância dos reservatórios é motivada por questões construtivas, associadas ao descumprimento do projeto de drenagem.

Questionados quanto às razões para não estarem operando adequadamente os reservatórios de detenção, a primeira justificativa foi a de que provocavam infiltrações nos apartamentos próximos a estes (figura 60). 


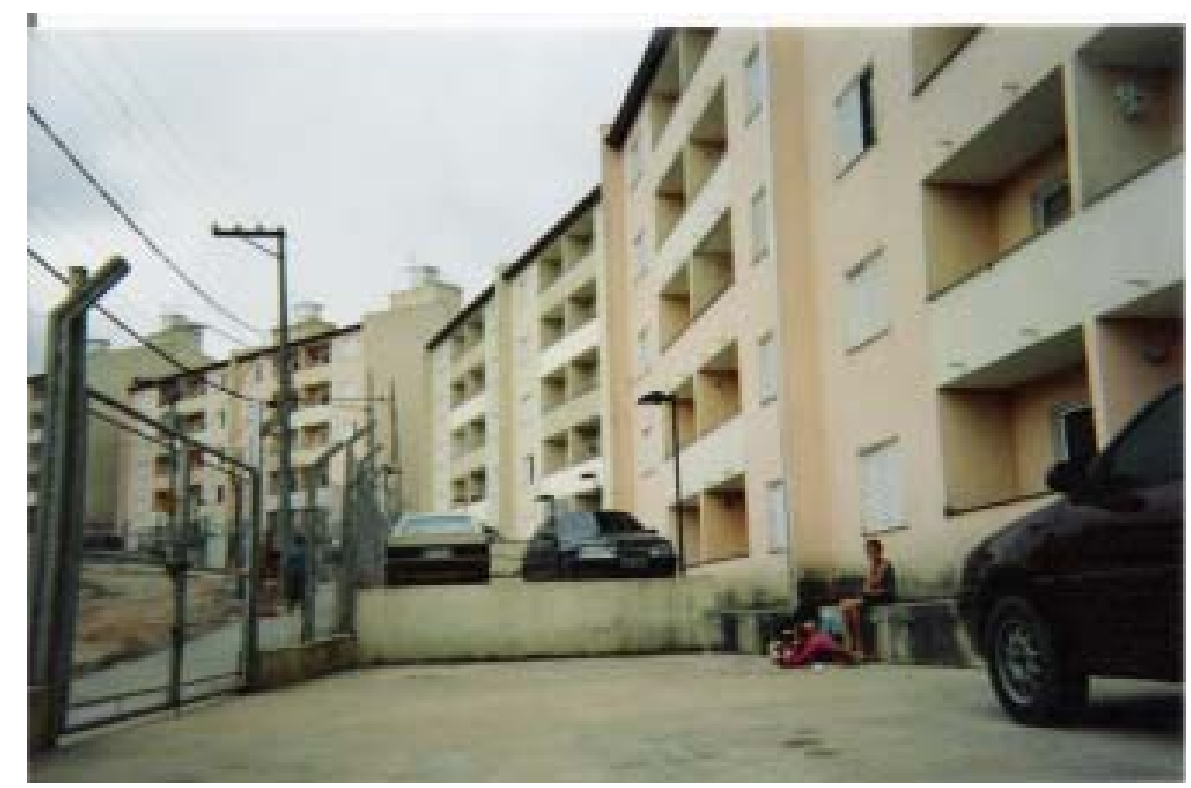

Figura 60 - Infiltrações nas paredes dos apartamentos e dos reservatórios

Observa-se que anteriormente à obrigatoriedade de implantação dos reservatórios, a área seria um gramado e este tipo de revestimento é permeável, não havendo portanto, modificações na condição original do projeto, o que indica problemas com a impermeabilização dos edifícios e talvez de caimento dos pisos. Outra observação com relação à impermeabilização é a estética das paredes dos reservatórios que ficam aparentes (figura 60).

A segunda justificativa, extremamente pertinente, é que o sistema transborda e durante a noite por exemplo, não há ninguém que se disponha a acompanhar o funcionamento dos reservatórios. A principal razão para esta ocorrência, que poderia também indicar problemas de dimensionamento do sistema, é que os extravasores projetados simplesmente não foram executados em nenhum dos reservatórios de detenção implantados.

Relativamente à questão da existência de água no interior de alguns dos reservatórios, trata-se da vontade dos próprios moradores. De maneira geral, todos os registros de gaveta (figura 61) que controlam os volume de armazenamento ficam 
continuamente abertos, não sendo atendidas as orientações prescritas de operação dos reservatórios.
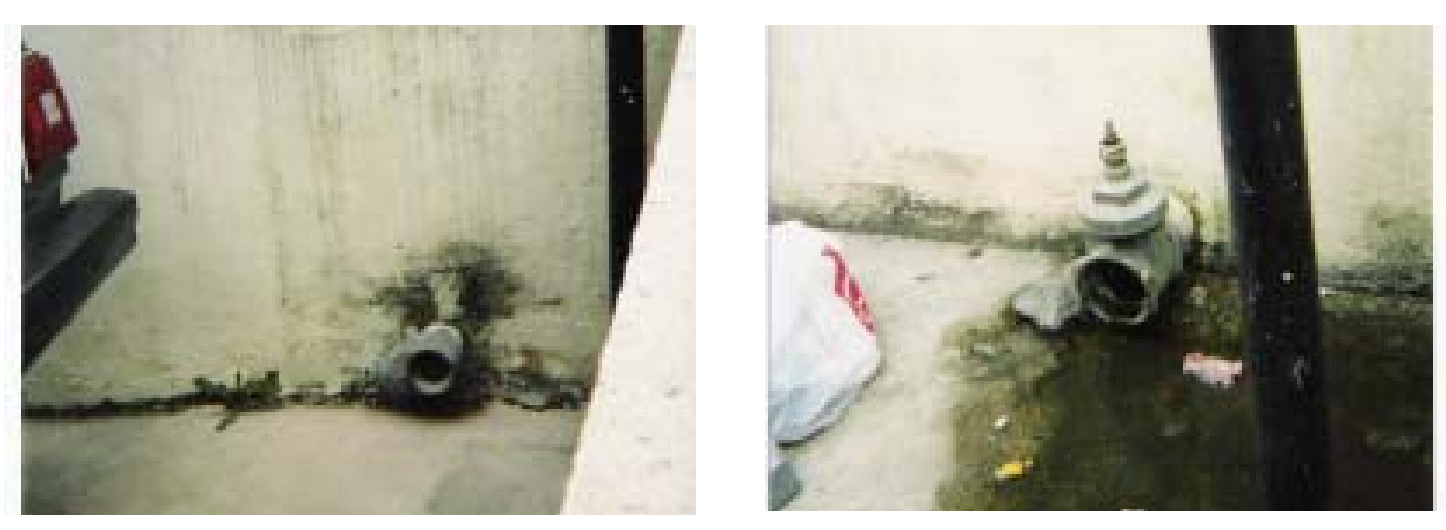

Figura 61 - Registros de gaveta abertos ou parcialmente abertos dos sistemas de descarga dos reservatórios de detenção

Alguns condomínios fazem o controle do nível das águas armazenadas porque entendem que as mesmas devem ser reaproveitadas para outros usos, como a lavagem de veículos, e assim, controlam os volumes de acordo com a necessidade, e se queixam da inexistência de um sistema que facilite a utilização da água e da formação de lodo no interior dos reservatórios.

Outro comentário feito, foi que logo após a conclusão dos reservatórios e antes da ocupação do empreendimento, um funcionário da construtora abriu todos os dispositivos de saída, liberando os volumes armazenados durante a chuva de uma só vez, o que deve acontecer conforme a legislação vigente, e o que se viu foi uma vazão maior do que aquela propiciada pela maioria das precipitações, podendo provocar estragos maiores do que normalmente ocorreria (figura 62). Esse fato demonstra que há indícios de agravamento das cheias, ao invés de atenuação, na operação dos reservatórios, mesmo em conformidade com o decreto estabelecido pelo município de São Paulo ${ }^{128}$.

\footnotetext{
${ }^{128}$ Observa-se que foi utilizado período de retorno de 10 anos para dimensionamento dos dispositivos de saída, o que corresponde a um precipitação com probabilidade de ocorrência de $10 \%$ num ano qualquer, não caracterizando as chuvas mais rotineiras. Porém, como o sistema deve armazenar todas as chuvas, indiferentemente do seu período de retorno, por uma hora, a ocorrência de períodos de retorno artificiais de 10 anos poderá ocorrer com freqüência muito maior.
} 


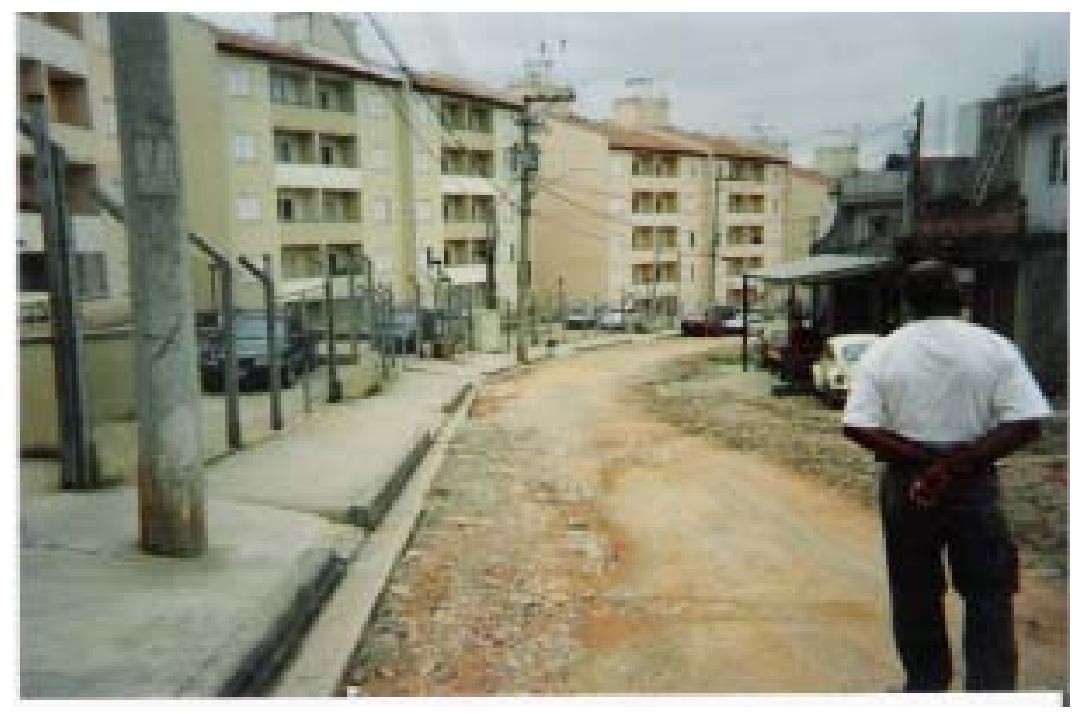

Figura 62 - Sistema viário que recebe a água armazenada nos reservatórios

Outro detalhe construtivo projetado e executado em desacordo refere-se às tampas de acesso para inspeção. Segundo o projeto, cada acesso deveria ser composto por 3 tampas de concreto com alças para facilitar a remoção e a manutenção dos reservatórios. Como pode-se observar pela figura 63, os acessos existentes são compostos por uma só tampa de concreto com alças praticamente chumbadas na estrutura, compondo dispositivo pesado e de difícil remoção.

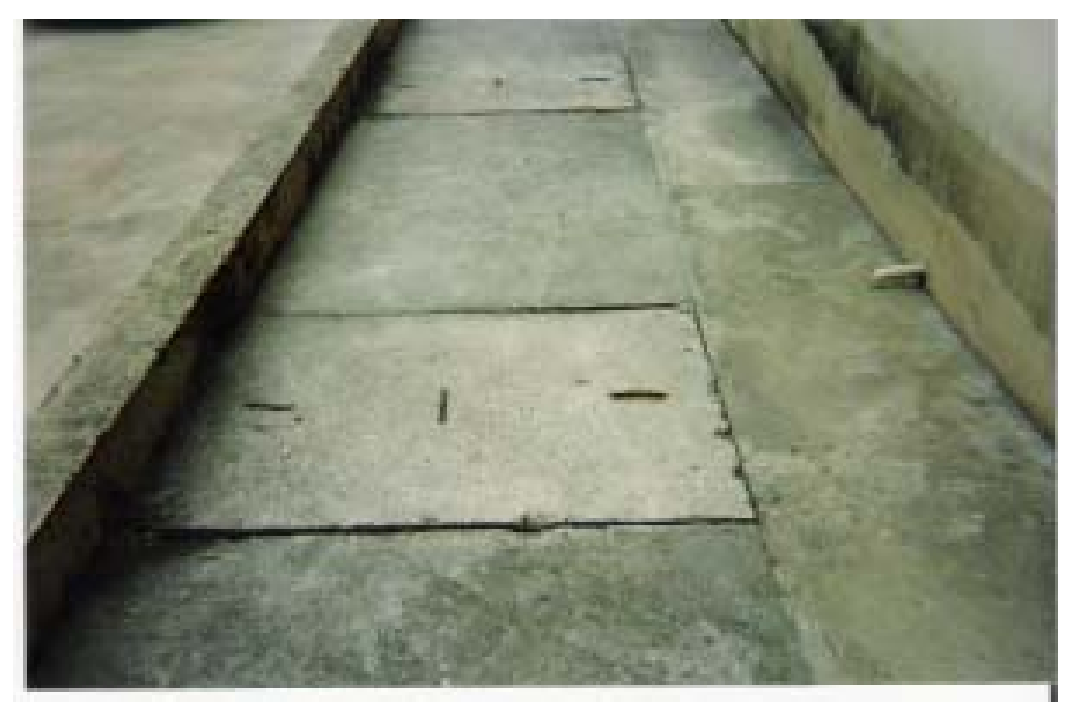

Figura 63 - Tampa de acesso para inspeção existente 
Pelas frestas das tampas dos reservatórios vazios, pôde-se verificar que existe deposição de sedimentos finos ${ }^{129}$. Este fato sinaliza que, ainda que de pequeno vulto, os reservatórios de detenção acabam ajudando a melhorar a qualidade da água dos córregos e rios.

A figura 64 denuncia que o pavimento permeável composto por blocos de concreto intertravado previsto para o estacionamento, foi substituído por um piso de concreto que veda totalmente a infiltração das águas pluviais, modificando as considerações feitas no projeto de drenagem, e que ao mesmo tempo não quebra a monotonia da paisagem.

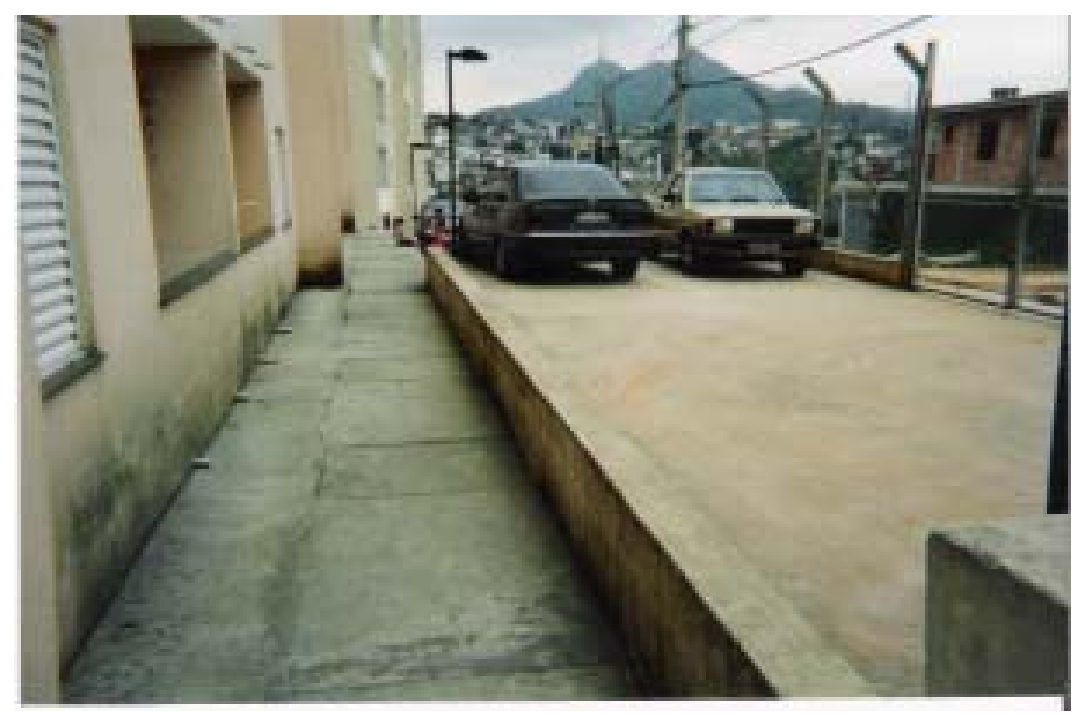

Figura 64 - Estacionamento com piso de concreto ao lado dos reservatórios de detenção

Particularmente para este conjunto onde a partir do alinhamento de fundo dos prédios não há presença de vegetação, exceto estreitas e pequenas faixas entre as canaletas de drenagem e as rampas de acesso, o uso de blocos de concreto vazado com grama poderia ao mesmo tempo, agregar valor paisagístico ao conjunto, quebrar a aridez composta pelas edificações e pisos, além de auxiliar na redução do escoamento superficial da área. A figura 65, mostra conjuntos semelhantes de vagas de estacionamento, em frente a edifícios de outros empreendimentos particulares em São Paulo, onde fica claro a amenização proporcionada pelo gramado.

\footnotetext{
129 Já esperado devido à redução da velocidade da água no interior dos mesmos, apesar da boa manutenção do sistema de drenagem do entorno.
} 

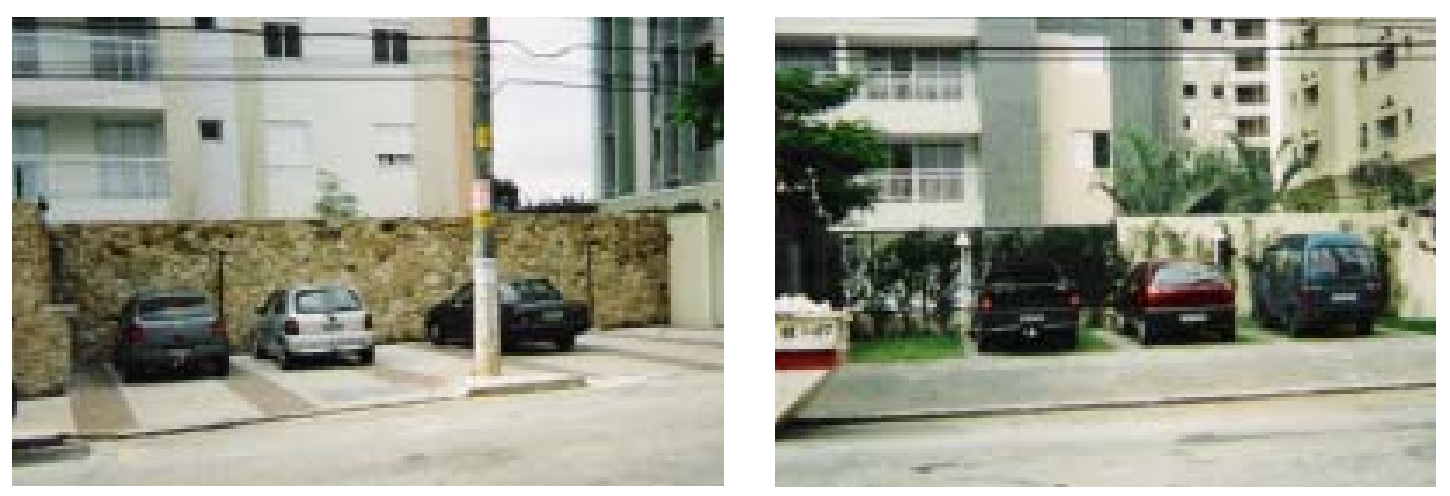

Figura 65 - Impacto visual de estacionamentos com piso permeável e impermeável

A existência dos reservatórios de detenção no Conjunto Habitacional Jaraguá $\mathrm{H}$, passa completamente despercebida para aqueles que não conhecem o projeto (figura 66), demonstrando sua total integração à composição do ambiente, não havendo com relação a este aspecto, qualquer argumentação de moradores ou urbanistas que possa desabonar sua implantação.

Apesar da constatação do último parágrafo, infelizmente a situação relatada reforça principalmente o despreparo de todos os profissionais envolvidos frente a esse "novo" dispositivo de drenagem, além de apontar possíveis problemas de concepção, dimensionamento, regras de operação e comunicação, entre outros.

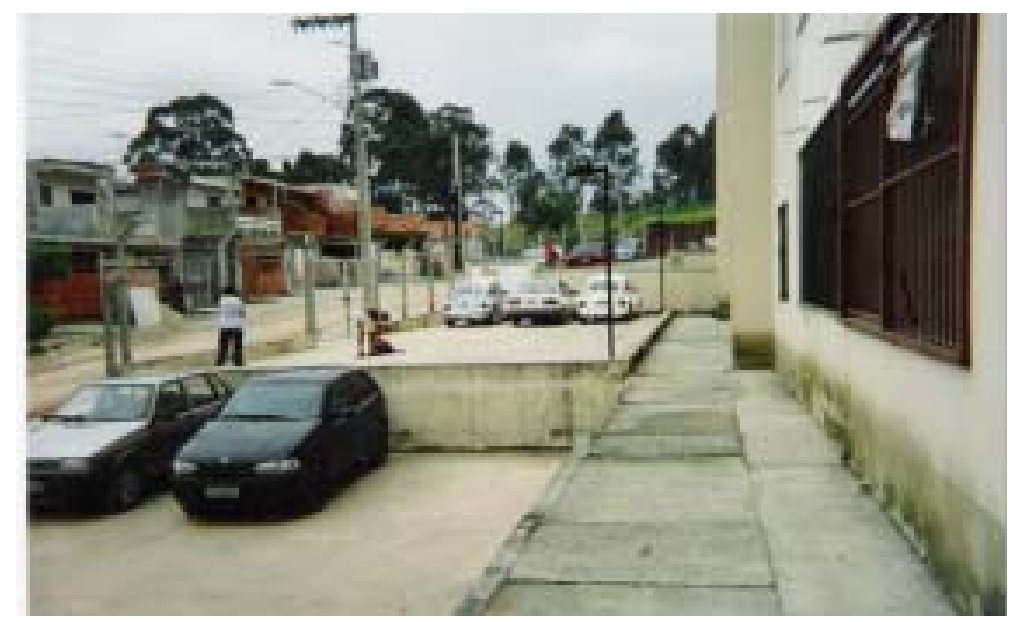

Figura 66 - Integração dos reservatórios no contexto ambiental 


\subsection{Conjunto Habitacional Vila Jacuí B1}

Este empreendimento faz parte do projeto Pantanal e ocupa uma área bastante delicada com relação às inundações que deveria estar desocupada: está localizado na região leste da cidade de São Paulo, na divisa com o município de Guarulhos, numa das margens do Rio Tietê.

A área de intervenção do projeto pantanal está confinada pelo Rio Tietê, pela ferrovia da CPTM e pela estação de tratamento de esgoto da Sabesp em São Miguel Paulista (figura 67), e foi definida como ZEIS - Zona Especial de Interesse Social pelo novo plano diretor do município de São Paulo, além de fazer parte da APA Área de Preservação Ambiental - do rio Tietê.

Desapropriada pelo DAEE - Departamento de Águas e Energia Elétrica, a área é parte do Parque Ecológico do Tietê e foi dada em permissão de uso à CDHU, com o objetivo de permitir ações de urbanização e recuperação ambiental para regularização dos assentamentos existentes.

Esta área, uma antiga várzea que sofreu sucessivos aterros ao longo dos últimos 30 anos, é composta por duas ocupações irregulares denominadas União de Vila Nova e Vila Nair e por um vazio urbano que abrigará os conjuntos habitacionais Vila Jacuí A e Vila Jacuí B1 da CDHU (figura 67).

A área comporta ainda em seu interior o córrego Jacu e o córrego Cruzeiro do Sul (figura 67), cujos projetos de canalização condicionaram as soluções de microdrenagem e urbanização.

A adoção de reservatórios de contenção de cheias para o Conjunto Habitacional Vila Jacuí B1 (figura 68), mais uma vez foi imposta pela Lei Municipal de São Paulo e resultou na criação do que se chamou "caixas de retardo", que são reservatórios de detenção com infiltração. Neste caso, diferentemente dos demais, a execução de estruturas de armazenamento foi prevista desde o projeto básico e permitiu sua evolução de simples e convencionais reservatórios de detenção para “caixas de retardo" com dupla finalidade: armazenamento e infiltração de cheias. 


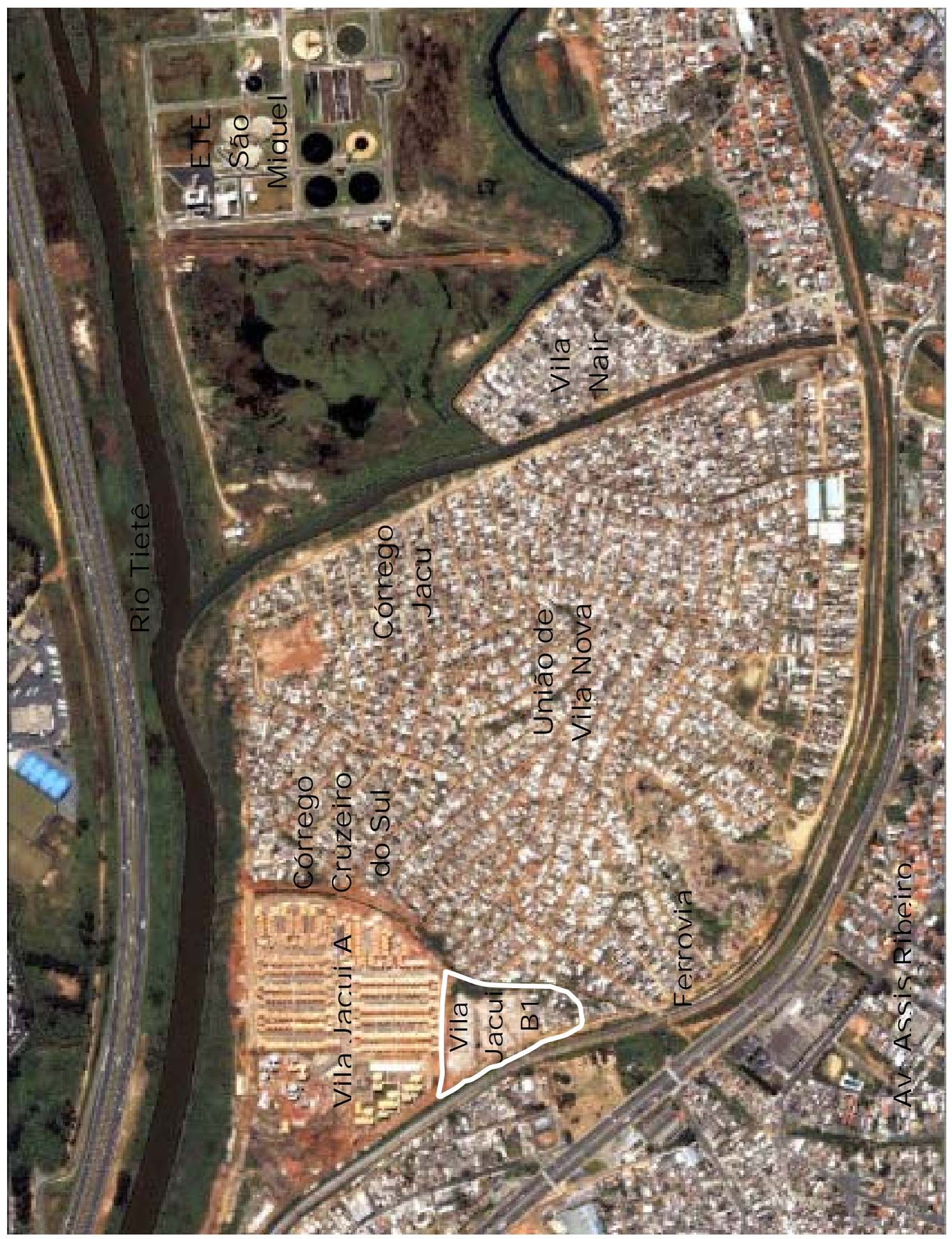

Figura 67 - Inserção do Conjunto Habitacional Vila Jacui B1

Fonte : CDHU 


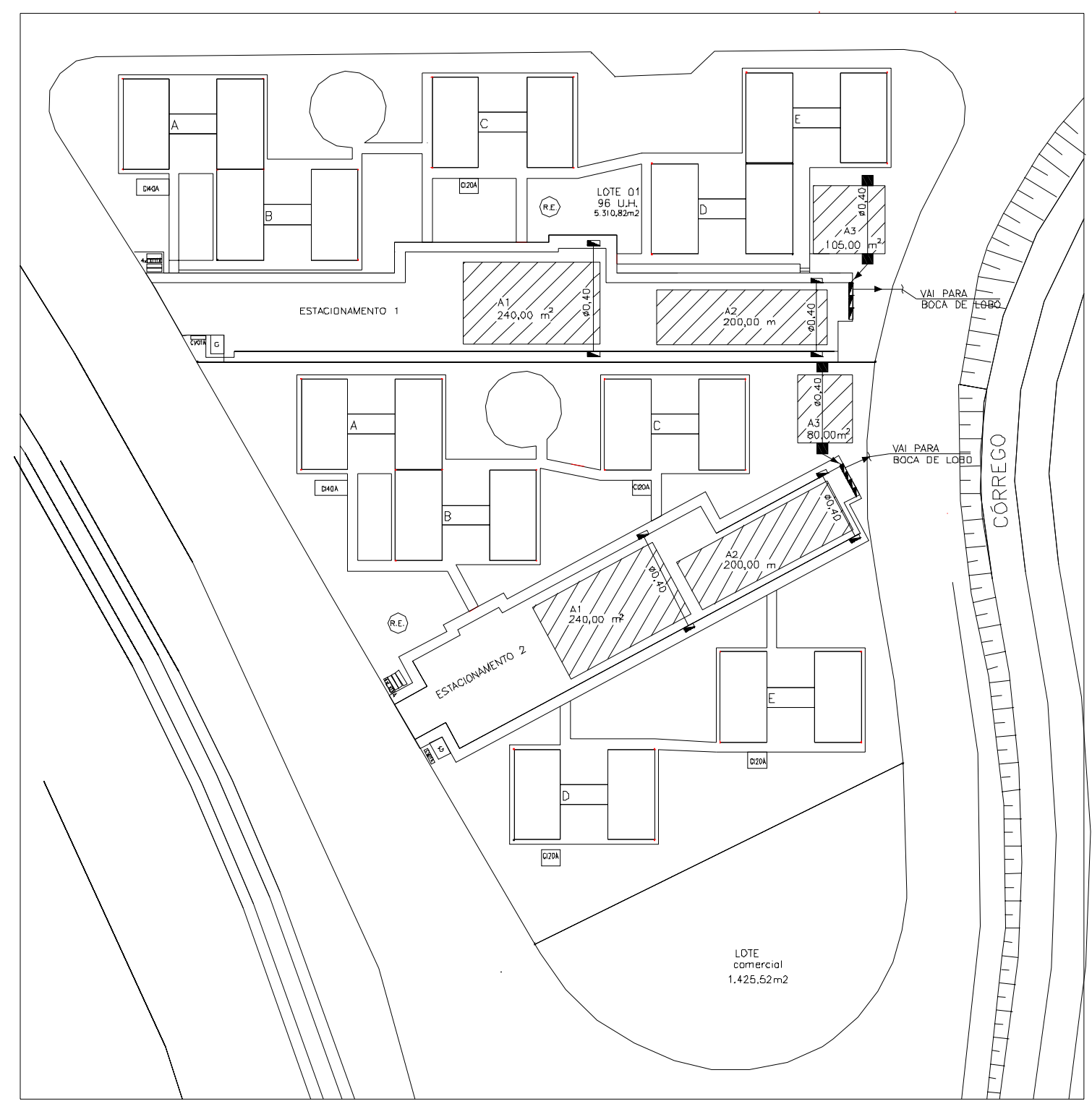

Figura 68 - Conjunto Habitacional Vila Jacuí B1 
Essa solução permitiu maximizar o aproveitamento dos espaços e evitar custos com execução de estruturas de concreto, pois foram desenvolvidas para implantação nos estacionamentos e constituem-se por colchões de pedra britada $\mathrm{n}^{\circ} 4$, envoltos por manta geotêxtil, que são alimentados por uma tubulação de PVC perfurada e conectada a bocas de lobo, que desempenham o papel de dispositivo de entrada. O posicionamento destas caixas pode ser observados na figura 68, representado pelas áreas hachuradas e o detalhamento de um desses dispositivos pode ser apreciado na figura 69.

Estes colchões drenantes possuem volume de vazios suficientes para atender às prerrogativas da legislação, satisfazendo ao mesmo tempo sua recomendação de utilizar prioritariamente processo de infiltração, desde que possível, e foram determinados pela equação estabelecida na legislação.

A extravasão do sistema ocorrerá pela inversão do processo de entrada de água, à medida que os níveis vão sendo alteados até o remanso para o estacionamento, através das bocas de lobo.

Mais uma vez, não há contribuições externas e o lixo deve ser retido nos dispositivos de drenagem adjacentes e nas estruturas de entrada.

Não há intervenção humana na operação do sistema e a manutenção deve-se restringir à retirada do lixo acumulado nos dispositivos de entrada.

Não haverá preocupações com o uso indevido da estrutura como acontece com os reservatórios convencionais e nem o perigo causado pelas águas empoçadas. Entretanto existe a preocupação com a colmatação do sistema e a necessidade futura de intervenção em áreas destinadas aos estacionamentos.

A utilização deste tipo de dispositivo de armazenamento de cheias é inédita na CDHU, e seu desempenho servirá de base para o desenvolvimento de projetos futuros. Caso a resposta seja positiva, esta nova alternativa possibilitará a minimização dos problemas de alocação de espaço, de interferências paisagísticas e de operação e manutenção, desde que respeitadas as condições de sua implantação, facilitando sua aceitação pelos envolvidos nos projetos. 


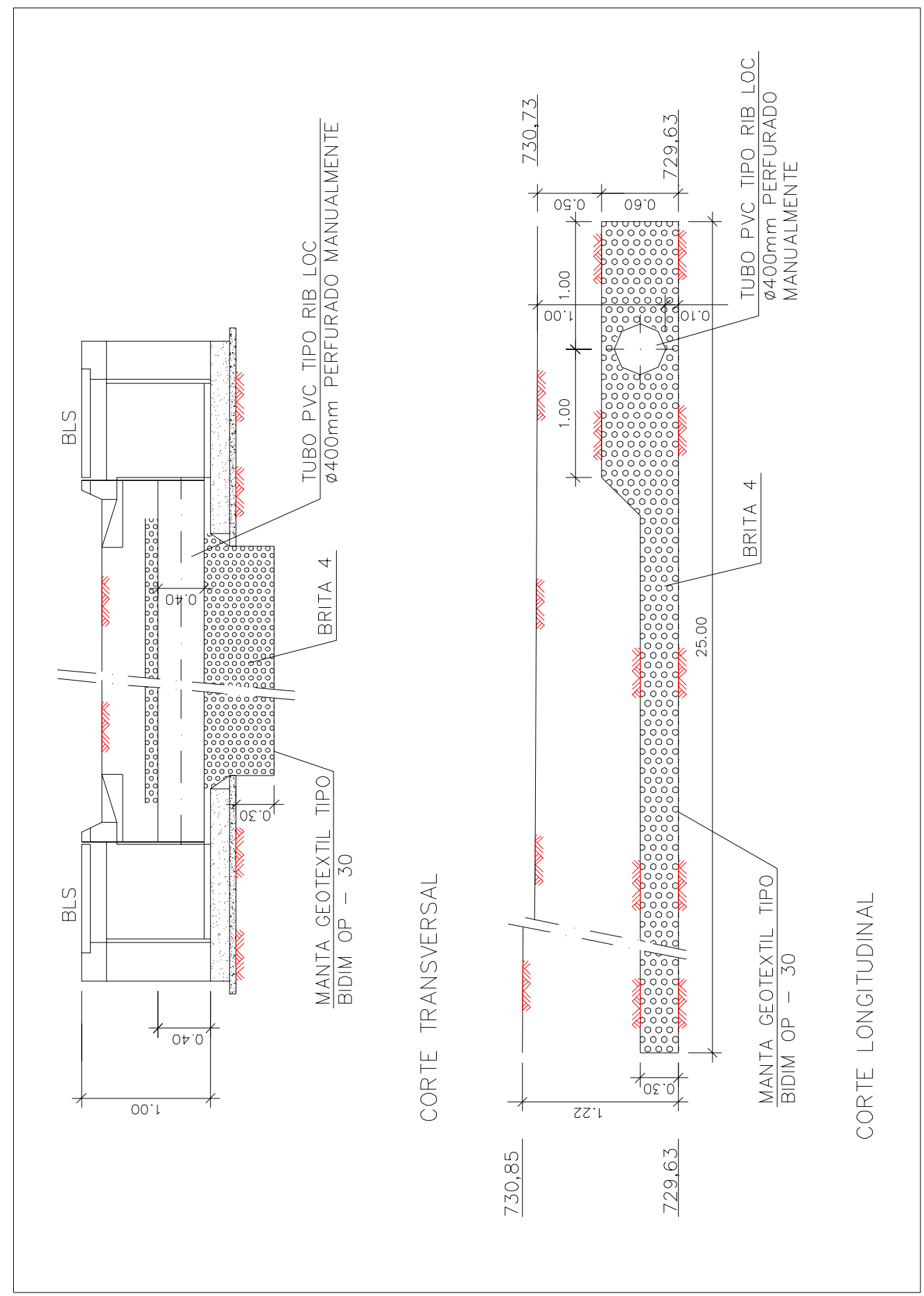

Figura 69 - Detalhes das "caixas de retardo" do Conjunto Habitacional Vila Jacuí B1 


\subsection{Conjunto Habitacional A}

O Conjunto Habitacional A (figuras 70, 71 e 72) ocupa uma área alongada, com um pequeno sistema de drenagem, através de galerias, na sua porção mais baixa.

Durante a elaboração dos projetos, mais especificamente do projeto de drenagem, que é um dos últimos a ser finalizado, o projetista informou à CDHU que havia um projeto de lei em tramitação na câmara municipal, propondo a obrigatoriedade de implantação de reservatórios de detenção em loteamentos urbanos.

A primeira reação do corpo técnico foi a de rejeitar a exigência, uma vez que haveria necessidade de revisão de todos os projetos já elaborados e pelo fato de que ainda era somente um projeto de lei. Acalmados os ânimos, consultou-se a prefeitura municipal sobre o assunto e a mesma confirmou a tendência de solicitar reservatórios de detenção para os empreendimentos realizados em sua área urbana, não podendo garantir a aprovação dos projetos após a promulgação da lei, sem seu devido atendimento. Tentou-se também acordos com a municipalidade, em função do estágio avançado dos projetos e de sua finalidade social, sem sucesso.

Assim, o empreendimento que já encontrava dificuldades para dispor de espaço para atendimento às exigências até então existentes, viu-se novamente tendo que se adequar a uma nova necessidade, no momento em que a grande maioria dos projetos já estavam praticamente concluídos.

A solução encontrada foi aproveitar parte da área livre e reduzir ao máximo o espaço destinado ao lazer para incorporar, nas áreas remanescentes, o reservatório de detenção, minimizando mudanças mais radicais.

Começava então, outra longa jornada para definição dos critérios a serem atendidos e para que o projetista conseguisse elaborar, de forma satisfatória, um reservatório de detenção, embasando tecnicamente a solução proposta e sua forma de dimensionamento. 


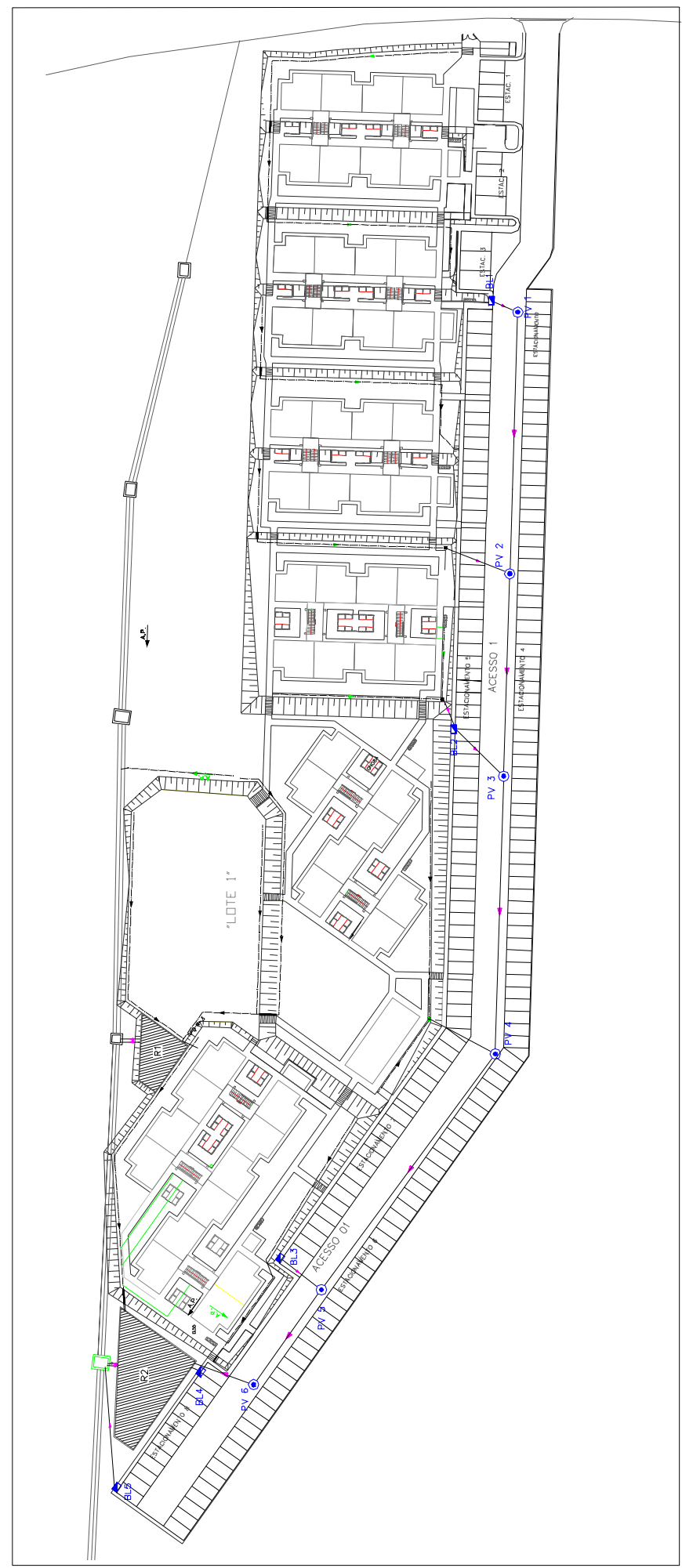

Figura 70 - Conjunto Habitacional A 


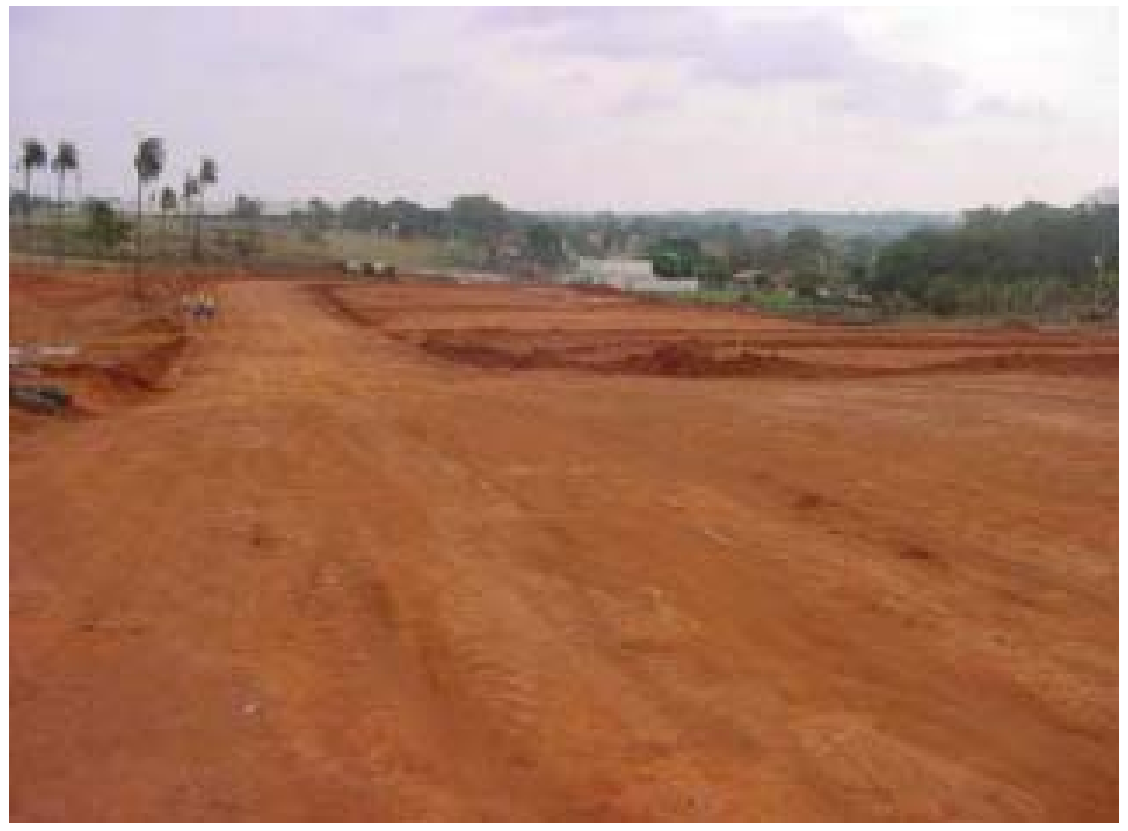

Figura 71 - Vista da área no início da urbanização Fonte: CDHU (site)

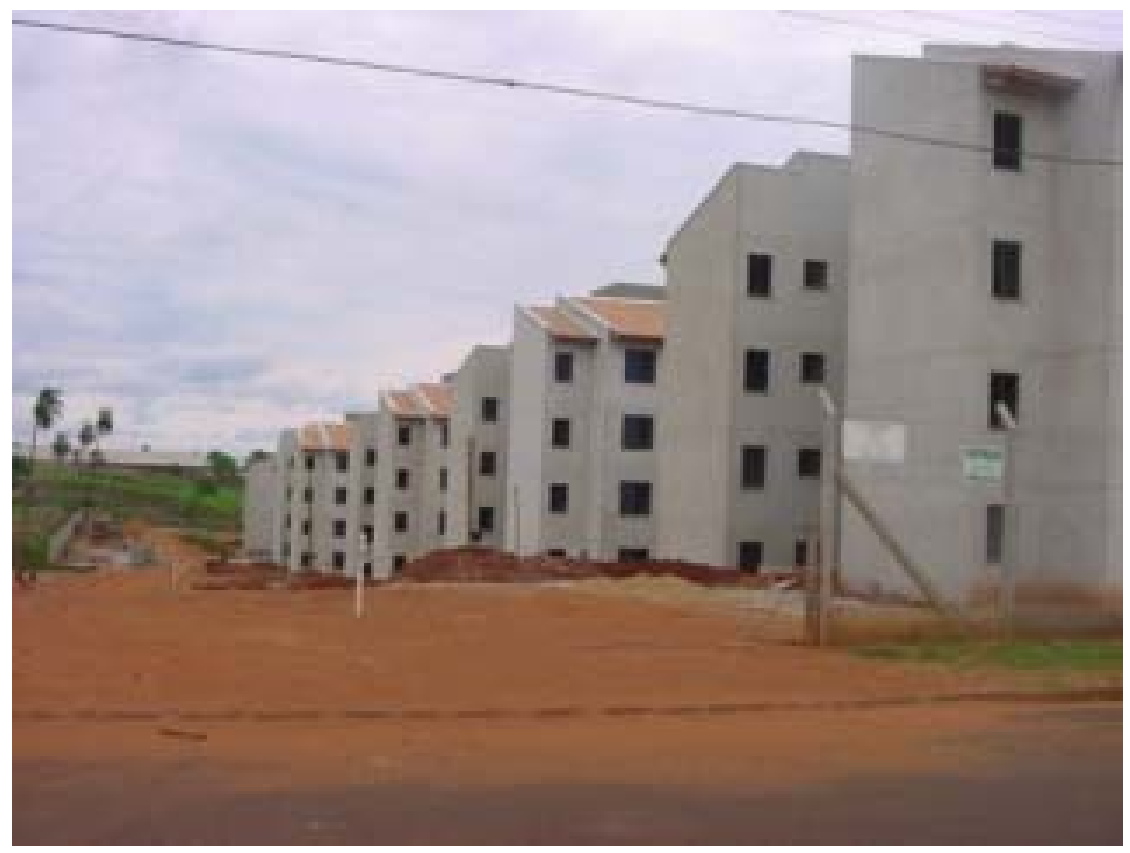

Figura 72 - Vista da área durante a execução do empreendimento Fonte: CDHU (site) 
Haviam aqui, dois grandes problemas. O primeiro, obter junto à prefeitura as diretrizes básicas e os parâmetros e critérios propostos pela lei dos reservatórios de detenção em tramitação, para que o empreendimento pudesse atender a contento as futuras exigências.

Não foram obtidos maiores esclarecimentos junto aos órgãos municipais, a não ser um valor de contribuição por metro quadrado de área do empreendimento (vazão máxima específica ?), proveniente de um estudo de macrodrenagem da bacia, ao qual não se teve acesso. Os critérios e parâmetros adotados nos projetos, ficaram então, totalmente a critério do projetista, na esperança de atendimento à futura legislação.

O segundo problema, foi a falta de familiaridade do projetista com a elaboração deste tipo de dispositivo, que mesmo extremamente simples perante as grandes estruturas implantadas no município e estado de São Paulo, fazia com que os comentários das análises do projeto e mesmo as reuniões agendadas fossem muito pouco produtivas.

Percebia-se claramente que havia uma grande confusão com relação aos conceitos empregados para o dimensionamento dos dispositivos, não sendo seguida uma só linha de raciocínio, gerando uma profusão de fórmulas e valores desconexos, difíceis de serem entendidos e depurados. Ao mesmo tempo, não havia como cobrar maior desempenho do profissional, pois no escopo do contrato para elaboração e aprovação dos projetos do empreendimento, não constava referência formal da necessidade de implantação de um reservatório de detenção e acreditava-se também, na maior capacidade técnica do mesmo e na sua versatilidade na busca de novos colaboradores.

Diante deste cenário, foram projetados na parte mais baixa do empreendimento, junto à drenagem existente, dois reservatórios de formatos irregulares, em concreto, enterrados, abertos e cercados por alambrados (figura 73), uma vez que são rodeados por edifícios e áreas de lazer condominial. 


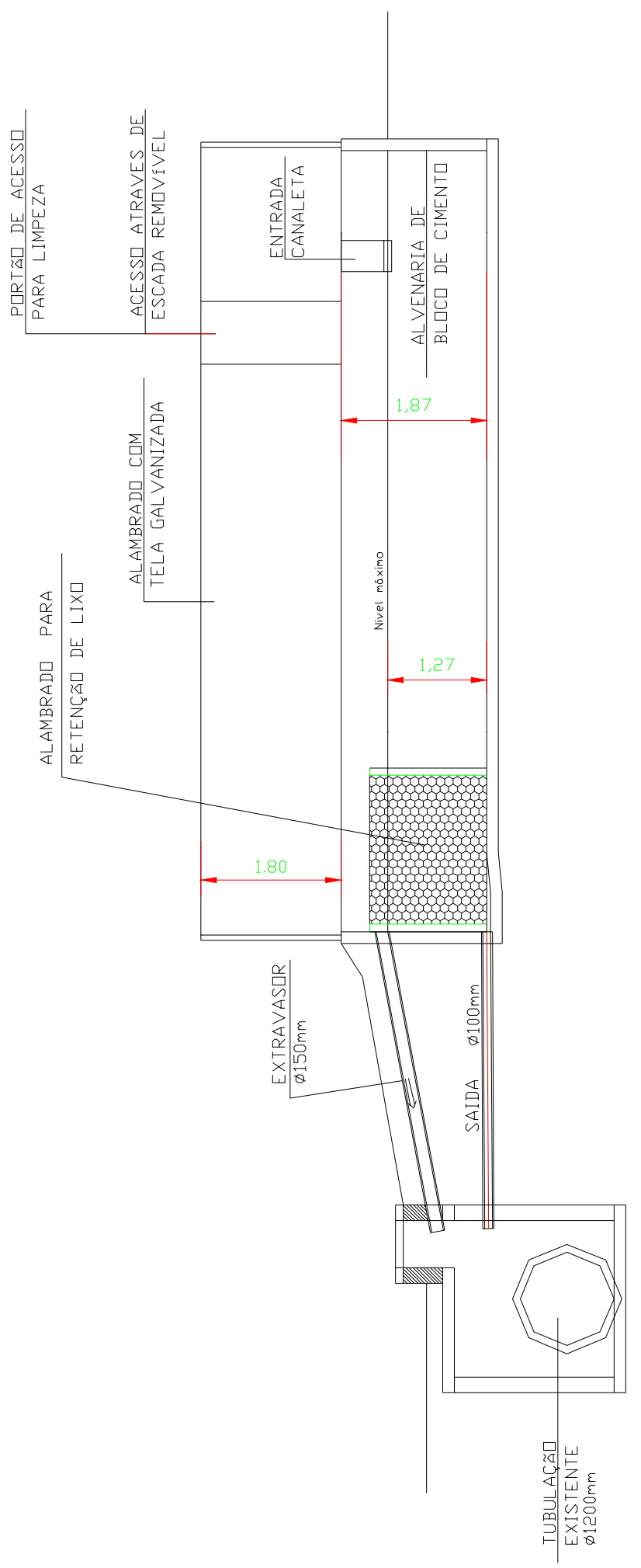

Figura 73 - Corte transversal de um dos reservatórios 
O enchimento será feito por gravidade, através dos próprios dispositivos previstos na drenagem condominial. Para permitir a manutenção e desobstrução dos dispositivos, foram previstos no alambrado de cada uma das estruturas, portões de acesso e cercamento com tela das entradas das tubulações de saída. A extravasão do sistema será feita, através de tubulações interligadas às caixas coletoras do sistema de drenagem existente.

Muitas são as preocupações que cercam a implantação destes reservatórios de detenção e seu projeto não satisfez nem os arquitetos e nem os engenheiros da CDHU, porém foram aprovados pelo órgão municipal, o que ocorreu após a promulgação da legislação específica.

\subsection{Conjunto Habitacional Herculândia C}

Dentre os casos aqui estudados, este é o único composto por unidades habitacionais horizontais (casas) (figuras 74 e 75), cujo reservatório de detenção terá aproveitamento múltiplo.

É certo que a solicitação da prefeitura foi apenas que se deixasse uma porção da área como sistema de lazer, devido ao caminhamento das águas pluviais do entorno por esta faixa em épocas de chuvas. Entretanto, estudando a bacia de contribuição (figura 76), notou-se que a área de drenagem era maior do que a esperada e que o sistema de lazer poderia ser utilizado não só para finalidades recreativas, como também para amortecimento dos picos de cheias e manutenção da vazão pré-existente (figura 77).

Como característica peculiar, a bacia de contribuição já abriga no interior de sua área, uma ferrovia e uma rodovia que atuam como bacias de amortecimento de cheias e possibilitam a inexistência de problemas de inundações à jusante, apesar da reduzida dimensão do sistema de drenagem. 


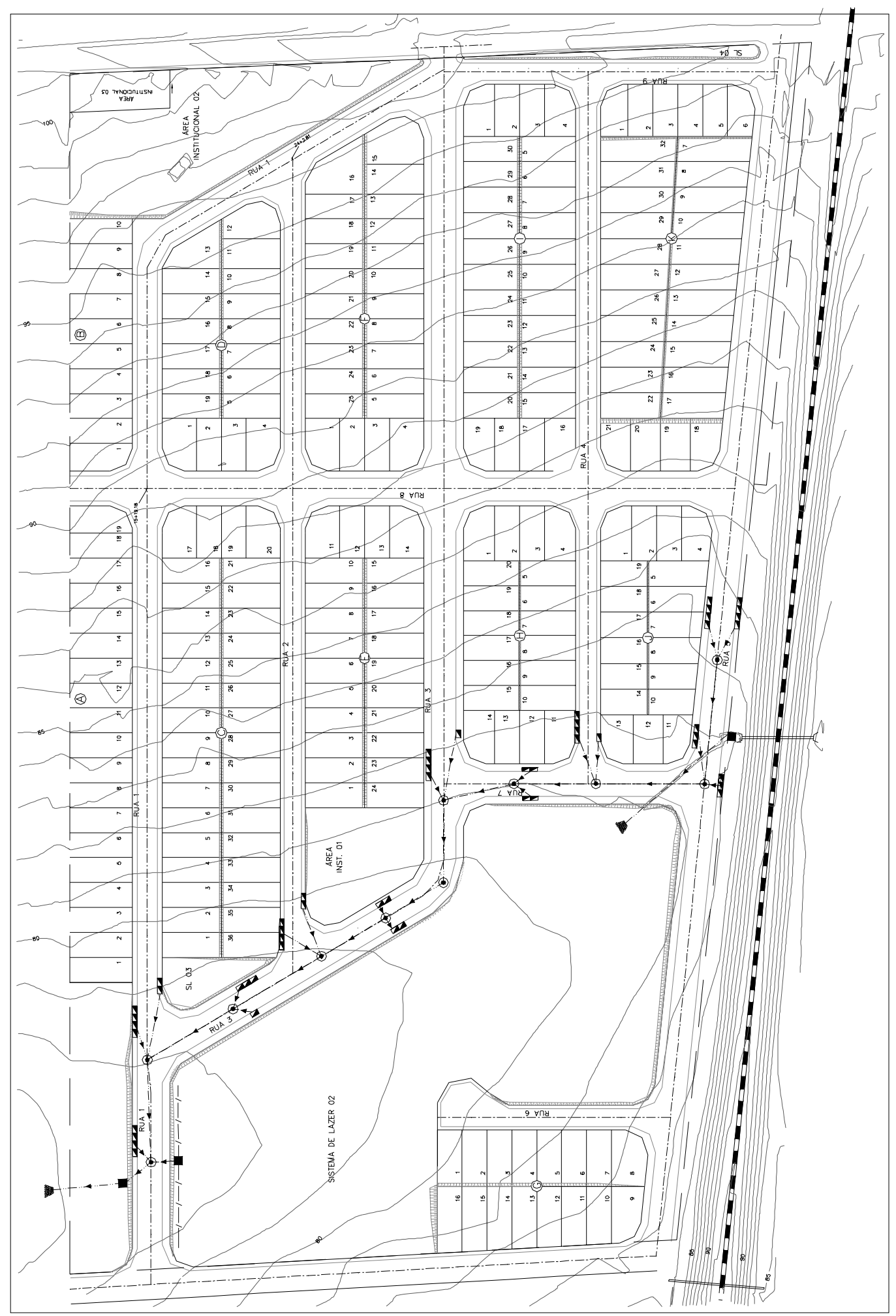

Figura 74 - Conjunto Habitacional Herculândia C 

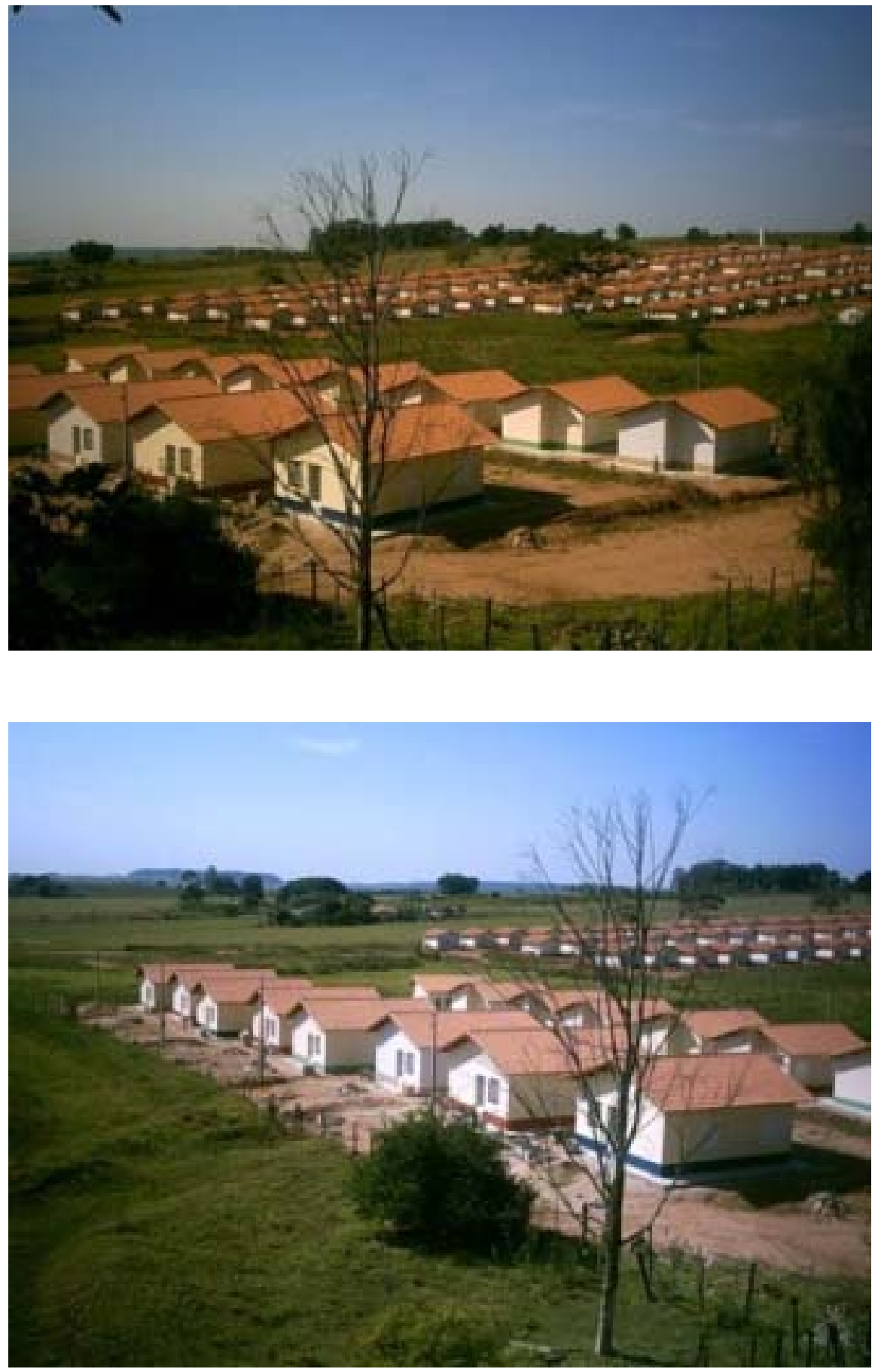

Figura 75 - Vista geral do Conjunto Habitacional Herculândia C Fonte: CDHU (site) 

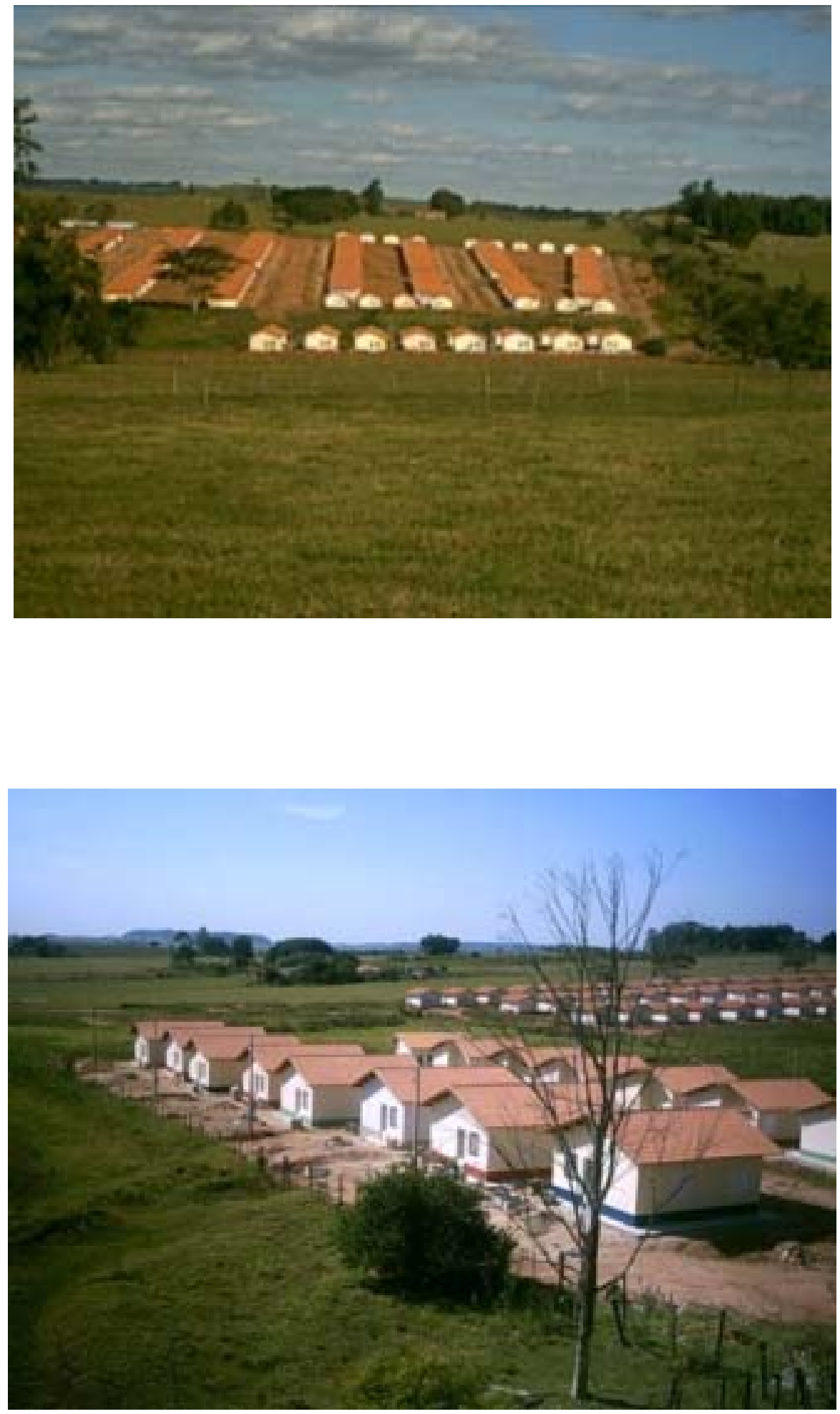

Figura 76 - Vistas parciais das bacias de contribuição Fonte: CDHU (site) 

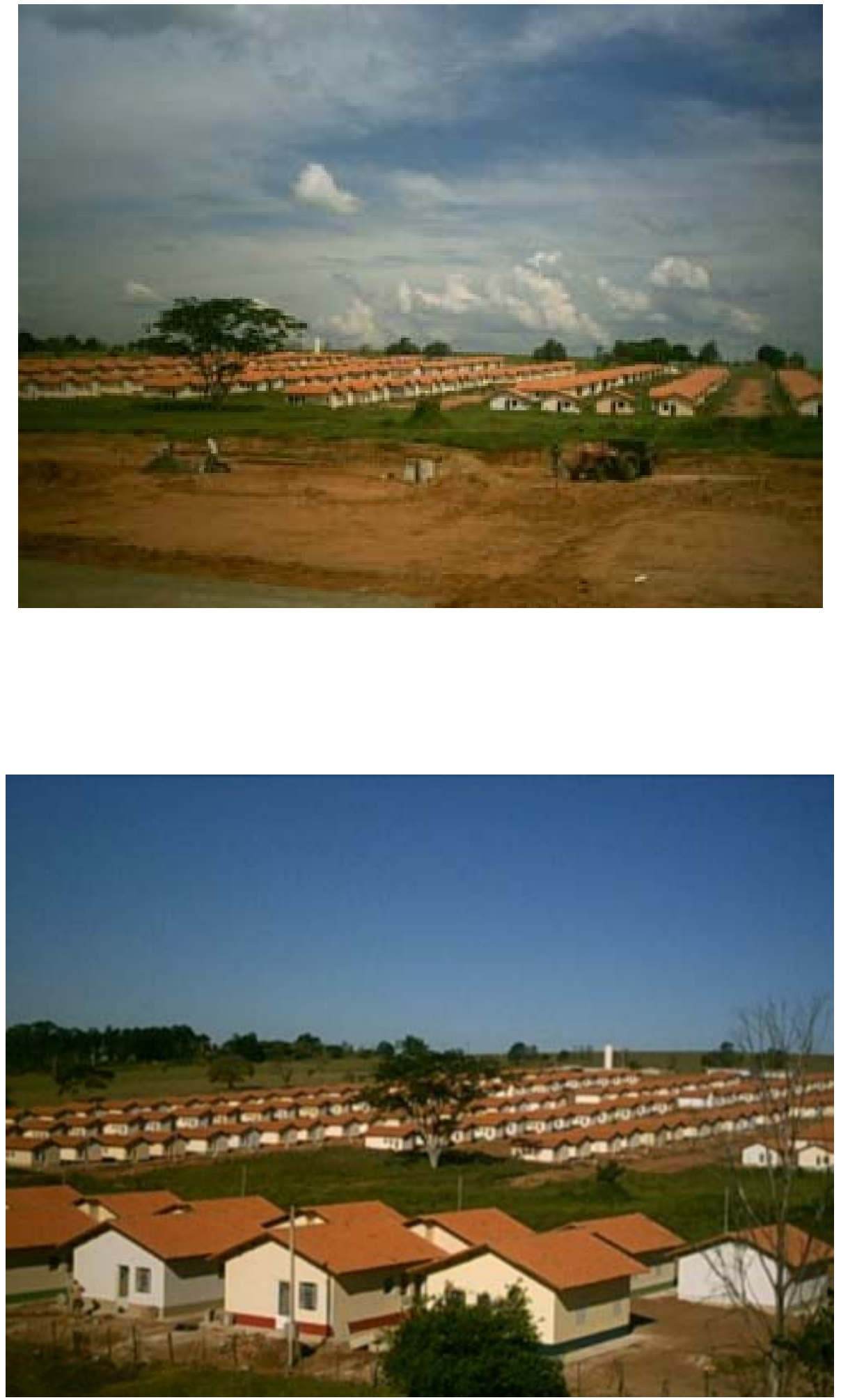

Figura 77 - Vista do sistema de lazer e do futuro reservatório Fonte: CDHU (site) 
Como o empreendimento da CDHU encontra-se no limite do perímetro urbano do município e não há outros núcleos urbanos na área da bacia, o reservatório de detenção a ser incorporado ao sistema de lazer será dimensionado apenas para armazenamento do escoamento superficial produzido no próprio empreendimento, mantendo assim a condição existente antes da urbanização da área.

A urbanização do sistema de lazer sugere a criação de um pequeno canal no talvegue existente, com dimensões suficientes para conduzir as cheias mais freqüentes, e para comportar cheias maiores, prevê-se a inundação de parte do sistema de lazer propriamente dito.

Neste caso, não está sendo prevista nenhuma estrutura de concreto para fazer o armazenamento ou impermeabilização maior do que a estritamente necessária. Ele será executado aproveitando o próprio talvegue existente, com afastamento de suas margens, criando uma área lateral aproveitada para recreação e extravasamento de vazões de maior porte.

O dispositivo de saída servirá para liberação gradual das cheias, acompanhando o nível de água no reservatório e ao mesmo tempo será utilizado como extravasor quando o nível máximo for alcançado.

O nivelamento do terreno para implantação do sistema de lazer deverá prever formas de acesso para correta manutenção do reservatório. Está sendo previsto também, sistema de proteção dos dispositivos de descarga, a fim de evitar obstruções e preservar seu funcionamento.

As maiores preocupações existentes são o aporte de resíduo sólido (lixo urbano) proveniente do próprio empreendimento, a manutenção do sistema e a correta utilização da área de recreação, devido à dupla finalidade.

Entende-se que o sistema proposto é bastante simples e que a prefeitura não terá maiores problemas com relação à manutenção, que consiste basicamente na retida do material acumulado durante as cheias no reservatório e na estrutura de saída, além de limpeza e/ou desinfecção, se necessário, das áreas impermeáveis utilizadas para lazer. Soma-se a isso o fato de que o reservatório será somente utilizado ocasionalmente, nos eventos de chuvas de maior envergadura.

Quanto à produção de resíduos sólidos, espera-se uma coleta eficiente por parte da prefeitura e a real apropriação do espaço (sistema de lazer) pela população, 
que assim ajudará a zelar pela correta disposição destes resíduos e pela conservação do local.

A execução deste reservatório de detenção não irá alterar significativamente os custos de obras deste empreendimento, pois os serviços previstos são quase os mesmos que seriam necessários para implantação do sistema de lazer. O grande acréscimo de trabalho ocorre na elaboração dos projetos, que deve considerar a existência de um elemento a mais para concepção, dimensionamento, detalhamento, compatibilização de áreas, adequação de usos, etc.,

Este empreendimento já possui todos os projetos concluídos, exceto drenagem e paisagismo que devem ser elaborados concomitantemente, para que seja possível atender o uso múltiplo definido para a área do sistema de lazer.

$\mathrm{O}$ atraso com relação aos demais projetos se deve a uma certa resistência por parte do projetista e até mesmo da própria CDHU, que apesar de considerarem a solução proposta como ambientalmente correta e adequada à situação existente, ainda relutam em aceitá-la. O primeiro porque considera que o reservatório de detenção foge do escopo dos projetos, apesar de extremamente simples, a segunda por temer a inoperância do sistema pela falta de manutenção e por questões de segurança. 


\section{SÍNTESES E AVALIAÇÕES}

Com o intuito de elucidar e comparar os casos estudados anteriormente, foram elaboradas as tabelas 30, 31, 32, 33 ,34 e 35, sintetizando os estudos de casos e as características principais de cada empreendimento. As informações contidas nessas tabelas somadas aos estudos de casos indicam/mostram que:

- quanto mais cedo for identificada a necessidade de implantação de reservatórios de detenção, melhores serão as soluções e menores serão os desgastes do corpo técnico com modificações e revisões de projetos, influindo diretamente na qualidade e custos dos empreendimentos, além de minimizar alterações nos cronogramas de obras - "a falha em incorporar a drenagem urbana na fase inicial do desenvolvimento urbano, em geral, resulta em projetos muito dispendiosos ou mesmo na sua inviabilidade técnico-econômica em estágios mais avançados" (BRAGA, 1994 apud CANHOLI,1995) e (CETESB, 1986);

- a falta de planejamento, informações, critérios e parâmetros das bacias hidrográficas, dificulta sobremaneira a implantação de estruturas de controle de cheias. É preciso que a exigência de implantação de reservatórios de detenção venha acompanhada de seus respectivos estudos, do plano diretor de drenagem urbana ou de qualquer outra fonte de esclarecimentos para os profissionais. Neste ponto é necessário que a municipalidade tenha uma atitude pró-ativa para que se possa atingir os objetivos propostos - quanto mais bem organizada estiver uma bacia hidrográfica, mais eficiente será o controle das cheias, mais fácil será a concepção e elaboração dos projetos e mais proveitoso será o resultado;

- a adoção de reservatórios de detenção se fez basicamente por imposições legais (tabela 33) - a CDHU, por seu bel prazer ou por acreditar que certas medidas são importantes, não tem a liberdade de gerar custos adicionais aos empreendimentos, principalmente por atender a uma camada da população bastante carente financeiramente. Não se tratando de uma exigência para aprovação de empreendimentos ou de solução sólida e devidamente respaldada por estudos técnicos, como por exemplo planos diretores, é difícil para a CDHU implantar novos dispositivos, além dos mínimos necessários; 
- a exigência da legislação municipal de São Paulo de armazenamento obrigatório da águas pluviais por 1 hora, praticamente obriga a adoção de sistemas elétricos para esgotamento dos reservatórios ou a criação de reservatórios com infiltração, porém esta última solução depende das características do solo, em especial da capacidade de infiltração e da qualidade da água do escoamento superficial;

- outras imposições existentes na regulamentação da legislação acima citada, como por exemplo a necessidade de serem cobertos e fechados, também restringem a criação e a implantação de reservatórios de detenção, cerceando a capacidade criativa dos profissionais, as múltiplas possibilidades de armazenamentos e a possibilidade de explorar condições naturais favoráveis;

- a exigência de implantação dos reservatórios de detenção gerou incentivos para repensar a concepção urbanística, buscar novas alternativas de projetos e materiais e forçou o intercâmbio entre profissionais de diferentes especialidades;

- a possibilidade de variação das áreas permeáveis e impermeáveis, principalmente para tipologias horizontais, é grande e imprevisível, dependendo fundamentalmente dos critérios adotados para uso e ocupação do solo, mas sobretudo da conscientização e motivação da população quanto à conservação dos índices impostos, uma vez que é difícil uma fiscalização mais efetiva - "o controle do uso e ocupação do solo só terão eficácia quando houver uma fiscalização enérgica por parte dos poderes públicos" (EMPLASA, 1995);

- a média de área impermeável nos conjuntos da CDHU gira em torno de 40 à $70 \%$ da área do empreendimento, indiferente da tipologia adotada (tabela 31). As tipologias horizontais são mais flexíveis e permitem ampliações, cujo projeto é fornecido pela própria CDHU, possibilitando consideráveis modificações quanto a áreas permeáveis e impermeáveis na área dos lotes.

- No caso do Conjunto Habitacional Herculândia C, se todas as residências fossem ampliadas e os recuos de frente (área destinada a garagens) impermeabilizados, alternativa esta bastante corriqueira, a área impermeável passaria de 41,4\% a $58,8 \%$ e a área permeável de $58,6 \%$ a $41,2 \%$. Caso a área total dos lotes fosse impermeabilizada tem-se área impermeável de 79,8\% e área permeável de $20,2 \%$, o que corresponde a quase $100 \%$ de variação, para mais ou para menos, se comparada à situação original; 
- as áreas para tráfego de veículos correspondem a parcela considerável da área impermeabilizada (entre 20 e 30\%, conforme tabela 31) e se receberem tratamento adequado podem ajudar a reduzir o escoamento superficial "pesquisadores da UFRGS (Universidade Federal do Rio Grande do Sul) demonstraram que pisos e calçadas feitos com paralelepípedos e blocos reduzem o escoamento de água de $40 \%$ a $65 \%$, enquanto um gramado detém pelo menos 95\%. Em pisos de concreto ou asfalto a possibilidade de infiltração é de apenas $5 \%{ }^{130}$ (FIORAVANTI, 2004);

- operação e manutenção dos sistemas (tabela 34), exceto no Conjunto Habitacional Herculândia C, estão sob responsabilidade dos moradores e são com certeza itens críticos na implantação de reservatórios de detenção. A falha nestas duas atividades fatalmente leva à inoperância do sistema, quando não a situações de risco - "o bom funcionamento do sistema de drenagem depende de manutenção permanente" (CETESB, 1986);

- o aproveitamento dos reservatórios ainda está restrito ao armazenamento das cheias e ao controle quantitativo das vazões (tabela 34), apesar destes serem dependentes da qualidade do escoamento superficial e de certa forma ajudarem a melhorá-la;

- Os reservatórios de detenção não estão sendo executados conforme projetados (tabela 35). Existem problemas de comunicação entre projetos e obras ou insatisfação de obras com as soluções desenvolvidas nos projetos - "o bom funcionamento do sistema de drenagem depende essencialmente da execução cuidadosa das obras conforme projetadas" (CETESB, 1986);

- A tabela 35 demonstra a situação crítica dos reservatórios vistoriados e indica a necessidade de revisão e aperfeiçoamento dos conceitos e critérios de implantação dos mesmos. Além disso, denota a necessidade de procurar soluções alternativas mais sustentáveis frente ao público atendido e que não demandem operação, ao mesmo tempo em que reduzam a periodicidade e também os custos de manutenção;

- O saldo das experiências práticas com reservatórios de detenção em conjuntos habitacionais da CDHU revelaram-se negativas, em maior ou menor grau,

\footnotetext{
${ }^{130}$ Observar considerações feitas no capítulo 3, item 3.2.2.
} 
demonstrando a necessidade de aprofundamento no assunto, principalmente frente à crescente exigência legal;

- É preciso que haja por parte da CDHU, um acompanhamento contínuo dos reservatórios implantados e a implantar, para que estes forneçam subsídios aos futuros projetos, frente à particularidade de seus empreendimentos e público alvo;

- Os profissionais do mercado não estão preparados para a tarefa de implantar reservatórios de detenção e há grande insegurança no desenvolvimento desta atividade. A simples aplicação das fórmulas existentes nas legislações específicas não é suficiente para equacionar questões de armazenamento;

- Os custos de implantação mostraram-se pouco significativos em relação ao custo total dos empreendimentos, girando em torno de no máximo 2,5\%. Porém, o custo por $\mathrm{m}^{2}$ varia consideravelmente em função do tipo de estrutura (tabela 34);

- Por tratar-se de dispositivo novo para a grande maioria dos profissionais e população em geral, ainda é necessário esclarecer sua finalidade e sua forma de atuação na drenagem urbana. A implantação de reservatórios de detenção ainda é vista com ressalvas e certa desconfiança;

- É necessário colaboração maior da prefeitura na tarefa de sensibilização da população e orientação dos profissionais, sempre que a exigência partir de legislações municipais. Isso não exclui a necessidade de melhor esclarecer a sociedade sobre práticas alternativas de controle de inundações tanto por parte dos governantes quanto por parte da mídia.

$\mathrm{Na}$ tabela 36, 37, 38, 39 e 40 são apresentadas as principais questões levantadas, suas causas e possíveis soluções. Nos itens posteriores deste trabalho serão discriminados de forma mais ampla os assuntos considerados fundamentais para encaminhamento das questões levantadas, agrupados em 4 temas: planejamento, considerações técnicas, impactos econômicos e impactos sociais. 
Tabela 30- Síntese da apresentação dos estudos de $\operatorname{casos}^{131}$

\begin{tabular}{|c|c|c|}
\hline Peculiaridade do sistema & Problemas de implantação & Preocupações futuras \\
\hline \multicolumn{3}{|c|}{ Itaquera $\mathrm{C}$} \\
\hline $\begin{array}{|ll|}- & \text { pioneiro na CDHU; } \\
- & \text { antecedeu a promulgação } \\
& \text { da legislação específica; } \\
\text { - } & \text { implantado após a } \\
& \text { entrega do conjunto; } \\
\text { - } & \text { solicitado por } \\
& \text { representante da } \\
& \text { comunidade local. } \\
\end{array}$ & $\begin{array}{ll}- & \text { falta de previsão inicial; } \\
- & \text { falta de espaço; } \\
- & \text { interferências na vida } \\
& \text { condominial. }\end{array}$ & $\begin{array}{ll}\text { - } & \text { aceitação pelos } \\
& \text { moradores; } \\
\text { - } & \text { manutenção correta; } \\
\text { - } & \text { eficiência do sistema; } \\
\text { - } & \text { alcance dos objetivos } \\
& \text { propostos; } \\
\text { - } & \text { integração ao meio } \\
& \text { ambiente. } \\
\end{array}$ \\
\hline \multicolumn{3}{|c|}{ Jaraguá H } \\
\hline $\begin{array}{|ll|}- & \text { tem operação manual; } \\
\text { - } & \text { primeiro implantado com } \\
& \text { base em legislação } \\
& \text { específica. }\end{array}$ & 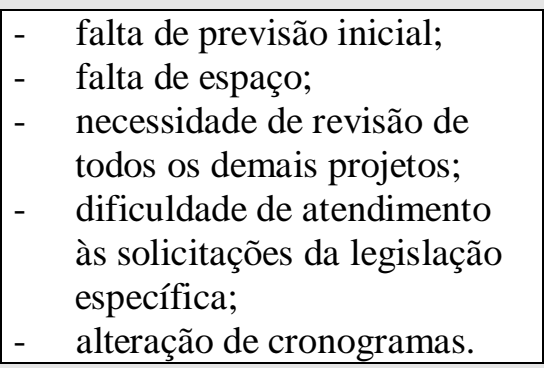 & $\begin{array}{ll}\text { - } & \text { Operação correta; } \\
\text { - } & \text { Eficiência do sistema. }\end{array}$ \\
\hline \multicolumn{3}{|c|}{ Vila Jacuí B1 } \\
\hline \begin{tabular}{|ll} 
- & solução inovadora com \\
& dupla finalidade; \\
- & não subtrai área útil do \\
& empreendimento; \\
- & previsto desde a fase \\
& inicial. \\
\end{tabular} & $\begin{array}{ll}- & \text { possibilidade de colmatação } \\
\text { do sistema }\end{array}$ & $\begin{array}{ll}\text { - } & \text { eficiência do sistema; } \\
\text { - } & \text { necessidade de } \\
& \text { intervenção precoce. }\end{array}$ \\
\hline \multicolumn{3}{|c|}{ Conjunto A } \\
\hline 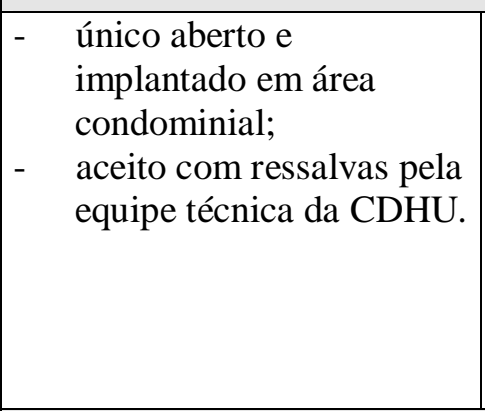 & $\begin{array}{ll}\text { - } & \text { falta de previsão inicial; } \\
\text { - } & \text { falta de espaço; } \\
\text { - } & \text { necessidade de revisão dos } \\
& \text { demais projetos; } \\
\text { - } & \text { alteração de cronogramas; } \\
\text { - } & \text { falta de parâmetros e } \\
& \text { critérios; } \\
\text { - } & \text { formação inadequada e falta } \\
& \text { de atualização profissional }\end{array}$ & $\begin{array}{ll}\text { - } & \text { eficiência do sistema; } \\
\text { - } & \text { integração ao meio } \\
& \text { ambiente; } \\
\text { - } & \text { aceitação pelos } \\
& \text { moradores. }\end{array}$ \\
\hline \multicolumn{3}{|c|}{ Herculândia $\mathrm{C}$} \\
\hline $\begin{array}{|ll|}\text { - } & \text { único com uso múltiplos; } \\
\text { - } & \text { será implantado em área } \\
& \text { pública; } \\
\text { - } & \text { não há legislação } \\
& \text { específica. } \\
\end{array}$ & $\begin{array}{|ll|}- & \text { falta de previsão inicial; } \\
\text { - } & \text { resistência na adoção da } \\
& \text { solução por parte da CDHU e } \\
& \text { do projetista. }\end{array}$ & $\begin{array}{ll}\text { - } & \text { eficiência do sistema; } \\
\text { - } & \text { apropriação e uso } \\
& \text { correto; } \\
\text { - } & \text { correta manutenção; } \\
\text { - } & \text { aporte de sedimentos. }\end{array}$ \\
\hline
\end{tabular}

${ }^{131}$ A situação atual dos reservatórios que já estão implantados encontra-se apresentada na tabela 35. 
Tabela 31 - Características urbanísticas dos empreendimentos

\begin{tabular}{|c|c|c|c|c|c|}
\hline Empreendimento & Itaquera C3 & Jaraguá H & Vila Jacuí B1 & Conjunto A & Herculândia C \\
\hline Programa CDHU & $\begin{array}{c}\text { mutirão } \\
\text { associativo }\end{array}$ & $\begin{array}{l}\text { empreitada } \\
\text { global }\end{array}$ & $\begin{array}{c}\text { atuação em } \\
\text { favelas e áreas } \\
\text { de risco }\end{array}$ & $\begin{array}{l}\text { empreitada } \\
\text { global }\end{array}$ & $\begin{array}{l}\text { empreitada } \\
\text { global }\end{array}$ \\
\hline Município & São Paulo & São Paulo & São Paulo & interior de SP & Herculândia \\
\hline Inserção urbana & $\begin{array}{c}\text { área } \\
\text { densamente } \\
\text { urbanizada }\end{array}$ & área urbanizada & $\begin{array}{c}\text { área } \\
\text { densamente } \\
\text { urbanizada }\end{array}$ & área urbanizada & $\begin{array}{l}\text { limite de } \\
\text { perímetro } \\
\text { urbano }\end{array}$ \\
\hline Tipologia & vertical & vertical & vertical & vertical & horizontal \\
\hline Área total do empreendimento $\left(\mathrm{m}^{2}\right)$ & $9.549,00$ & $9.728,00$ & $11.091,00$ & $15.365,00$ & $129.385,00$ \\
\hline Área das edificações $\left(\mathrm{m}^{2}\right)$ & $3.450,00$ & $4.565,00$ & $2.211,00$ & $2.935,00$ & $18.064,00$ \\
\hline Área permeável $\left(\mathbf{m}^{2}\right)$ & $3.649,00$ & $3.057,00$ & $6.283,00$ & $8.365,00$ & $75.788,00$ \\
\hline Porcentagem área das edificações (\%) & 36,1 & 46,9 & 19,9 & 19,1 & 14,0 \\
\hline Porcentagem área de tráfego veículos (\%) & 25,7 & 21,7 & 23,4 & 26,5 & 27,4 \\
\hline Porcentagem demais áreas (\%) & 38,2 & 31,4 & 56,7 & 54,4 & 58,6 \\
\hline Porcentagem área impermeável (\%) & 61,8 & 68,6 & 43,4 & 45,6 & 41,4 \\
\hline Porcentagem área permeável (\%) & 38,2 & 31,4 & 56,6 & 54,4 & 58,6 \\
\hline
\end{tabular}

* inclui área necessária para acomodação de taludes. 
Tabela 32 - Características físicas dos reservatórios de detenção

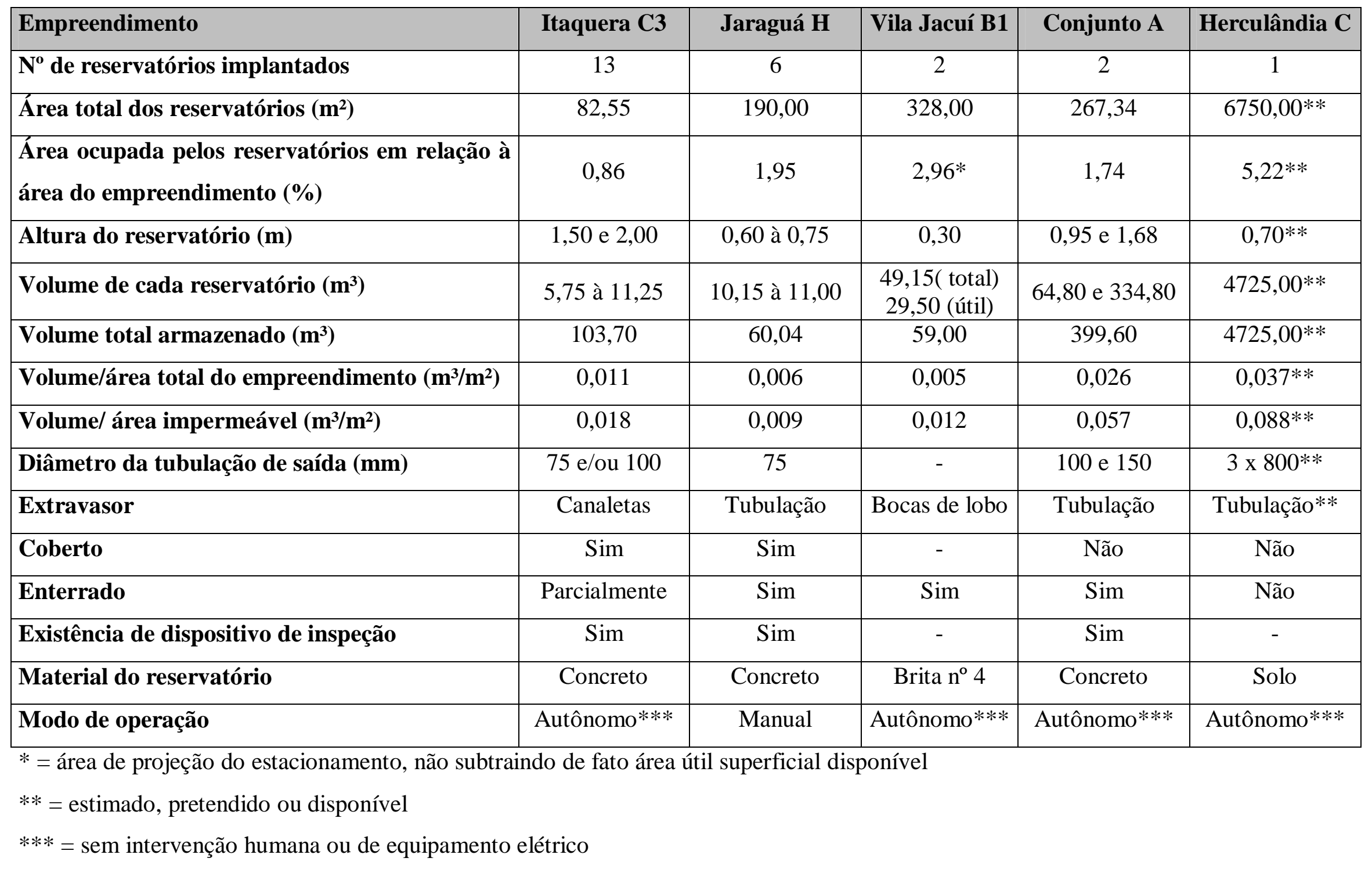


Tabela 33 - Parâmetro e critérios de dimensionamento

\begin{tabular}{|c|c|c|c|c|c|}
\hline Empreendimento & Itaquera C3 & Jaraguá $\mathbf{H}$ & Vila Jacuí B1 & Conjunto A & Herculândia C \\
\hline Critério de dimensionamento & $\begin{array}{l}\text { Vazão pré- } \\
\text { existente }\end{array}$ & $\begin{array}{c}\text { Legislação } \\
\text { (PMSP) }\end{array}$ & $\begin{array}{c}\text { Legislação } \\
\text { (PMSP) }\end{array}$ & $\begin{array}{l}\text { Vazão máx. } \\
\text { específica saída }\end{array}$ & $\begin{array}{c}\text { Vazão pré- } \\
\text { existente / } \\
\text { capacidade máx. }\end{array}$ \\
\hline $\begin{array}{l}\text { Método de cálculo do volume de } \\
\text { armazenamento }\end{array}$ & $\begin{array}{c}\text { Simplificado } \\
\text { (McCuen) }\end{array}$ & $\begin{array}{c}\text { Legislação } \\
\text { (PMSP) }\end{array}$ & $\begin{array}{c}\text { Legislação } \\
\text { (PMSP) }\end{array}$ & $\begin{array}{l}\text { Simplificado } \\
\text { (Muller- } \\
\text { Neuhaus) }\end{array}$ & $\begin{array}{l}\text { Amortecimento } \\
\qquad \text { (Pulz ou } \\
\text { similar**) }\end{array}$ \\
\hline Período de retorno & 10 & $10^{*}$ & $10 *$ & 10 & $25 * *$ \\
\hline Coeficiente de escoamento pré-urbanização & 0,4 & - & - & 0,20 & $0,40 * *$ \\
\hline Coeficiente de escoamento pos-urbanização & 0,9 & - & - & 0,65 & $0,50 * *$ \\
\hline Equação de chuvas & SP (PSW) & SP (PSW) & SP (PSW) & Local & Local \\
\hline Tempo concentração pré-urbanização (min) & 10 & - & - & 60 & $30 * *$ \\
\hline Tempo concentração pos-urbanização (min) & $10 * * *$ & $60 *$ & $60 *$ & 60 & $30 * *$ \\
\hline Método de cálculo do dispositivo de saída & orifício & orifício & infiltração & orifício & Orifício** \\
\hline Coeficiente de descarga & 0,63 & 0,61 & - & 0,64 e 0,75 & $0,63 * *$ \\
\hline Método de cálculo do extravasor & conduto livre & conduto livre & - & conduto livre & $\begin{array}{l}\text { conduto livre / } \\
\text { bueiro de } \\
\text { travessia** }\end{array}$ \\
\hline
\end{tabular}

* = implícito na equação do cálculo de volume da legislação específica

$* *=$ Estimado ou pretendido

*** = variação muito pequena em função das dimensões da bacia 
Tabela 34 - Custos e outras informações

\begin{tabular}{|c|c|c|c|c|c|}
\hline Empreendimento & Itaquera C3 & Jaraguá $\mathbf{H}$ & Vila Jacuí B1 & Conjunto A & Herculândia C \\
\hline Solicitação do reservatório & sociedade & legislação & legislação & "legislação" & "prefeitura" \\
\hline Área da bacia de drenagem $\left(\mathrm{m}^{2}\right)$ & $8.234,00$ (lote) & $9.728,00$ (lote) & $11.091,00$ (lote) & $15.365,00$ (lote) & $1.329 .385,00$ \\
\hline $\begin{array}{l}\text { Fase do empreendimento quando houve a } \\
\text { solicitação do reservatório }\end{array}$ & após ocupação & $\begin{array}{l}\text { elaboração do } \\
\text { projeto }\end{array}$ & $\begin{array}{l}\text { concepção do } \\
\text { projeto }\end{array}$ & $\begin{array}{l}\text { elaboração do } \\
\text { projeto }\end{array}$ & $\begin{array}{l}\text { elaboração do } \\
\text { projeto }\end{array}$ \\
\hline Outros aproveitamentos & não & não & não & não & $\operatorname{sim}$ \\
\hline Responsável pela manutenção & moradores & moradores & moradores & moradores & prefeitura \\
\hline Revisão e intervenção em projetos existentes & $\operatorname{sim}$ & $\operatorname{sim}$ & não & $\operatorname{sim}$ & não \\
\hline Custo dos reservatórios $(\mathbf{R} \$)$ & $\begin{array}{c}76.956,01 \\
(\text { out } / 01)\end{array}$ & $\begin{array}{c}74.978,04 \\
(\mathrm{jan} / 01)\end{array}$ & $\begin{array}{l}54.495,00 \\
\text { (maio/04) }\end{array}$ & $\begin{array}{l}120.000,00^{*} \\
\text { (maio/04) }\end{array}$ & $\begin{array}{c}73.000,00^{*} \\
(\mathrm{dez} / 04)\end{array}$ \\
\hline $\begin{array}{l}\text { Custo dos reservatórios em relação ao custo } \\
\text { do empreendimento }(\%)\end{array}$ & 1,93 & 1,22 & 0,80 & $2,47 *$ & $1,32 *$ \\
\hline Volume necessário leg. específica PMSP & 53,1 & 60,0 & 43,3 & 63,0 & 482,0 \\
\hline Volume alocado / volume leg. espec. PMSP & 2,5 & 1,0 & 1,4 & 6,3 & 9,8 \\
\hline
\end{tabular}

* = estimado 
Tabela 35- Situação dos reservatórios de detenção implantados

\begin{tabular}{|c|c|c|}
\hline Empreendimento & C.H. Itaquera C3 & C.H. Jaraguá H \\
\hline Data da entrega do conjunto habitacional & Dez/2000 & Dez/2003 \\
\hline $\begin{array}{l}\text { Data da implantação do reservatório de } \\
\text { detenção }\end{array}$ & 2002 & 2003 \\
\hline Data da vistoria & Fev/2005 & Fev/2005 \\
\hline $\begin{array}{l}\text { Alcance dos objetivos que justificaram a } \\
\text { implantação }\end{array}$ & Não & Muito pouco \\
\hline Estado atual do reservatório & Inoperante & Inoperante \\
\hline Problema principal & Manutenção & Execução \\
\hline Condições do dispositivo de entrada & $\begin{array}{c}\text { Total ou } \\
\text { parcialmente } \\
\text { Obstruído }\end{array}$ & $\begin{array}{l}\text { Limpo e } \\
\text { funcionando }\end{array}$ \\
\hline $\begin{array}{l}\text { Condições do corpo do reservatório de } \\
\text { detenção }\end{array}$ & Cheio & $\begin{array}{c}\text { Vazio ou } \\
\text { parcialmente } \\
\text { cheio* }\end{array}$ \\
\hline Condições do dispositivo de saída & Obstruído & Operante \\
\hline Condições do sistema de drenagem adjacente & $\begin{array}{c}\text { Parcialmente } \\
\text { obstruído, porém } \\
\text { funcionando }\end{array}$ & $\begin{array}{l}\text { Limpo e } \\
\text { funcionando }\end{array}$ \\
\hline Condições de acesso ao reservatório & Regular & Ruim \\
\hline Fidelidade ao projeto & Boa & Pouca \\
\hline Adequação do local de implantação & Apropriado & Apropriado \\
\hline Adequação do sistema proposto & Provável & Provável \\
\hline Manutenção dos reservatórios de detenção & Nenhuma & Boa \\
\hline $\begin{array}{lll}\text { Problemas com dimensionamento dos } \\
\text { dispositivos }\end{array}$ & Talvez & Pouco provável \\
\hline
\end{tabular}

\section{Continua}




\section{Continuação}

\begin{tabular}{|c|c|c|}
\hline Empreendimento & C.H. Itaquera C3 & C.H. Jaraguá H \\
\hline Qualidade da água que entra no sistema & Ruim & Aceitável \\
\hline $\begin{array}{l}\text { Atuação do reservatório no incremento da } \\
\text { qualidade da água }\end{array}$ & Pouca & Pouca \\
\hline $\begin{array}{l}\text { Possibilidade de operação do sistema } \\
\text { conforme projetado }\end{array}$ & Sim & Não \\
\hline $\begin{array}{l}\text { Organização e participação dos moradores } \\
\text { nos assuntos condominiais }\end{array}$ & Ruim & Boa \\
\hline Aceitação dos reservatórios pelos moradores & Não & Provável \\
\hline $\begin{array}{l}\text { Compreensão do sistema projetado pelos } \\
\text { executores (obras) }\end{array}$ & Sim, com ressalva & Não \\
\hline $\begin{array}{l}\text { Compreensão da finalidade dos reservatórios } \\
\text { pela população }\end{array}$ & Nenhuma & Pouca \\
\hline Impacto visual dos reservatórios & Baixo & Nenhum \\
\hline Integração dos reservatórios ao ambiente & Sim & Sim \\
\hline Necessidade de intervenção local & Sim & Sim \\
\hline $\begin{array}{l}\text { Possibilidade futura de alcançar os objetivos } \\
\text { propostos }\end{array}$ & Sim & Provável \\
\hline $\begin{array}{l}\text { Possibilidade de sobreposição de hidrogramas } \\
\text { nos sistemas de drenagem a jusante }\end{array}$ & Pouca & Sim \\
\hline $\begin{array}{l}\text { Expectativa dos moradores quanto a } \\
\text { possibilidade de aproveitamento múltiplo dos } \\
\text { reservatórios }\end{array}$ & Nenhuma & Sim \\
\hline $\begin{array}{l}\text { Reconhecimento da importância dos } \\
\text { reservatórios pelos moradores }\end{array}$ & Não & Pouca \\
\hline
\end{tabular}

*= por vontade dos próprios moradores. 
Tabela 36- Questionamentos principais quanto aos reservatórios de detenção: Planejamento

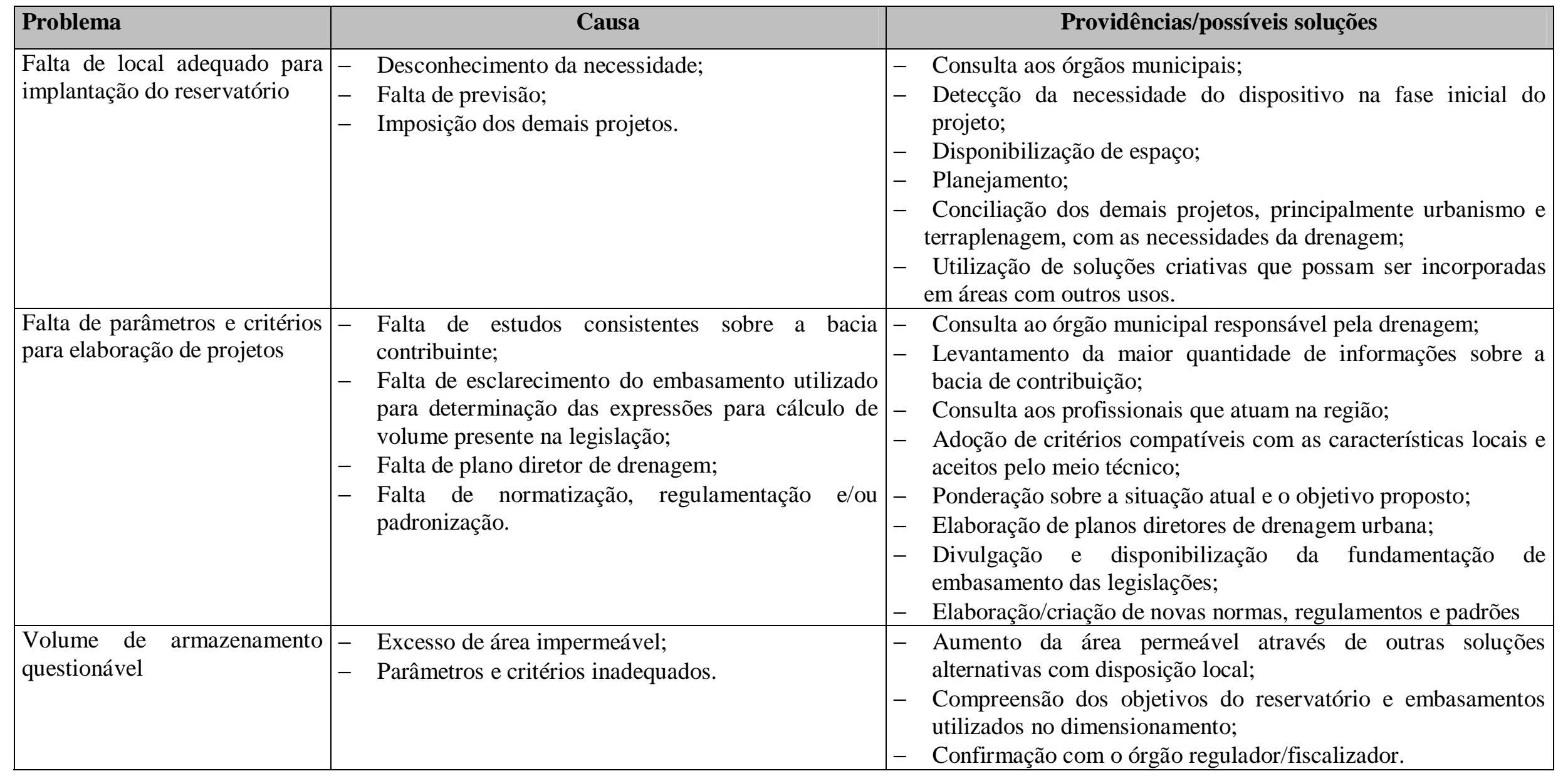


Tabela 37- Questionamentos principais quanto aos reservatórios de detenção: Projeto e Execução

\begin{tabular}{|c|c|c|}
\hline Problema & Causa & Providências/possíveis soluções \\
\hline $\begin{array}{l}\text { Projeto inadequado para o } \\
\text { local de implantação }\end{array}$ & 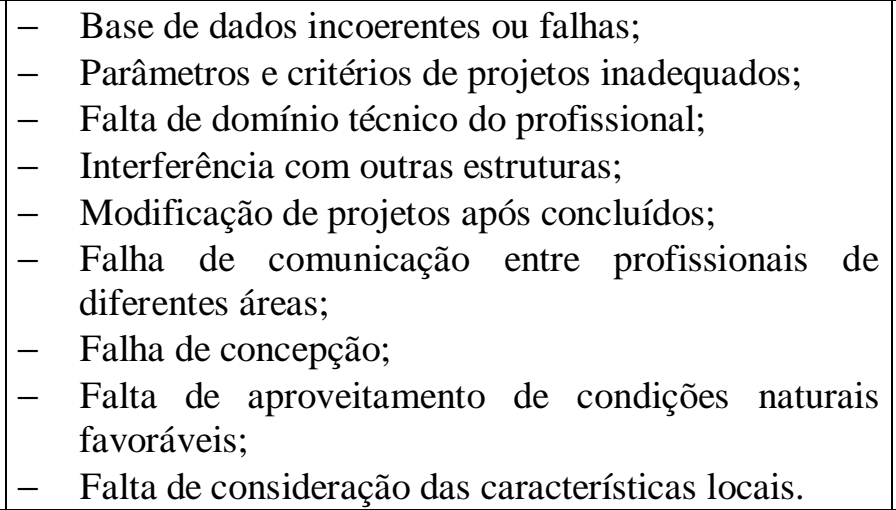 & $\begin{array}{ll}\text { - } & \text { Utilizaç̧ão de base de dados atualizadas e completas; } \\
\text { - } & \text { Confirmação dos parâmetros e critérios a serem adotados com } \\
& \text { os órgãos competentes; } \\
\text { - } & \text { Revisão, adequação e compatibilização do projeto do } \\
& \text { reservatório com os demais projetos; } \\
\text { - } & \text { Criação de ambientes propícios ao diálogo entre profissionais; } \\
\text { - } & \text { Reciclagem e atualização profissional; } \\
\text { - } & \text { Fiscalização rigorosa da locação e terraplenagem da obra. } \\
\text { - } & \text { Verificação das condições naturais existentes e dos problemas } \\
& \text { apresentados na bacia de contribuição; } \\
\text { - } & \text { Observação dos costumes e hábitos da população. }\end{array}$ \\
\hline $\begin{array}{l}\text { Execução em desacordo com o } \\
\text { projeto }\end{array}$ & $\begin{array}{ll}\text { - } & \text { Projeto não adequado à realidade; } \\
\text { - } & \text { Falta de compreensão do sistema projetado; } \\
\text { - } & \text { Dificuldade de execução ou leitura do projeto; } \\
\text { - } & \text { Desatenção da fiscalização. }\end{array}$ & $\begin{array}{ll}\text { - } & \text { Identificação da interferência e revisão ou modificação do } \\
& \text { projeto; } \\
\text { - } & \text { Busca de soluções simples; } \\
\text { - } & \text { Domínio da tecnologia; } \\
\text { - } & \text { Melhoria do memorial descritivo e dos elementos gráficos que } \\
& \text { compõem o projeto; } \\
\text { - } & \text { Apresentação do projeto aos encarregados de sua execução, } \\
& \text { enquanto os reservatórios forem elementos inovadores; } \\
\text { - } & \text { Verificação da conformidade da construção com o projeto. }\end{array}$ \\
\hline $\begin{array}{l}\text { Falta de preparo profissional } \\
\text { para desenvolver projetos de, } \\
\text { ou com, reservatórios }\end{array}$ & 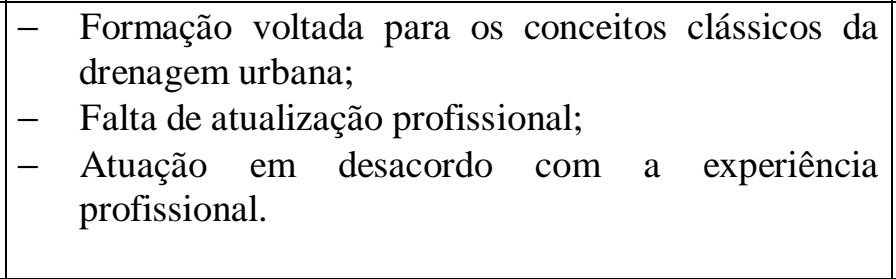 & 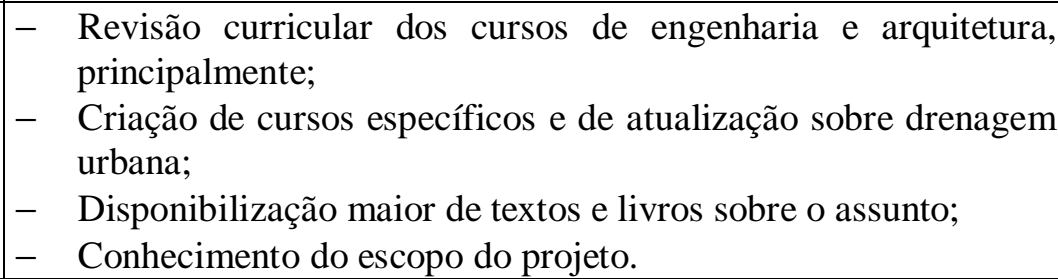 \\
\hline
\end{tabular}


Tabela 38- Questionamentos principais quanto aos reservatórios de detenção: Falhas Físicas

\begin{tabular}{|c|c|c|}
\hline Problema & Causa & Providências/possíveis soluções \\
\hline Obstrução do sistema & $\begin{array}{ll}- & \text { Acúmulo de lixo; } \\
\text { - } & \text { Falta de manutenção; } \\
\text { - } & \text { Falha estrutural ou de equipamento; } \\
\text { - } & \text { Projeto pouco cauteloso. }\end{array}$ & $\begin{array}{ll}\text { - } & \text { Aumento, melhora ou implementação de coleta regular de lixo; } \\
\text { - } & \text { Incentivo à reciclagem com ganhos revertidos à comunidade; } \\
\text { - } & \text { Conscientização e orientação à população; } \\
\text { - } & \text { Implementação de programas de limpeza, inspeção e } \\
& \text { manutenção regular; } \\
\text { - } & \text { Reparo estrutural ou conserto de equipamentos; } \\
\text { - } & \text { Implementação, reforço ou mudança no sistema de coleta de } \\
& \text { resíduos do reservatório (gradeamento, cestos, etc.); } \\
- & \text { Controle das atividades que geram resíduos no perímetro da } \\
& \text { bacia de contribuição; } \\
- & \text { Previsão de fundo permeável ou parcialmente permeável para } \\
& \text { que não haja acúmulo de água por período prolongado que } \\
& \text { possa trazer riscos à saúde da população; } \\
- & \text { Proteção principalmente dos dispositivos de entrada e saída do } \\
& \text { reservatório. }\end{array}$ \\
\hline Estruturas danificadas & $\begin{array}{ll}- & \text { Uso incorreto; } \\
\text { - } & \text { Falta de manutenção; } \\
\text { - } & \text { Vandalismo; } \\
\text { - } & \text { Erro de projeto ou execução. }\end{array}$ & $\begin{array}{ll}\text { - } & \text { Verificação das condições de entrega da estrutura; } \\
\text { - } & \text { Criação de manual de uso e operação; } \\
\text { - } & \text { Implementação de programas de inspeção e manutenção } \\
& \text { preventivas; } \\
\text { - } & \text { Conscientização e orientação à população; } \\
\text { - } & \text { Reforço e proteção das estruturas; } \\
\text { - } & \text { Averiguação e reparo das falhas de projeto ou de execução. }\end{array}$ \\
\hline
\end{tabular}


Tabela 39 - Questionamentos principais quanto aos reservatórios de detenção: Operação e Manutenção

\begin{tabular}{|c|c|c|}
\hline Problema & Causa & Providências/possíveis soluções \\
\hline Operação inadequada & $\begin{array}{ll}- & \text { Desconhecimento do sistema; } \\
\text { - } & \text { Descontentamento com o sistema proposto; } \\
\text { - } & \text { Falta de orientação; } \\
\text { - } & \text { Forma de operação difícil ou complicada; } \\
\text { - } & \text { Falta de responsável pela atividade; } \\
\text { - } & \text { Falta de recursos humanos e financeiros. }\end{array}$ & $\begin{array}{ll}\text { - } & \text { Elaboração, disponibilização ou revisão do manual de operação } \\
& \text { do sistema; } \\
\text { - } & \text { Adequação e melhoramento do sistema para atendimento das } \\
& \text { necessidades e/ou ansiedades da população; } \\
\text { - } & \text { Organização de reuniões de esclarecimentos e orientação; } \\
\text { - } & \text { Adoção de dispositivos simples e comuns, preferencialmente } \\
& \text { que opere sem intervenção humana; } \\
\text { - } & \text { Designação de pessoa ou órgão responsável pela atividade; } \\
\text { - } & \text { Criação de incentivos fiscais e previsão orçamentária; } \\
- & \text { Revisão de projetos e execução dos acertos necessários; } \\
\text { - } & \text { Fiscalização eficiente durante a fase de execução. }\end{array}$ \\
\hline Falta ou falha de manutenção & 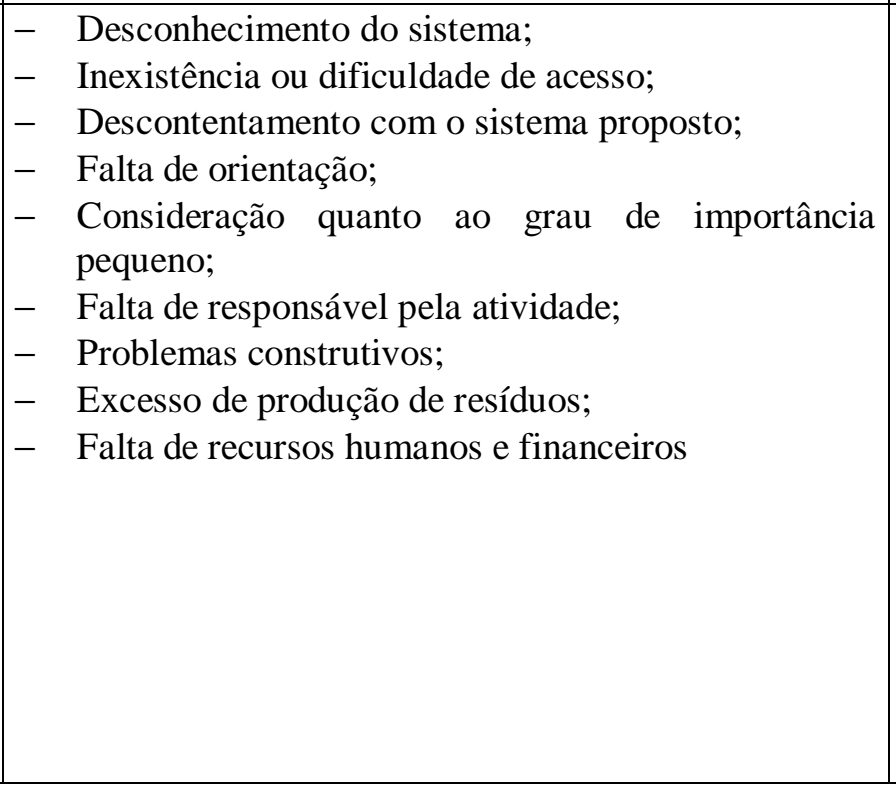 & 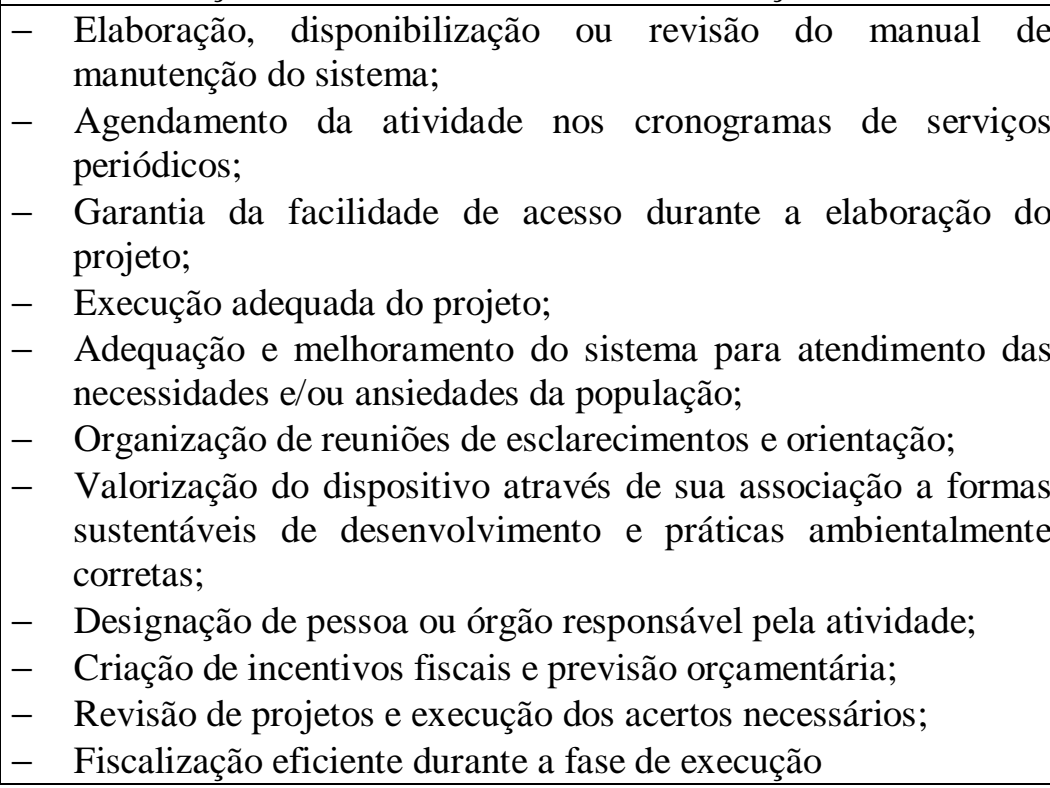 \\
\hline
\end{tabular}


Tabela 40 - Questionamentos principais quanto aos reservatórios de detenção: Meio ambiente e Segurança

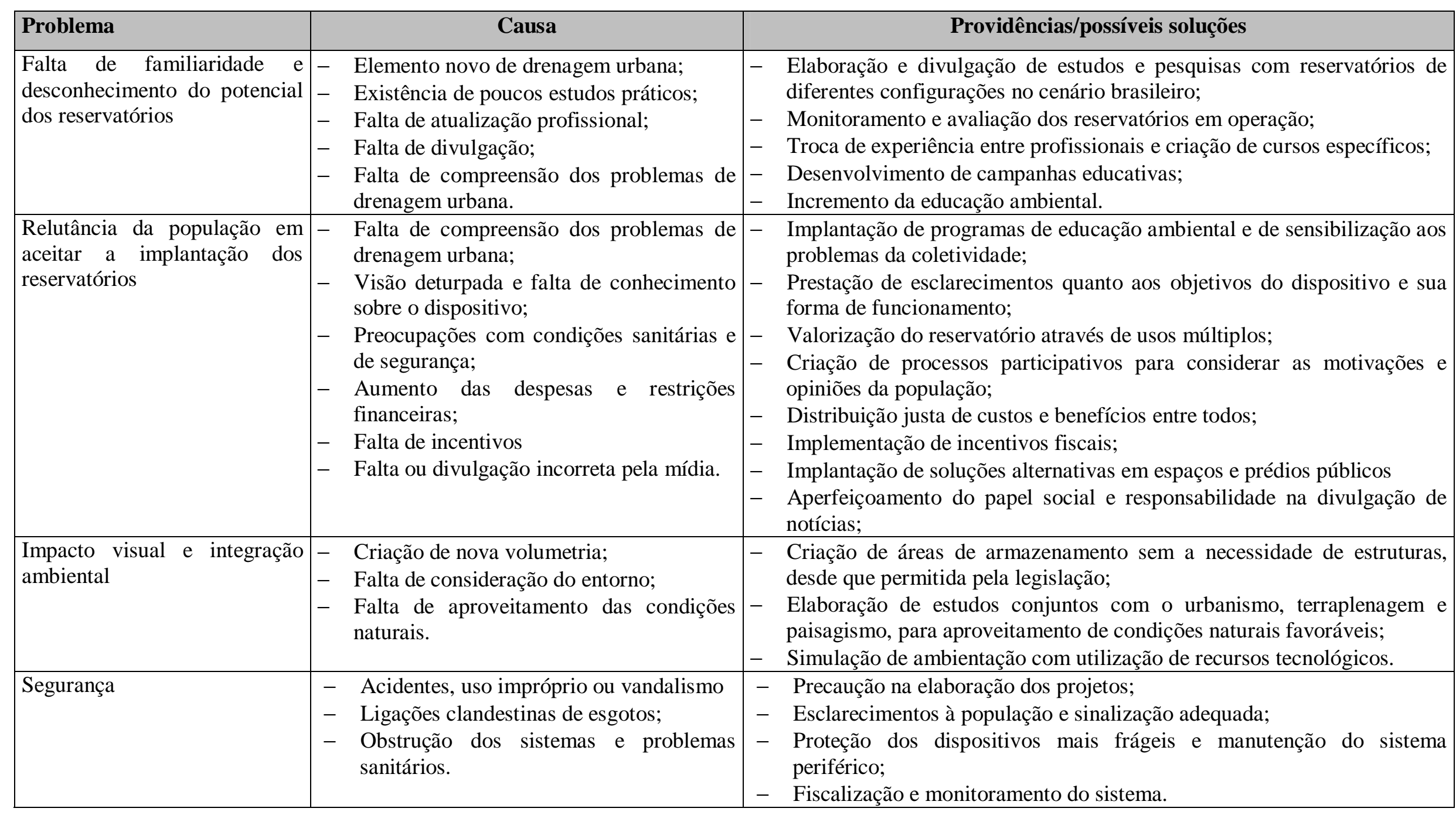




\subsection{Planejamento}

O planejamento é uma ferramenta fundamental para a drenagem urbana e é definido pela CETESB (1986) como a "atividade destinada a resolver os problemas de uma comunidade, através de soluções para um determinado local e período de tempo.

Pode-se dizer que o sistema de drenagem é conseqüência da existência ou não de planejamento em uma bacia hidrográfica, pois é ele que estabelece as linhas principais de conduta, ordena o desenvolvimento urbano e as formas de intervenções, estabelecendo as condições de relacionamento do homem com o meio ambiente.

"Os impactos urbanos que ocorrem na drenagem são, em primeiro lugar, consequiência direta das práticas de uso do solo e da forma pela qual a infra-estrutura urbana é planejada, legislada e implementada" (NETTO, 2003). A falta de planejamento associada a políticas inadequadas do ponto de vista quantitativo e qualitativo são responsáveis por grande parte dos problemas urbanos.

Modernamente, o planejamento e a ocupação do espaço urbano devem ser encarados como um problema gerencial e, embora envolva fundamentos interdisciplinares, nem sempre é elaborado ou definido com a participação de profissionais ligados aos recursos hídricos. Na prática é realizado dentro de um âmbito mais restrito do conhecimento, trazendo grandes transtornos e custos para a sociedade e para o meio ambiente (TUCCI e MARQUES, 2000).

"No Brasil enfrenta-se mal a questão do planejamento a nível nacional. De forma geral, não se planejam as cidades" (WILHEIM, 1998) e soluções improvisadas ou ações de remediações são solicitadas e implantadas quando já existe uma situação indesejada. Infelizmente, o processo de "pensar" as cidades não tem sido realizado de forma sistemática e coerente ao longo dos últimos anos, justamente quando foi intenso o processo brasileiro de urbanização (NETTO, 2003).

A falta de consideração da drenagem desde o início da formulação do planejamento urbano, provavelmente conduzirá a sistemas que são, ao mesmo tempo, de alto custo e ineficientes (CETESB, 1986). 
Independentemente das características da drenagem a ser implantada em uma bacia hidrográfica, é fundamental que seja feito seu planejamento através de planos diretores de drenagem urbana para que possibilite a uniformização dos procedimentos de análises hidráulicas e hidrológicas e a criação de sistemas lógicos, organizados e com reais possibilidades de atingir os objetivos propostos; ao mesmo tempo, evita-se medidas inadequadas, priorizando atitudes harmônicas e conformes com as metas da totalidade da bacia hidrográfica.

PARKINSON et al (2003) enumeram na tabela 41, os problemas da estrutura organizacional e institucionais relacionados à drenagem urbana, nas diferentes esferas políticas, assim como suas causas e possíveis soluções, indicando caminhos para melhorar e/ou viabilizar o planejamento ${ }^{132}$.

Para TASSI (2002), o procedimento correto para o controle dos volumes excedentes gerados pela urbanização é o planejamento integrado e abrangente dos sistemas de drenagem, visando a solução dos conflitos para os quais o planejador deve dar respostas apropriadas. CANHOLI (2000) observa que o maior desafio dos planejadores e administradores dos grandes centros urbanos no mundo é a análise e o encaminhamento dessas questões.

Ainda segundo CANHOLI (1995), “faz-se necessária a realização de estudos de planejamento global de drenagem urbana, onde todos os aspectos voltados às obras de infra-estrutura e de planejamento urbano, sejam analisados de forma integrada", pois "quanto maior for a compreensão entre as relações espaço urbano/ciclo hidrológico, maior será o potencial do planejamento em minimizar os impactos" (PARKINSON et al, 2003).

\footnotetext{
${ }^{132}$ No município e estado de São Paulo, alguns desses problemas já estão sendo encaminhados através da própria PMSP, da SIURB, do Metrô e do DAEE, segundo informações do Dr. Rubens Terra Barth.
} 
Tabela 41 - Problemas de estrutura organizacional e institucional

\begin{tabular}{|c|c|c|}
\hline Problema & Causa & Possível solução \\
\hline \multicolumn{3}{|c|}{ Municipal } \\
\hline $\begin{array}{l}\text { Inexistência de equipe } \\
\text { técnica }\end{array}$ & $\begin{array}{l}\text { Volume de trabalho } \\
\text { insuficiente }\end{array}$ & $\begin{array}{l}\text { Formação de consórcios } \\
\text { intermunicipais ou assemelhados }\end{array}$ \\
\hline $\begin{array}{l}\text { Inadequação técnica } \\
\text { das equipes }\end{array}$ & $\begin{array}{lr}\text { Carência } & \mathrm{de} \\
\text { investimentos } & \mathrm{em} \\
\text { formação e atualização }\end{array}$ & $\begin{array}{l}\text { Definição de política de } \\
\text { treinamento e atualização }\end{array}$ \\
\hline $\begin{array}{l}\text { Desconhecimento dos } \\
\text { sistemas existentes }\end{array}$ & $\begin{array}{l}\text { Falta de investimentos } \\
\text { em cadastro e gestão } \\
\text { patrimonial }\end{array}$ & $\begin{array}{l}\text { Disponibilização de recursos } \\
\text { financeiros, materiais e humanos } \\
\text { para elaboração e gestão de } \\
\text { cadastros }\end{array}$ \\
\hline $\begin{array}{l}\text { Pouco conhecimento } \\
\text { dos processos físicos } \\
\text { envolvidos }\end{array}$ & $\begin{array}{lr}\text { Inadequação } & \mathrm{de} \\
\text { investimentos } & \mathrm{em} \\
\text { monitoramento } & \end{array}$ & $\begin{array}{l}\text { Disponibilização de recursos } \\
\text { financeiros, materiais e humanos } \\
\text { para execução de monitoramentos }\end{array}$ \\
\hline $\begin{array}{|lrr|}\text { Fragilidade } & \text { do } & \text { setor } \\
\text { responsável } & & \text { pela } \\
\text { drenagem } & & \\
\end{array}$ & $\begin{array}{l}\text { Falta de autonomia, } \\
\text { recursos e continuidade } \\
\text { administrativa }\end{array}$ & $\begin{array}{l}\text { Instituição de órgão gestor com } \\
\text { autonomia gerencial e financeira }\end{array}$ \\
\hline $\begin{array}{ll}\text { Fragmentação } & \mathrm{e} \\
\text { duplicação de ações } & \end{array}$ & $\begin{array}{l}\text { Multiplicidade de atores } \\
\text { e inadequação do fluxo } \\
\text { de informações }\end{array}$ & $\begin{array}{l}\text { Instituição de órgão gestor com } \\
\text { autonomia gerencial e financeira }\end{array}$ \\
\hline \multicolumn{3}{|c|}{ Regional } \\
\hline \begin{tabular}{|l|} 
Tratamento inadequado \\
der questões \\
intermunicipais
\end{tabular} & $\begin{array}{l}\text { Abordagem } \\
\text { estritamente municipal } \\
\text { dos problemas }\end{array}$ & $\begin{array}{l}\text { Formação de consórcios } \\
\text { intermunicipais ou assemelhados }\end{array}$ \\
\hline \multicolumn{3}{|c|}{ Municipal, estadual e federal } \\
\hline $\begin{array}{l}\text { Deficiência na estrutura } \\
\text { jurídica }\end{array}$ & $\begin{array}{l}\text { Carência } \\
\text { formalização } \\
\text { necessidades }\end{array}$ & $\begin{array}{l}\text { Revisão e adequação do } \\
\text { arcabouço jurídico }\end{array}$ \\
\hline
\end{tabular}

(Fonte: PARKINSON et al, 2003 - modificado) 
PARKINSON (site) comenta que os avanços tecnológicos proporcionam ferramentas para o planejamento e para elaboração de projetos, mas para que os sistemas de drenagem sejam economicamente viáveis e operacionalmente sustentáveis, é necessário enfatizar os seguintes pontos:

- coordenação entre autoridades e agências responsáveis pelos diferentes aspectos da implantação e manutenção dos sistemas;

- colaboração entre organizações governamentais e não-governamentais para promover parcerias com a sociedade civil e o setor privado;

- treinamento e desenvolvimento de recursos humanos para melhorar o planejamento, projeto, operação e manutenção dos sistemas de drenagem.

Assim, o planejamento é a principal solução para a desorientação vivida pelos profissionais da área no desenvolvimento de seus trabalhos, assim como fonte principal para a ponderação sobre a necessidade ou não de legislações específicas e balizamento do seu conteúdo.

Pontos considerados primordiais dentro do planejamento da drenagem urbana, com potencial para melhorar a utilização dos reservatórios de detenção e de outras formas alternativas de controle de cheias são apresentados a seguir.

\subsubsection{Comitês de bacias hidrográficas}

Os Comitês de Bacias Hidrográficas são órgãos colegiados, consultivos e deliberativos, inteiramente novos na realidade institucional brasileira, que contam com a participação dos usuários, da sociedade civil organizada, de representantes de governos municipais, estaduais e federal, e são destinados a atuar como "parlamento das águas", posto que são o fórum de decisão no âmbito de cada bacia hidrográfica (MMA, 2004).

Eles foram criados para propiciar maior integração no planejamento, na organização, nas formas de regulamentação do uso e ocupação do solo e na aplicação de recurso das bacias hidrográficas, e o seu correto gerenciamento, vetor de 
desenvolvimento através do ordenamento e integração político-institucional e da correta concepção, operação e manutenção dos sistemas.

Entretanto vale lembrar que "a simples presença municipal na composição desses comitês de bacia hidrográfica não é suficiente para resolver todos os complexos problemas que existem na articulação entre os objetivos de sustentabilidade da bacia em seu conjunto e de desenvolvimento de cada um dos municípios" (CBH-AT, 2002).

Questões específicas de interesse local não tem como ser debatidas em toda sua amplitude no escopo do Comitê de Bacia e de seu Plano e não cabe ao Estado agir como"protagonista" na adequação da legislação e das práticas administrativas municipais aos objetivos e metas ambientais desses planos, mas antes exercer um papel cooperativo e "tutelar", orientando e apoiando a criação de instrumentos inovadores e apropriados pelos municípios, através de incentivos externos articulados a medidas de supervisão e acompanhamento (CBH-AT, 2002).

TUCCI e MARQUES (2000) concordam que a administração da drenagem urbana é realizada pelos municípios e que estes, por não possuírem suporte técnico neste assunto, acabam adotando soluções inadequadas que transferem ou agravam os problemas existentes, sem considerar a bacia hidrográfica e a custos muito altos.

Existe evidentemente a necessidade de uma estrutura institucional que propicie esse suporte técnico para as cidades de pequeno porte, pois estas não possuem condições de manutenção de equipes técnicas para tratar convenientemente os problemas de drenagem (PARKINSON et al, 2003).

Como os Comitês de Bacias hidrográficas costumam contar com corpos técnicos gabaritados ${ }^{133}$, inclusive representantes de universidades e institutos de pesquisas, pode-se incluir entre suas atividades, a assistência técnica a essas prefeituras carentes, ajudando-as a solucionar seus problemas de drenagem ou mesmo auxiliando no estabelecimento de critérios e parâmetros mínimos para desenvolvimento dos seus sistemas.

Essa possível função, a ser aperfeiçoada com a criação das Agências das Águas, visto que funcionarão como braço técnico dessas organizações, fomenta não

\footnotetext{
133 O Comitê de Bacia do Alto Tietê, por exemplo, conta também com uma câmara técnica de drenagem.
} 
somente a conduta conforme dos Municípios, como também a integração e o desenvolvimento correto das soluções encaminhadas.

Nesta troca há ganhos de ambas as partes: o Comitê de Bacia ao aumentar o grau de adesão dos Municípios, harmonizar procedimentos e alcançar seus objetivos e as prefeituras pelo ganho administrativo, qualidade da consultoria técnica e equacionamento correto de seus problemas.

Porém, reconhece-se as dificuldades já enfrentadas pelos Comitês de Bacias e as limitações de seu desempenho, até mesmo pela implantação incompleta dos Sistemas de Gerenciamento de Recursos Hídricos e os diferentes graus de organização e participação verificado nas diversas bacias hidrográficas, observando a necessidade de fortalecimento urgente dessas instituições.

Pesquisa qualitativa encabeçada pela Secretaria do Meio Ambiente do Estado de São Paulo em 1996, realizada junto aos dezoito Comitês de Bacia então existentes, apontou as principais dificuldades encontradas por eles: falta ou indisponibilidade de recursos financeiros para custeio das atividades, carência de pessoal qualificado nas diferentes especialidades requeridas, sobrecarga de trabalho na secretaria executiva, falta de apoio técnico adequado por parte do CORHI e ausência de dados confiáveis e/ou atualizados (CBH-AT, 2002).

Apesar das carências observadas, entende-se que os Comitês de Bacias ainda são as instituições adequadas para desempenhar a função de assessor técnico dos Municípios, sem a necessidade de criação de mais um órgão público, pois têm papel fundamental para aumento da credibilidade e da qualidade na drenagem urbana, ao mesmo tempo em que são órgãos capazes de lidar com a grande diversidade regional e suas questões específicas.

\subsubsection{Planos diretores}

O Plano Diretor ou Plano Diretor de Desenvolvimento Integrado é o conjunto de normas legais e diretrizes técnicas para o desenvolvimento global e constante, sob os aspectos físico, social, econômico e administrativo, desejado pela comunidade local. Deve expressar as aspirações da população quanto ao progresso do território no 
seu conjunto e é o instrumento técnico-legal definidor dos objetivos e, por isso, "com supremacia sobre os outros, para orientar toda atividade da Administração e dos administrados nas realizações públicas e particulares que interessem ou afetem a coletividade" (MEIRELLES, 1994 apud QUADROS, 2001).

O plano diretor tem o objetivo de orientar como se pretende tratar o município, o estado ou o país, possibilitando a reflexão sobre os caminhos a serem percorridos para alcançar o desenvolvimento desejado e quais são suas implicações. Seu detalhamento pode variar desde uma intenção até o estabelecimento de índices, manchas de detalhamento e, principalmente nos dias de hoje, possibilitar parcerias para viabilização e obtenção de recursos, além de direcionar investimentos. Tem ainda embutido em seus conceitos, a tarefa primordial de conscientizar e ajudar na formação da cidadania, através da participação das comunidades organizadas, que por sua vez tem o dever fundamental de zelar pela criação do seu próprio meio ambiente, ao mesmo tempo em que preserva seus recursos naturais e culturais.

O planejamento explicitado deve conduzir sempre a soluções exeqüíveis, técnica e economicamente eficientes, coerentes com os demais planos setoriais, aplicáveis a toda área de sua abrangência e sobretudo, expressar os consensos firmados de acordo com os anseios da sociedade.

É importante também, que esses Planos contemplem práticas de avaliação que permitam identificar as condições efetivas de vigência dos instrumentos legais nos municípios integrantes da bacia e não fiquem apenas na contabilização de sua existência formal. Além disso, devem incorporar instrumentos que favoreçam a resolução de conflitos de interesses e forneçam suporte à decisão, facilitando a escolha das melhores alternativas (CBH-AT, 2002).

A forma correta de elaboração de um plano diretor é sem dúvida, a discussão multidisciplinar de todos os temas, porém essa integração nem sempre é alcançada, ficando cada grupo restrito aos seus assuntos particulares, postergando a união necessária para viabilização das várias propostas.

A CETESB (1986) ressalta que a presença de um engenheiro hidráulico é fundamental na equipe multidisciplinar responsável pela formulação dos planos diretores, ao lado de urbanistas, economistas, sociólogos, paisagistas, etc. 
Estudos feito por TUCCI e MARQUES (2001) sobre a diferente influência de índices urbanísticos de uso e de ocupação do solo presentes em alguns dos planos diretores existentes na geração de áreas livres (tabela 42), por exemplo, demonstram a conveniência de considerar uma variável hidrológica na determinação da utilização do solo frente a grande variação percentual dos valores obtidos e a necessidade de controlar a impermeabilização dessas superfícies.

Tabela 42 - Valores médios de áreas livres dos planos diretores

\begin{tabular}{|l|c|c|}
\hline \multirow{2}{*}{ Planos diretores } & \multicolumn{2}{|c|}{ Áreas livres (\%) $^{2}$} \\
\cline { 2 - 3 } Porto Alegre (vigente) & 64 & 34 \\
\hline Porto Alegre (aprovado) & 34 & 17 \\
\hline Florianópolis & 68 & 66 \\
\hline Goiânia & 78 & 56 \\
\hline Campinas do Uso & Maximização da Ocuãa $^{135}$ \\
\hline Belo Horizonte & 71 & 35 \\
\hline
\end{tabular}

(Fonte: TUCCI e MARQUES, 2001)

Segundo SICKERMANN (2001), "a maioria dos municípios baixou normas a respeito da parcela de um lote a ser deixada livre (taxas de ocupação entre 15 e 50\%), porém estas são ainda largamente descumpridas" e "é possível estabelecer um percentual mínimo de área permeável no lote porque algum controle desse parâmetro pode ser realizado na aprovação de imóveis novos, porém o avanço posterior da impermeabilização sobre o lote é virtualmente incontrolável” (CBH-AT, 2002).

O próprio Governo Federal reconhece que "a maioria dos municípios, prefeitos, técnicos e sociedade civil ainda não estão preparados para discutir, elaborar e implementar Planos Diretores com a participação da sociedade, onde o uso da terra

\footnotetext{
${ }^{134}$ valor máximo de área construída em forma de pavimentos - aproveitamento, segundo as restrições impostas pelos índices dos planos diretores

${ }^{135}$ valor máximo de área construída associados a maior projeção horizontal do edifício sobre o terreno, dentro das restrições pertencentes a cada plano
} 
urbana atenda o interesse coletivo, ou seja, que o plano diretor estabeleça a função social da propriedade e da cidade" (MCIDADES, site).

Canholi (2000) situa o plano diretor de drenagem urbana como elemento imprescindível para disciplinar e controlar as inundações de uma bacia, porém ressalta que esforço maior deve ser direcionado na condução e elaboração do mesmo para "que não se torne meramente um plano de obras, mas sim um instrumento regulador, referencial técnico e estratégico que condicione as intervenções dos municípios e ao mesmo tempo defina os instrumentos políticos, institucionais e econômico-financeiros de viabilização, no contexto das ações estruturais e não estruturais necessárias às melhorias dos sistemas de drenagem urbana”.

Além disso, as ações devem ser pré-dimensionadas sob procedimentos uniformes de análise hidráulica e hidrológica, hierarquizadas sob os pontos de vista técnico, econômico e ambiental, possibilitando a harmonização entre ações dos vários órgãos das administrações federal, estaduais e municipais, e das concessionárias responsáveis pelo gerenciamento da drenagem urbana nos vários municípios.

De maneira conceitual, as premissas básicas a serem consideradas na formulação de um plano diretor são:

- A drenagem é um fenômeno regional: a unidade de gerenciamento é a bacia hidrográfica;

- A drenagem é um questão de alocação de espaços: a supressão de áreas de inundação, naturais ou não, implicará na sua relocação a jusante;

- A drenagem é parte integrante da infra-estrutura urbana: o seu planejamento deve ser multidisciplinar e compatível com os demais planos e projetos dos demais setores;

- A drenagem deve ser sustentável: seu gerenciamento deve garantir a sustentabilidade institucional, ambiental e econômica;

- A drenagem urbana não deve se restringir aos fenômenos hidráulicos: deve considerar também critérios ambientais, sociais e econômicos; 
- As medidas de controle da poluição são essenciais para o desempenho adequado da drenagem: deve ser dada atenção aos aspectos da qualidade da água para que sejam alcançados os objetivos propostos.

As limitações técnicas para o desenvolvimento de um plano diretor de drenagem urbana e funcionamento dos sistemas de drenagem são, segundo PARKINSON et al (2003):

- Conhecimento precário dos sistemas de drenagem existentes, seu estado de conservação e suas condições operacionais;

- Custos elevados para levantamento de dados e estruturação dos cadastros ${ }^{136}$;

- Falta de capacitação do corpo técnico, de cultura de planejamento e manutenção, e de recursos humanos e financeiros;

- Precário conhecimento dos processos hidrológicos e do funcionamento hidráulico dos sistemas implantados, pela inexistência ou insuficiência de monitoramento e cadastros ${ }^{137}$;

- Inadequação estrutural de equipes técnicas e gerencias municipais para desenvolvimento ou análise dos planos diretores.

TUCCI e MARQUES (2001), observam que as ações da sociedade somente contrariam um planejamento adequado quando os mesmos são irreais ou a população é mal informada sobre suas conseqüências, como acontece na drenagem.

Segundo MEDEIROS (1999), "os processos de planejamento de cunho participativo, como alternativa aos modelos tradicionais, constituem um poderoso instrumento contrabalanceador das tendências corporativas e clientelistas vigentes nos padrões tradicionais de representação política".

Entretanto, "embora a substituição de estruturas institucionais seja um passo muito importante na direção de uma democratização do aparelho do estado, ela por si só não é suficiente para uma aproximação entre o estado e a sociedade", havendo a

\footnotetext{
${ }^{136}$ Aproximadamente $\mathrm{R} \$ 300,00 /$ ha de área urbana, podendo ser reduzido com economia de escala. ${ }^{137}$ Item a ser melhorado nos Planos Diretores de SP (grande esforço, pequeno resultado), segundo informações do Dr. Rubens Terra Barth.
} 
necessidade de institucionalização das práticas de participação popular, garantindo assim um diálogo efetivo entre o governo e as forças populares.

"É importante reconhecer que o planejamento é um processo social. Considerar o planejamento como um exercício mecânico e analítico, sem a devida consideração pelo contexto social é incorrer em erro impossível de remediar, bem como inviabilizar tanto o esforço de planejamento quanto a sua implementação" (PMSP/FCTH, 1999).

Desta forma, os planos diretores são peças chaves na definição das situações onde os reservatórios de detenção serão utilizados, no fornecimento de parâmetros e critérios de dimensionamento, na precaução contra efeitos adversos e no desenvolvimento de um ambiente propício para sua efetivação.

\subsubsection{Políticas fiscais}

Políticas fiscais para drenagem urbana, como taxas de melhoria, descontos para incentivos de práticas de conservação, etc., estão em plena discussão no meio técnico e buscam fomentar sustentabilidade e autonomia para criação de sistemas apropriados de gestão de recursos hídricos na esfera das bacias hidrográficas.

De forma geral nos dias atuais, o orçamento municipal suporta a implantação, ampliação, manutenção e gestão dos sistemas de drenagem, embora não haja mecanismo indutor que garanta recursos para estas aplicações.

A inadequação dos recursos alocados na drenagem urbana reflete, não somente a insuficiência de investimentos que compromete a execução de obras e a manutenção dos sistemas, mas a fragilidade da estrutura organizacional que transparece na inadequação da formação de equipes técnicas, na redundância de órgãos gestores, na descontinuidade administrativa e na ausência de planejamento.

Assim, "para assegurar a operação sustentável dos sistemas de drenagem, novos métodos de planejamento e gerenciamento urbano são necessários" (PARKINSON et al, 2003).

A tabela 43 apresenta algumas modalidades de financiamento possíveis para a drenagem urbana, suas características básicas e seus impactos, onde observa-se que a 
taxa de impermeabilização é a mais interessante e viável, pelo seu embasamento físico e caráter incitativo para controle do escoamento superficial gerado, apesar de não estar devidamente amparada pela legislação vigente.

Tabela 43 - Modalidades de financiamento

\begin{tabular}{|l|c|c|c|c|c|c|}
\hline \multirow{2}{*}{$\begin{array}{l}\text { Modalidade de } \\
\text { financiamento }\end{array}$} & \multicolumn{3}{|c|}{ Características básicas } & \multicolumn{2}{c|}{ Impactos } \\
\cline { 2 - 7 } & fisica & $\begin{array}{c}\text { Caráter } \\
\text { incitativo }\end{array}$ & Equidade & $\begin{array}{c}\text { Facilidade } \\
\text { técnica de } \\
\text { implantação }\end{array}$ & $\begin{array}{c}\text { Legais e } \\
\text { políticos }\end{array}$ & $\begin{array}{c}\text { Opinião } \\
\text { pública }\end{array}$ \\
\hline Imposto específico & Possível & Possível & Possível & Sim & Forte & Forte \\
\hline $\begin{array}{l}\text { Taxa de } \\
\text { impermeabilização }\end{array}$ & Sim & Sim & Possível & Não & Forte & Médio \\
\hline $\begin{array}{l}\text { Cobrança de taxas pelas } \\
\text { agências de água }\end{array}$ & Possível & Possível & Possível & Possível & Médio & Médio \\
\hline $\begin{array}{l}\text { Cobrança acoplada ao } \\
\text { consumo de água }\end{array}$ & Não & Não & Não & Sim & Fraco & Forte \\
\hline $\begin{array}{l}\text { Desconto no IPTU para } \\
\text { manutenção de } \\
\text { reservatórios particulares }\end{array}$ & Sim & Sim & Possível & Sim & Médio & Fraco \\
\hline
\end{tabular}

(Fonte: PARKINSON et al, 2003 - modificado)

A cobrança pelo uso da água de forma geral, é considerada um instrumento de incentivo à racionalização do uso dos recursos hídricos, um mecanismo de fomento à programas de conservação, proteção e recuperação da qualidade das águas, e um dispositivo auxiliar para o disciplinamento da ocupação do solo nas bacias hidrográficas, e ao mesmo tempo visto pelos organismos internacionais como eficiente instrumento de gestão (COSTA e SANTOS, 1999) e (CBH-AT, 2002).

"No processo da formulação institucional mais ampla, essa atitude inovadora desdobra-se na concepção de um sistema de licenciamento e adesão progressiva de agentes, que acene com incentivos tangíveis a todos os que promovam o uso 
conforme dos recursos. Esses incentivos poderão traduzir-se tanto em redução nos preços de outorgas como no acesso facilitado a recursos para os programas que integram os planos da bacia" (CBH-AT, 2002).

Num plano de bacia por exemplo, o sistema de adesão e incentivos diz respeito a metas desejáveis, mas que por sua natureza não se caracterizam como objeto de imposição normativa, pois não se pode obrigar o município a investir seus recursos financeiros, fiscais e a capacidade de mobilização política em matérias de interesse direto dos planos, entretanto pode-se estabelecer um sistema de incentivos de forma tal que os que o fizerem sejam recompensados (CBH-AT, 2002).

A participação da pequena propriedade urbana no custeio da defesa contra as cheias pode ser mediada pelo estabelecimento de obrigações para as prefeituras a partir das vazões de restrição, ou medida similar, ficando a cargo das administrações municipais a decisão de como custear os investimentos necessários para o cumprimento dessas metas de vazão (CBH-AT, 2002).

"É importante observar que o sistema de adesão e incentivos não substitui a imposição e a fiscalização de atendimento às normas de cumprimento obrigatório. Estas continuam a ser objeto de regulação e fiscalização estritos, inclusive mediante melhoria da capacidade de fiscalização, contemplada como um dos principais componentes do desenvolvimento institucional necessário" (CBH-AT, 2002).

Outro ponto que requer atenção é a necessidade de integrar os instrumentos de licenciamento e outorga já existentes, pois os procedimentos de licenciamento ambiental, de uso do solo e de outorga na bacia, ainda são realizados de maneira independente e não integrada, desestimulando os empreendedores a cumprir esse conjunto de exigências em função da demora no atendimento e da pouca praticidade. É conveniente que o licenciamento de empreendimentos capazes de impactar o regime de cheias fique a cargo de um colegiado composto pelos órgãos do poder concedente e por representantes da sociedade civil organizada.

Entretanto, tratando-se de população de baixa renda, é necessário ponderar o alcance de tais medidas, uma vez que situação semelhante ao que acontece com as tarifas públicas de água e eletricidade ${ }^{138}$ poderá se repetir. O próprio Estatuto da

\footnotetext{
${ }^{138}$ Essas tarifas são subsidiadas e muitas vezes os serviços são recebidos gratuitamente.
} 
Cidade prevê que "os tributos sobre imóveis urbanos, assim como as tarifas relativas a serviços públicos urbanos, serão diferenciados em função do interesse social" ${ }^{\text {139 }}$.

Observa-se que o crescimento da população de baixa renda é fator limitante à cobrança pela impermeabilização e ao estabelecimento de obrigações pela provável necessidade de subsídio, que implica na priorização de parte dos participantes de uma bacia hidrográfica (por exemplo, conjuntos habitacionais de interesse social) como receptores de recursos de operações urbanas para viabilizar o atendimento às medidas implantadas e permitir simultaneamente, o crescimento urbano (CBH-AT, 2002).

Infelizmente, medidas econômicas parecem ser as mais eficientes na indução e criação de novos hábitos e alternativas, como foi e está sendo a "taxa do lixo" criada pela prefeitura de São Paulo.

A drenagem urbana, por seu caráter relativo na distribuição de custos e benefícios, que torna a conscientização um processo demorado e árduo, não tem como relegar o potencial deste tipo de instrumento e diante deste cenário, "a adequada atribuição de custos e benefícios no uso dos recursos hídricos tem papel central na definição de parâmetros equilibrados para o balizamento de negociações" (CBH-AT, 2002).

Nota-se portanto, que a cobrança pelo uso da água é um ponto controverso e crucial na gestão dos recursos hídricos e uma regulamentação inadequada poderá frustrar todas as expectativas até agora desenvolvida

Resta saber também, como estes objetivos serão alcançados sem que a mesma se torne meramente uma fonte adicional de arrecadação financeira para uma área particular do aparelho estatal/municipal (CBH-AT, 2002).

\subsection{Considerações Técnicas}

\subsubsection{Concepção, projeto e obras}

Historicamente, ao menos na CDHU, os engenheiros de infraestrutura como são chamados os profissionais que atuam em drenagem na área de projetos da

${ }^{139}$ Artigo 47. 
companhia, têm tido poucas possibilidades de intervenção na concepção dos projetos, uma vez que estes só tomam conhecimento dos empreendimentos quando a maioria dos projetos já se encontram consolidados ou em estado muito avançado para propor grandes modificações.

Isso se deve por um lado aos conceitos arraigados na empresa e a visão limitada dos profissionais do mercado, mas principalmente, ao exíguo tempo existente para desenvolvimento dos projetos, imposto pela necessidade de atendimento aos programas do governo e ao número reduzido de profissionais desta especialidade nos quadros da companhia.

$\mathrm{O}$ atendimento aos novos conceitos de drenagem urbana demanda equipes multidisciplinares, com a participação do engenheiro de infraestrutura desde as fases iniciais dos projetos e a conscientização dos urbanistas sobre seu papel fundamental no desenvolvimento destes sistemas.

Soluções de melhor qualidade podem ser desenvolvidas, se for possível prever a necessidade de implantação de reservatórios de detenção desde o início dos processos. Deve-se também, atentar para as oportunidades de implantação dos reservatórios de detenção, como no caso do Conjunto Habitacional Herculândia C.

É preciso estar atento às características locais e à dinâmica da bacia de contribuição, incluindo hábitos e costumes impróprios da sociedade, como lançamentos irregulares de esgoto e disposição inadequada do lixo. A qualidade da água também deve ser considerada para evitar agravamento das condições sanitárias devido às características do escoamento superficial.

Os futuros usuários dos reservatórios devem estar conscientes de sua finalidade e forma de funcionamento, além de serem alertados para a normalidade de parte dos eventos de extravasão do sistema. É necessário advertir que os sistemas de drenagem propiciam uma proteção relativa, atrelada ao custo dos sistemas e que os eventos hidrológicos são completamente imprevisíveis e ainda não controlados pelos homens.

Relativamente ao dimensionamento das estruturas, recomenda-se cautela, mesmo quando os volumes forem determinados por legislações específicas, pois estas determinarão apenas as dimensões do corpo de armazenamento e talvez, a 
vazão máxima desejada a jusante, sem condicionar as estruturas de entrada e de saída e os extravasores.

Como ainda não há uma normatização sobre este assunto, todas as variáveis são possíveis, e na maioria das vezes, as escolhas ficam a critério dos projetistas, que deverão se precaver dentro do arcabouço técnico e exemplos existentes.

Talvez a experiência brasileira não seja suficientemente extensa para edição de tal normatização, mas poderia haver um esforço no esboço de um anteprojeto de norma que pudesse orientar minimamente os profissionais e culminasse no seu texto definitivo.

Os estudos de casos apresentados neste trabalho, indicam que as estruturas de entrada e saída são extremamente sujeitas à obstrução, os extravasores são freqüentemente utilizados, o acesso para manutenção não deve ser negligenciado ${ }^{140}$, o sistema não deve depender de operação manual ou elétrica e que preocupações com a segurança e a qualidade da água devem estar sempre presentes.

Outra necessidade observada é a fidelidade ao projeto durante a execução e o acompanhamento/monitoramento do sistema para averiguação das suposições de projeto, de possíveis falhas ou solicitação de melhoramentos.

Além disso, a avaliação dos reservatórios implantados apresentada anteriormente, sinaliza que, por tratarem-se de medidas menos drásticas, sem necessidade de operação e com manutenção reduzida, em especial para o universo dos moradores dos conjuntos da CDHU, outras técnicas alternativas para redução do escoamento superficial, como aquelas almejadas pelas LID's, são muito mais adequadas do que formas clássicas de reservatórios de detenção, apesar de mais trabalhoso, sobretudo para os urbanistas.

Verificou-se também que a utilização de pisos permeáveis, por exemplo, podem contribuir de forma significativa para a redução dos volumes escoados e das dimensões dos reservatórios, sendo mais facilmente aceitos pelos moradores e naturalmente incorporados ao ambiente criado. BERNARDES da UnB, apud FIORAVANTI (2004), informa que "transformar em gramado um terço de uma área cimentada - uma simples calçada em um lote ou uma parte da área urbanizada da

\footnotetext{
${ }^{140}$ A PMSP, por exemplo, enfatiza que é necessário prever condições de acesso aos reservatórios para que se possa garantir sua manutenção e facilitar os trabalhos de remoção de detritos e limpeza, em particular nos casos de obras subterrâneas que envolvem maiores dificuldades (PMSP/FCTH, 1999).
} 
cidade - permite reduzir em um quarto a vazão de água que haveria se toda a área permanecesse impermeável".

Uma conquista da drenagem urbana, que consolida os esforços do mercado na adaptação dos produtos disponíveis para atendimento ao critério de manutenção do volume pré-existente de escoamento superficial, é o barateamento dos pisos de concreto intertravados, que são considerados pisos semi-permeáveis e cujo uso tem se espalhado pelas cidades. Entretanto, ainda há uma reduzida oferta de materiais que possa substituir o concreto e o pavimento asfáltico, quanto às suas características e preço.

Nos Estados Unidos por exemplo, há alguns anos atrás existiam somente poucas opções de pavimentos permeáveis disponíveis e hoje, o consumidor pode escolher um grande número de materiais inovadores, e sua maior utilização, juntamente com a aceitação da "tecnologia" conduziram a custos cada vez mais atrativos (LID-Center, site). Similarmente, o mesmo pode ocorrer dentro do cenário brasileiro.

SICKERMANN (2001) salienta que os avanços conseguidos "precisam ser respaldados pela iniciativa privada, através de produtos e sistemas que permitam passar em maior escala da teoria para a prática conservacionista. Para responder a este desafio, a indústria e o comércio podem e devem lançar mão da sua capacidade de reagir com flexibilidade a uma demanda detectada".

Segundo SPIRN (1995), oportunidades para prevenção de enchentes existem no projeto de edifícios e parques, no plano diretor metropolitano, nas áreas centrais e na urbanização das periferias, sendo cada nova intervenção na cidade uma nova ocasião para prevenir e mitigar as enchentes ou conservar e recuperar os recursos hídricos e por esta razão, todo projeto deve:

- Tratar da relação entre o local do projeto e os problemas críticos da cidade, bem como dos riscos específicos e recursos que existem na área ou nas redondezas;

- Localizar e projetar edificações e jardins que evitem os danos das enchentes;

- Explorar a capacidade dos telhados, das praças, dos estacionamentos e do solo para reter ou absorver o escoamento; 
- Projetar parques nas várzeas capazes de estocar as águas e resistir aos danos das enchentes;

- Projetar o tamanho, a profundidade, a forma e o horizonte dos corpos d'água urbanos, de modo a melhorar a circulação da água e armazenar as águas pluviais;

- Utilizar a água das grandes chuvas, desde que não estejam contaminadas demais, para atender atividades que não requeiram água potável;

- Explorar as propriedades estéticas da água, sem desperdiçá-las.

\subsubsection{Operação, inspeção e manutenção}

Operação, inspeção e manutenção são atividades importantes para o funcionamento adequado de qualquer sistema de drenagem, porém são fundamentais para os reservatórios de detenção, uma vez que são compostos por estruturas de fácil obstrução.

A PMSP por exemplo, considera que os principais problemas das obras de detenção são aqueles decorrentes da deposição de sedimentos e detritos, que podem desencadear uma série de dificuldades, como a perda da capacidade de armazenamento, geração de odores, problemas de saúde pública, colmatação do sistema, etc. (PMSP/FCTH, 1999).

Para estes itens, devem ser avaliados não somente os custos inerentes a cada uma destas atividades, como também os responsáveis por elas.

Operar um sistema significa colocar em funcionamento os dispositivos existentes, de acordo com os parâmetros determinados nos projetos. Essa operação, que pode ser manual, como no caso do Conjunto Habitacional Jaraguá $\mathrm{H}$ ou automatizada, com ou sem utilização de componentes elétricos, como no Conjunto Habitacional Itaquera C, é de fundamental importância para que os reservatórios alcancem os objetivos desejados e pode ser a chave de seu sucesso ou de seu mau funcionamento.

A inspeção é a mais rotineira das atividade e tem por finalidade detectar problemas gerais nas estruturas, nos dispositivos de entrada e saída, nos extravasores, 
etc. É a atividade que precede a manutenção e é responsável pela conservação das condições de operacionalidade dos reservatórios. A inspeção deve também observar se não há empoçamentos que possam gerar a proliferação de insetos ou o acúmulo excessivo de sedimentos e é recomendável que além da periodicidade normal, seja executada sempre após eventos chuvosos, mesmo que o reservatório não tenha entrado em operação. Além disso, essa atividade pode detectar utilização incorreta do dispositivo e problemas na bacia de contribuição, como por exemplo, ligações clandestinas de esgoto.

A manutenção de um reservatório de detenção consiste, basicamente, na limpeza e retirada de materiais acumulados em seu interior e nos seus distintos componentes, garantindo condições de higiene, segurança e operacionalidade. Ela pode ser periódica, quando atende às recomendações de projetos, ou requerida após inspeções, e realizada sempre que se fizer necessária. No caso de reservatórios com usos múltiplos, os cuidados devem ser redobrados e outras precauções incluídas.

O trabalho de OYAKAWA (2002), por exemplo, aponta dificuldades nas tarefas de manutenção criadas por restrições construtivas (acesso ao gradeamento e piso do reservatório) e observa que o espaço não está sendo utilizado para fins de recreação por falta de "condições de executar uma manutenção adequada".

MARIN et al (1999) constataram que por vezes, a conservação do sistema é ignorada ou considerada de menor importância, gerando manutenções com periodicidade insuficiente ou inadequadas, quando executada.

O CBH-AT considera necessário introduzir a operação e manutenção dos piscinões como assunto prioritário na elaboração dos planos diretores, sob pena das solução propostas monstrarem-se progressivamente ineficazes e inviabilizar o alcance de objetivos propostos.

Como cada sistema de armazenamento é um sistema único, a formulação de manuais de operação e manutenção, que levem em conta as características da bacia hidrográfica, da população e dos responsáveis por sua conservação, é outra etapa muito importante a ser considerada na elaboração dos projetos.

A periodicidade de execução de cada uma das atividades, deve ser contemplada nesses manuais e seus responsáveis devidamente identificados e instruídos. 
CRUZ e AGRA (2003) consideram que os custos de implantação e manutenção dos sistemas de drenagem são problemas a serem equacionados e, apesar de vários autores citarem a transferência da responsabilidade sobre o controle da drenagem para o proprietário como uma vantagem por desonerar o poder público, este comportamento pode gerar obrigações financeiras diretas muito pesadas para a população.

Os estudos de casos apresentados comprovam a teoria acima e demonstram a dificuldade e a inaptidão dos proprietários na operação e manutenção dos sistemas.

Porém quando estas tarefas são encargos públicos, a situação também não é muito diferente, existindo restrições orçamentárias ${ }^{141}$ e de equipamentos para manutenção, somada a coordenação e comunicação deficientes entre as diversas esferas responsáveis pelos diferentes componentes de um sistema de drenagem urbana (PARKINSON, site).

A tabela 44, elaborada pelo DAEE (2000), apresenta uma avaliação feita com dados de 4 reservatórios de detenção implantados na RMSP, e ilustram a situação existente.

Pesquisa divulgada pelo IBGE (2002) sobre municípios com sistemas de drenagem urbana e a realização de manutenção, reforçam a precariedade desta atividade a nível nacional (tabela 45).

Desta forma, a inspeção, a operação e a manutenção dos sistemas de drenagem, em particular dos reservatórios de detenção, continuam sendo assuntos essenciais a serem discutidos com maior intensidade e determinação.

\footnotetext{
${ }^{141}$ Para o reservatório de detenção AM-3 implantado no município de Santo André, foi estimado um custo anual de $R \$ 230.000,00$, somente para operações de limpeza, o que correspondente a $R \$$ $5.476,20 / \mathrm{km}^{2}$ da área da bacia contribuinte (OYAKAWA, 2002).
} 
Tabela 44 - Avaliação da manutenção, monitoramento e vigilância dos reservatórios

\begin{tabular}{|c|c|}
\hline Serviço & Avaliação \\
\hline Vigilância dos reservatórios & Aceitável \\
\hline Limpeza & Ruim \\
\hline Manutenção preventiva & Ruim \\
\hline Manutenção corretiva & Ruim \\
\hline Tratativas entre DAEE e prefeituras & Aceitável \\
\hline Equipamentos para conservação, limpeza e remoção do lixo & Ruim \\
\hline $\begin{array}{l}\text { Proposição de ações para equacionamento dos problemas } \\
\text { existentes }\end{array}$ & Aceitável \\
\hline Desinfecção e higienização & Ruim \\
\hline Preservação das faixas não edificantes & Ruim \\
\hline Cumprimento do Termo de Acordo para Manutenção & Aceitável \\
\hline
\end{tabular}

(Fonte: DAEE, 2000)

Tabela 45 - Municípios com sistemas de drenagem e tipo de atividade de manutenção

\begin{tabular}{|c|c|c|c|c|c|c|}
\hline Região & Brasil & Norte & Nordeste & Sudeste & Sul & $\begin{array}{c}\text { Centro- } \\
\text { Oeste }\end{array}$ \\
\hline Total de municípios & 5507 & 449 & 1787 & 1666 & 1159 & 446 \\
\hline $\begin{array}{l}\text { Possuem sistema de } \\
\text { drenagem }\end{array}$ & 3856 & 196 & 1088 & 1311 & 976 & 285 \\
\hline $\begin{array}{l}\text { Limpeza e obstrução } \\
\text { de dispositivos de } \\
\text { captação }\end{array}$ & 2472 & 104 & 434 & 981 & 754 & 199 \\
\hline $\begin{array}{lr}\text { Limpeza } & \mathrm{e} \\
\text { desobstrução } & \text { de } \\
\text { galerias } & \end{array}$ & 2200 & 79 & 554 & 831 & 549 & 187 \\
\hline $\begin{array}{l}\text { Dragagem e limpeza } \\
\text { de canais }\end{array}$ & 1291 & 43 & 281 & 490 & 357 & 120 \\
\hline Varrição e limpeza & 3341 & 180 & 958 & 1124 & 830 & 249 \\
\hline
\end{tabular}

(Fonte: IBGE, 2002) 


\subsubsection{Segurança}

A implantação de reservatórios de detenção pode trazer riscos para a sociedade e para o meio ambiente. Genericamente, o sistema deve proporcionar segurança para as pessoas e demais seres vivos e proteção para as propriedades e ecossistemas (WANIELISTA, 1990).

Como a água armazenada provém da lavagem das superfícies pelo escoamento excedente, essa água não é potável e transporta consigo, principalmente no início das chuvas, poluentes provenientes da poluição difusa.

Para que não haja riscos à saúde, os resíduos acumulados devem ser retirados e todo o sistema deve ser limpo e, se necessário, desinfetado. No caso de uso integrado como área de recreação, pode-se prever também, um certo intervalo de tempo para a reutilização do espaço, aproveitando o poder de desinfecção dos raios solares.

Especial atenção deve ser dada quanto ao tipo de rede utilizada para esgotamento sanitário local e, no caso de utilização de redes coletoras separadoras, é preciso estar atento às ligações clandestinas de esgoto, fato comum e corriqueiro na maioria das cidades brasileiras ${ }^{142}$.

Quando os reservatórios constituem-se em estruturas enterradas e abertas, deve-se redobrar os cuidados e evitar também quedas de transeuntes através de transições suaves e/ou cercamento.

Neste caso, perante a carência de áreas verdes e de recreação, principalmente nas áreas urbanas mais populosas e de concentração de população de baixa renda, os reservatórios de detenção estão propensos a serem utilizados como piscinas e terem seus dispositivos de saída propositalmente obstruídos. É comum, após os eventos chuvosos, ver crianças brincando em pontos de acúmulo de água (figura 78). Se pequenas poças já são atrações suficientes, os reservatórios de detenção são extremamente tentadores e merecem o devido cuidado.

\footnotetext{
${ }^{142}$ Pesquisa realizada pelo IBGE (2002) demonstra que 81,8\% dos municípios utilizam redes coletoras separadoras, indiferente do porte populacional ou da região geográfica em que estão situados, porém constata-se a existência de redes mistas em todas as regiões, com percentuais variando de 46,9\%
} 


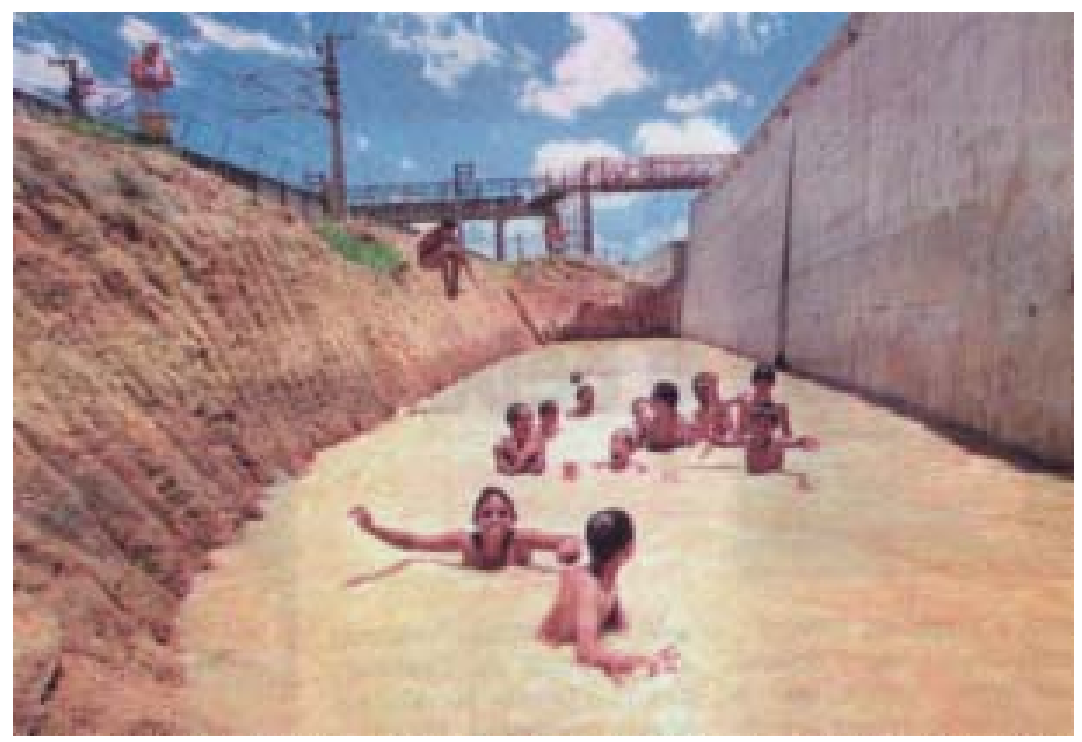

Figura 78 - Utilização indevida de ponto de acúmulo de águas pluviais Fonte: FI Ventura, R. (2004)

NASCIMENTO, ELLIS e DEUTSCH (1999) analisando reservatórios com lâmina de água permanente no Brasil, confirmam que nadar é uma das práticas ilícitas mais populares e difundidas entre os usos feitos pela comunidade local e que essa atividade leva a riscos de afogamentos e contaminações. Acrescentam ainda que devido ao clima quente e úmido, associado à falta de lazer público, torna-se essa atividade ilícita inevitável, mesmo havendo proibição explícita para tal prática.

Para minimizar e até mesmo mitigar o uso indevido dos reservatórios de detenção, deve ser realizado um trabalho de esclarecimento e conscientização da população, primeiramente para esclarecer que a água da chuva não é uma água limpa e, posteriormente, para elucidar o funcionamento do dispositivo de armazenamento e seus objetivos. Tratando-se de áreas públicas, nos casos mais difíceis, pode-se prever também, a contratação de pessoal para orientação das atividades e/ou vigilância do sistema, garantindo os recursos necessários.

Deve-se também investir na sinalização das áreas para que pessoas estranhas ao local possam ser devidamente advertidas quanto à utilização do espaço. 
NASCIMENTO, ELLIS e DEUTSCH (1999) lembram que os gerenciadores dos reservatórios são responsáveis pelos usos ilícitos do sistema, mesmo que involuntariamente.

\subsubsection{Integração de profissionais}

A multiplicidade de disciplinas envolvidas na gestão de recursos hídricos, impossibilita o domínio do rol de conhecimentos necessários por um único profissional, tornando imprescindível o trabalho conjunto e a consulta a especialistas quando necessário.

A elaboração de um bom projeto é decorrente do trabalho conjunto de diferentes profissionais, fundamentada na formação e integração de equipes multidisciplinares, com enfoque na criação de espaços urbanos ambientalmente apropriados e sustentáveis, onde o ambiente correto de trabalho é alcançado pelo diálogo, cooperação e respeito mútuo.

Essa integração de profissionais não se limita aos funcionários de uma única empresa e deve ocorrer também com e entre órgãos e instituições correlatas ao assunto, para que o intercâmbio de conhecimentos, domínios e especialidades seja concreto e eficiente.

TUCCI (1997) observa porém, que grupos interdisciplinares apresentam problemas de inter-relacionamento de profissionais com conhecimentos distintos e que, para superação dessas dificuldades, há a necessidade de conhecimentos básicos em diversas outras disciplinas, que não aquela de domínio por parte de cada um dos componentes dos grupos.

BINDER (1998) considera como pré-requisito para a utilização de soluções alternativas a conscientização dos engenheiros a respeito dos problema e soluções ambientais, bem como, a formação de equipes que trabalhem interdisciplinarmente.

Atualmente, muito se tem falado sobre trabalhos em equipe e trabalhos multidisciplinares e a drenagem urbana, assim como questões ambientais, são excelentes vetores de desencadeamento desses processos. 
No caso dos reservatórios de detenção em particular, é impossível o desenvolvimento unilateral do projeto, pois este será na maioria das vezes inadequado, sujeito a todo tipo de críticas e poderá inclusive não ser implantado.

\subsubsection{Formação e capacitação do corpo técnico}

A engenharia hidráulica é extremamente dinâmica e requer constante atualização e especialização dos profissionais que nela atuam. A drenagem urbana em particular, provavelmente pelo reduzido número de obras de grandes vultos ou por contar com serviços esporádicos, tem uma quantidade limitada de profissionais, da qual uma grande parcela está locada em órgãos governamentais (prefeituras, companhias de água e esgoto, órgãos ambientais, instituições de ensino, etc.).

Hoje, observa-se que há uma carência de profissionais aptos a desenvolverem projetos de drenagem urbana no mercado, seja pela inexperiência ou pela falta de atualização.

A própria mudança de conceitos que envolve a drenagem urbana nos últimos anos leva à necessidade de se repensar a formação acadêmica, não só dos engenheiros propriamente ditos, como também e principalmente dos urbanistas, responsáveis pelo desenho urbano, e dos administradores, responsáveis pelo planejamento das cidades.

URBONAS (1999) ressalta que os projetistas e planejadores devem refletir sobre a melhor maneira de gerenciar o escoamento superficial para limitar os prejuízos causados às propriedades a jusante, reduzir a erosão nos cursos d'água, limitar os efeitos sobre a flora e a fauna dos corpos receptores e integrar as soluções de drenagem à comunidade, porém reconhece a dificuldade dos profissionais em identificar medidas mais sustentáveis e correlacioná-las quantitativamente com os processos de escoamento superficial urbano e com os vários efeitos decorrentes sobre os corpos receptores.

TUCCI e MARQUES (2000) observam que "os projetos de drenagem urbana foram ensinados aos engenheiros e ainda muitos são desenvolvidos com a filosofia de que a melhor drenagem é a que expulsa a água do local o mais rápido possível”, 
denotando necessidade de atualização profissional e de "forte atualização sobre o assunto" por parte das instituições de ensino.

Concomitantemente, os autores salientam que a população está menos preparada ainda para aceitar os novos princípios da drenagem urbana e segue acreditando em construções de canais e condutos como solução para os problemas urbanos, sem perceber "que na maioria das vezes este dinheiro está sendo gasto para agravar a situação das cidades".

GRACIOSA (2004) comenta que de fato, até pouco tempo atrás, a bibliografia existente no Brasil sobre drenagem urbana consistia quase que exclusivamente, em obras sobre o sistema clássico de rápido afastamento das águas pluviais de sua origem.

ANDOH (1994), apesar de considerar que os engenheiros têm sido treinados para utilizar conceitos tradicionais, acrescenta que os arranjos institucionais, na maioria dos países, não favorecem a implementação de conceitos alternativos.

BINDER (1998) esclarece que a incorporação de aspectos ambientais pela conscientização dos engenheiros hidráulicos na Europa foi um processo bastante demorado, mas que hoje a engenharia ambiental já faz parte do currículo de formação profissional de engenheiros ligados a recursos hídricos.

PARKINSON (site) observa que há notoriamente resistência ao uso de "padrões naturais de drenagem" e que freqüentemente os projetos não respeitam o curso natural das águas e as áreas alagadiças. Porém, AGRA e CRUZ (2003) ressaltam que "novos paradigmas relacionados com a valorização da água no meio urbano orientam a atuação dos planejadores dos sistemas de drenagem urbana a adotarem novos princípios e posturas, no sentido do abandono das técnicas convencionais, muitas vezes consideradas retrógradas".

Muitas soluções para a drenagem urbana são pensadas nas universidade e instituições de ensino, mas há uma distância muito grande entre pesquisa, divulgação e implementação. Existe claramente um problema de transferência de tecnologia do conhecimento à prática e é um desafio à popularização desta e à sensibilização do meio técnico no tocante à drenagem (PARKINSON et al, 2003).

Os estudos de casos apresentados provaram que tratando-se de reservatórios de detenção, todas as críticas acima são verdadeiras e demonstraram o despreparo 
dos profissionais, a resistência na incorporação destes elementos, a carência de diálogo entre instituições, além da necessidade de atualização profissional e de amadurecimento das questões anteriormente encaminhadas.

\subsection{Impactos Econômicos}

Do ponto de vista econômico, os reservatórios de detenção devem propiciar o menor investimento e custos anuais compatíveis com as exigências e restrições de seus responsáveis (WANIELISTA, 1990).

Existem dois tipos de custos que devem ser considerados com relação aos impactos econômicos da implantação de um reservatório de detenção: os custos da implantação do reservatório propriamente dito e os custos de operação e manutenção do sistema.

Ambos possuem uma incidência temporal e quantitativa particular, resultando em diferentes implicações.

\subsubsection{Implantação dos reservatórios}

O custo de implantação dos reservatórios não é reincidente e seu impacto é inicial, nas fases de projetos e obras.

Esse custo está diretamente relacionado com as características do empreendimento e seu valor é extremamente variável, pois um reservatório enterrado, coberto e em concreto será mais caro do que um reservatório enterrado, aberto e em concreto, que por sua vez será mais caro aberto em terra, apesar de cumprirem a mesma função.

Neste caso é necessário avaliar somente as alternativas apropriadas às características locais e aos resultados esperados. A comparação generalizada dos custos de implantação dos reservatórios pode levar a erros grosseiros e ser pouco significativa. O melhor a ser feito para obter um parâmetro de comparação para pequenos reservatórios é agrupá-los por tipo de material do corpo de 
armazenamento, estrutura de saída utilizada e volume armazenado, que são os itens de maior variação e custo. Porém, toda comparação requer cuidados e verificação da similaridade das estruturas propostas.

O aproveitamento de condições naturais favoráveis ajudam a reduzir custos, assim como a utilização simultânea de outras soluções alternativas.

De forma geral, os custos de implantação dos reservatórios de detenção, nos estudos de casos apresentados, são pequenos se comparados com o custo total do empreendimento e giram em torno de $2 \%$, porém ainda representam um gasto adicional, a ser devidamente justificado.

\subsubsection{Inspeção, operação e manutenção}

Inspeção, operação e manutenção são elementos imprescindíveis e seus custos se perpetuam ao longo do tempo de utilização dos reservatórios de detenção, sendo diretamente relacionados com o tipo de reservatório implantado e as condições existentes a montante: outros sistemas de drenagem, uso e ocupação do solo, declividade do terreno, tipo de cobertura, produção de resíduos, tipo de redes coletoras de esgoto existentes, etc.

A periodicidade destas atividades deve estar prevista nos manuais de operação e manutenção, e seus custos variam dependendo das estações do ano.

De qualquer forma é necessário garantir recursos e identificar os responsáveis por essas atividades, caso contrário haverá o abandono da estrutura e a criação de situações desfavoráveis.

Os empreendimentos estudados neste trabalho, apontam o desconhecimento e a restrição econômica da população como entraves a essas atividades, e apontam a necessidade de serem extremamente simples e sem equipamentos elétricos.

Além disso, a simples manutenção do próprio empreendimento, principalmente dos dispositivos de drenagem adjacentes, é essencial e reflete na periodicidade das manutenções dos reservatórios de detenção. 
Para a população de baixa renda, taxas ou incentivos fiscais destinados a conservação dos sistemas de drenagem são medidas de pouco alcance mesmo que venham a ser adotadas pela legislação ${ }^{143}$.

Em particular no município de São Paulo, onde a implantação de reservatórios em conjuntos habitacionais de interesse social é dificultada pelas imposições da legislação e podem gerar custos elevados para os padrões de seus moradores, a CDHU vem procurando soluções alternativas de armazenamento que possam significar manutenções mais esporádicas e custos reduzidos, pois não há como impor a realização destas atividades e a experiência com estruturas convencionais de reservatórios não tem sido positiva.

\subsection{Impactos Sociais}

Soluções contra as enchentes exigem uma revisão do papel dos moradores das cidades. Segundo afirma ROSS, da USP, “os proprietários dos espaços públicos e privados - e não só os novos empreendedores - devem ajudar a reter as águas pluviais" (FIORAVANTI, 2004).

A redução dos impactos sociais decorrentes da implantação de sistemas de drenagem, em particular dos reservatórios de detenção, por constituirem-se em dispositivos novos e de recente difusão, deve ser alcançada pela sensibilização, conscientização e educação da sociedade em todos os níveis, de forma que sua implementação e manutenção sejam impulsionados pela própria população, assim como já acontece nos países mais desenvolvidos, e para que possa haver uma constante valorização através da integração de usos.

"Nota-se que os impactos de características não-hidrológicas na drenagem urbana se originam, em sua totalidade, nos problemas sociais brasileiros, conseqüência dos interesses políticos locais e, em última instância, da estrutura organizacional macro-econômica do país" (Neto, 2004).

${ }^{143}$ Ver capítulo 7, item 7.1.3. 


\subsubsection{Sensibilização e conscientização}

Os sistemas de drenagem ou a falta deles só são percebidos pelo seu mau funcionamento ou na ocorrência de eventos extraordinários de chuvas, que provocam transtornos e prejuízos às cidades. Na maior parte do tempo, passam esquecidos e desvalorizados, muitas vezes servindo de depósito de lixo. As próprias prefeituras relegam os sistemas de drenagem a um segundo plano, não executando inspeções periódicas e manutenções preventivas das estruturas existentes ou simplesmente abandonando-os.

ANDOH (1994) comenta que infelizmente, a falta de políticas de planejamento e controle, junto com a falta de consciência da importância dos caminhos naturais da drenagem, têm resultado em intervenções que desrespeitam e obstruem esses sistemas.

TASSI (2002) confirma que, na maioria das vezes, a sociedade ignora a verdadeira causa dos problemas de drenagem e atribui a responsabilidade dos acontecimentos às decisões políticas, porém a ausência de planos de uso e ocupação do solo e a inexistência de fiscalização corroboram para o agravamento da situação.

A percepção da importância da drenagem para a sociedade em geral, ainda é muito baixa quando comparada com a dos sistemas de água e esgoto, por exemplo. Poder-se-ia dizer que a maioria desconhece para que servem e como funcionam os sistemas de drenagem, e é bastante comum, encontrar pessoas utilizando sarjetas, bocas de lobo e cursos d'água como depósitos de lixo ${ }^{144}$ : Existe a consciência de que a "água leva", mas não há a consciência de que a obstrução dos sistemas de drenagem "traz a água de volta".

Os principais fatores que influem na existência de resíduos sólidos nos sistemas de drenagem em áreas urbanizadas consolidadas são (TUCCI e MARQUES, 2001):

- Freqüência e cobertura da coleta de lixo;

- Freqüência da limpeza das ruas;

- Forma de disposição do lixo pela população;

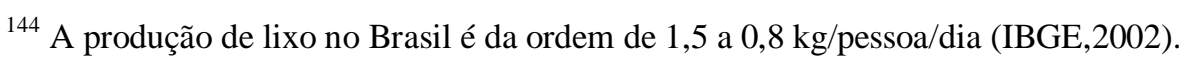


- Freqüência da precipitação;

- Valor econômico do resíduo.

TUCCI e MARQUES (2001) apontam que no Brasil não existem informações sobre a quantidade de lixo retido pelos sistemas de drenagem e, mesmo a nível internacional, estas informações são reduzidas. LAGER et al (1977), citados pelos organizadores acima, fornecem para San Jose, Califórnia, um valor estimado de 4 $\mathrm{lb} /$ pessoa/ano nos sistemas de drenagem e $1,8 \mathrm{lb} /$ pessoa/ano $^{145}$ em condutos e ruas. Segundo o site da ABES - SP, "estudos indicam que da totalidade do material que polui os mananciais do estado de São Paulo, entre $20 \%$ a $30 \%$ são relativos aos lançamentos e resíduos provenientes dos depósitos irregulares de lixo, carreados pela água da chuva".

Para Ajayi (1993) citado por ANDOH (1994), na maioria dos países em desenvolvimento, a disposição dos resíduos sólidos está intimamente ligada ao sistema de drenagem urbano, onde os canais de drenagem terminam sendo receptáculos dos resíduos gerados pela comunidade.

A má qualidade da limpeza urbana e a falta de conscientização da população trazem grandes prejuízos à qualidade da água pluvial escoada para os cursos d'água e o excesso de lixo é um empecilho para a implantação de reservatórios, além de aumentar os riscos sanitários e o custo de manutenção dos sistemas de drenagem (Parkinson et al, 2003)

A quantidade de lixo produzido e disposto, correta ou incorretamente, no meio ambiente é resultado direto dos padrões e formas de consumo, além da capacidade de reaproveitamento e reciclagem desses materiais, podendo haver grandes variações de um local para outro.

Pode-se concluir que não basta ter área, dispor de aterros sanitários ou incineradores, se não houver conscientização da população e estímulos para diminuir drasticamente, a utilização dos cursos d'água como receptores e transportadores de lixo.

${ }_{145} 1,82 \mathrm{~kg} /$ pessoa/ano e $0,8 \mathrm{~kg} /$ pessoa/dia, respectivamente. 
Para a PMSP é importante saber o grau de educação da população das bacias contribuintes, uma vez que este aspecto tem uma relação muito estreita com o lixo lançado diretamente no sistema de drenagem, e também atentar para os grandes produtores de resíduos, como as feiras-livres.

No caso dos reservatórios de detenção implantados em lotes ou loteamentos para a população de baixa renda, a sensibilização e conscientização é ainda mais difícil, pois na maioria dos casos os níveis cultural, de informação e de comprometimento são baixos e os benefícios indiretos, apesar dos custos serem diretos, agravando a situação restritiva em que vivem.

Consultas prévias à sociedade para verificação da sua aceitação e participação contínua, durante todo o processo de implantação dos reservatórios de detenção, são boas práticas que estimulam o engajamento com os objetivos propostos, pois a população se sente mais respeitada, tem suas opiniões valorizadas e participam como co-autora dos projetos.

A comunidade precisa estar sensibilizada e conscientizada para entender a importância e a finalidade dos reservatórios de detenção e conviver pacificamente com esses dispositivos. É necessário aprofundar e trabalhar também, o conceito de valor comunitário e de respeito com o meio ambiente e com o próximo, pois há a questão da distribuição irregular de benefícios.

A CETESB (1986) ressalta a importância dos benefícios indiretos, proporcionados por sistemas de drenagem bem projetados, pela forma ordenada como as áreas urbanas se desenvolvem, sem interferências de inundações e de prejuízos ao tráfego de veículos e de pedestres. Tanto a CETESB (1986) quanto PORTO (2004) enumeram alguns deles:

- Redução de prejuízos decorrentes das inundações;

- Redução do custo de manutenção das ruas;

- Redução de paralisações de serviços e atividades econômicas;

- Melhoria do tráfego de veículos durante as chuvas;

- Benefícios à saúde e à segurança públicas;

- Maiores oportunidades de implantação de parques e áreas de recreação e lazer; 
- Recuperação de terras inaproveitadas;

- Melhor proteção das margens e menos assoreamentos;

- Controle do lençol freático e saneamento das baixadas.

Em Porto Alegre por exemplo, moradores de um bairro recusavam-se a aceitar a transformação de algumas praças em reservatórios porque em primeiro lugar, temiam que o local se transformasse em depósito de lixo e também porque não eram diretamente atingidos pelas enchentes, problemas estes somente dos bairros vizinhos situados em terrenos mais baixos (FIORAVANTE, 2004).

Em outro caso, em Recife, a comunidade diretamente beneficiada não só aceitou participar da busca de soluções para os constantes alagamentos da área, como também colaborar na manutenção do sistema, "de modo que ficou acordado que a própria comunidade faria a limpeza das grelhas de entrada para evitar acúmulo de materiais sólidos" (MELO et al., 2001).

NASCIMENTO, ELLIS e DEUTSCH (1999) observam que a interação da população local com este tipo de dispositivo varia muito, dependendo do contexto urbano, indo da rejeição à aceitação, e que este último caso está normalmente relacionado com reservatórios que oferecem usos múltiplos.

Segundo SÁNCHES (2001), a divulgação e a educação são formas diretas de alcançar estes objetivos, seja através dos meios de comunicação em massa, ONGs ou demais entidades organizadas.

O processo de sensibilização e conscientização da população também sofreria grande impulso se os órgãos governamentais em seus vários níveis, adotassem medidas de armazenamento de águas pluviais em todos os novos projetos e propiciassem a adequação dos equipamentos e edifícios públicos para essa nova finalidade, divulgando e incentivando a população a seguir seus exemplos.

O que se presencia até o momento, é apenas a construção de grandes reservatórios de detenção compreendidos pela população como uma obra qualquer de galerias ou retificações de canais, funções estas predominantemente do poder público, sem haver porém, ações de menor vulto, mais coerentes com as solicitações feitas aos proprietários e a sociedade, para que estes possam perceber que há também um esforço do próprio governo na redução e controle do escoamento na fonte. A 
impressão que se tem hoje é a de se cobra da sociedade atitudes que a própria administração pública não adota.

Por outro lado, COSTA e SANTOS (1999) ressaltam que existem ações quanto aos cuidados com a água que exigem a participação de governos, mas a maioria depende de atitudes pessoais, fruto de uma ética de responsabilidade solidária, desenvolvida a partir de uma postura cidadã, pois não cabe mais a postura do usuário espectador. "A nova ordem é o cidadão, ou grupo de cidadãos, buscar alternativas para resolver os problemas da água, levando em conta as necessidades e dificuldades vivenciadas pelas próprias comunidades".

A parceria entre governo e comunidades locais no gerenciamento de recursos hídricos, contribui para tornar transparentes as ações e podem promover o sentimento de propriedade/responsabilidade pelos sistemas hídricos. Além disso, a cooperação social é imprescindível para enfrentar problemas cujas natureza ou intensidade são ainda desconhecidas, como é o caso dos cuidados que devem ser tomados com relação ao meio ambiente" (COSTA e SANTOS, 1999) e (MEDEIROS, 1999).

Assim, a sensibilização e a conscientização, propulsoras da participação e da informação da sociedade civil, são consideradas como pré-requisitos para o sucesso no controle do escoamento superficial nas cidades, ajudando na aceitação, implantação e manutenção de novos reservatórios.

\subsubsection{Aproveitamentos múltiplos}

A utilização de reservatórios de detenção para outras finalidades concomitantemente com sua utilização para contenção de cheias, é a melhor forma de preservar sua implantação, agregar valor e facilitar sua aceitação pela sociedade.

Como trata-se de estruturas que são utilizadas ocasionalmente, caso não haja uma integração de usos, pode-se passar a impressão de que é um elemento de pouca importância e que o espaço ocupado pode ser melhor aproveitado ${ }^{146}$.

\footnotetext{
${ }^{146}$ TUCCI e MARQUES (2000) observam que apesar das condições climáticas recentes mostrarem que o impacto das cheias tem sido menor, o fato de não ter havido nenhuma enchente importante que exigisse o funcionamento dos diques e das estações de bombas do sistema de drenagem da região metropolitana de Porto Alegre, gerou na população uma sensação de segurança que levou alguns
} 
Quando as condições financeiras da população são precárias, essa impressão intensifica-se e pode tornar-se mais um fator de incentivo para a ocupação indevida e o uso irregular, assim como acontece com as áreas ribeirinhas de rios e córregos.

A apropriação deste espaço pela população, a integração dos reservatórios de detenção na ambientação paisagística, junto com sua utilização para fins recreacionais são as mais oportunas, importantes e as primeiras das alternativas a serem consideradas, ao mesmo tempo em que são as melhores formas de combater e evitar invasões.

Segundo SPIRN (1995), o armazenamento da águas das cheias e o lazer são atividades compatíveis nos grandes parques urbanos e a recente profusão dessas áreas, que servem a múltiplos usos, não refletem uma nova idéia, mas a redescoberta de velhas soluções ${ }^{147}$.

NASCIMENTO, ELLIS e DEUTSCH (1999) acreditam que apesar de difícil, quando bem integrados na área urbana, os reservatórios de detenção podem também proporcionar a prática de esportes e atividades de lazer, assim como tornar-se um local para relaxamento e desenvolvimento da vida animal, aumentando a qualidade de vida da população.

URBONAS e STAHRE (1993) acrescentam que a implantação de reservatórios de detenção pode ser tão bem sucedida que as funções hidráulicas passam a ser consideradas secundárias pela população.

Muitas vezes, assim como está previsto para o Conjunto Habitacional Herculândia C, a simples ampliação da área de inundação nas margens dos cursos de água é suficiente para criar um volume compatível com as exigências de projeto. Para lotes com apartamentos, a mesma premissa deve ser perseguida, procurando ajustar áreas livres e de recreação com locais para implantação dos reservatórios.

Formas clássicas de reservatórios devem ser evitadas e formas menos comprometedoras e dependentes de manutenção devem ser criadas. Como no presente trabalho não é apresentado nenhum caso de detenção em lotes com essas

urbanistas e ambientalistas a questionar a existência dessas estruturas, tendo sido aprovada uma legislação específica autorizando a prefeitura nesse sentido, pela câmara dos vereadores.

147 Parques do século XIX e do início do século XX, foram originalmente projetados como controladores de enchentes e sistemas de tratamento das águas. Entretanto poucos conhecem essas finalidades, cujas informações se perderam ao longo do tempo, restando aparentemente somente seu uso recreacional. 
características, acrescenta-se algumas ilustrações (figuras 79, 80, 81, 82 e 83) de um conjunto residencial em Denver, no Colorado, onde o armazenamento é feito no recuo frontal, na área destinada a quadras esportivas e nas áreas livres, de forma extremamente natural.

Embasados no discurso ambiental do desenvolvimento sustentável, empreendimentos habitacionais voltados para classes mais altas já tiram proveito de áreas verdes e sistemas de tratamento de esgoto, por exemplo, como elementos de marketing e de agregação de valor. A retenção voluntária em lotes ou loteamentos também pode enquadrar-se nesse molde e necessita ser melhor explorada.

SPIRN (1995) observa que cidades européias como Stuttgart utilizam "tetos molhados" para reduzir o ganho de calor dos edifícios e diminuir o consumo de energia com condicionamento de ar, e quando são incorporados ao projeto como telhados jardins, a retenção de águas pluviais pode também se tornar um elemento estético.

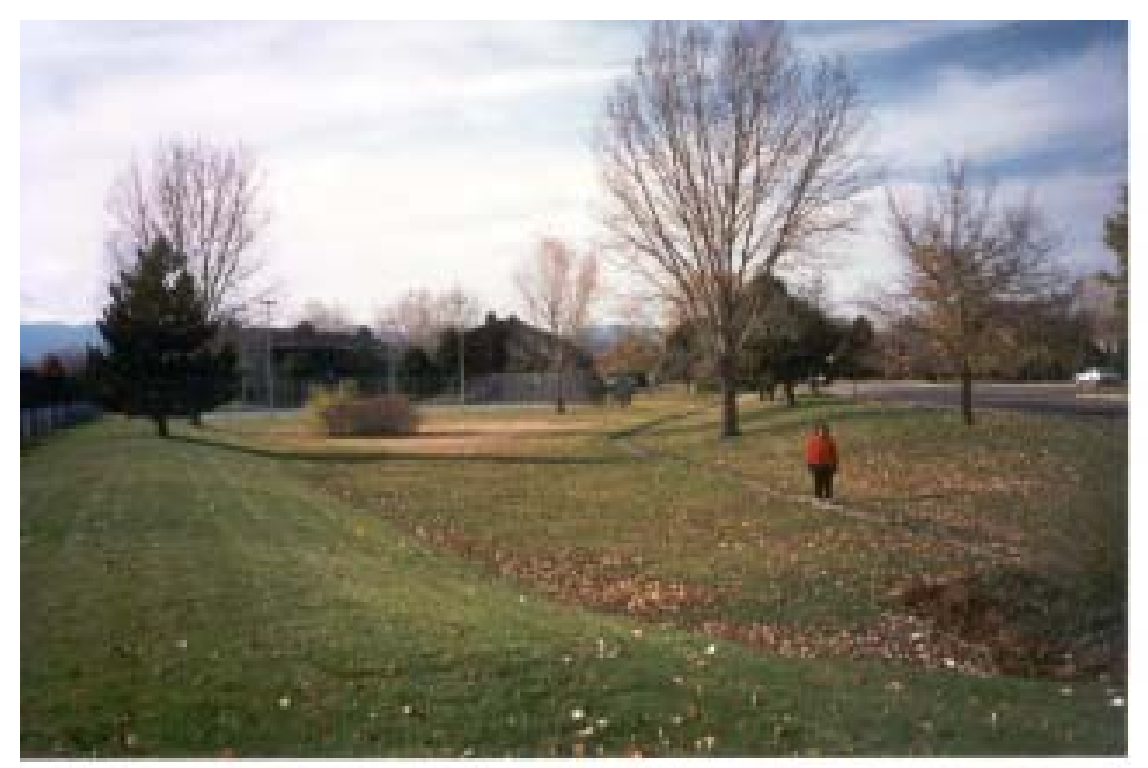

Figura 79 - Reservatório de detenção criado no recuo frontal Fonte: Porto (1983) 


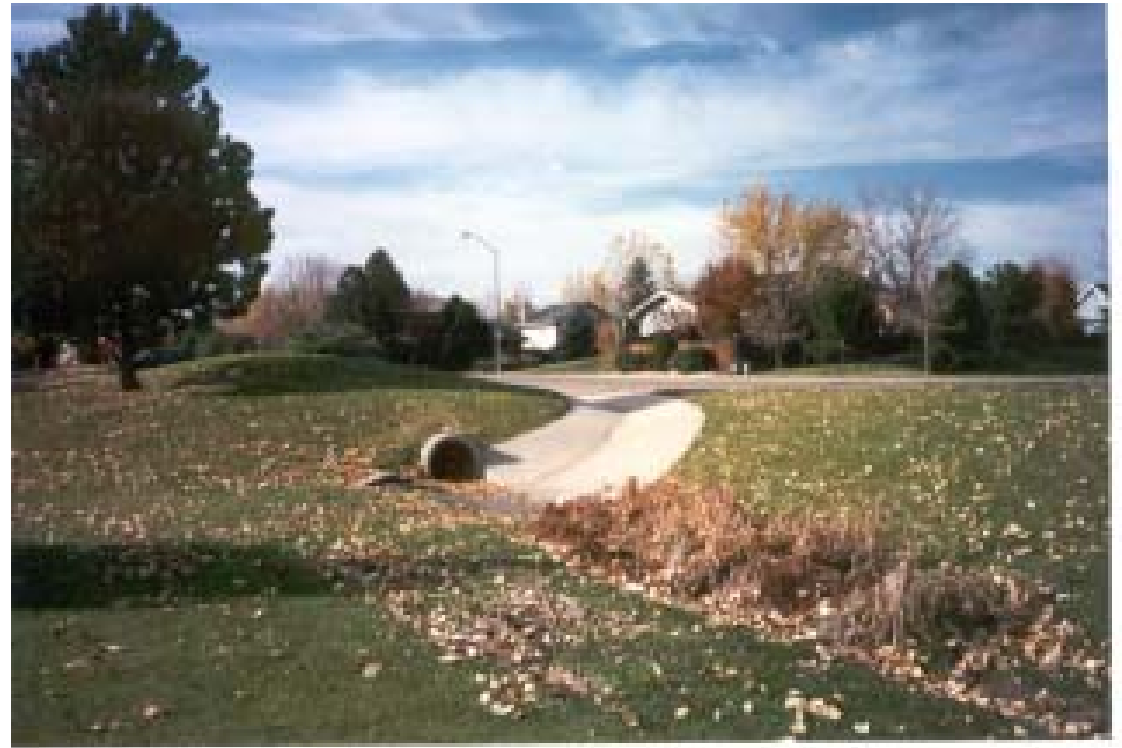

Figura 80 - Reservatório de detenção em recuo frontal e o dispositivo de saída Fonte: Porto (1983)

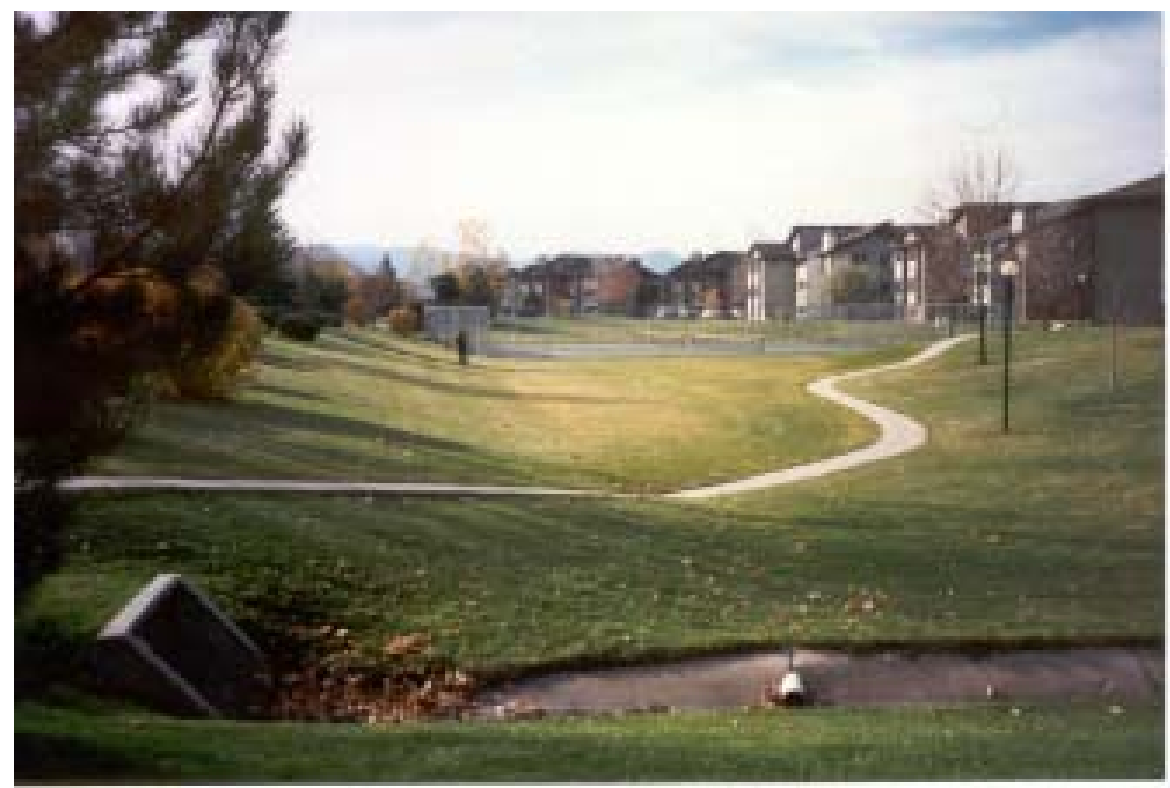

Figura 81 - Reservatório de detenção em área de recreação

Fonte: Porto (1983) 


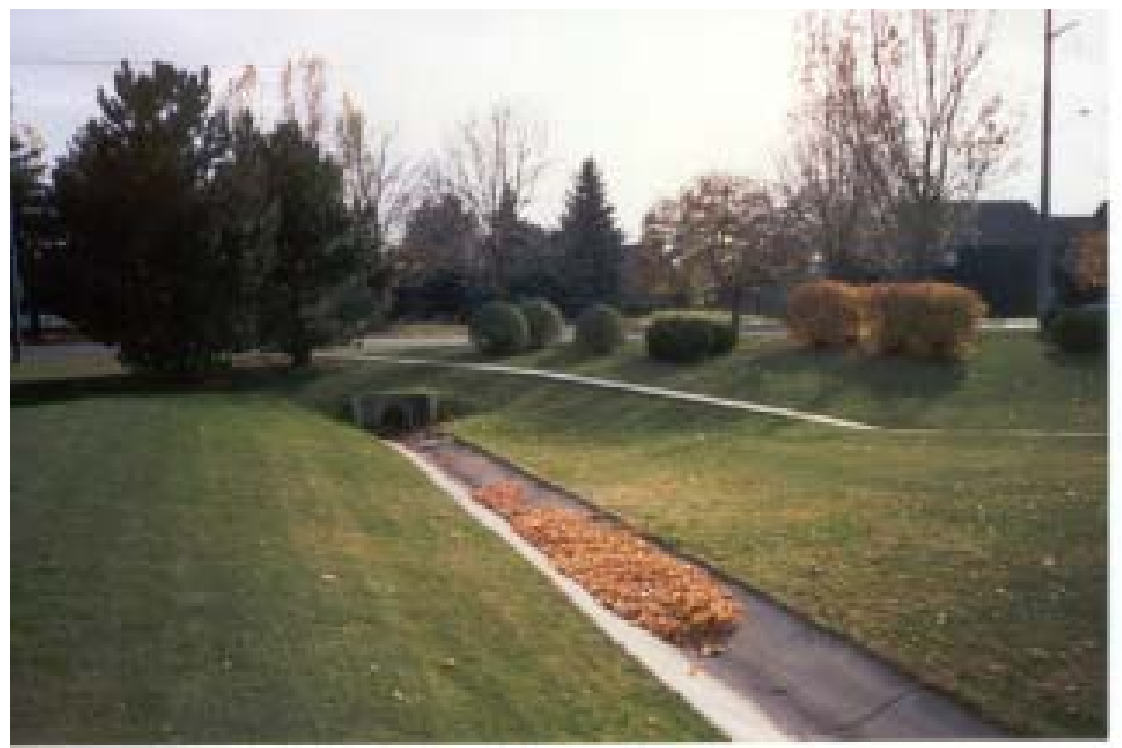

Figura 82 - Espaço livre aproveitado para armazenamento de água Fonte: Porto (1983)

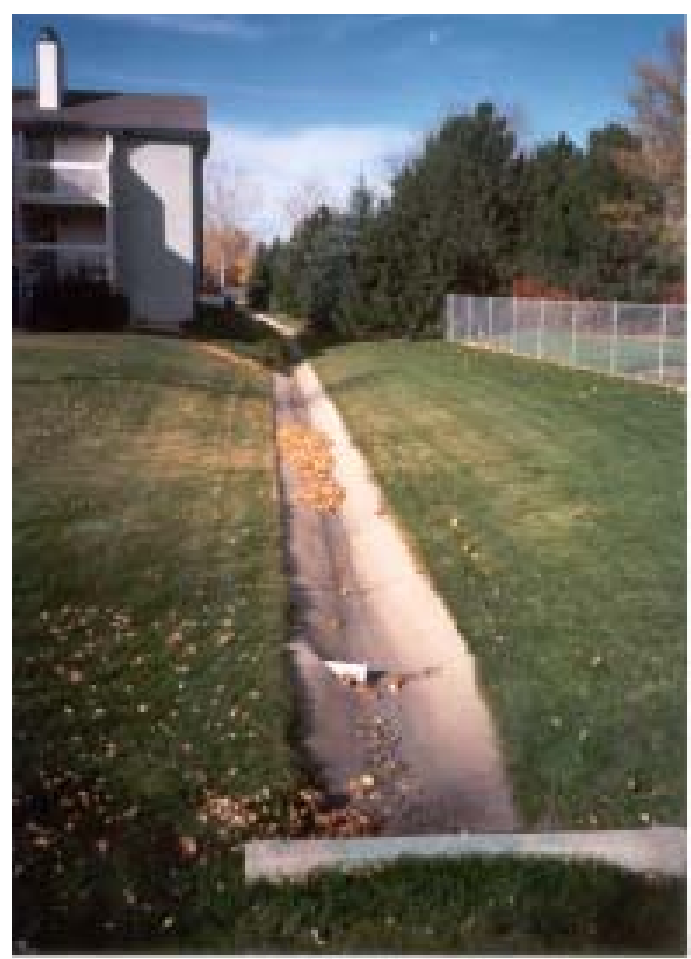

Figura 83 - Armazenamento criado em recuo lateral Fonte: Porto (1983) 
Para TUCCI e MARQUES (2001), faz-se necessária a implementação de campanhas promocionais de incentivos à manutenção de ambientes naturais, mostrando à população a importância da existência de áreas livres permeáveis do ponto de vista ambiental.

A alternativa de utilização de parques e praças como áreas de detenção porém, encontra grande resistência por parte da secretaria municipal do meio ambiente de Porto Alegre, cujo principal argumento contrário é a utilização de sistema de esgoto misto em grande parte da cidade ${ }^{148}$ (TUCCI e MARQUES, 2001). Opostamente, a CETESB (1986) considera a construção de pequenos reservatórios, mesmo no centro de áreas urbanas, como uma possibilidade interessante.

Em especial para a CDHU, onde a prioridade é maximizar o número de unidades habitacionais implantadas e garantir sua segurança ao menor custo possível, áreas destinadas à recreação e todo e qualquer outro objetivo ficam em segundo plano. Entretanto, isso não significa que não haja possibilidade de um trabalho mais acurado durante a concepção dos projetos para alcançar estes objetivos. Significa sim, que na maioria dos casos, as áreas disponíveis são inadequadas para adotar este tipo de solução.

Outro uso possível para os reservatórios de detenção é sua utilização como instrumento de captação de águas pluviais para abastecimento de cisternas de armazenamento de água não potável, destinada à rega de jardins ou lavagens de áreas comuns, tendo como fator limitante a qualidade da água gerada pelo escoamento superficial (ANDOH, 1994) e (PARKINSON et al, 2003).

Uma pesquisa da Universidade da Malásia deixou claro que após o início da chuva, somente as primeiras águas carreiam ácidos, microorganismos e outros poluentes atmosféricos, sendo que normalmente pouco tempo após, a mesma já adquire características de água destilada e pode ser coletada em reservatórios fechados (CETESB, site).

Para este fim seria necessário dispor de área para implantação de um outro reservatório (cisterna), viabilizar suas estruturas, criar formas de operação e manutenção, além da implantação de uma rede auxiliar de água não potável.

${ }^{148}$ TUCCI e MARQUES (2001) comentam que em Porto Alegre, “o arroio, que poderia ser um elemento benéfico do ponto ambiental e paisagístico, inclusive agregando valor às propriedades 
As principais preocupações geradas neste caso, são as ligações cruzadas que podem comprometer a água potável, a qualidade da água de reuso e sua utilização indevida. Relativamente a esta última questão, a utilização de corantes orgânicos pode ser uma solução de baixo custo e de fácil compreensão, mesmo para pessoas com baixo grau de instrução.

PRATT (1999) considera o reuso como uma vantagem adicional perante a escassez de água potável e o aumento dos preços dos serviços de abastecimento. O princípio é que o custo adicional envolvido no desenvolvimento destes sistemas seja, a longo prazo, coberto pela redução no consumo de água potável. Porém é necessário uma análise apurada dos custos envolvidos e de seu retorno, e em particular para a população de baixa renda, coloca-se novamente a questão dos subsídios discutida no capítulo 7, item 7.1.3.

Existe também a possibilidade de utilizar os reservatórios de detenção para melhorar da qualidade da água, mas para que isso seja possível é necessário adotar alguns critérios específicos de dimensionamento. Estudos apontam que pequenas modificações no dimensionamento e no desenvolvimento dos dispositivos de entrada e saída podem contribuir de forma significativa para a melhoria da qualidade dos corpos de água, principalmente com relação a sólidos suspensos (OLIVEIRA, 2004).

Segundo OLIVEIRA (2004), os reservatórios de acumulação "podem e devem não somente desempenhar o papel de amortecer o hidrograma de cheia, mas também o de melhorar a qualidade da água".

De qualquer forma, deve ser considerado o conflito de usos, uma vez que os volumes requeridos para melhorar a qualidade da água são menores do que os necessários para o controle quantitativo do escoamento superficial. Os reservatórios para controle da qualidade da água são usualmente projetados para captar chuvas menores ou somente o escoamento inicial (first flush) das chuvas maiores e além disso, o tempo de residência da água é maior para permitir a sedimentação do material particulado (MOELLER e LIPPER, 2001).

Nos casos estudados, nota-se a expectativa da população em relação aos usos múltiplos dos reservatórios de detenção e também uma inversão de valores, onde outras funções ganham relevância em relação ao controle de cheias urbanas.

vizinhas, tem se transformado em fonte de problemas. 


\subsubsection{Educação ambiental}

Infelizmente o cenário encontrado nos conjuntos da CDHU não é diferente do que se vê por todas as cidades, onde o lixo e sua disposição inadequada ainda são problemas crônicos que prejudicam o desempenho dos reservatórios de detenção.

Experiências têm mostrado que esforços educacionais podem positivamente promover o engajamento público na proteção das águas, pelo simples fato de incentivar a manutenção de suas próprias propriedades e a disposição correta do lixo (LID-Center, site).

Programas de educação ambiental podem ser desenvolvidos em parceria com as prefeituras, organizações não governamentais e diferentes segmentos da sociedade organizada, para serem ministrados em locais públicos, como escolas e ginásios esportivos.

Em especial para os proprietários/usuários dos reservatórios de detenção, devem ser ministradas também noções mais específicas sobre essas estruturas para que estes sejam multiplicadores de conhecimentos e façam uso correto do dispositivo quando há aproveitamentos múltiplos.

PIEL, PEREZ e MAYTRAUD (1999) ressaltam que a mudança na forma de lidar com as águas pluviais nas cidades, sem aumentar os distúrbios associados, significa manter a população informada e tornar os cidadãos conscientes dos impactos da chuva em áreas densamente urbanizadas. Isso estende-se também aos significados técnicos e econômicos de gerenciar este fenômeno de forma segura, com o mínimo de inconvenientes, e a compreensão das limitações de cada sistema.

Desta forma, a reação pública às consequiências de chuvas excepcionais, com tempo de retorno maior do que o adotado nos projetos, será menos crítica e mais objetiva.

MARIN et al (1999) observam que um dos principais obstáculos da educação ambiental, é a incorreta divulgação dos problemas de inundação feita pela imprensa, que rotineiramente considera córregos em área urbana como "agentes de poluição ou destruição, nos eventos críticos de chuva", levando a inadequada percepção do papel dos cursos d'água nas cidades. 
A mídia então, não tem alcançado sua função social na divulgação de práticas sustentáveis de controle de cheias, mostrando somente seus aspectos negativos, principalmente quando ocorrem extravasamentos dos reservatórios, sem divulgar que na inexistência de tais dispositivos haveria a intensificação do problema e o aumento de sua frequiência.

Isso porém não exime os governantes de suas responsabilidades no disciplinamento e fiscalização das atividades urbanas e nem os profissionais da busca de atualização curricular e da elaboração de projetos adequados com os objetivos a que se propõem.

A conservação das áreas permeáveis e a preservação das áreas verdes são dois outros assuntos que devem constar nos programas de educação ambiental, de modo que não se ampliem os volumes de cheias para os quais o sistema de drenagem, particularmente os reservatórios de detenção, foram dimensionados.

Concomitantemente com a educação da população, é necessário implementar serviços correlatos, como coleta regular e seletiva do lixo, para incentivar a prática de bons hábitos e garantir o funcionamento dos dispositivos de drenagem.

O processo de educação ambiental, onde ocorre a conscientização do indivíduo e busca-se mudanças de práticas e atitudes, é mais eficiente se estiver relacionado à realidade específica do dia a dia e for ilustrado com exemplos práticos locais (MARIN et al, 1999).

O Japão, consciente de que todo processo de mudança de hábitos é difícil e vagaroso, concentra seus esforços na educação das crianças, para que através delas se processe essa transformação, investindo primordialmente na formação dos futuros cidadãos (JICA, 1996).

No Brasil, a educação ambiental mais consistente está centralizada nos cursos de graduação e pós-graduação, sub-dividida por temas de acordo com cada especialidade, não atingindo a maioria da população.

Para URBONAS (1999), saber em que grau e em que quantidade mudanças de comportamentos podem ser alcançadas através da educação, ainda são questões a serem respondidas. E para que ela venha a funcionar é necessário um trabalho de sensibilização e convencimento. 
WALESH (1993, 1997) apud URBONAS (1999) considera que é preciso ir além da educação e desenvolver programas de envolvimento pró-ativo público, pois a educação consiste em comunicação unilateral e o envolvimento em comunicação bilateral, baseado nos seguintes princípios:

- programas que possuem interação com o público são freqüentemente a razão principal para o sucesso ou a falha na implementação de programas de recursos hídricos em áreas urbanas;

- o envolvimento público é determinado mais pelo número total de diferentes "públicos" que participam do que pelo número de indivíduos envolvidos;

- essencial para um programa de gerenciamento de recursos hídricos é a concordância entre público e profissionais sobre os problemas a serem prevenidos ou mitigados.

Nos empreendimentos da CDHU, a implementação de programas de educação ambiental não só solucionaria ou melhoraria a aceitação e o convívio com os reservatórios de detenção, mas também favoreceria todo o entorno através da conservação das áreas comuns e das demais benfeitorias coletivas, além de facilitar o diálogo com os diversos interlocutores. 


\section{DIRETRIZES GERAIS PARA INCORPORAÇÃO DE RESERVATÓRIOS DE DETENÇÃO NM NOVOS EMPREENDIMENTOS}

Os reservatórios de detenção assumem, cada vez mais, posição estratégica no combate às inundações urbanas e muitas vezes são considerados como a única solução possível para reduzir os transtornos causados pelas chuvas nas grandes cidades.

Apesar de ser um importante elemento de drenagem urbana, os reservatórios de detenção ainda enfrentam preconceitos de todos os tipos e sua implantação é constantemente contestada tanto por profissionais como pela população em geral, conforme foi possível notar nos estudos de casos apresentados.

É certo que ainda há um longo caminho a percorrer até que essas estruturas sejam incorporadas no dia a dia dos projetos e sua execução se torne corriqueira, entretanto, certos cuidados podem facilitar sua presença dentro do cenário urbano.

Como as variáveis envolvidas com a implantação de reservatórios de detenção são muitas e cada caso deve ser estudado de forma particular, mesmo havendo uma legislação que determine o volume de armazenamento necessário, apresenta-se aqui um roteiro com diretrizes gerais para orientação à implantação destes dispositivos em novos empreendimentos, de forma a tornar essa experiência menos traumática e mais eficiente.

As principais considerações a serem observadas são:

- Previsão dos reservatórios de detenção desde o início dos projetos

É essencial que seja diagnosticada a necessidade de implantação de reservatórios de detenção na fase inicial dos projetos, preferencialmente ainda na etapa de planejamento, pois esta falha é a principal causa dos atritos entre profissionais, de soluções pouco adequadas, de gastos excessivos ou de localização pouco privilegiada. 
A existência de legislações específicas e seu conteúdo devem ser conhecidos antecipadamente, para que se possa cumprir as determinações da lei, sem causar maiores transtornos ao empreendimento.

Oportunidades de implantação de reservatórios de detenção e a localização adequada dentro do empreendimento, também são pontos a serem identificados, explorados e trabalhados junto com os demais projetos, pois trata-se de condição favorável natural. Análises de estudos preliminares de urbanismo podem detectar essas oportunidades e equilibrar as soluções do partido urbanístico com a drenagem necessária.

O reservatório que não tiver sido planejado dentro do contexto urbanístico desde o começo dos trabalhos, fatalmente causará mudanças nos demais projetos, será motivo de rejeição por parte de outros profissionais, resultará em projetos de qualidade inferior e provocará atrasos nos cronogramas de obras. Além disso será implantado nos espaços que restarem e provavelmente se traduzirá numa obra de custo elevado e de difícil manutenção.

- Caracterização da bacia, dos atributos físicos do terreno, dos futuros moradores e dos responsáveis pelo reservatório;

O levantamento das características físicas da bacia de contribuição constituise num ponto fundamental da elaboração de projetos, pois essas são as informações que balizam a escolha entre as soluções possíveis e ditam suas características.

A configuração do terreno, o tipo de solo, as dimensões da bacia de contribuição, o uso e a ocupação do solo nesta bacia, a existência ou não de coleta regular de lixo, a qualidade da água e do escoamento superficial, a presença de redes de drenagem, etc. são parâmetros que condicionam a tipologia do reservatório.

O conhecimento dos moradores atuais e futuros da bacia, seu nível sóciocultural e financeiro, o grau de conscientização ambiental, a capacidade de organização e convívio em sociedade, além da sensibilidade aos problemas sociais, são também informações importantes que direcionam a concepção dos projetos e as precauções necessárias. 
Outro fator que deve ser considerado na elaboração dos projetos é a identificação dos responsáveis pela operação e manutenção dos reservatórios, uma vez que estas atividades devem ser condizentes com a capacidade de seus executores, inclusive no que diz respeito à condição financeira.

$\mathrm{O}$ descaso com as informações acima resultará em projetos inadequados e tendem ao abandono.

- Conhecimento do regime hidrológico local, dos problemas de drenagem urbana da bacia de contribuição e suas causas

Informações sobre o regime hidrológico local permitem conhecer as características particulares das precipitações que deverão ser controladas pelos reservatórios de detenção, e desta maneira, influem na escolha dos parâmetros e critérios de dimensionamento.

Propiciam também, a avaliação dos riscos a que as estruturas estarão sujeitas e facilitam a adoção de medidas preventivas.

O conhecimento dos problemas de drenagem existentes na bacia de contribuição torna mais claros os objetivos a serem alcançados e fornece subsídios para desenvolvimento das estruturas e para diálogo com os demais profissionais e com os futuros moradores.

Além disso, a identificação das causas desses problemas serve de indício sobre os hábitos da população, as atividades desenvolvidas na área da bacia e as providências a serem tomadas para melhorar o funcionamento dos reservatórios de detenção.

- Conhecimento das imposições das legislações específicas.

Legislações específicas sobre reservatórios de detenção são muito diferentes entre si e condicionam à elaboração dos projetos. 
É importante observar que só a determinação dos volumes, quando é fornecida uma equação para esta finalidade, não é condição suficiente para projetar um reservatório de detenção. Porém, uma certa simplificação embasada no planejamento da bacia é necessário, pois não se espera o desenvolvimento de estudos hidráulicos e hidrológicos completos a cada estudo de pequenas áreas.

Os dispositivos de entrada, saída e extravasão solicitam o conhecimento do embasamento da lei para que seus parâmetros de dimensionamento sejam coerentes com aqueles adotados para a determinação dos volumes de armazenamento.

Neste caso, se a legislação específica for um desdobramento do Plano Diretor de Drenagem Urbana, os estudos necessários e a verificação de sua eficiência, para um período de retorno determinado, deverão estar devidamente apresentados em seu conteúdo. Se esta não for a situação, é pertinente que sejam abordados no texto da lei ou que sejam fornecidas orientações pelos órgãos competentes, de modo a evitar efeitos adversos aos previstos.

- Definição das metodologias de cálculo

Nesta fase, o objetivo principal dos reservatórios de detenção deve estar definido, pois dependendo das finalidades a que se propõem estes dispositivos, os critérios e parâmetros de dimensionamento podem ser completamente diferentes.

Dados e informações provenientes de estudos, avaliações e monitoramento de sistemas existentes são fontes valiosas, assim como a vivência profissional da equipe técnica responsável, pois condições reais são diferentes de condições ideais.

Para cada caso, o conhecimento das metodologias existentes e seus limites de aplicação, somado a experiências práticas locais, são elementos essenciais que fundamentam e facilitam as escolhas.

Há no mercado, programas computacionais para estimativas de volumes e execução dos "routings", porém mesmo assim, é necessário conhecer seu funcionamento e suas restrições de usos. 
- Controle do aporte de sedimentos aos reservatórios e proteção dos dispositivos de entrada e saída

A produção de resíduos na bacia é a principal causa do insucesso dos reservatórios de detenção e por isso deve ter prioridade no desenvolvimento das ações, seja ela através da implantação de serviços, programas de educação ambiental ou cuidados na elaboração dos projetos.

O conhecimento prévio do estado dos sistemas de drenagem existentes e da qualidade da água do escoamento superficial fornece informações sobre os hábitos e atividades desenvolvidas na bacia e possibilita a adoção de medidas preventivas adequadas.

De qualquer forma, em maior ou menor quantidade, os resíduos sempre serão motivos de preocupação e de precaução, mesmo para bacias já consolidadas, cujas características são supostamente previsíveis.

Portanto, a proteção dos dispositivos de entrada e saída deve estar sempre em evidência, assim como as condições de acessibilidade ao dispositivo e facilidades de manutenção.

- Aumento de áreas permeáveis

Indiferentemente da existência ou não de problemas de drenagem ou de exigências legais, esta é uma meta a ser perseguida em todos os projetos, por todos os profissionais envolvidos.

É sempre de bom tom preservar as condições naturais de escoamento existentes, respeitando o ciclo hidrológico e os caminhos das águas pluviais dentro de uma determinada área.

Esse esforço resultará em projetos mais econômicos, de menores dimensões, de mais fácil implantação e tendem a ser melhor aceitos pela população.

É essencial também, a compreensão de que os reservatórios de detenção não se constituem em soluções isoladas, dependendo de outros fatores, como o controle da impermeabilização futura da bacia, para a otimização de seu uso. 
- Valorização dos reservatórios de detenção

Os reservatórios de detenção são normalmente vistos com ressalvas tanto pelos profissionais quanto pela população em geral.

Assim sendo, é necessário agregar valor a este dispositivo e aumentar a consciência de que ele só se torna necessário pela própria ação humana na bacia, no desenvolvimento de suas atividades.

A falta de valorização pode torná-lo elemento dispensável, favorecendo o acúmulo de lixo, sendo alvo de ocupações irregulares e tendendo ao abandono.

Possibilidades de valorização devem ser exploradas, seja através de usos múltiplos, seja através do apelo ambiental. Cabe a cada profissional procurar a vertente mais promissora e fazer uso dela com o máximo de criatividade.

Compensações financeiras, como a criação de incentivos públicos e facilidades para empreendimentos que contribuem com a redução do aumento do escoamento superficial, são elementos bastante sedutores e também valorizam os reservatórios de detenção. Entretanto podem ter atuação limitada.

Neste trabalho, experiências existentes demonstraram que é plenamente possível a convivência pacífica com esses dispositivos e que, se forem bem implantados, passarão despercebidos, trazendo inconvenientes mínimos e aumentando principalmente a possibilidade de criação de áreas verdes e de lazer.

A realidade demonstra que a implantação desses dispositivos exige mais conscientização e boa vontade do que grandes investimentos, principalmente quando incorporados ao planejamento da bacia hidrográfica e são excelentes indutores de cidadania e de preservação ambiental, devendo assim ser explorados.

- Compatibilização com os demais projetos

Apesar de óbvia, esta observação é importante, principalmente quando a necessidade de implantação dos reservatórios de detenção não é prevista desde o início do empreendimento. 
Para que este dispositivo funcione a contento, todas as interferências devem ser solucionadas ainda na fase de projeto e mantidas durante a execução, caso contrário, soluções improvisadas "in loco" podem ser desfavoráveis, se não forem inadequadas.

O estudo cuidadoso dos demais projetos e a detecção precoce de interferências abrem caminhos para o diálogo e tratativas com os demais profissionais, na busca de conciliações.

- Execução cuidadosa

De nada adiantarão as precauções acima, se a execução não for cautelosa e os projetos e suas recomendações não forem seguidos.

Na elaboração dos projetos, deve-se procurar a auto explicação dos sistemas, preferencialmente através de memoriais descritivos bem elaborados e de plantas claras e detalhadas. Quanto melhor explicado estiver um sistema, maior a chance de que seja executado de forma conforme, evitando desgastes posteriores desnecessários.

Esforço no fornecimento de material adequado para execução e fiscalização eficiente são também itens indispensáveis.

- Elaboração de manuais de operação e manutenção do sistema e de orientação aos usuários;

Trata-se de etapa importantíssima dentro do contexto do desenvolvimento de um reservatório de detenção, pois é a parte mais frágil tanto dos sistemas de drenagem como dos reservatórios.

O manual de operação e manutenção deve conter no mínimo, a descrição do funcionamento do reservatório, a forma de execução de cada tarefa de modo claro e preciso, a periodicidade de realização de cada uma dessas atividades, além da identificação de seus responsáveis. 
O manual de orientação aos usuários tem a finalidade básica de esclarecer os objetivos do reservatório de detenção, explicar seu funcionamento e orientar a forma correta de uso, prevenindo possíveis acidentes ou atividades indevidas.

Esses manuais devem ter linguagem acessível aos seus leitores e, se preciso for, conter figuras e desenhos ilustrativos para melhorar e reforçar seu conteúdo. Enquanto os reservatórios de detenção não forem dispositivos corriqueiros, formas de esclarecimento e conscientização são necessárias, principalmente para os futuros usuários.

- Monitoramento

O monitoramento se faz necessário para averiguar as condições de operacionalidade e manutenção dos reservatórios de detenção, detectar necessidade de acertos e também para subsidiar a elaboração de novos projetos.

Considerações teóricas, feitas durante o desenvolvimento dos projetos, podem se mostrar pouco efetivas ou insuficientes na prática e somente observações feitas durante o uso desses dispositivos serão capazes de fornecer informações precisas.

Além disso, com o aumento da freqüência de instalação, pode-se criar elementos de avaliação técnica e econômica que subsidiem negociações com a população e o poder público local.

A falta de monitoramento pode levar à reincidência de soluções inadequadas e colabora para o descrédito e desvalorização dos reservatórios de detenção.

- Segurança

Reservatórios de detenção favorecem a criação de ambientes pouco seguros e são propícios a usos ilícitos, aos quais os projetistas devem estar atentos e precavidos. 
É preciso verificar também as condições sanitárias e de uso, principalmente se forem utilizados para outros fins, diferentes do armazenamento dos volumes de escoamento superficial excedente.

Indiferentemente da finalidade nobre dos reservatórios de detenção, os profissionais envolvidos serão sempre os primeiros a serem responsabilizados na ocorrência de acidentes, mesmo que sejam fruto de usos inadequados ou ilícitos. 


\section{CONCLUSÕES E RECOMENDAÇÕES}

Observa-se hoje, que há uma cobrança muito grande da população para equacionamento dos problemas de inundações urbanas pelos seus governantes, sem perceber que parte dela o agravamento da situação existente, seja através da impermeabilização excessiva, da ocupação irregular ou da disposição incorreta do lixo.

As soluções da engenharia para controle das inundações são, na maioria das vezes, ações corretivas e não preventivas. Dentro do contexto das cidades, a prevenção e a amenização dos problemas de inundações estão muito mais na alçada dos administradores e urbanistas, que realmente definem o desenho urbano e fazem as especificações dos elementos a serem utilizados, do que nas "mãos da engenharia".

Municípios menores, em fase de desenvolvimento, devem estar atentos aos conceitos atuais de drenagem urbana, focada na preservação das características naturais existentes, para criar soluções adequadas com a realidade local e suas necessidades de crescimento, evitando processos inadequados de urbanização e os impactos ambientais observados nos grandes centros urbanos.

O desconhecimento e desvalorização dos reservatórios de detenção como medidas corretas e preventivas de controle da drenagem urbana, a dificuldade de mudanças em padrões arraigados e, até mesmo, um certo preconceito por parte de técnicos e proprietários, levantam barreiras difíceis de serem transpostas e exigem muita sensibilidade e discernimento dos profissionais envolvidos com a implantação dessas estruturas.

Legislações específicas sobre reservatórios de detenção têm tido o grande mérito de incorporar valores deixados em segundo plano, modificar formas de concepção dos projetos e exigir posturas diferenciadas dos técnicos perante questões urbanas. Porém, têm sido instituídas de forma pouco cuidadosa e consciente, dificultando sua utilização e a otimização dos sistemas de drenagem, concorrendo para o descrédito desta solução.

As restrições e dificuldades encontradas para aplicação da legislação específica do município de São Paulo, nos conjuntos habitacionais estudados, 
sugerem a necessidade de revisão para torná-la mais flexível e factível com as restrições de seus moradores. Além disso, a simples existência de equação para determinação de volumes em seu conteúdo, não soluciona as dificuldades encontradas no desenvolvimento desses projetos.

De qualquer forma, as legislações específicas devem ser fruto do planejamento da bacia hidrográfica e não de modismos casuais, promoção política ou intempestividade. Seu conteúdo deve ser claro, com objetivos definidos, coerente com as particularidades físicas e sociais da sua área de abrangência, e ao mesmo tempo, promover o aproveitamento das condições favoráveis existentes e incentivar a implantação concomitante de outras alternativas sustentáveis de drenagem urbana, visto que os reservatórios de detenção não se constituem em soluções isoladas e dependem de outros fatores para otimização de seu uso.

É necessário também, que haja incentivos ao seu cumprimento e que questões de fiscalização e de distribuição justa e eqüitativa do ônus do desenvolvimento, entre todos que dela se beneficiam, estejam solucionadas, sobretudo perante a distribuição irregular de responsabilidades e benefícios entre moradores de jusante e de montante de uma bacia hidrográfica.

A atualização dos cursos de graduação, principalmente de engenharia e arquitetura, além de cursos de especialização em drenagem urbana foram identificadas como atividades necessárias para melhorar a qualificação profissional e para subsidiar o desenvolvimento de soluções mais sustentáveis no contexto das cidades, pois quanto maior for o grau de conhecimento da equipe envolvida maior será a facilidade de comunicação e entendimentos.

O envolvimento multidisciplinar e a integração de profissionais são prérequisitos para a utilização dessas soluções e devem ser impulsionados através da criação de ambientes de trabalho onde vigore o dialogo, a cooperação e o respeito mútuo, considerando que é impossível o desenvolvimento unilateral deste tipo de projeto, posto que estará sujeito a todo tipo de críticas e poderá inclusive não ser implantado.

Existe ainda, um distanciamento entre conhecimento e prática, e que de forma geral, os técnicos responsáveis pela implantação de reservatórios de detenção sentem-se despreparados e inseguros para esta tarefa. 
A normatização e a regulamentação de formas básicas de dimensionamento, execução, manutenção e operação podem reverter essa situação, sendo bem vindas e necessárias para uniformização de critérios e balizamento de procedimentos. Essas atividades podem garantir maior tranqüilidade tanto para os profissionais como para a própria população.

O planejamento confirma-se como elemento central na adoção de medidas alternativas e tem como instrumentos principais os comitês de bacias, os planos diretores e as políticas fiscais, que a seu modo devem ser incentivados e explorados como indutores de sistemas de maior qualidade, seja pela organização e disciplinamento, pelo assessoramento técnico, pela participação ou pela viabilidade financeira.

Nas definições das políticas fiscais, particularmente tratando-se de população de baixa renda, deve-se ponderar sobre o alcance das medidas propostas, devido ao tratamento diferenciado deferido a ela, em função do interesse social.

A organização do arcabouço jurídico e institucional, a definição de papéis e responsabilidades entre diferentes órgãos gestores, a criação de instrumentos de consenso e a autonomia financeira para questões de recursos hídricos são também importantes atores na efetivação das alternativas para controle de cheias. Quanto melhor organizado estiverem, mais fácil será o encaminhamento das soluções e mais proveitoso será o resultado.

Relativamente às questões técnicas, a recomendação mais importante é a previsão da necessidade de implantação dos reservatórios de detenção desde o início dos trabalhos, o que vem a facilitar e melhorar todas as demais etapas.

Especial atenção deve ser dada também à fragilidade dos dispositivos de entrada e saída, que são estruturas de fácil obstrução e requerem manutenção constante. Não somente para este item, como também para a própria seleção de alternativas e precauções aplicáveis aos sistemas de drenagem, o conhecimento, controle e monitoramento da qualidade da água do escoamento superficial, fornecem informações preciosas que podem garantir a eficiência dos dispositivos projetados.

Operação e manutenção foram os principais problemas encontrados nos estudos de casos, seguidos de problemas construtivos e de falta de fidelidade ao projeto. Isso faz com que a elaboração de manuais de operação e manutenção, a 
identificação dos responsáveis por cada uma dessas atividades, a dotação orçamentária e o aprimoramento das relações entre projetos e obras tornem-se itens primordiais para o sucesso dos reservatórios de detenção.

Monitoramento e segurança completam o cenário. O primeiro por possibilitar a verificação de falhas, detectar necessidade de acertos e subsidiar a elaboração de novos projetos. O segundo, por prevenir acidentes e usos ilícitos, principalmente nos casos em que a finalidade dos reservatórios ultrapassam o controle de cheias.

O uso intermitente dos reservatórios de detenção, aliado à precariedade da condição financeira da população, pode criar a falsa impressão de que o espaço destinado à sua implantação deve ser melhor aproveitado e incentivar a ocupação ou o uso irregular. Para desfazer essas impressões, o aproveitamento múltiplo dos reservatórios e a integração paisagística apresentam-se como boas soluções, visto que aumentam sua aceitação pela população, agregam valor e podem garantir sua conservação.

Hoje, nota-se a expectativa da população em relação a esses usos múltiplos dos reservatórios de detenção e também uma inversão de valores, onde outras funções ganham relevância em relação ao controle de cheias.

Os custos de implantação mostraram-se pequenos quando comparados aos custos dos empreendimentos e variam sensivelmente conforme o tipo de dispositivo adotado. Os custos de inspeção, operação e manutenção, que também dependem do tipo de estrutura utilizada, sofrem variações ao longo do ano, de acordo com a periodicidade de execução de cada atividade, que está relacionada com a menor ou maior ocorrência de precipitações.

Pode-se dizer que a adoção deste tipo de solução não exige grandes investimentos, mas sim, conscientização e boa vontade.

Os objetivos de um reservatório de detenção só serão plenamente alcançados, se for desenvolvido um trabalho consistente de sensibilização e conscientização, para que haja um maior engajamento da população, em prol do seu valor comunitário, através da cooperação social, da aceitação e da participação.

A educação ambiental é um dos caminhos possíveis, pois proporciona o entendimento sobre o peso das atitudes individuais no meio ambiente, a relação entre o homem e os eventos críticos e a importância da conservação de características 
naturais, além de difundir práticas sustentáveis. Porém é um processo lento, de longa duração e difícil avaliação, que deve vir acompanhado de motivação e envolvimento.

A divulgação geralmente negativa dos reservatórios de detenção pela mídia dificulta esse trabalho de sensibilização e conscientização, assim como a postura dos órgãos governamentais, que passam a impressão de que se cobra da população atitudes que a própria administração pública não adota.

As soluções propostas pela CDHU quanto aos reservatórios de detenção ainda são tímidas e recentes, mas refletem o esforço do corpo técnico na busca de soluções apropriadas às características de seus empreendimentos e à integração destes com o meio ambiente.

As dificuldades e questões enfrentadas na implantação dos reservatórios de detenção em seus conjuntos habitacionais transparecem somente o "estado da arte" destes dispositivos, seja na área técnica, social ou política e demonstram o despreparo de todos: técnicos, governantes e população.

Até o momento, as tentativas da CDHU não têm sido bem sucedidas, pelas mais diversas razões, e indicam a necessidade de aprimoramento no desenvolvimento e implantação dessas estruturas e a busca de novas alternativas, mesmo que cerceadas pelas imposições de legislações municipais e de seu público alvo.

Formas clássicas de reservatórios devem ser evitadas e formas mais naturais e menos dependentes de operação e manutenção devem ser criadas. Algumas tentativas neste sentido têm sido elaboradas recentemente pela CDHU, porém ainda sem resultados práticos conclusivos.

A atuação estadual da CDHU permite que suas experiências e opiniões sejam difundidas vagarosamente nos municípios paulistas e por isso deve-se considerar sua importância na disseminação de conhecimentos e práticas, o que vem a aumentar sua responsabilidade perante as soluções propostas.

Enfim, os reservatórios de detenção são ainda dispositivos polêmicos, em fase de descobrimento e evolução, que gradativamente estão sendo incorporados ao cenário urbano e abrem caminhos para futuramente ser abraçados pela população, como mais um trunfo na luta pelo controle das inundações e aumento da qualidade de vida nas cidades. 
10 ANEXO A 


\section{Lei $\mathbf{n}^{0}$ 13.276, 04 de Janeiro de 2002}

Torna obrigatória a execução de reservatório para as águas coletadas por coberturas e pavimentos nos lotes, edificados ou não, que tenham área impermeabilizada superior a $500 \mathrm{~m}^{2}$.

HÉLIO BICUDO, Vice-Prefeito, em exercício no cargo de Prefeito do Município de São Paulo, no uso das atribuições que lhe são conferidas por lei, faz saber que a Câmara Municipal, em sessão de 27 de dezembro de 2001, decretou e eu promulgo a seguinte lei:

Art. $1^{\circ}$ - Nos lotes edificados ou não que tenham área impermeabilizada superior a $500 \mathrm{~m}^{2}$ deverão ser executados reservatórios para acumulação das águas pluviais como condição para obtenção do Certificado de Conclusão ou Auto de Regularização previstos na Lei 11.228, de 26 de junho de 1992.

Art. $2^{\circ}$ - A capacidade do reservatório deverá ser calculada com base na seguinte equação:

$\mathrm{V}=0,15 \times$ Ai $\times$ IP $\times \mathrm{t}$

$\mathrm{V}=$ volume do reservatório $(\mathrm{m} 3)$

$\mathrm{Ai}=$ área impermeabilizada $(\mathrm{m} 2)$

$\mathrm{IP}=$ índice pluviométrico igual a $0,06 \mathrm{~m} / \mathrm{h}$

$\mathrm{t}=$ tempo de duração da chuva igual a um hora.

$\S 1^{\circ}$ - Deverá ser instalado um sistema que conduza toda água captada por telhados, coberturas, terraços e pavimentos descobertos ao reservatório.

$\S 2^{\circ}$ - A água contida pelo reservatório deverá preferencialmente infiltrar-se no solo, podendo ser despejada na rede pública de drenagem após uma hora de chuva ou ser conduzida para outro reservatório para ser utilizada para finalidades não potáveis.

Art. $3^{\circ}$ - Os estacionamentos em terrenos autorizados, existentes e futuros, deverão ter $30 \%$ (trinta por cento) de sua área com piso drenante ou com área naturalmente permeável. 
$\S 1^{\circ}$ - A adequação ao disposto neste artigo deverá ocorrer no prazo de 90 (noventa) dias.

$\S 2^{\circ}$ - Em caso de descumprimento ao disposto no "caput" deste artigo, o estabelecimento infrator não obterá a renovação do seu alvará de funcionamento.

Art. $4^{\circ}$ - O Poder Executivo deverá regulamentar a presente lei no prazo de 60 (sessenta) dias.

Art. $5^{\circ}$ - Esta lei entrará em vigor na data de sua publicação, revogadas as disposições em contrário.

PREFEITURA DO MUNICÍPIO DE SÃO PAULO, aos 4 de janeiro de 2002, $448^{\circ}$ da fundação de São Paulo 


\section{Decreto $n^{0}$ 41.814, 15 de março de 2002}

Regulamenta a Lei ${ }^{\circ} 13.276$, de 4 de janeiro de 2002, que torna obrigatória a execução de reservatório para as águas coletadas por coberturas e pavimentos nos lotes, edificados ou não, que tenham área impermeabilizada superior a 500,00 m2.

MARTA SUPLICY, Prefeita do Município de São Paulo, no uso das atribuições que lhe são conferidas por lei,

\section{DECRETA:}

Art. $1^{\circ}$ - O reservatório previsto no artigo $1^{\circ}$ da Lei $n^{\circ} 13.276$, de 4 de janeiro de 2002, deverá ser exigido nos projetos de reformas e obras novas de edificações cujos pedidos de aprovação tenham sido protocolados após 5 de janeiro de 2002, de acordo com o disposto no artigo $2^{\circ}$ da referida lei, não eximindo do atendimento integral às exigências do item 10.1.5 do Anexo I da Lei n 11.228, de 25 de junho de 1992 (Código de Obras e Edificações).

$\S 1^{\circ}$ - O reservatório referido no "caput" deste artigo deverá ser fechado, coberto e atender às normas sanitárias vigentes.

$\S 2^{\circ}$ - Nos projetos de reforma e obra nova, deverá ser indicada a localização do reservatório e apresentado o cálculo do seu volume.

$\S 3^{\circ}$ - Quando aplicado o disposto na alínea "b" do item 10.1.5 da Lei $\mathrm{n}^{\circ} 11.228$, de 1992, o volume resultante da fórmula estabelecida no artigo $2^{\circ}$ da Lei $\mathrm{n}^{\circ} 13.276$, de 2002, deverá ser acrescido ao volume calculado pela fórmula definida no item 10.1.5.2 do Anexo I da Lei no 11.228, de 1992.

$\S 4^{\circ}$ - No caso de opção por conduzir as águas pluviais para outro reservatório, conforme previsto no $\S 2^{\circ}$ do artigo $2^{\circ}$ da Lei $n^{\circ} 13.276$, de 2002 , objetivando o reuso da água para finalidades não potáveis, deverá ser indicada a localização desse reservatório e apresentado o cálculo do seu volume.

Art. $2^{\circ}$ - Nas reformas, o reservatório previsto na Lei $\mathrm{n}^{\circ} 13.276$, de 2002, será exigido quando houver acréscimo de área impermeabilizada igual ou superior a 100,00 m2 (cem 
metros quadrados) e a somatória da área impermeabilizada existente e a construir resultar em área superior a 500,00 m2 (quinhentos metros quadrados).

$\S 1^{\circ}$ - O reservatório referido no "caput" deste artigo será calculado em relação à área impermeabilizada acrescida.

$\S 2^{\circ}$ - Quando houver reformas sucessivas de edificações cujos acréscimos, a cada pedido de reforma, não atingirem 100,00 m2 (cem metros quadrados) e a somatória das áreas acrescidas e aprovadas após 5 de janeiro de 2002, for igual ou superior a 100,00 m2 (cem metros quadrados), será exigido o reservatório dimensionado considerando-se toda a área impermeabilizada acrescida.

Art. $3^{\circ}$ - Nos projetos modificativos de obra nova de edificações aprovadas, anteriormente a 5 de janeiro de 2002, será exigido o atendimento às disposições da Lei $\mathrm{n}^{\circ}$ 13.276, de 2002, e deste decreto, apenas quando houver acréscimo de área impermeabilizada igual ou superior a $100,00 \mathrm{~m} 2$ (cem metros quadrados), sendo o reservatório calculado sobre toda a área impermeabilizada do projeto.

Parágrafo único - Ao projeto modificativo de reforma aplica-se o disposto no artigo $2^{\circ}$ deste decreto.

Art. $4^{\circ}$ - Os pedidos de regularização nos termos da Lei $n^{\circ}$ 8.382, de 13 de abril de 1976, protocolados após 5 de janeiro de 2002, deverão atender ao disposto na Lei $\mathrm{n}^{\circ} 13.276$, de 2002, e neste decreto.

Parágrafo único - Para execução do reservatório poderá ser concedida Notificação de Exigências Complementares - NEC, com prazo de 90 (noventa) dias, prorrogável por igual período.

Art. $5^{\circ}$ - Nos casos enquadrados neste decreto, por ocasião do pedido de Certificado de Conclusão ou de Auto de Regularização, deverá ser apresentada declaração assinada pelo Dirigente Técnico e pelo proprietário, de que a edificação atende à Lei $\mathrm{n}^{\circ} 13.276$, de 2002, e a este decreto, referente ao reservatório, com descrição sucinta do sistema instalado e, ainda, que o reservatório está de acordo com as normas sanitárias vigentes.

Art. $6^{\circ}-\mathrm{O}$ disposto no artigo $3^{\circ}$ da Lei $\mathrm{n}^{\circ} 13.276$, de 2002, aplica-se à atividade 
estacionamento e não exime do atendimento ao item 13.3.8 do Anexo I da Lei n ${ }^{\circ}$ 11.228, de 1992.

$\S 1^{\circ}$ - A adequação ao disposto neste artigo deverá ocorrer no prazo de 90 (noventa) dias, a partir da data de publicação deste decreto.

$\S 2^{\circ}$ - Para a atividade estacionamento, regularizada ou licenciada anteriormente à Lei $n^{\circ}$ 11.228, de 1992, que solicitar renovação de licença de funcionamento, esta somente será emitida se comprovado, por meio de fotografias, o atendimento ao artigo $3^{\circ}$ da Lei $n^{\circ}$ 13.276, de 2002. $\S 3^{\circ}$ - Para a atividade estacionamento, licenciada após a Lei $\mathrm{n}^{\mathrm{o}} 11.228$, de 2002, prevalece o disposto no item 13.3.8 do Anexo I da Lei no 11.228, de 1992.

$\S 4^{\circ}$ - No caso de descumprimento ao disposto neste artigo e em seus parágrafos, não será concedido ou renovado o Alvará de Autorização ou a Licença de Funcionamento.

Art. $7^{\circ}$ - $\mathrm{O}$ disposto no artigo $3^{\circ}$ da Lei $\mathrm{n}^{\circ} 13.276$, de 2002, aplica-se também às reformas nos estabelecimentos destinados à atividade estacionamento, licenciados anteriormente à Lei $\mathrm{n}^{\circ} 11.228$, de 1992, ou regularizados.

Art. $8^{\circ}$ - No projeto que configure o desdobro de lotes, o disposto na Lei $\mathrm{n}^{\circ} 13.276$, de 2002, e neste decreto aplica-se a cada lote resultante.

Art. $9^{\circ}$ - Este decreto entrará em vigor na data de sua publicação, revogadas as disposições em contrário.

PREFEITURA DO MUNICÍPIO DE SÃO PAULO, aos 15 de março de 2002, 449 da fundação de São Paulo. 


\section{Exemplo Numérico}

Para elucidação do volume de armazenamento resultante da aplicação da equação existente na legislação municipal de São Paulo, apresenta-se o exemplo numérico abaixo:

a) Dados do terreno:

- Área total $=11.091,00 \mathrm{~m}^{2}$

- Áreas das edificações $=2.211,00 \mathrm{~m}^{2}$

- Área de tráfego de veículos $=2.597,00 \mathrm{~m}^{2}$

- Área impermeabilizada $=4.808,00 \mathrm{~m}^{2}$

b) Equação existente na legislação:

$$
\mathrm{V}=0,15 \times \mathrm{Ai} \times \operatorname{IP} \times \mathrm{t}
$$

Onde: $\mathrm{V}=$ volume do reservatório $\left(\mathrm{m}^{3}\right)$

$\mathrm{Ai}=$ área impermeabilizada $\left(\mathrm{m}^{2}\right)$

$\mathrm{IP}=$ índice pluviométrico igual a $0,06 \mathrm{~m} / \mathrm{h}$

$\mathrm{t}=$ tempo de duração da chuva igual a um hora.

c) Determinação do volume de armazenamento:

$$
\begin{aligned}
& \mathrm{V}=0,15 \times \text { Ai } \times \text { IP } \times \mathrm{t} \\
& \mathrm{V}=0,15 \times 4.808,00 \times 0,06 \times 1 \\
& \mathrm{~V}=43,27 \mathrm{~m}^{3}
\end{aligned}
$$


11 ANEXO B 


\section{Decreto de Regulamentação Municipal para Controle da Drenagem Urbana Proposto para Porto Alegre}

Regulamenta o controle da drenagem urbana

O Prefeito Municipal de Porto Alegre, usando de suas atribuições legais e tendo em vista os Art. 97 e Art. 135 § 6o da Lei Complementar 434/99 e considerando que:

- compete ao poder público prevenir o aumento das inundações devido à impermeabilização do solo e canalização dos arroios naturais;

- o impacto resultante da impermeabilização produz aumento de freqüência de inundações, piora da qualidade da água e aumento do transporte de material sólido, degradando o ambiente urbano;

- deve ser responsabilidade de cada empreendedor a manutenção das condições prévias de inundação nos arroios da cidade, evitando-se a transferência para o restante da população do ônus da compatibilização da drenagem urbana;

- a preservação da capacidade de infiltração das bacias urbanas é prioridade para a conservação ambiental dos arroios e rios que compõem a macrodrenagem e dos rios receptores do escoamento da cidade de Porto Alegre.

Declara que:

Art. 1o Toda ocupação que resulte em superfície impermeável, deverá possuir uma vazão máxima específica de saída para a rede pública de pluviais menor ou igual a 20,8 1/(s.ha).

§ 1o A vazão máxima de saída é calculada multiplicando-se a vazão específica pela área total do terreno.

§ 2o Serão consideradas áreas impermeáveis todas as superfícies que não permitam a infiltração da água para o subsolo.

§ 3o A água precipitada sobre o terreno não pode ser drenada diretamente para ruas, sarjetas e/ou redes de drenagem excetuando-se o previsto no $\S 40$ deste artigo.

$\S 40$ As áreas de recuo mantidas como áreas verdes poderão ser drenadas diretamente para o sistema de drenagem. 
$\S 50$ Para terrenos com área inferior a $600 \mathrm{~m} 2$ e para habitações unifamiliares, a limitação de vazão referida no caput deste artigo poderá ser desconsiderada, a critério do Departamento de Esgoto Pluviais.

Art. 2o Todo parcelamento do solo deverá prever na sua implantação o limite de vazão máxima específica disposto no Art. 1o .

Art. 3o A comprovação da manutenção das condições de pré-ocupação no lote ou no parcelamento do solo deve ser apresentada ao DEP (Departamento de Esgoto Pluviais).

§ 1o Para terrenos com área inferior a 100 (cem) hectares quando o controle adotado pelo empreendedor for o reservatório, o volume necessário do reservatório deve ser determinado através da equação:

$$
\mathrm{v}=4,25 \mathrm{AI}
$$

onde v é o volume por unidade de área de terreno em m3/hectare e AI é a área impermeável do terreno em \%.

§ 2o O volume de reservação necessário para áreas superiores a 100 (cem) hectares deve ser determinado através de estudo hidrológico específico, com precipitação de projeto com probabilidade de ocorrência de $10 \%$ em qualquer ano (Tempo de retorno $=10(\mathrm{dez})$ anos.

§ 3o Poderá ser reduzida a quantidade de área a ser computada no cálculo referido no §1o se for (em) aplicada(s) a(s) seguinte(s) ação (ões):

- Aplicação de pavimentos permeáveis (blocos vazados com preenchimento de areia ou grama, asfalto poroso, concreto poroso) - reduzir em $50 \%$ a área que utiliza estes pavimentos;

- Desconexão das calhas de telhado para superfícies permeáveis com drenagem reduzir em $40 \%$ a área de telhado drenada;

- Desconexão das calhas de telhado para superfícies permeáveis sem drenagem reduzir em $80 \%$ a área de telhado drenada; 
- Aplicação de trincheiras de infiltração - reduzir em $80 \%$ as áreas drenadas para as trincheiras.

§ 4o A aplicação das estruturas listadas no § 3o estará sujeita a autorização do DEP, após a devida avaliação das condições mínimas de infiltração do solo no local de implantação do empreendimento, a serem declaradas e comprovadas pelo interessado.

§ 5o As regras de dimensionamento e construção para as estruturas listadas no § 3o bem como para os reservatórios deverão ser obtidas no Manual de Drenagem Urbana do Plano Diretor de Drenagem Urbana de Porto Alegre.

Art. 4o Após a aprovação do projeto de drenagem pluvial da edificação ou do parcelamento por parte do DEP, é vedada qualquer impermeabilização adicional de superfície.

Parágrafo Único: A impermeabilização poderá ser realizada se houver retenção do volume adicional gerado de acordo com a equação do Art. 3o §1o.

Art. 5o Os casos omissos no presente decreto deverão ser objeto de análise técnica do Departamento de Esgotos Pluviais.

Art. $6^{\circ}$ Este decreto entrará em vigor na data de sua publicação, revogadas as disposições em contrário.

Prefeitura Municipal de Porto Alegre. 


\section{Exemplo Numérico}

O volume de armazenamento resultante da aplicação da equação existente na legislação municipal de Porto Alegre, utilizando-se os mesmos valores adotados para São Paulo:

a) Dados do terreno:

- Área total $=11.091,00 \mathrm{~m}^{2}(1,11 \mathrm{ha})$

- Áreas das edificações $=2.211,00 \mathrm{~m}^{2}$

- Área de tráfego de veículos $=2.597,00 \mathrm{~m}^{2}$

- Área impermeabilizada $=4.808,00 \mathrm{~m}^{2}(43,4 \%)$

b) Equação existente na legislação:

$$
\mathrm{v}=4,25 \times \mathrm{Ai}
$$

Onde: $v=$ volume por unidade de área do terreno $\left(\mathrm{m}^{3} / \mathrm{ha}\right)$

$$
\mathrm{Ai} \text { = área impermeável }(\%)
$$

c) Determinação do volume de armazenamento:

$$
\begin{aligned}
& \mathrm{v}=(4,25 \times \mathrm{Ai}) \times \text { (área do terreno) } \\
& \mathrm{v}=4,25 \times 43,4 \times 1,11 \\
& \mathrm{~V}=204,74 \mathrm{~m}^{3}
\end{aligned}
$$

d) Utilizando-se as reduções de áreas permitidas pela legislação para diferentes ações, poderia-se chegar aos seguintes volumes:

\begin{tabular}{|l|c|c|c|c|}
\hline Ação & Redução $(\%)$ & Redução $\left(m^{2}\right)$ & $A I(\%)$ & $V\left(m^{3}\right)$ \\
\hline Pavimentos permeáveis & 50 & $1.298,5$ & 31,64 & 149,27 \\
\hline Desconexão de calhas & 40 & 884,40 & 35,38 & 166,89 \\
\hline Trincheira de infiltração & 80 & $3.846,40$ & 8,67 & 40,90 \\
\hline
\end{tabular}




\section{REFERÊNCIAS BIBLIOGRÁFICAS}

ABES-SP. São Paulo. Fórum lixo e cidadania. Disponível em: <www.abessp.org.br>. Acesso em nov. 2004.

AGRA, S. G; GOLDENFUM, J. A. Análise da eficiência de um microrreservatório no controle do escoamento. In: SEMINÁRIO DE DRENAGEM URBANA DO MERCOSUL, I; SEMINÁRIO NACIONAL DE DRENAGEM URBANA,V, Porto Alegre, 2001. Soluções para a drenagem urbana em países da América Latina: resumos. Porto Alegre: ABRH, 2001. p.7-12.

ANA. Brasília. Legislação sobre recursos hídricos. Disponível em <www.ana.gov.br/institucional/default.asp>. Acesso em: mai. 2005.

ANDOH, R. Y. G. Urban drainage - the alternative approach. In: WEDC, $20^{\text {th }}$, Sri Lanka, 1994. Conference of affordable water supply and sanitation. Disponível em <http://infolboro.ac.uk/departments/cv/wedc/paper/andoh.html>. Acesso em: nov. 2004.

ARAÚJO, P. R.; GOLDENFUM, J.; TUCCI, C. E. M. Avaliação experimental de pavimentos permeáveis no controle da geração de escoamento superficial. In: SIMPÓSIO BRASILEIRO DE RECURSOS HÍDRICOS, XIII, Belo Horizonte, 1999. Anais. [S.I.]: ABRH, 1999. 5p.1 CD-ROM.

ASCE Stormwater detention outlet control structures. In: Task committee on design of outlet control structures, American society of civil engineers. New York: 1985. p.1-33.

AZZOUT, Y.; BARRAUD, F. N. CRES; ALFAKIH, E. Decision aids for alternative techniques in urban storm management, Water Science and Technology, v.32, n.1, p.41-48, 1995. 
BARROS, M. T. L. de A questão das águas nas grandes cidades brasileiras: Workshop Escola Politécnica da Universidade de São Paulo. São Paulo: dez. 2003. $172 \mathrm{p}$.

Gerenciamento Integrado de Bacias Hidrográficas em Áreas Urbanas, Sistema de Suporte do Gerenciamento da Água Urbana, Estudo de Caso: Rio Cabuçu de Baixo. São Paulo: 2004. 52p.

BINDER, W. Rios e córregos, preservar - conservar - renaturalizar. 3.ed. Rio de Janeiro: Secretaria de Estado de Meio Ambiente e Desenvolvimento Sustentável do Estado do Rio de Janeiro, Projeto PLANÁGUA SEMADS/GTZ, 1998.

BRAUNE, M. J.; WOOD, A. Best management practices applied to urban runoff quantity and quality control, Water Science and Technology, v.39, n.12, p.117-121, 1999.

CAESB Medidas para controle do escoamento superficial na bacia do Lago Paranoá. Brasília: DRSE; SPEE, 2003. 6p.

CANHOLI, A. P. Soluções estruturais não-convencionais em drenagem urbana, 1995. 300p. Tese (doutorado) - Escola Politécnica, Universidade de São Paulo. São Paulo, 1995.

São Paulo, 2000. O plano diretor de macrodrenagem na bacia do alto Tietê - formulação, diretrizes e resultados iniciais. Disponível em: <www.brasilengenharia.com.br/PlanoDiretorMacrodrenagem548.htm>. Acesso em: out. 2004.

. São Paulo, 2002. O programa de controle das inundações na bacia do Aricanduva. 
<www.phd.poli.usp.br/phd/pos/phd5033/material/controle/inundações/controleinund ações.pdf>. Acesso em: nov. 2004.

CASQA. Califórnia, 2003. Califórnia stormwater BMP handbook - new development and redevelopment. Disponível em: <www.cabmphandbook.com>. Acesso em: dez. 2004.

CBH-AT. São Paulo, 2002. Plano da bacia hidrográfica do alto Tietê V.2.0, Caderno Institucional. Disponível em: <www.sigrh.sp.gov.br/cgibin/sigrh_home_colegiado.exe.?colegiado=CRH\%2FCBHAT\&TEMA=RELATÓRIO>. Acesso em: mai. 2005.

São Paulo, 2002a. Plano da bacia hidrográfica do alto Tietê V.2.0, Sumário Executivo. Disponível em: <www.sigrh.sp.gov.br/arqs/relatorio/CBH/CBHAT/559/sumário\%20executivo\%20v2.pdf>. Acesso em: mai. 2005.

CDHU Perfil Sócio-econômico e habitacional das famílias cadastradas, estudos preliminares, programa SH3. São Paulo: Gerência de pesquisa social, 1992. 63p.

Necessidade de integração dos escritórios regionais para cumprimento de metas. In: ENCONTRO DO ESCRITÓRIOS REGIONAIS, I, São Paulo, 2003. São Paulo, 2003. 28p.

Programas PRÓ-LAR - síntese dos manuais. São Paulo: Superintendência de planejamento estratégico, 2004. 15p.

—. São Paulo. Informações acerca da CDHU. Disponível em: <www.cdhu.sp.gov.br>. Acesso em: out./nov. 2004.

CDHU/SEADE Programa de habitação da CDHU, Pesquisa socioeconômica e inscrições de famílias. São Paulo: 1998. 
Diagnóstico das condições habitacionais no estado de São Paulo. São Paulo: 2001.

CDHU/FIA Delineamento de cenário e revisão da política habitacional do Estado de São Paulo. São Paulo, 2002. (relatório no ${ }^{\text {12). }}$.

CETESB. São Paulo. Qualidade da água da chuva. Disponível em: <www.cetesb.sp.gov.br/Águas/rios/gesta_asp> <www.cetesb.sp.gov.br/gesta_reuso.asp>. Acesso em: mai. 2005.

_. Drenagem urbana - manual de projetos. 3.ed. São Paulo: ASCETESB, 1986.

Constituição da República Federativa do Brasil. Brasília: Assembléia Nacional Constituinte, IMESP, 05 out. 1988. 48p.

Constituição do Estado de São Paulo. São Paulo: Assembléia Legislativa, Sala das Sessões, 05 out. 1989. Disponível em: <www.legislacao.sp.gov.br>. Acesso em: dez. 2004.

COSTA, A. C. M.; SANTOS, M. A. Gestão de recursos hídricos: legislação e cidadania. In: SIMPÓSIO BRASILEIRO DE RECURSOS HÍDRICOS, XIII, Belo Horizonte, 1999. Anais. [S.I.]: ABRH, 1999. 5p. 1 CD-ROM.

CRUZ, M. A. S.; AGRA, S. G. Microrreservatório e chuvas reais. In: SEMINÁRIO DE DRENAGEM URBANA DO MERCOSUL, I; SEMINÁRIO NACIONAL DE DRENAGEM URBANA,V, Porto Alegre, 2001. Soluções para a drenagem urbana em países da América Latina: resumos. Porto Alegre: ABRH, 2001. p.5156.

CRUZ, M. A. S.; ARAÚJO, P. R.; SOUZA, V. C. B. Estruturas de controle do escoamento urbano na microdrenagem. In: SIMPÓSIO BRASILEIRO DE 
RECURSOS HÍDRICOS, XIII, Belo Horizonte, 1999. Anais. [S.I.]: ABRH, 1999. 12p. 1 CD-ROM.

CRUZ, M. A. S.; TUCCI, C. E. M.; SILVEIRA, A. L. L. da. Medidas de controle do escoamento urbano. Controle do escoamento em lotes urbanos com detenção. In: TUCCI, C. E. M.; MARQUES, D. M. L. M. Avaliação e controle da drenagem urbana. Porto Alegre: Editora da Universidade/UFRGS, 2000. p.363-382.

CUNDOM, G.; GUTIERREZ, G. Impacto cero en el drenaje pluvial urbano. In: SEMINÁRIO DE DRENAGEM URBANA DO MERCOSUL, I; SEMINÁRIO NACIONAL DE DRENAGEM URBANA,V, Porto Alegre, 2001. Soluções para a drenagem urbana em países da América Latina: resumo. Porto Alegre: ABRH, 2001. p.57-62.

CUNHA, E. C. N.; VEIGA, A. P.; KELMAN, J. Domínio e competência sobre os recursos hídricos no Brasil. Revista Justiça \& Cidadania, [s.n.], [S.I.], p.22-25, abr. 2004.

DAEE. São Paulo. Informações acerca dos piscinões. Disponível em: <www.daee.sp.gov.br/piscinoes/index.htm>. Acesso em: out. 2004.

São Paulo: 1998. Revista água e energia elétrica. Disponível em: <www.daee.sp.gov.br/acervoepesquisa/relatorios/revista/raee9810/piscinoes.html>. Acesso em: set. 2004.

São Paulo: 1998a. Revista água e energia elétrica. Disponível em: <www.daee.sp.gov.br/piscinoes/materia01.htm>. Acesso em: set. 2004.

Bacia superior do ribeirão dos meninos - diagnóstico geral e ações recomendadas. São Paulo: 1999. (Relatório PDAT1-HI-RT-237, Conceituação das principais soluções preconizadas). 
Relatório de avaliação e limpeza. São Paulo: Programa de combate às enchentes na bacia hidrográfica do alto Tamanduateí, Controle Operacional e Monitoramento, 2000.

Decreto Municipal $n^{0}$ 41.814. Regulamenta a Lei $n^{\circ} 13.276$, de 4 de Janeiro de 2002. São Paulo: Prefeitura do Município de São Paulo, 15 mar. 2002.

EMPLASA O problema das inundações na grande São Paulo: situação atual e implementação de diretrizes metropolitanas de drenagem, São Paulo, 1985. p.2325.

ESTATUTO DA CIDADE. Brasília: 2004. Disponível em: <www.estatutodacidade.org.br>. Acesso em: dez. 2004.

FENDRICH, R. Reservatórios de detenção distribuída das águas pluviais na drenagem urbana de curitiba - PR In: SIMPÓSIO BRASILEIRO DE RECURSOS HÍDRICOS, XV, Curitiba, 2003. Anais. [S.I.]: ABRH, 2003. 16p. 1 CD-ROM.

Detenção concentrada versus distribuída das águas pluviais no controle das enchentes urbanas. In: SIMPÓSIO BRASILEIRO DE RECURSOS HÍDRICOS, XV, Curitiba, 2003a. Anais. [S.I.]: ABRH, 2003. 14p. 1 CD-ROM

FIORAVANTI, C. Enchentes - as águas encontram saídas. Revista pesquisa FAPESP, São Paulo, n.103, p.78-83, set. 2004.

GOMES, C. A. B. de M.; BAPTISTA, M. B.; NASCIMENTO, N. O. A legislação brasileira e o uso de técnicas alternativas de drenagem urbana. In: SIMPÓSIO BRASILEIRO DE RECURSOS HÍDRICOS, XV, Curitiba, 2003. Anais. [S.I.]: ABRH, 2003. 17p. 1 CD-ROM. 
GRACIOSA, M. C. P. Trincheiras de infiltração como tecnologia alternativa em drenagem urbana, 2004. 108p. Dissertação (Qualificação Mestrado) - Escola de Engenharia de São Carlos, Universidade de São Paulo. São Carlos, 2004.

HELMER, R.; HESPANHO, I.; SALIBA, L. J. Public health criteria for the aquatic environment: recent WHO guidelines and their application, Water Science and Technology, v.24, n.2, p. 35-42, 1991.

HYDROAID Third course HYDROAID 2004. Post-graduate Specialization Course in Management of Water Resources and Services. Turim, Italy, 2004.

IBGE Anuário estatístico do Brasil - 1997, Rio de Janeiro, 1998.

IBGE. Rio de Janeiro, 2002. Pesquisa nacional de saneamento básico 2000. Diretoria de Pesquisas, Departamento de População e Indicadores Sociais. Disponível em: <www.ibge.gov.br/hoem/estatistica/população/condiçãodevida/pnsb/pnsb.pdf>. Acesso em: nov. 2004.

JICA Construction engineering II (civil works). Curso de treinamento em grupo. Osaka, Japão, 1996.

Lei Estadual $\mathbf{n}^{\mathbf{0}}$ 6.556, Imposto sobre operações relativas à circulação de mercadorias e prestação de serviços - ICMS. São Paulo: Assembléia Legislativa Estadual, 30 nov. 1989.

Lei Estadual no 7.633, Política estadual de recursos hídricos. São Paulo: Assembléia Legislativa, 30 dez. 1991.

Lei Federal $n^{\mathbf{0}}$ 9.433, regulamenta o inciso XIX, do artigo 21, da Constituição Federal, e institui a Política Nacional de Recursos Hídricos e o Sistema Nacional de Recursos Hídricos. Brasília: Congresso Nacional, 8 jan. 1997. 
Lei Federal $\mathbf{n}^{\mathbf{0}}$ 10.257, Estatuto da Cidade - regulamenta os artigos 182 e 183 da Constituição Federal, estabelece diretrizes gerais da política urbana e dá outras providências. Brasília: Congresso Nacional, 10 jul. 2001.

Lei Municipal $\mathbf{n}^{0}$ 11.228, Código de obras e edificações. São Paulo: Prefeitura do Município de São Paulo, 25 jun. 1992.

Lei Municipal $\mathbf{n}^{\mathbf{0}}$ 13.276, institui a execução de reservatório para as águas coletadas por coberturas e pavimentos nos lotes, edificados ou não, que tenham área impermeabilizada superior a $500 \mathrm{~m}^{2}$. São Paulo: Prefeitura do Município de São Paulo, 04 jan. 2002.

LID-Center. USA, 2003. Low impact development urban design tools. Disponível em: 〈www.lid-stormwater.net>. Acesso em: dez. 2004.

LOUCKS, E.D.. In: ANNUAL CONFERENCE ON WATER RESOURCES PLANNING AND MANAGEMENT, 25 $5^{\text {th }}$, Chicago, 1998. Water resources and the urban environment: proceedings. USA: ASCE, 1998. 805p.

MARIN, M. C. F. C.; ROSÁRIO, C. S.; RAMOS, F. A.; TAMAROZI, R. Planejamento do sistema de drenagem urbana: concepção ideal versus prática do poder. In: SIMPÓSIO BRASILEIRO DE RECURSOS HÍDRICOS, XIII, Belo Horizonte, 1999. Anais. [S.I.]: ABRH, 1999. 11p. 1 CD-ROM.

MARKROPOULOS, C.; BUTLER, D.; MAKSIMOVIC, C. Gis supported evaluation of source control applicability in urban areas, Water Science and Technology, v.39, n.9, p.243-252, 1999.

MASCARENAS, F.; MIGUEZ, M.; CAMPOS, R.; D’ALTÉRIO, C. Drenagem urbana na bacia do Rio Trapicheiro, Rio de Janeiro, RJ. In: SEMINÁRIO DE DRENAGEM URBANA DO MERCOSUL, I; SEMINÁRIO NACIONAL DE 
DRENAGEM URBANA,V, Porto Alegre, 2001. Soluções para a drenagem urbana em países da América Latina: resumos. Porto Alegre: ABRH, 2001. p.111116.

McCUEN, R. H.; WALESH, S. G.; RAWIS, W. J. Control of urban stormwater runoff by detention and retention. Washington: United States Department of Agriculture, Agricultural Research Service, 1983. (Miscellaneous publication number 1428).

MEDEIROS, Y. D. P. Participação do poder local no gerenciamento de recursos hídricos. In: SIMPÓSIO BRASILEIRO DE RECURSOS HÍDRICOS, XIII, Belo Horizonte, 1999. Anais. [S.I.]: ABRH, 1999. 7p. 1 CD-ROM.

MELO, F. et al. Análise de caso de drenagem urbana a sudoeste da planície de Recife. In: SEMINÁRIO DE DRENAGEM URBANA DO MERCOSUL, I; SEMINÁRIO NACIONAL DE DRENAGEM URBANA,V, Porto Alegre, 2001. Soluções para a drenagem urbana em países da América Latina: resumos. Porto Alegre: ABRH, 2001. p.117-121.

MCIDADES. Brasília. Credenciamento de consultores e capacitadores para elaboração de planos diretores participativos. Disponível em: <www.cidades.gov.br>. Acesso em: dez. 2004.

MMA. Brasília. Sistema Nacional de Gerenciamento de Recursos Hídricos. Disponível em: <www.mma.gov.br/port/srh/sistema/comites.html>. Acesso em: dez. 2004.

MOELLER, G.; LIPPNER, G. Practicability of detention basins for treatment of Caltrans highway runoff based on a maximum extent practicable evaluation. In: ANNUAL MEETING OF TRANSPORTATION RESEARCH BOARD, $8^{\text {th }}$, Washington, 2001. DC, Disponível em: <www.owp.csus.edu/research/papers/papers/PP021.pdf>. Acesso em: nov. 2004. 
MUC. Minnesota, 2004. Minnesota urban small sites BMP manual, detention systems, dry ponds. Barr Engineering and Co. Disponível em: <www.metrocouncil.org/envirnment/watershed/bmp/CH3_STDetDryPond.pdf > Acesso em: nov. 2004.

NASCIMENTO, N.O.; ELLIS, J. B.; DEUTSCH, J. C. Using detention basins: operational experience and lessons. Urban Water, v.1, p.113-124, 1999.

NETO, A. C. Brasília. Sistemas urbanos de drenagem. Disponível em: <www.ana.gov.br/portalconhecimento/AntonioCardosoNeto/Introdução_a_drenagem _urbana.pdf>. Acesso em: out. 2004.

NETTO, O. M. C. Brasília, 2003. A questão da drenagem urbana no Brasil elementos para formulação de uma política nacional de drenagem. Programa de modernização do setor saneamento, versão 1. Disponível em: <www.snis.gov.br/arquivos/publicações/outros/TextoDrenagemFinal_1.pdf >.Acesso em: dez. 2004.

OLIVEIRA, C. DE Critérios de projeto para estruturas de reservação em drenagem urbana. 2004. 149p. Dissertação (Mestrado) - Escola Politécnica, Universidade de São Paulo. São Paulo, 2004.

OYAKAWA, K. A. O. São Paulo, 2002. Manutenção do reservatório de detenção AM-3 no município de Santo André In: EXPOSIÇÃO DE EXPERIÊNCIAS MUNICIPAIS EM SANEAMENTO, VII. Disponível em: <www.semasa.sp.gov.br/Documentos/ASSEMAE/Trab_60.pdf>. Acesso em: dez. 2004.

PARKINSON, J. Goiás. Stormwater management and urban drainage in developing countries. Disponível em: <www.ufg.br>. Acesso em: jan. 2005. 
PARKINSON, J.; MILOGRANA, J.; CAMPOS, L. C.; CAMPOS, R. Drenagem urbana sustentável no Brasil. Goiânia: Universidade Federal de Goiás, Loughborough University, 2003. (Relatório do workshop de 7 de maio de 2003). Disponível em: <www.abctransmisul.com.br/relatori.pdf>. Acesso em: nov. 2004.

PERSON, J.; SOMES, N. L. G.; WONG, T.H.F. Hydraulics efficiency of constructed wetlands and ponds. Water Science and Technology, v.40, n.3, p.291-300, 1999.

PIEL, C.; PEREZ, I.; MAYTRAUD, T. Three examples of temporary stormwater catchments in dense urban areas: a sustainable development approach. Water Science and Technology, v.39, n.2, p. 25-32, 1999.

PMSP/FCTH Diretrizes básicas para projetos de drenagem urbana no município de São Paulo, São Paulo, 1999. 289p.

PORTO, R. L. L.; FILHO, K. Z. Retenção e detenção. Disciplina do curso de especialização em Gestão do Ambiente Construído: Planejamento e Intervenção. São Paulo: CDHU, 2004.

PORTO, R. M. Análise de desempenho de bacias de detenção. In: BRAGA, B.; TUCCI, C.; TOZZI, M. Drenagem Urbana: Gerenciamento, simulação e controle. Porto Alegre: editora UFRGS/ABRH, 1998. p.177-187.

QUADROS, C. Estatuto da Cidade: Lei no 10.257, de 10/7/2001. 1.ed. São Paulo: Editora NDJ Ltda, 2001.

SÁNCHES, J. L. Regulación del uso del suelo en áreas urbanas. In: SEMINÁRIO DE DRENAGEM URBANA DO MERCOSUL, I; SEMINÁRIO NACIONAL DE DRENAGEM URBANA,V, Porto Alegre, 2001. Soluções para a drenagem urbana em países da América Latina: resumos. Porto Alegre: ABRH, 2001. p.175180. 
SANTOS, M. C. DOS Águas revoltas: história das enchentes em Santo André. Santo André: Semasa, PMSA, 2002.

SCOTT, P.; SANTOS, R.; ARGUE, J. R. Performance, environmental and cost comparisons of onsite detention (OSD) and onsite retentions (OSR) in re-developed residential catchments. Water Science and Technology, v.39, n.2, p. 33-41, 1999.

SIEKER, F. On-site stormwater management as an alternative to conventional sewer systems: a new concept spreading in Germany. Water Science and Technology, v.39, n. 10, p. 65-71, 1998.

SIEKER, F.; KLEIN, M. Best management practices for stormwater - runoff with alternative methods in a large urban catchment in Berlin, Germany. Water Science and Technology, v.39, n.10, p. 91-97, 1998.

SICKERMANN, J. M. Uso das águas de chuva: o futuro viável das grandes cidades do Brasil. In: SEMINÁRIO DE DRENAGEM URBANA DO MERCOSUL, I; SEMINÁRIO NACIONAL DE DRENAGEM URBANA,V, Porto Alegre, 2001. Soluções para a drenagem urbana em países da América Latina: resumos. Porto Alegre: ABRH, 2001. p.191-196.

SOUZA, V. C. B.; GOLDENFUM, J. A. Trincheiras de infiltração como elemento de controle do escoamento superficial: um estudo experimental. In: SIMPÓSIO BRASILEIRO DE RECURSOS HÍDRICOS, XIII, Belo Horizonte, 1999. Anais. [S.I.]: ABRH, 1999. 7p. 1 CD-ROM.

SPIRN, A. W. Enchentes, secas e águas poluídas. O jardim de granito - a natureza no desenho da cidade. São Paulo: Editora da Universidade de São Paulo, 1995. p,145-186. 
TASSI, R. Efeito dos microrreservatórios de lote sobre a macrodrenagem urbana, 2002. 142p. Dissertação (Mestrado) - Instituto de Pesquisas Hidráulicas, Universidade Federal do Rio Grande do Sul. Porto Alegre, 2002.

TUCCI, C. E. M.; PORTO, R. L.; BARROS, M. T.de (Org.) Drenagem urbana. 1.ed. Porto Alegre: ABRH/Editora da Universidade/UFRGS, 1995. 428p.

TUCCI, C. E. M. (Org.) Hidrologia: ciência e aplicação. 2.ed. Porto Alegre: Coleção ABRH de recursos hídricos, v.4, Editora da Universidade, 1997.

. Drenagem urbana. Ciência e Cultura, São Paulo, v.55, n.4, dez. 2003. Disponível em: <www.cienciacultura.bsv/scielo.php>. Acesso em: dez. 2004.

TUCCI, C.E.M.; MARQUES, D.M.L. DA M. (Org.) Avaliação e controle da drenagem. Porto Alegre: Editora da Universidade/UFRGS, 2000. v.1.

Avaliação e controle da drenagem Porto Alegre: Editora ABRH, 2001. v.2.

URBONAS, B. Assessment of Stormwater Best Management Practice Effectiveness, Inovative Urban Wet-Weather Flow Management Systems. USA: EPA, 1999. (EPA/600/R-99/029, chapter 7). Disponível em: <www.epa.gov/ORD/NRMRL/pubs>. Acesso em: nov. 2004.

URBONAS, B.; STAHRE, P. Stormwater best management practices and detention for water quality, drainage, and CSO management. New Jersey: Prentice Hall, Englewood Cliffs, 1993. 445p.

US EPA Preliminary data summary of urban storm water best management practices. Washington, DC: EPA, 1999. (EPA-821-R-99-012).

VIEIRA, A. R.; OLIVEIRA, R. Portugal, 2001. Qualidade da água e controlo da poluição de escorrências pluviais de infra-estrutura rodoviárias. Disponível em: 
<http://meteo.ist.utl.pt/ jjdd/LEAMB/LEAmb\%20TFC\%20site\%20v1/200_2001/Av ieira_Roliveira\%20artigo.pdf>. Acesso em: dez. 2004.

WANIELISTA, M. P. Volume and peak discharge management. Hydrology and Water Quality Control. New York: Wiley, 1990. p.375-443.

WILHEIM, J. Do Alicerce ao Teto. São Paulo: Textonovo Editora, 1998. 